\title{
Brook trout response to canopy and large woody debris manipulations in Appalachian streams
}

Jonathan Ma. Niles

West Virginia University

Follow this and additional works at: https://researchrepository.wvu.edu/etd

\section{Recommended Citation}

Niles, Jonathan Ma., "Brook trout response to canopy and large woody debris manipulations in Appalachian streams" (2010). Graduate Theses, Dissertations, and Problem Reports. 4637. https://researchrepository.wvu.edu/etd/4637

This Dissertation is protected by copyright and/or related rights. It has been brought to you by the The Research Repository @ WVU with permission from the rights-holder(s). You are free to use this Dissertation in any way that is permitted by the copyright and related rights legislation that applies to your use. For other uses you must obtain permission from the rights-holder(s) directly, unless additional rights are indicated by a Creative Commons license in the record and/ or on the work itself. This Dissertation has been accepted for inclusion in WVU Graduate Theses, Dissertations, and Problem Reports collection by an authorized administrator of The Research Repository @ WVU.

For more information, please contact researchrepository@mail.wvu.edu. 
Brook trout response to canopy and large woody debris manipulations in Appalachian streams.

\author{
Jonathan Ma. Niles
}

Dissertation submitted to the

Davis College of Agriculture, Natural Resources and Design

at West Virginia University

in partial fulfillment of the requirements

for the degree of

Doctor of Philosophy

In

Forest Resources Science

Kyle J. Hartman, Ph.D., Chair

Patrick Keyser, Ph.D.

Patricia Mazik, Ph.D.

J. Todd Petty, Ph.D.

Stuart Welsh, Ph.D.

Division of Forestry and Natural Resources

Morgantown, West Virginia

2010

Keywords: Riparian Zone, Timber Harvest, Stream Habitat, Brook Trout, Terrestrial Invertebrates, Trophic Dynamics

Copyright 2010 Jonathan M. Niles 


\section{ABSTRACT \\ Brook trout response to canopy and large woody debris manipulations in Appalachian streams}

Jonathan M. Niles

The forested riparian area along many central Appalachian streams contains large volumes of harvestable timber. Best management practices (BMP) and streamside management zones (SMZ) have been developed to minimize the impacts of riparian timber harvest. Large woody debris (LWD) is an important component of forested streams and its role in chemical, biological, and physical processes in streams is complex. The extraction of timber within the streamside management zone reduces the amount of material available for aquatic structure.

Three-250 m study reaches were established on eight Appalachian headwater streams. Four of the streams were assigned the treatment of having a 50\% basal area removal of SMZ timber and four were assigned a $90 \%$ basal area removal of SMZ timber. The down and up sections of each stream were then randomly assigned to be either basal area removal (removal) treatment or basal area removal plus instream LWD addition (removal + LWD) treatment, with reference sections located upstream of the treatment sections.

Pool habitat features changed substantially in all three sections, with variation between postharvest study years. However, pool area did not increase after the addition of LWD. Post-harvest stream temperature exhibited a constant pattern of increased warming as water moved downstream through the harvest zones. Mean maximum daily temperature downstream of timber harvest in $90 \%$ removal streams was an average of $3.1^{\circ} \mathrm{C}$ warmer than above harvest sections, and mean daily temperature was $1.1^{\circ} \mathrm{C}$ warmer. The $50 \%$ removal streams did not exhibit the large increases in stream warming seen in the $90 \%$ removal streams.

Seasonal population estimates of brook trout were conducted in 2005 (pre-treatment) 2007 and 2008 (post-treatment). Brook trout populations fluctuated over time, but did not show a consistent increase following treatment. Mean total length of YOY brook trout did vary across some streams and sections but was not significant among treatments. The condition $\left(\mathrm{W}_{\mathrm{r}}\right)$ of age $1+$ brook trout $(>120 \mathrm{~mm}$ ) did not differ between treatment and reference sections in $50 \%$ or $90 \%$ streams. Overall percent retention of resident fish differed significantly between sections. Percent immigration was high in all sections (60-71\%) suggesting high rates of movement.

Consumption estimates by origin of prey varied significantly within sections over the course of the study. Brook trout consumed a greater proportion of terrestrial invertebrates in reference sections than in timber removal sections during the study. Increased timber harvest intensity resulted in decreased consumption of terrestrial invertebrates by brook trout. Terrestrial invertebrates represent a greater proportion of the abundance, biomass and energy for brook trout in reference sites and may be greatly reduced in timbered areas. Brook trout in removal and reference sections exploited particular prey taxa at significantly different rates.

The results of our study show that it is necessary to assess trends in habitat changes, and brook trout populations over several years as there are several unknowns associated with the possible response to varying basal area removal. In addition, our study suggests that there could be changes in brook trout diet in the removal sections and a potential shift in the feeding habits of brook trout, and a reduction of terrestrial invertebrate availability to brook trout may result in decreased growth of Appalachian brook trout in these sections. 


\section{Dedication}

This work is dedicated to my parents George and Lynda Niles. It has been a long journey, thanks for the support and understanding. Good luck to my sister Meredith, as she begins work on her $\mathrm{PhD}$.

Secondly, this work is dedicated to my grandparents Raphel and Elizabeth Marconi whom both passed away while I was working on my master's degree but were so proud that their only grandson was working and living in West "By God" Virginia.

Lastly, this work is dedicated to Clayton and Mary Niles, who built the family cabin on Drew's Lake in Maine where I first learned to fish and developed an appreciation for the outdoors. It was those summers spent on the lake that eventually guided me into my chosen career. 


\section{Acknowledgements}

I would like to thank the MeadWestvaco Corporation, the U.S. Forest Service, the National Fish and Wildlife Foundation, West Virginia Department of Natural Resources, and the United States Forest Service for funding this research. The MeadWestvaco Corporation and Penn Virginia Corporation provided accommodations during the field season. I also thank the West Virginia University, Division of Forestry and Natural Resources for providing laboratory facilities used in the completion of this work, and for the teaching experience that I gained as under the Hoyt Teaching fellowship. I would like to thank the WVU Office of Graduate Education for the WVU Dissertation Finishing Grant that I received. I want to thank Dr. Jonathan Cumming for hiring me to teach Environmental Biology my final semester. I also want to sincerely thank my graduate committee members, Dr. Kyle Hartman, Dr. Pat Keyser, Dr. Pat Mazik, Dr. Todd Petty, and Dr. Stuart Welsh for their advice and guidance in the development of this research. I greatly appreciated Dr. Kyle Hartman for his guidance and willingness to have me as a graduate student under him for 2 degrees, and 8.5 years. His advice and guidance as an advisor, mentor, and friend have been invaluable. I greatly appreciate the help of fellow graduate students Ryan Utz, Garrett Staines, Andy Hafs, Ed McGinley, Brandon Keplinger, Jason Stolarski, and Jered Studinski who aided me in field and/or lab work. A special gratitude is owed to Brandon Keplinger who helped with dietary analysis and helped teach me how to identify terrestrial invertebrates and to Jered Studinski and Donna Hartman for helping with aquatic invertebrate identification and to Dr. John Sweka, Dr. George Merovich, Dr. Phil Turk, and Dr. Ryan Utz for their statistical help. I thank the following undergraduate work study students/volunteers who helped with field and/or lab work JD McComas, Bryan Olejacz, Andy Orsborne, Charlie Russell, Thomas Wilson, but particular thanks goes to Bryan "Butturs" Olejacz, and Charlie Russell, who helped me electroshock over the course of 2 years of work. I also want to thank research assistant John Howell for his efforts in the organization of field studies and support in all aspects of my graduate education. Thanks to Donna Hartman for treating me and all the grad students like one of the family. I finally want to thank all my friends (Andy, Charlie, Doug, Ed, Garrett, Jason, Jered, Ken, Murph, Phil, Proctor, Ryan, and Thorn) and family (Mom, Dad, Meredith, the Marconi's and Whitney's) for their support over the years of my graduate study. A final thanks to those WVU Rugby players that I had the privilege to coach over the last 5 years. I hope that as I leave WV, I made a positive difference in the lives of many people on the WVU campus. 
Table of Contents

Chapter 1. Introduction and Literature Review.................................................



Chapter 2. The Role of Riparian Timber Harvest and Large Woody Debris Additions in Structuring Stream Habitat and Thermal Regimes in Central Appalachian Streams......................................................... 20

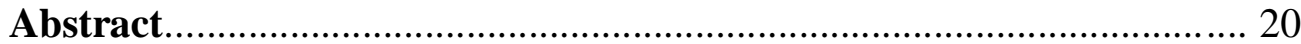

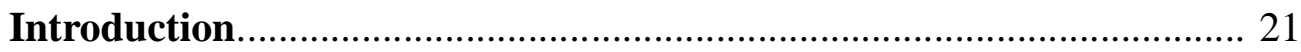





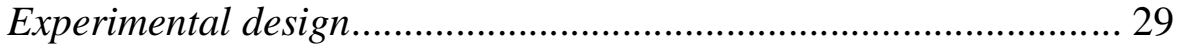

Habitat assessment ........................................................................... 30

Suspended sediment...................................................................... 32

Water quality and temperature ....................................................... 33

Riparian tree removal and Large Woody Debris additions...............34



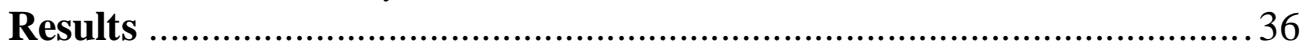

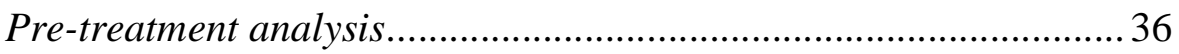

Riparian tree removal....................................................... 36

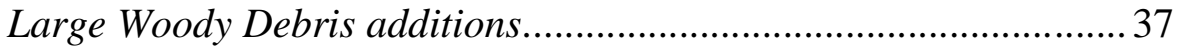

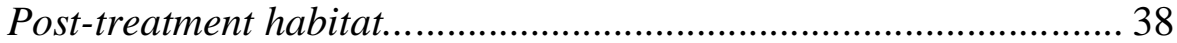

Temperature changes................................................................ 41

TSS and turbidity ................................................ 43

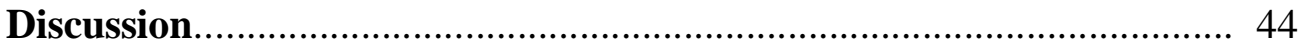



Temperature effects ...................................................................... 46

Downstream temperature recovery.............................................. 49

Temporal temperature recovery .................................... 50

TSS and turbidity................................................... 50

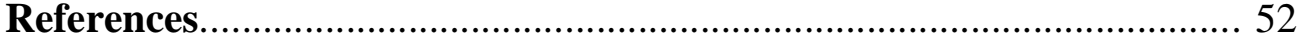

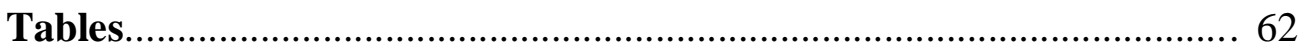

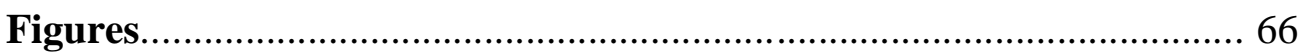

Chapter 3. The Role of Riparian Removal and Large Woody Debris Additions in Structuring Brook Trout Populations in Central Appalachian Streams...... 81

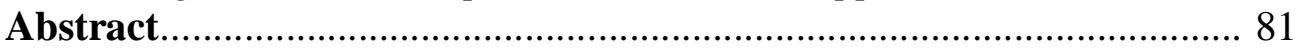

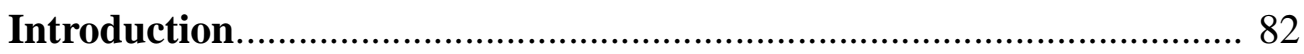

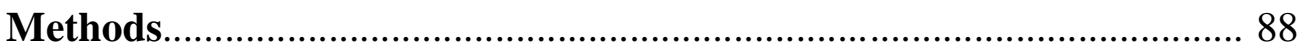

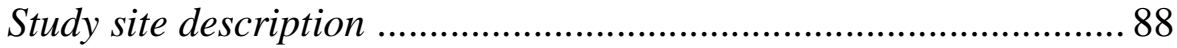

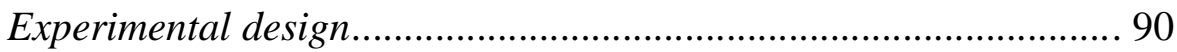

Habitat assessment ................................................................. 90

Riparian tree removal and LWD additions.................................. 92

Brook trout population estimates................................................. 93

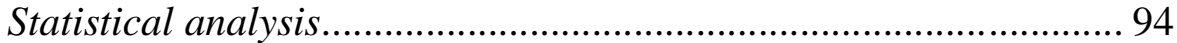

Brook trout populations..................................................... 94 


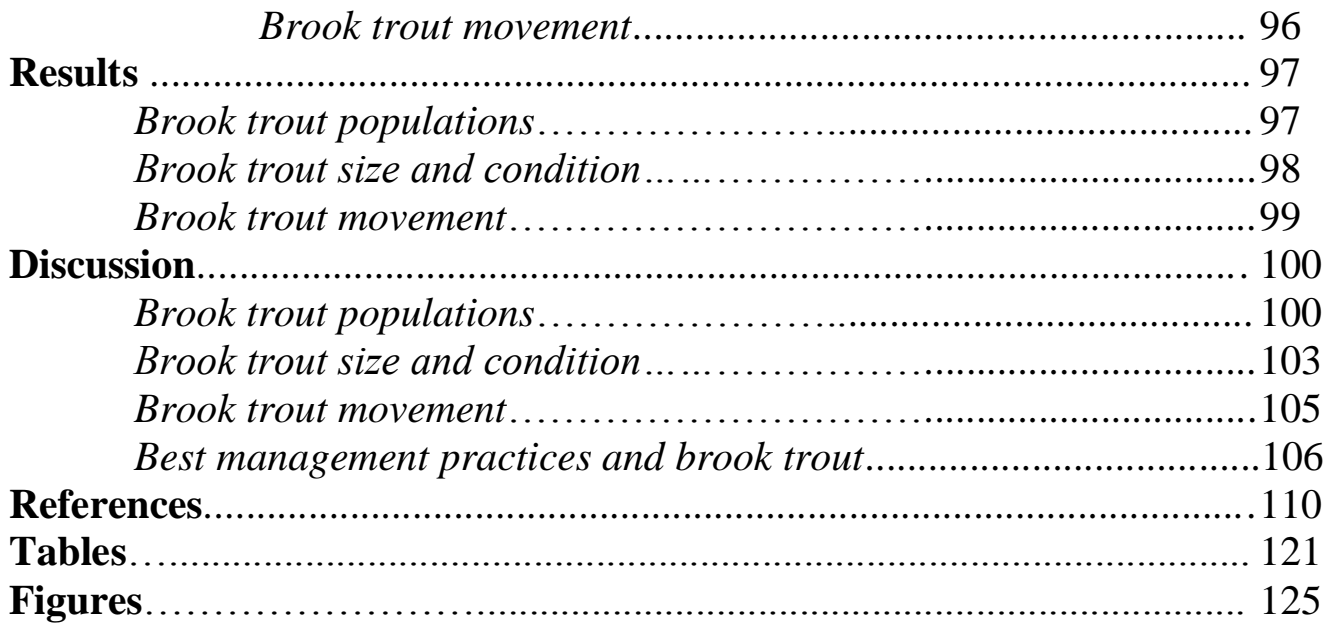

Chapter 4: Effects of riparian tree removal on Appalachian brook trout diet

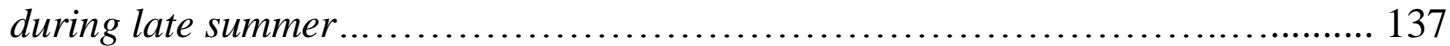

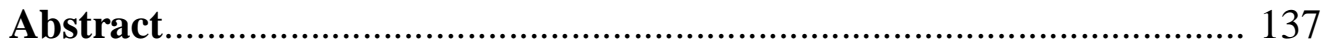

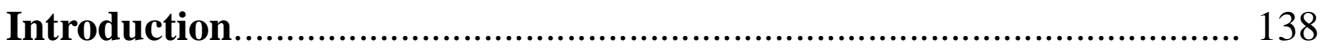



Study site description .......................................................... 141

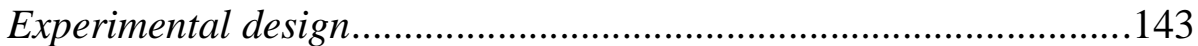

Riparian tree removal............................................................... 144

Terrestrial invertebrate inputs................................................... 144

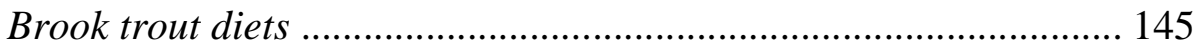

Laboratory procedures................................................... 146

Consumption and energy estimates............................................. 147

Statistical analysis....................................................................... 147

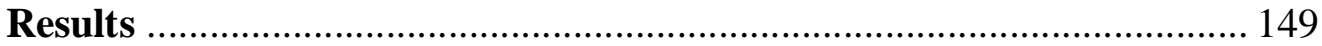

Effects of tree removal on invertebrates in brook trout diets............ 149

Proportional prey exploitation...................................................... 152

Terrestrial prey consumption vs. availability .......................... 153

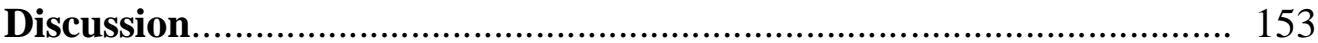

Effects of tree removal on invertebrates in brook trout diets............ 153

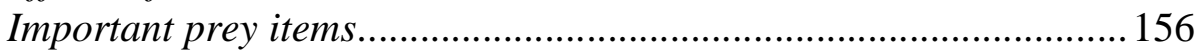

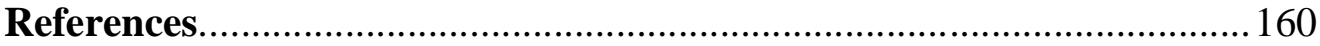



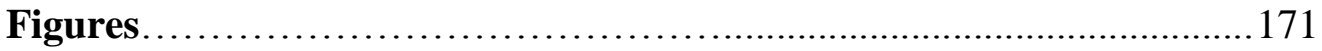

Chapter 5: Management Implication and Recommendation for Best Management

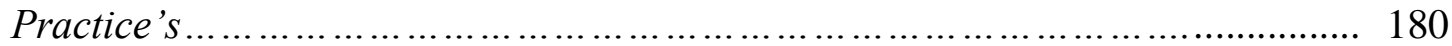

Riparian tree removal.................................................... 181

Large woody debris additions.................................. 185

Canopy cover, basal area, and slope .......................................... 188

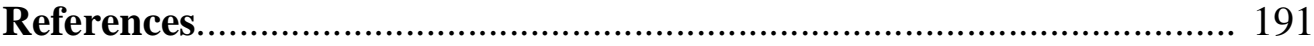

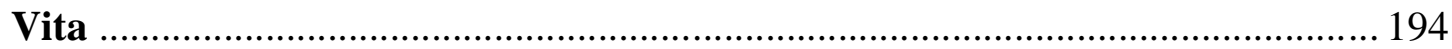




\section{Chapter 1. Introduction and Literature Review}

Forest cover influences numerous physical, chemical, and biological processes of stream ecosystems. Forest cover is an important controlling factor of stream hydrology (Dunne and Leopold 1978), and deforestation may result in altered stream baseflow and stormflow (Likens et al. 1970, Wright et al. 1990). Shifts in channel morphology and increased sediment yields often follow hydrologic alterations (Knighton 1998). Forest cover also influences stream water temperature through shading of the stream surface and by maintaining cool soil and air temperatures in both riparian and upland areas (Brosofske et al. 1997). Furthermore, forest cover affects stream nutrient budgets in temperate regions (Likens et al. 1970, Bolstad and Swank 1997).

Riparian forests have been defined in several different ways: 1) as ecotones between aquatic ecosystems and upland terrestrial ecosystems, 2) as distinct ecosystems that are delineated by the spatial extent of hydrologic influence from an adjacent water body, or 3) more broadly as corridors with proximity to stream channels that are the setting for a number of terrestrial-aquatic linkages (Malanson 1993). In undisturbed landscapes, riparian ecosystems are characterized by bi-directional interactions and mutual dependence of terrestrial and aquatic ecosystems (Nakano and Murakami 2001). In the past twenty years, riparian forests have been studied intensively due to recognition of their capacity to buffer streams from watershed land use disturbances. Riparian buffer is a term often used interchangeably with riparian ecosystem. However, buffer emphasizes a unidirectional interaction and the role that riparian zones play in protecting aquatic ecosystems from the effects of disturbed landscapes. It should be acknowledged that this term de-emphasizes the significance of riparian forests as unique 
terrestrial habitats that are in turn dependent upon adjacent aquatic ecosystems (Sanzone et al. 2003).

In addition to buffering freshwater ecosystems from watershed land use disturbances, riparian forests have a number of functions that support aquatic ecosystems. Riparian forests help control thermal regimes, input terrestrial organic matter, and stabilize instream habitat. In headwater streams, riparian forests form a canopy over the stream channel, reducing insolation and greatly impacting stream water temperature regimes. Riparian forests also impact stream thermal regimes by maintaining a thermal buffer of cool air and soil temperatures adjacent to streams (Brosofske et al. 1997). Consequently, streams with riparian forests are cooler and have less diel and seasonal fluctuation in temperature than pasture streams (Sweeney 1992, Chen and Chen 1994). Thermal functions of buffers are important because temperature affects water quality, ecosystem functions, and aquatic taxa that have narrow thermal tolerance ranges (Rutherford et al. 1997).

It has been argued that riparian buffers are one of the single most important factors affecting the integrity of aquatic ecosystems today (Sweeney 1992). Research has shown that riparian buffers in agricultural watersheds are highly effective at retaining sediment and nutrients in runoff from upland disturbance (Lowrance et al. 1997). In general, retention of sediment is a positive function of buffer width and a negative function of buffer hillslope (Wenger 1999). Longitudinal continuity of riparian buffers along stream corridors may also be required for effective sediment retention (Rabeni and Smale 1995). Sediment retention is an extremely important buffer function, considering the many detrimental ecological and economic effects of fine sediment in streams and rivers (Waters 1995). 
Riparian vegetation plays an important role in the biotic associations in streams (Cummins et al. 1984). Riparian vegetation influences the physical channel and allochthonous and autochthonous sources of organic inputs to the streams (Cummins et al. 1984, Hetrick et al. 1998a). Removal of the riparian overstory vegetation changes the trophic status of a stream from primarily allochthonous energy sources to primarily autochthonous energy sources (Cummins 1974, Minshall 1978). With removal of the canopy, light and water temperature usually increase and the input of nutrients may change (Cummins 1974). Other investigators have studied the effects of clear-cut logging on stream morphology (Toews and Moore 1982a), large and small organic debris inputs and processing (Toews and Moore 1982a, 1982b), macroinvertebrate communities (Newbold et al. 1980, Murphy and Hall 1981, Hawkins et al. 1983, Duncan and Brusven 1990), and fish communities (Sheridan and McNeil 1968, Burns 1972, Murphy and Hall 1981, Murphy et al. 1981, Hawkins et al. 1983, Heifetz et al. 1986, Johnson et al. 1986). Dolloff (1986) and Elliott (1986) evaluated the effects of stream cleaning after clear-cut logging on fish communities in small streams in southeast Alaska, and found that fewer juvenile salmonids were present in sections of streams that had woody debris removed than in streams with debris intact. Riparian logging can alter the biological, chemical, and physical processes and features that shape stream ecosystems and determine population density and community structure of salmonids (Gregory et al. 1987, Reeves et al. 1993). Because these processes and habitat features operate and vary at different time scales, the recovery of fish populations following riparian logging represents an integrative response to multiple habitat attributes that change through time (Gregory et al. 1987). For example, riparian canopy removal may increase stream temperature or primary productivity, resulting in an increase in juvenile salmonid density and growth during the summer (Bisson and Sedell 1984, Beschta et al. 1987, Bilby and Bisson 1992). 
Increases in salmonid productivity can be negated if temperature levels exceed thermal tolerances and may last only a few decades as the canopy closes and riparian-dependent habitat features (which operate at longer time scales and provide critical fish habitat) are degraded (Hall and Lantz 1969, Murphy and Koski 1989, Bilby and Ward 1991).

Instream physical habitat is dynamic and governed by the interaction of riparian vegetation, geomorphology and hydrology (Maddock 1999). Sweeney (1992) found that forested reaches of streams have significantly greater bankfull width, and thus greater benthic habitat than pasture reaches. Lammert and Allan (1999) showed that the percentage of pool habitat was positively related to riparian forest cover. In addition, instream habitat diversity, important to maintaining diverse aquatic assemblages, may be influenced by the length of upstream riparian forest patches (Jones et al. 1999).

Large woody debris (LWD) plays an important role in structuring the trophic dynamics of small streams. The abundance of LWD helps to define the degree of habitat complexity through the formation of pools (Berg et al. 1998, Dolloff 1986), creation of cover and refugia (Angermeier and Karr 1984), sorting and storage of sediment, and increasing bank stability (Shields 1998). Sweka (2006) found that when large woody debris was added to Appalachian streams new pools were formed, but overall pool area did not significantly increase. LWD can also influence stream trophic dynamics by increasing retention of organic matter (Smock et al. 1989, Raikow et al. 1995) which serves as substrate and food sources for macroinvertebrates. Allochthonous inputs are the main source of energy to small streams and debris dams are important for leaf litter processing and energy retention within the stream (Vannote et al. 1980, Raikow et al. 1995). Dams created by LWD also function as nutrient sinks as research has found that debris dams in first and second order streams contain 58 to $75 \%$ of the standing stock of 
organic matter (Bilby and Likens 1980). Debris dams decrease nutrient spiraling length in small streams and increase secondary production (Gurnell et al. 1995). Large woody debris also functions as an important invertebrate substrate and is quickly colonized (Angermeier and Karr 1984). Habitat created by LWD may comprise only a small portion of the available habitat, but can contribute the majority of the invertebrate biomass (Benke et al. 1984, Benke et al. 1985). Loss of large organic debris that enters streams is an additional effect of removing trees from riparian zones. Thus, LWD may influence all of the aforementioned key habitat components to the life cycle of stream fish.

Small stream habitats and energy processing are closely linked to the surrounding riparian zone. The riparian zone also supplies a direct energy source to stream fish in the form of terrestrial invertebrate input (Wipfli 1997, Nakano et al. 1999, Kawaguchi and Nakano 2001, Utz 2007) which supplements a fish's diet, especially during times of low aquatic invertebrate abundance. With the close linkage between terrestrial and aquatic environments in the riparian zone, anthropogenic disturbances along this ecotone have great potential to degrade stream habitat and productivity.

Old-growth forests are rare in the Appalachians. Streams that flow through old-growth forests exhibit higher nutrient levels and a greater abundance of LWD than streams flowing through second-growth forests (Silsbee and Larson 1983). The amount of LWD in small streams is related to the past landuse of the surrounding riparian area. The riparian forest surrounding many central Appalachian streams was destructively logged during the late $19_{\text {th }}$ and early 20 th century, which depleted much of the source of LWD (Flebbe and Dolloff 1995). The establishment of streamside management zones (SMZ) and use of best management practices (BMP) does much to minimize the impact of logging to stream systems (Davies and Nelson 
1994, Kochenderfer et al. 1997). Streamside management zones are now established to protect riparian vegetation and stream habitat. Streamside management zones limit timber harvest to approximately $50 \%$ of the basal area, thereby protecting the source of LWD, and prohibit the construction of roads running parallel to the stream thereby reducing sedimentation. However, it may be many more years before secondary growth within these SMZs can reach the age required to contribute LWD in amounts equivalent to those seen in old growth systems. Mature stands in the central Appalachians area are greater than 100 years old, and they may not begin to contribute LWD in amounts seen in old growth until they reach 150 - 200 years. Meanwhile, the lack of LWD has left streams with reduced habitat heterogeneity and productivity is reduced by decreased retention of organic matter. This could be a factor currently limiting stream fish production in the Appalachians.

Several studies have shown a positive correlation between salmonid abundance and the amount of large woody debris in streams. Berg et al. (1998) and Fausch and Northcote (1992) both found fish abundance was strongly correlated with total pool volume within a stream reach, which was governed by the amount of boulders and LWD in western streams. Rates of occupancy by salmonids in a given habitat type (e.g. pool, riffle, glide) increase with the amount of LWD (Flebbe and Dolloff 1995, Young 1996, Neumann and Wildman 2002). Flebbe and Dolloff (1995) warn that the response of trout to increased woody debris complexity cannot be determined by simply comparing trout density and biomass between streams and that manipulative study under controlled conditions are needed to conclusively determine the relationship between LWD, habitat, and trout. The extensive work by Fausch and colleagues, using habitat manipulation studies, found salmonid abundance increased in response to LWD addition in Colorado streams (Riley and Fausch 1995, Gowan et al. 1994, Gowan and Fausch 
1996a, Gowan and Fausch 1996b). However, they found high rates of fish movement and suggest that the observed increase in abundance was primarily due to increased immigration rather than increased survival. Several researchers reported increases in abundance of juvenile salmonids after clear-cut logging watersheds to the streambank (Johnson et al. 1986, Murphy et al. 1986, Thedinga et al. 1989); they attributed increases in abundance of fish to increases in abundance of prey that resulted from increased primary production. Murphy and Hall (1981) found increased biomass, density, and species richness of aquatic vertebrate and invertebrate predators in streams flowing through clear-cuts still exposed to sunlight when compared with similar old-growth stands; increases were greatest in small first-order streams. They also found that initial increases in production did not last as clear-cuts became reforested with secondgrowth red alder. In older clear-cut stream sections that had become shaded by deciduous forest canopy, biomass of salmonids and macroinvertebrate taxa were lower than in old-growth streams.

Conventional stream theory predicts that terrestrial subsidies, or allochthonous inputs, dominate the energy base of food webs in headwater streams where primary production is limited by shading (Vannote et al. 1980, Cummins et al. 1989). Allochthonous inputs are typically dominated by riparian leaf litter, but woody debris, coarse particulate organic matter (CPOM), fine particulate organic matter (FPOM), and dissolved organic matter (DOM) can also be substantial inputs (Webster et al. 1999). Long-term exclusion of terrestrial detritus from a headwater stream in the southern Appalachians highlighted the importance of terrestrial subsidies in supporting diverse stream communities. Reduced production of multiple trophic levels that followed exclusion of detritus demonstrated food web dependence on allochthonous inputs (Wallace et al. 1997). Food web tracer studies using stable isotopes have also 
documented the importance of terrestrial organic matter as a basal resource in undisturbed stream food webs (Bunn et al. 1989, Rosenfeld and Roff 1992). Stable isotope studies have demonstrated shifts from food web dependence on allochthonous detritus to greater utilization of instream autochthonous production when comparing forested stream reaches to pasture/grassland reaches (Rounick et al. 1982, Hicks 1997). Thus, riparian subsidies of headwater food webs may be important to stream ecosystem structure and function.

Although it is clear that riparian zones play a major role in regulating energy flow in loworder streams (Vannote et al. 1980), less is known of the trophic linkage that terrestrial invertebrates create between riparian and stream food webs, for example, terrestrial invertebrates serving as food for fishes (Wipfli 1997). Terrestrial invertebrates can comprise more than 50\% of energy intake by stream fishes and are often a preferred prey of juvenile salmonids (Hunt 1988). Nielsen (1992) found that terrestrially derived prey composed up to $28 \%$ of the total energy intake of juvenile coho salmon (Oncorhynchus kisutch) in Washington, whereas Wipfli (1997) reported that terrestrial prey composed over half of the biomass ingested by Dolly Varden char (Salvelinus malma), juvenile coho salmon, and cutthroat trout (Oncorhynchus clarki) in several southeastern Alaska streams. By constructing detailed annual budgets of terrestrial inputs and their consumption by salmonids, Kawaguchi and Nakano (2001) demonstrated that terrestrial invertebrates composed $53 \%$ of the annual prey consumption in a forested stream and $49 \%$ in a grassland stream. Terrestrial inputs were about twice as great in the forested stream than in the grassland stream, but their contribution to fish diet was virtually identical. Research in the Appalachians has shown that terrestrial prey organisms may play a large role in shaping Appalachian brook trout growth rates throughout certain times of the year (Cada et al. 1987, Ensign et al. 1991, Sweka 2003, Thorne 2004, Utz and Hartman 2007). 
Some evidence indicates that forest management, the species of riparian vegetation and canopy type can greatly influence terrestrial invertebrate abundance and may affect the amount of invertebrates that enter streams and fall prey to aquatic predators. Deciduous trees generally support more invertebrates than conifers (Southwood 1961). Clear-cutting decreased arthropod abundance the following year but increased their abundance the second year in North Carolina (Schowalter et al. 1981). Overhanging vegetation influenced terrestrial invertebrate input in some streams in Victoria, Australia, and terrestrial preys were more common in diets of fish from sites with overhanging vegetation (Cadwallader et al. 1980). Riparian forests with a substantial red alder (Alnus rubra) component may provide more terrestrially derived food for juvenile coho salmon, cutthroat trout, and Dolly Varden char than those riparian forests with only conifer (Wipfli 1997). Edwards and Huryn (1996) found that terrestrial invertebrates made only a small contribution to trout diet in a New Zealand pasture stream. If plant species or forest type influence terrestrial invertebrate communities, then riparian forest management will likely play a major role in regulating food resources for fishes, especially in small streams. Interestingly, the little research investigating the effects of timber harvest on inputs of terrestrial invertebrates into streams has failed to find significant relationships despite evidence that riparian vegetation composition affects terrestrial invertebrate communities (Allan et al. 2003, Musselwhite and Wipfli 2004).

The objective of the study was to examine aquatic-terrestrial linkages and how habitat and food resources influence populations of brook trout in central Appalachian streams. We conducted a set of manipulative experiments in streamside zones within forested watersheds in order to determine: (1) the effects of increased solar radiation on stream productivity, especially brook trout, and (2) the effects of increased solar radiation on water quality, and (3) the effects of 
increased large woody debris inputs on stream productivity, brook trout, and water quality, and (4) the effects of increased large woody debris inputs on instream habitat structure (pools). 


\section{References}

Allan, J. D., M. S. Wipfli, J. P. Caouette, A. Prussian, and J. Rodgers. 2003. Influence of streamside vegetation on inputs of terrestrial invertebrates to salmonid food webs. Canadian Journal of Fisheries and Aquatic Sciences 60:309-320.

Berg, N., A. Carlson, and D. Azuma. 1998. Function and dynamics of woody debris in stream reaches in the central Sierra Nevada California. Canadian Journal of Fisheries and Aquatic Sciences 55:1807-1820.

Bisson, P. A., and J. R. Sedell. 1984. Salmonid populations in streams in clear-cut vs. old-growth forests of western Washington. Pages 121-130 in W. R. Meehan, T. R. Merrell, Jr., and T. A. Hanley, editors. Proceedings, fish and wildlife relationships in old growth forests symposium. American Institute of Fishery Research Biologists, Asheville, North Carolina.

Benke, A. C., R. L. Henry, III, D. M. Gillespie, and R. J. Hunter. 1985. Importance of snag habitat for animal production in southeastern streams. Fisheries 10:8-13.

Benke, A. C., T. C. Van Arsdall, Jr., and D. M. Gillespie. 1984. Invertebrate productivity in a subtropical blackwater river: the importance of habitat and life history. Ecological Monographs 54:25-36.

Beschta, R. L., R. E. Bilby, G. W. Brown, L. B. Holtby, and T. D. Hofstra. 1987. Stream temperature and aquatic habitat: fisheries and forestry interactions. Pages 191-232 in E. O. Salo, and T. W. Cundy, editors. Streamside management: Forestry and fishery interactions. Institute of Forest Resources, University of Washington, Seattle.

Bilby, R. E., and P. A. Bisson. 1992. Allochthonous versus autochthonous organic matter contributions to the trophic support of fish populations in clear-cut and old-growth forested streams. Canadian Journal of Fisheries and Aquatic Sciences 49:540-551.

Bilby, R. E., and G. E. Likens. 1980. Importance of organic debris dams in the structure and function of stream ecosystems. Ecology 61:1107-1113.

Bilby, R. E., and J. W. Ward. 1991. Characteristics and function of large woody debris in streams draining old-growth clear-cut, and second-growth forests in southwestern Washington. Canadian Journal of Fisheries and Aquatic Sciences 48:2449-2508.

Bolstad, P. V., and W. T. Swank. 1997. Cumulative impacts of landuse on water quality in a southern Appalachian watershed. Journal of the American Water Resources Association 33:519-533.

Brosofske, K. D., J. Chen, R. J. Naiman, and J. F. Franklin. 1997. Harvesting effects on microclimatic gradients from small streams to uplands in western Washington. Ecological Applications 7:1188-1200. 
Bustard, D. R., and D. W. Narver. 1975a. Aspects of the winter ecology of juvenile coho salmon (Oncorhynchus kisutch) and steelhead trout (Salmo gairdneri). Journal of the Fisheries Research Board of Canada 32:667-680.

Bustard, D. R., and D. W. Narver. 1975b. Preferences of juvenile coho salmon (Oncorhynchus kisutch) and cutthroat trout (Salmo clarki) relative to simulated alteration of winter habitat. Journal of the Fisheries Research Board of Canada 32:681-687.

Bunn, S. E., D. R. Barton, H. B. N. Hynes, G. Power, and M. A. Pope. 1989. Stable isotope analysis of carbon flow in a tundra river system. Canadian Journal of Fisheries and Aquatic Sciences 46:1769-1775.

Burns, J. W. 1972. Some effects of logging and associated road construction on northern California streams. Transactions of the American Fisheries Society 101:1-17.

Cadwallader, P. L., A. K. Eden, and R. A. Hook. 1980. Role of streamside vegetation as a food source for Galaxias olidus Günther (Pisces: Galaxiidae). Australian Journal of Marine and Freshwater Research 31:257-262.

Chen D. Y., and H. Chen. 1993. Determining stream temperature changes caused by harvest of riparian vegetation: an overview. Pages 313-323. in: Riparian ecosystems in the humid U. S. functions, values and management. National Association of Conservation Districts, Washington, D.C.

Cummins, K. W. 1974. Structure and function of stream ecosystems. BioScience 24:631-641.

Cummins, K. W., G. W. Minshall, J. R. Sedell, C. E. Cushing, and R. C. Petersen. 1984. Mitteilungen der Internationalen Vereinigung fur Theoretische und Angewandte Limnologie 22:1818-1827.

Cummins K. W., M. A. Wilzbach, D. M. Gates, J. B. Perry, and W. B. Taliaferro. 1989. Shredders and riparian vegetation: leaf litter that falls into streams influences communities of stream invertebrates. BioScience 39:4-30.

Davies, P. E., and M. Nelson. 1994. Relationships between riparian buffer widths and the effects of logging on stream habitat, invertebrate community composition and fish abundance. Australian Journal of Marine and Freshwater Research 45:1289-1305.

Dolloff, C. A. 1986. Effects of stream cleaning on juvenile coho salmon and Dolly Varden in southeast Alaska. Transactions of the American Fisheries Society 115:743-755.

Duncan, W. F. A., and M. A. Brusven. 1990. Benthic macroinvertebrates in logged and unlogged low-order southeast Alaskan streams. Freshwater Invertebrate Biology 4:125-132. 
Dunne, T. and L. B. Leopold. 1978. Water in environmental planning. W. H. Freeman, New York.

Dunning, J. B., B. J. Danielson, and H. R. Pulliam. 1992. Ecological processes that affect populations in complex landscapes. Oikos 65:169-175.

Eaglin, G. S., and W. A. Hubert. 1993. Effects of logging and roads on substrate and trout in streams of the Medicine Bow National Forest, Wyoming. North American Journal of Fisheries Management 13:844-846.

Edwards, E. D., and A. D. Huryn. 1996. Effect of riparian land use on contributions of terrestrial invertebrates in streams. Hydrobiologia 337:151-157.

Elliott, S. T. 1986. Reduction of a Dolly Varden population and macrobenthos after removal of logging debris. Transactions of the American Fisheries Society 115:392-400.

Evans, B. F., C. R. Townsend, and T. A. Crowl. 1993. Distribution and abundance of coarse woody debris in some southern New Zealand stream from contrasting forest catchments. New Zealand Journal of Marine and Freshwater Research 27:227-239.

Fausch, K. D., and T. G. Northcote. 1992. Large woody debris and salmonid habitat in a small coastal British Columbia stream. Canadian Journal of Fisheries and Aquatic Sciences 49:682-693.

Flebbe, P. A., and C. A. Dolloff. 1995. Trout use of woody debris and habitat in Appalachian wilderness streams of North Carolina. North American Journal of Fisheries Management 15:579-590.

Gorman, O. T., and J. R. Karr. 1978. Habitat structure and stream fish communities. Ecology 59:507-515.

Gowan, C., and K. D. Fausch. 1996a. Long-term demographic responses of trout populations to habitat manipulation in six Colorado streams. Ecological Applications 6:931-946.

Gowan, C., and K. D. Fausch. 1996b. Mobile brook trout in two high-elevation Colorado streams: reevaluation of the concept of restricted movement. Canadian Journal of Fisheries and Aquatic Sciences 53:1370-1381.

Gregory, S. V., G. A. Lamberti, D. C. Erman, K. V. Koski, M. L. Murphy, and J. R. Sedell. 1987. Influence of forest practices on aquatic production. Pages 234-255 in E. O. Salo and T. W. Cundy, editors. Streamside management: forestry and fishery interactions. Proceedings of a Symposium. Institute of Forest Resources, University of Washington, Seattle. 
Gurnell, A. M., K. J. Gregory, and G. E. Petts. 1995. The role of coarse woody debris in forest aquatic habitats: implications for management. Aquatic Conservation: Marine and Freshwater Ecosystems 5:143-166.

Hall, J. D., and R. L. Lantz. 1969. Effects of logging on the habitat of coho salmon and cutthroat trout in coastal streams. Pages 355-375. in T. G. Northcote, Editor. Symposium on salmon and trout in streams. University of British Columbia, Vancouver.

Hawkins, C. P., M. L. Murphy, N. H. Anderson, and M. A. Wilzbach. 1983. Density of fish and salamanders in relation to riparian canopy and physical habitat in streams of the northwestern United States. Canadian Journal of Fisheries and Aquatic Sciences 40:11731185.

Heifetz, J., M. L. Murphy, and K. V. Koski. 1986. Effects of logging on winter habitat of juvenile salmonids in Alaska streams. North American Journal of Fisheries Management 6:52-58.

Hetrick, N. J., M. A. Brusven, W. R. Meehan, and T. C. Bjornn. 1998a. Changes in solar input, water temperature, periphyton accumulation, and allochthonous input and storage after canopy removal along two small salmon streams in southeast Alaska. Transactions of the American Fisheries Society 127:859-875.

Hetrick, N. J., M. A. Brusven, T. C. Bjornn, R. M. Keith, and W. R. Meehan. 1998b. Effects of canopy removal on invertebrates and diet of juvenile coho salmon in a small stream in southeast Alaska. Transactions of the American Fisheries Society 127:876-888.

Hicks, B. J. 1997. Food webs in forest and pasture streams in the Waikato region, New Zealand: a study based on analyses of stable isotopes of carbon and nitrogen, and fish gut contents. New Zealand Journal of Marine and Freshwater Research 31:651-664.

Hunt, R. L. 1988. A compendium of 45 trout stream habitat development evaluations in Wisconsin during 1953-1985. Wisconsin Department of Natural Resources Technical Bulletin 162: $80 \mathrm{p}$.

Johnson, S. W., J. Heifetz, and K. V. Koski. 1986. Effects of logging on the abundance and seasonal distribution of juvenile steelhead in some southeastern Alaska streams. North American Journal of Fisheries Management 6:532-537.

Jones, E. B., G. S. Helfman, J. O. Harper, and P. V. Bolstad. 1999. Effects of riparian forest removal on fish assemblages in southern Appalachian streams. Conservation Biology 13:1454-1465.

Kawaguchi, Y., and S. Nakano. 2001. Contribution of terrestrial invertebrates to the annual resource budget for salmonids in forest and grassland reaches of a headwater stream. Freshwater Biology 46:303-316. 
Kochenderfer, J. N., P. J. Edwards, and F. Wood. 1997. Hydrologic impacts of logging an Appalachian watershed using West Virginia's best management practices. Northern Journal of Applied Forestry 14:207-218.

Lammert, M., and J. D. Allan. 1999. Assessing biotic integrity of streams: effects of scale in measuring the influence of land use/cover and habitat structure on fish and macroinvertebrates. Environmental Management 23:257-270.

Lee, P., C. Smyth, and S. Boutin, 2004. Quantitative review of riparian buffer width guidelines from Canada to the United States. Journal of Environmental Management 70:165-180.

Likens, G. E., F. H. Bormann, N. M. Johnson, D. W. Fisher, and R. S. Pierce. 1970. Effects of forest cutting and herbicide treatment on nutrient budgets in the Hubbard Brook watershed-ecosystem. Ecological Monographs 40:24-47.

Lowrance, R., L. S. Altier, J. D. Newbold, R. R. Schnabel, P. M. Groffman, J. M. Denver, D. L. Correll, J. W. Gilliam, J. L. Robinson, R. B. Brinsfield, K. W. Staver, W. Lucas, and A. H. Todd. 1997. Water quality functions of riparian forest buffers in Chesapeake Bay watersheds. Environmental Management 21:687-712.

Maddock, I. 1999. The importance of physical habitat assessment for evaluating river health. Freshwater Biology 41:373-391.

Malanson, G. P. 1993. Riparian landscapes. Cambridge University Press, Cambridge.

Meehan, W. R. 1991. Influences of forest and rangeland management on salmonid fishes and their habitats, American Fisheries Society. Bethesda, Maryland.

Minshall, G.W. 1978. Autotrophy in stream ecosystems. BioScience 28:767-771.

Murphy, M. L., and J. D. Hall. 1981. Varied effects of clear-cut logging on predators and their habitat in small streams of the Cascade Mountains, Oregon. Canadian Journal of Fisheries and Aquatic Sciences 38:137-145.

Murphy, M. L., C. P. Hawkins, and N. H. Anderson. 1981. Effects of canopy modification and accumulated sediment on stream communities. Transactions of the American Fisheries Society 110:469-478.

Murphy, M. L., and K. V. Koski. 1989. Input and depletion of woody debris in Alaska streams and implications for streamside management. North American Journal of Fisheries Management 9:427-436.

Nakano, S., H. Miyasaka, and N. Kuhara. 1999. Terrestrial-aquatic linkages: Riparian arthropod inputs alter trophic cascades in a stream food web. Ecology 80:2435-2441. 
Nakano, S., and M. Murakami. 2001. Reciprocal subsidies: Dynamic interdependence between terrestrial and aquatic food webs. Proceedings of the National Academy of Sciences 98:166-170.

Neumann, R. M. and T. L. Wildman. 2002. Relationships between trout habitat use and woody debris in two southern New England streams. Ecology of Freshwater Fish 11:240-250.

Newbold, J. D., D. C. Erman, and K. B. Roby. 1980. Effects of logging on macroinvertebrates in streams with and without buffer strips. Canadian Journal of Fisheries and Aquatic Sciences 37:1076-1085.

Nielsen, J. L. 1992. Microhabitat-specific foraging behavior, diet, and growth of juvenile coho salmon. Transactions of the American Fisheries Society 121:617-634.

Rabeni, C. F., and M. A. Smale. 1995. Effects of siltation on stream fishes and the potential mitigating role of the buffering riparian zone. Microbiologia 303:211-219.

Raikow, D. F., S. A. Grubbs, and K. A. Cummins. 1995. Debris dam dynamics and coarse particulate matter retention in an Appalachian Mountain stream. Journal of the North American Benthological Society 14:535-546.

Ralph, S. C., G. C. Poole, L. L. Conquest, and R. J. Naiman. 1994. Stream channel morphology and woody debris in logged and unlogged basins of western Washington. Canadian Journal of Fisheries and Aquatic Sciences 51:37-51.

Reeves, G. R., F. H. Everest, and J. R. Sedell. 1993. Diversity of juvenile anadromous salmonid assemblages in coastal Oregon basins with different levels of timber harvest. Transactions of the American Fisheries Society 122:309-317.

Riley, S. C. and K. D. Fausch. 1995. Trout population response to habitat manipulation in six northern Colorado streams. Canadian Journal of Fisheries and Aquatic Sciences 52:3453.

Rosenfeld, J. S., and J. C. Roff . 1992. Examination of the carbon base in southern Ontario streams using stable isotopes. Journal of the North American Benthological Society 11:110.

Rounick J. S., M. J. Winterbourne, and G. L. Lyon. 1982. Differential utilization of allochthonous and autochthonous inputs by aquatic invertebrates in some New Zealand streams: a stable carbon isotope study. Oikos 39:191-198.

Rutherford, J. C., S. Blackett, C. Blackett, L. Saito, and R. J. Davies-Colley. 1997. Predicting the effects of shade on water temperature in small streams. New Zealand Journal of Marine and Freshwater Research 31:707-721. 
Sanzone, D. M., J. L. Meyer, E. Matri, E. P. Gardiner, J. L. Tank, and N. B. Grimm. 2003. Carbon and nitrogen transfer from a desert stream to riparian predators. Oecologia 134:238-250.

Schlosser, I. J. 1982. Fish community structure and function along two habitat gradients in a headwater stream. Ecological Monographs 52:395-414.

Schlosser, I. J. 1995. Critical landscape attributes that influence fish population dynamics in headwater streams. Hydrobiologia 303:71-81.

Schowalter, T. D., J. W. Webb, and D. A. J. Crossley. 1981. Community structure and nutrient content of canopy arthropods in clearcut and uncut forest ecosystems. Ecology 62:10101019.

Shields, F. D. 1998. Woody debris in river restoration: problems and opportunities. Water Resources Engineering 98:66-665.

Sheridan, W. L., and W. J. McNeil. 1968. Some effects of logging on two salmon streams in Alaska. Journal of Forestry 66:128-133.

Silsbee, D. G. and G. L. Larson. 1983. A comparison of streams in logged and unlogged areas of Great Smokey National Park. Hydrobiologia 102:99-111.

Smock, L. A., G. M. Metzler, and J. E. Gladden. 1989. Role of debris dams in the structure and functioning of low-gradient headwater streams. Ecology 70:764-775.

Southwood, T. R. E. 1961. The number of species of insect associated with various trees. Journal of Animal Ecology 30:1-8.

Swales, S., R. B. Lauzier, and C. D. Levings. 1986. Winter habitat preferences of juvenile salmonids in two interior rivers in British Columbia. Canadian Journal of Zoology 64:1506-1514.

Sweeney, B. W. 1992. Streamside forests and the physical, chemical, and trophic characteristics of piedmont streams in eastern North America. Water Science and Technology 26:26532673.

Sweka, J. A. 2003. Aquatic-terrestrial linkages in Appalachian streams: influence of riparian inputs on stream habitat, brook trout populations, and trophic dynamics. Ph.D. dissertation, West Virginia University, Morgantown.

Sweka. J. A. and K. J. Hartman. 2006. Effects of large woody debris addition on stream habitat and brook trout populations in Appalachian streams. Hydrobiologia 559:363-378.

Thedinga, J. F., M. L. Murphy, J. Heifetz, K. V. Koski, and S. W. Johnson. 1989. Effects of logging on size and age composition of juvenile coho salmon (Oncorhynchus kisutch) 
and density of presmolts in southeast Alaska streams. Canadian Journal of Fisheries and Aquatic Sciences 46:1383-1391.

Thorne, D. W. 2004. Spatial and seasonal variation in brook trout diet, growth, and consumption in a complex Appalachian watershed. Master's thesis, West Virginia University, Morgantown.

Toews, D. A. A., and M. K. Moore. 1989a. The effects of three streamside logging treatments on organic debris and channel morphology of Carnation Creek. Pages 129-153 in G. F. Hartman, editor. Proceedings of the Carnation Creek workshop: a ten-year review. Pacific Biological Station, Nanaimo, British Columbia.

Toews, D. A. A., and M. K. Moore. 1989b. The effects of streamside logging on large organic debris in Carnation Creek. Pacific Region Department of Fisheries and Oceans, Land Management Report 11, Vancouver, British Columbia.

Tschaplinski, P. J., and G. F. Hartman. 1983. Winter distribution of juvenile coho salmon (Oncorhynchus kisutch) before and after logging in Carnation Creek, British Columbia, and some implications for overwinter survival. Canadian Journal of Fisheries and Aquatic Sciences 40:452-461.

Utz, R. M. and K. J. Hartman. 2007. Identification of critical prey items to Appalachian brook trout (Salvelinus fontinalis) with emphasis on terrestrial organisms. Hydrobiologia 575:259-270.

Vannote, R. L., G. W. Minshall, K. W. Cummins, J. R. Sedell, and C. E. Cushing. 1980. The river continuum concept. Canadian Journal of Fisheries and Aquatic Sciences 37:130137.

Wallace, J. B., S. L. Eggert, J. L. Meyer, and J. R. Webster. 1997. Multiple trophic levels of a forest stream linked to terrestrial litter inputs. Science 277:102-104.

Waters, T. F. 1995. Sediment in streams: sources, biological effects, and control. American Fisheries Society, Bethesda, Maryland.

Webster, J. R., E. F. Benfield, T. P. Ehrman, M. A. Schaeffer, J. L. Tank, J. J. Hutchens, and D. J. D'Angelo. 1999. What happens to allochthonous material that falls into streams? A synthesis of new and published information from Coweeta. Freshwater Biology 41:687705.

Wenger, S. 1999. A review of the scientific literature on riparian buffer width, extent and vegetation. Office of Public Service \& Outreach, Institute of Ecology, University of Georgia, Athens. 
West Virginia Division of Forestry. 2005. WVDOF-TR-05-3. West Virginia silvicultural best management practices for controlling soil erosion and sedimentation from logging operations.

Wipfli, M. S. 1997. Terrestrial invertebrates as salmonid prey and nitrogen sources in streams: contrasting old-growth and young-growth riparian forests in southeastern Alaska, USA. Canadian Journal of Fisheries and Aquatic Sciences 54:1259-1269.

Wipfli, M. S. and J. Musselwhite. 2004. Density of red alder (Alnus rubra) in headwaters influences invertebrate and detritus subsidies to downstream fish habitats in Alaska. Hydrobiologia 520:153-163.

Wright, K. A., K. H. Sendek, R. M. Rice, and R. B. Thomas. 1990. Logging effects on streamflow: storm runoff at Caspar Creek in northwestern California. Water Resources Research 26:1657-1667.

Young, M. 1996. Summer movements and habitat use by Colorado River cutthroat trout (Oncorhynchus clarki pleuriticus) in small, montane streams. Canadian Journal of Fisheries and Aquatic Sciences 53:1403-1408. 
Chapter 2. The Role of Riparian Timber Harvest and Large Woody Debris Additions in Structuring Stream Habitat and Thermal Regimes in Central Appalachian Streams

\begin{abstract}
The forested riparian area along many central Appalachian streams contains large volumes of harvestable timber. Best management practices (BMP) and streamside management zones (SMZ) have been developed to minimize the impacts of riparian timber harvest. Large woody debris (LWD) is an important component of forested streams and its role in chemical, biological, and physical processes in streams is complex. The extraction of timber within the streamside management zone reduces the amount of material available for aquatic structure. Three-250 m study reaches were established on eight Appalachian headwater streams. Four of the streams were assigned the treatment of having a 50\% basal area removal of SMZ timber and four were assigned a $90 \%$ basal area removal of SMZ timber. The down and up sections of each stream were then randomly assigned to be either basal area removal treatment or basal area removal plus instream LWD addition treatment with reference sites located upstream of the treatment sections. Pool habitat features changed substantially in all three sections, with variation between post-harvest study years. Pool numbers in the LWD addition section decreased from 23 to 21 (-9\%) 1 year (2007) after the additions, then increased to $29(38 \%), 2$ years (2008) after the additions. The mean number of LWD pieces in streams increased within the LWD sections, but retention of LWD was poor in all stream sections as mean pieces of LWD decreased from year 1 (2007) to year 2 (2008). However, pool area did not increase after the addition of LWD. The inability of LWD additions to increase pool area may be due to the fact that the added LWD had not been in the streams long enough to become incorporated into the streambanks, and the majority of LWD additions were felled across the stream channel and were
\end{abstract}


hanging above the bankfull channel. The full potential of the added LWD to modify the stream channel morphology may not be realized for many more years. Post-harvest stream temperature exhibited a constant pattern of increased warming as water moved downstream through the harvest zones. Mean maximum daily temperature downstream of timber harvest in $90 \%$ removal streams was an average of $3.1^{\circ} \mathrm{C}$ warmer than above harvest sections, and mean daily temperature was $1.1{ }^{\circ} \mathrm{C}$ warmer. The $50 \%$ removal streams did not exhibit the large increases in stream warming seen in the $90 \%$ removal streams. In some $90 \%$ removal streams there was some temperature recovery as water flowed through the buffer zones. We suspect that the addition of large woody debris and tree tops played a significant role in mitigating the effect of riparian tree removal in our study.

\section{Introduction}

In the Southern Appalachians, many forests are relatively mature, but they lack the characteristics of an old growth forest. Streams flowing through previously logged secondgrowth forest differ from streams that drain old growth forests. In particular, many secondgrowth forest watersheds were logged at a time when the stream was cleared of woody debris to facilitate the downstream transport of timber (Dolloff 1994). In many of these watersheds, trees are not as old as those in old growth forests. The streams draining these forests lack the woody debris structure of streams that drain old growth watersheds (Bryant 1983, Silsbee and Larson 1983, Bisson et al. 1987, Murphy and Meehan 1991, Flebbe and Dolloff 1995).

Large woody debris (LWD) is an important component of forested streams and its role in chemical, biological, and physical processes in streams is complex. Large pieces of woody debris trap smaller organic particles (Naiman and Sedell 1979), and often form debris 
accumulation dams that regulate export (Bilby and Likens 1980) and decomposition (Reice 1974) rates of organic material. Large woody debris also retains transported sediment (Bilby and Ward 1989) and is important in the cycling of nutrients (Bilby and Likens 1980). Woody debris provides stable substrates for aquatic organisms such as bacteria (Triska et al. 1984), fungi (Shearer 1972), and invertebrates (Anderson et al. 1978, Benke et al. 1984, Sedell et al. 1988), all of which decompose wood and represent major components of the trophic food web of stream ecosystems by providing long-term food for aquatic organisms (Dudley and Anderson 1982).

Large woody debris plays an important role in structuring stream habitat. For example large pieces of woody debris are important determinants of channel morphometry in mountain streams (Heede 1972, Keller and Swanson 1979), and debris removal can cause dramatic changes in channel formation (Beschta 1979). Instream woody debris physically alters stream channel morphology creating areas of local channel scour and deposition (Beschta and Platts 1986, Fausch and Northcote 1992). Habitat for fish and aquatic organisms is created by woody debris altering channel morphology and through the dissipation of stream energy (Keller and Swanson 1979, Montgomery et al. 1995). Instream woody debris also plays critical roles in creating cover for fish (Tschaplinski and Hartman 1983).

The abundance of LWD helps to define the degree of habitat complexity through the creation of cover and refugia (Angermeier and Karr 1984), sorting and storage of sediment, increasing bank stability (Shields 1998), and the formation of pools (Berg et al. 1998). Hilderbrand et al. (1997) found that after LWD additions, pool area increased significantly in a low gradient (approximately 1\%) stream while it did not change in a high gradient (3-6\%) stream. They also noted that in the high gradient stream, some of the pools created by their LWD additions quickly reverted back to riffle habitat. In another Appalachian stream, Sweka 
and Hartman (2006) found that new pools were formed by the addition of LWD, but overall pool area did not increase significantly. The relatively high gradient of these streams may have precluded the added LWD from having a significant influence on stream channel morphology and habitat complexity (Sweka and Hartman 2006). Sweka and Hartman (2006) found that channel structure in Appalachian headwater streams was dynamic, and as new pools were created by LWD, other pools were lost. Additionally some of the pools created by the LWD were only temporary; forming one year and filling by the following year.

Numerous studies have shown positive correlations between salmonid abundance and the amount of pool habitat in streams. Fausch and Northcote (1992) and Berg et al. (1998) both found that fish abundance was strongly correlated with total pool volume within western streams, with pool volume influenced by the amount of boulders and LWD. Research has indicated salmonid abundance is positively related to pool area (Hunt 1971, Bowlby and Roff 1986). Occupancy rates by salmonids in a given habitat type (e.g. pool, riffle, glide) have been shown to increase with the amount of LWD present (Flebbe and Dolloff 1995, Young 1996, Neumann and Wildman 2002). Bonneau and Scarnecchia (1998) demonstrated a preference by bull (Salvelinus confluentus) and cutthroat (Oncorhynchus clarki) trout for pool habitats in high gradient (3-8\%) stream systems. Flebbe (1999) reported a preference of brook trout (Salvelinus fontinalis) for pool habitats in southern Appalachian stream systems. Hankin and Reeves (1988) and Herger et al. (1996) reported higher densities of salmonids in pools than in riffles. Hunt (1971) suggested the amount of pool habitat is an important component governing salmonid stream abundance. Trout density within pools can also be a function of the amount of cover present (Lewis 1969). Salmonids tend to be found in greater densities as instream cover improves (Wesche 1974, Fraley and Graham 1981, Bisson et al. 1982, Heifetz et al. 1986). In addition, during summer 
low flow conditions pool habitat is extremely important to salmonids. Salmonid carrying capacity has been suggested to be limited by habitat availability during summer low flow conditions (Elliot 1993, Lestelle et al. 1993). Elliot (2000) demonstrated deeper pool habitats maintained lower water temperatures and higher dissolved oxygen levels during drought periods than did shallower pools. Stream salmonids have been shown to seek pool areas during reduced flow conditions (Randolph and White 1984, Binns 1994, Huntingford et al. 1999, Elliot 2000). Hakala and Hartman (2004) found adult and YOY brook trout densities were $60 \%$ and $67 \%$ lower, respectively, after a drought period, with body condition also significantly lower. Kraft (1972) suggested the movement of brook trout into pools was in response to degrading habitat conditions.

The forested riparian area along many central Appalachian streams contains a large amount of harvestable timber. These riparian zones were clear-cut logged during the late $19^{\text {th }}$ and early $20^{\text {th }}$ century, thereby depleting much of the available source of large woody debris (Flebbe and Dolloff 1995). These timber harvests also cleared the stream channel of obstructions like boulders and large woody debris, thereby decreasing streambank stability and increasing sedimentation (Eaglin and Hubert 1993). These streams are now facing another wave of timber harvest as the forests again reach maturity. Due to the prevalence of headwater streams in West Virginia it is these riparian forests that are most likely to be harvested. Best management practices (BMP) and streamside management zones (SMZ) have been developed to minimize the impacts of riparian timber harvest. Within the U.S.A., actual guidelines and requirements vary by region and state (Lee et al. 2004). West Virginia BMP's require a SMZ that is at least $30 \mathrm{~m}$ wide (for perennial and intermittent streams) and is road-free (West Virginia Division of Forestry 2005). Streamside management zones in some states limit timber harvest to 
$<50 \%$ of the basal area, thereby protecting the source of large woody debris to the stream. In addition, West Virginia BMP's require felled tops in streams to be pulled from the stream channel on all perennial and intermittent streams to prevent bank erosion and channel blockage despite the fact that BMP guidelines state that large woody debris in the riparian areas and stream channels can be beneficial to aquatic life (West Virginia Division of Forestry 2005).

Logging debris refers to the tops, limbs, leaves, bark and non-merchantable logs or trees that might accumulate in lake or stream ecosystems as a consequence of a logging operation (Narver 1971). The accumulation of logging debris in rivers and lakes may yield structural as well as chemical changes in fish habitat (Narver 1971). The input of coarse (large branches, trees, etc.) and fine (small branches, leaves, needles, bark) woody debris is a natural process in forest ecosystems and plays an important role in providing fish habitat. Debris provides habitat structure both for predator and prey species seeking cover as well as a source of nutrients for lower trophic levels (Narver 1971). The extraction of timber may reduce the amount of material that may be available for aquatic structure. The accumulation of coarse and fine debris as a result of logging, however, may act to offset potential LWD input losses due to harvesting, and may improve existing habitat structure. Hicks et al. (1991) note that the potential benefits to fish include a short term increase in food production and survivorship resulting from increased organic matter and improved cover. The initial benefits imparted on fish habitat by debris inputs may, however, become overwhelmed by the negative impacts associated with high debris loading.

A number of physical changes accompany excessive debris inputs which may be detrimental to fish and fish habitat. Organic debris may fill the interstices of gravel and rubble, subsequently reducing the suitability of certain sites for spawning fish, and possibly smothering 
eggs and developing embryos (Narver 1971). In addition, coarse material may scour riverbanks and streambeds, consequently generating erosion and disrupting spawning habitat. Logging debris may impose a barrier to fish movement where high debris input has resulted in a 'log jam' (Narver 1971). Log jams are perhaps the most obvious manifestation of excessive debris. Although accumulations sufficient to prevent fish movement are rare, it is a problem that has emerged in coastal areas in Oregon and California (Merrell 1951, Holman and Evans 1964). Log jams are generally felt to be more likely where steep slopes encourage the entry of debris into associated water bodies (Narver 1971). Excessive debris inputs may alter the chemical environment in aquatic ecosystems. The breakdown of organic debris produces high biological oxygen demand (BOD) caused by the respiration of bacteria, fungi and protozoa (Narver 1971, Freedman 1989). Further, soluble organic substances, such as wood sugars which are leached from woody material exert a high chemical oxygen demand (COD). Reduced dissolved oxygen concentrations can adversely affect the swimming performance of juvenile and adult fish, may elicit avoidance reactions and halt migrations, may result in poor feeding behavior and in extreme cases, and cause mortality (Davis 1975, Bjornn and Reiser 1991).

The modification of water temperature in forested streams due to timber harvesting has been shown repeatedly in various forest landscapes. The most noticeable differences are generally observed in small, forested streams. Meehan et al. (1969) noted a maximum temperature increase of $5.0^{\circ} \mathrm{C}$ after logging in an Alaskan stream. Long term research from the Fernow Experimental Station in West Virginia showed that clear-cutting of a $20 \mathrm{~m}$ wide riparian strip and clearing of the stream channel raised stream temperatures as much as $7.8^{\circ} \mathrm{C}$ (Patric 1980). Work in Alberta by Nip (1991) showed an increase in July and August temperatures by $3.8^{\circ} \mathrm{C}$. When streamside vegetation was retained in the form of a buffer strip, temperatures for 
the same time period increased an average of only $1.8^{\circ} \mathrm{C}$ (Nip 1991). Brown and Krygier (1970) found no increases in temperature attributable to logging when buffer strips were maintained. Nicholson (1975) in studying boreal forests, found water temperatures showed a significant increase after logging. Increased water temperature due to logging is felt to be most noticeable in small streams bordered by tall, mature or over-mature forests.

Because all of these functions of streamside logging influence the quality of food and habitat resources available to fish, changes in the streamside zone and instream abundance of woody debris can be expected to induce changes in fish habitat. Depending on the magnitude of input, changes in fish habitat associated with streamside logging and instream logging debris may yield both positive and negative effects on fish populations in forested watersheds. This study seeks to investigate the ecological effects of riparian harvest at moderate and high intensities, the addition of LWD into streams, and the effects that these management techniques have on riparian canopy cover, instream habitat, and instream temperatures.

\section{Methods}

Study site description

This study was conducted in eight tributaries of the Middle Fork River, Randolph County, West Virginia. The watershed is located in the Allegheny Plateau physiographic province. The study streams were Birch Fork (BF), Kittle Creek (KC), Mitchell Lick (ML), Rocky Run (RR), Schoolcraft Run (SCR), Mulberry Fork (MF), South Fork Panther Run (SPR) and North Fork Panther Run (NPR) (Figure 1). All streams were small, low order, and relatively high gradient (Table 1). Stream elevations ranged from 685 to $929 \mathrm{~m}$. The pre-treatment percent canopy cover of these streams averaged $93 \%$, and stream temperatures remained adequate for 
brook trout for the majority of the year with temperatures rarely exceeding $20^{\circ} \mathrm{C}$. The surrounding watersheds of all streams were actively managed for fiber production by the MeadWestvaco Corporation (property was sold to Penn Virginia Corporation in fall 2007), and timber harvest activities occurred in all watersheds throughout the study. The age of the surrounding forest ranged from 65 to 85 years and was dominated by yellow birch (Betula alleghaniensis), yellow poplar (Liriodendron tulipifera), black birch (Betula lenta), and sugar maple (Acer saccharum). All riparian areas were logged in the past with the greatest logging activity occurring in the early 1900's and sporadically since the 1930's. Timber harvest followed West Virginia BMP's with harvest restricted to 50\% of the basal area of trees within SMZs. The width of the SMZs ranged from 15 to $50 \mathrm{~m}$ depending on slope with further guidelines that prohibit the operation of heavy machinery, and construction of logging roads. Instream crossings are permitted so long as the associated road enters and exits the SMZ in the shortest possible distance and a temporary culvert and sediment control devices are established (West Virginia Division of Forestry, 2005). Although limited harvest is permitted in SMZs, no such activity occurred along any of the study streams during the course of the study except where designated. Evidence of prior timber harvest (all > 10 years before start of study) was apparent along all the steams with the presence of abandoned logging roads and railroad grades, stream crossings, and eroded stream banks in some areas.

All streams have had limestone sand added annually by the West Virginia Department of Natural Resources and the West Virginia Department of Environmental Protection since the mid 1990's (WVDNR 2001). The underlying Pottsville geology has a very low buffering capacity; therefore limestone sand is added to mitigate the effects of acid precipitation and acid mine drainage in efforts to improve water quality in the mainstem of the Middle Fork River. 
Limestone is added by depositing a pile of sand on the streambank which is then swept into the stream under high flow events. This method of water quality enhancement has well documented success in elevating stream $\mathrm{pH}$, increasing macroinvertebrate abundance, and restoring fish communities in West Virginia streams (Clayton and Menendez 1998, Clayton et al. 1998, McClurg et al. 2007).

Typical of Appalachian headwater streams, fish species diversity was low in all of the streams in this study. Brook trout was the dominant species. Other species found included mottled sculpin (Cottus bairdi) and blacknose dace (Rhinichthys atratulus).

The study began in January 2005, as eight candidate streams were chosen from eighteen streams within the Middle Fork River watershed in consultation with the MeadWestvaco regional timberlands manager (Mr. Aaron Plaugher) and MeadWestvaco Wildlife Ecosystem Research Forest manager (Dr. Patrick Keyser). Treatment streams were ultimately chosen based on a similarity in the following criteria: geology, presence of instream liming, stream order, total stream length, slope, recent timber harvest activities, presence of brook trout, and access. During the summer of 2005 pre-harvest instream habitat measurements were taken. In July 2006 commercial timber harvests commenced in the SMZs of the 8 streams. Timber harvest was finished at 7 of the streams by November 2006. Harvest on one stream (Kittle Creek) was not completed until March 2007.

\section{Experimental design}

Three-250 m study reaches (designated down, up, and reference reaches according to their relative position along the stream gradient) were established on each of the 8 streams and these reaches were separated by $100 \mathrm{~m}$ buffers (Figure 2). Each stream was then randomly 
assigned treatment to a $50 \%$ or a $90 \%$ removal (basal area), which remained undisturbed throughout the study (Table 2). The down and up sections were then randomly assigned to be either basal area removal (removal) treatment or basal area removal plus instream LWD addition (removal + LWD) treatment. Reference sites were always located upstream of the treatment sections, to eliminate potential impacts of the treatments. There was not a "true" control stream without any habitat manipulation because stream to stream differences in habitat were greater than those within streams. The experiment was designed to determine if critical fish habitats such as pools, assessed by pool numbers, pool area, and temperature, increased in years following habitat manipulations.

\section{Habitat assessment}

Stream fish abundance has been shown to be related to physical habitat (Neumann and Wildman 2002, Warren and Kraft 2003) as well as water quality (Gagen et al. 1994, Nilslow and Lowe 2003) and as such, we sought to quantify these variables in our study. Habitat was surveyed during baseflow conditions according to a modified basinwide visual estimation technique BVET (Hankin and Reeves 1988, Dolloff et al. 1993, Simonson et al. 1994, Herger et al. 1996, Dolloff et al. 1997). Pre-harvest habitat data was assessed during baseflow conditions between 15 July and 30 July 2005. Post-harvest habitat data was assessed two times during baseflow conditions between 15 July and 2 August 2007, and again between 5 September and 15 2008. Individual habitat units were classified as pools, riffles, runs, or cascades according to criteria outlined in Arend (1999). Pools were considered areas of relatively low current velocity, greater depth, and laminar flow. Riffles were considered areas of lesser depth, greater current velocity, and broken water surfaces. Runs were considered areas where depth was shallower 
than pools; current velocity was greater than pools, but still maintained laminar flow and unbroken water surfaces. Cascades were considered areas with steep slope (> 7\%), high current velocity, and a stepped longitudinal profile, or areas that were a series of falls. If the habitat unit was a pool, the pool-forming mechanism was noted as boulder scour, LWD scour, bank scour, or freeform (Rosenfeld et al. 2000). Physical features measured in each habitat unit included length, wetted width, and water depths. The length of each habitat unit was measured along the thalweg (stream center) to the nearest $0.1 \mathrm{~m}$. Wetted and bankfull widths were visually estimated at transects established at $25 \%, 50 \%$, and $75 \%$ of the thalweg length. Depth was measured at three points along each transect to the nearest $\mathrm{cm}$. At every fifth habitat unit, the wetted and bankfull widths were both estimated and verified by measuring to the nearest $0.1 \mathrm{~m}$. The area of each habitat unit was estimated by multiplying the mean estimated wetted and/or bankfull width by its length. Estimated areas were then corrected by regression of verified area on estimated area and predicted values of the regression equation were used as the area of the habitat unit. Habitat unit areas were then summed by unit type to obtain an estimate of the total area of each unit type within each stream.

Several other habitat features were also inventoried within each basin. Percent canopy closure (Mills and Stevenson 1999) was estimated along the stream thalweg. In 2007, using benchmarks at the downstream reach of the study streams, canopy closure was estimated in each section with a digital camera (Model: Hewlett Packard, HP photosmart 850, t 7.6- 61mm) approximately every $50 \mathrm{~m}$ along the stream thalweg. At each point a picture $(25 \times 20 \mathrm{~cm})$ of the overhead canopy was taken with a digital camera (for records and count), with the camera fixed at a point $1 \mathrm{~m}$ off the ground. A 500 count grid $(1 \times 1 \mathrm{~cm})$ was then overlaid on the digital photo and percent of closed canopy cover was counted. An individual grid that had greater than 50\% 
coverage of trees or leaves was considered a closed canopy grid. An individual grid that had less than $50 \%$ coverage of trees or leaves was considered an open canopy grid.

Large woody debris was considered any piece of wood with at least a portion within the bank full channel that could be wet under bank full flows (Overton et al. 1997). All LWD was inventoried based on estimated diameter and length classes. The minimum size was defined as $10 \mathrm{~cm}$ diameter and $1 \mathrm{~m}$ length, to account for all woody debris which may be large enough to serve as structure in defining small stream morphology (Richmond and Fausch 1995).

\section{Suspended sediment}

We developed a Total Suspended Solids (TSS) - turbidity curve to allow us to predict TSS in each stream from turbidity and discharge measures (Sanders 2004). To evaluate the effect of SMZ manipulation intensity upon TSS and deposited sediment, we measured these variables above and below each treatment reach on our streams. Suspended sediments were sampled opportunistically following rainfall events and during normal flow conditions associated with other sampling activities during summer 2007 and 2008. Turbidity (nephelometric turbidity units, or NTUs) was measured with a LaMotte (Model 2020e) turbidity meter $( \pm 0.05$ NTU). One liter water samples were collected mid-stream and at a consistent rate from the surface to the bed and back to the surface (Beschta 1996). Water samples were filtered through pre-weighed glass fiber filters (pore size: $0.7 \mu \mathrm{m}$ ). The filters were then dried at $105^{\circ} \mathrm{C}$ in an Isotemp oven for 24 hours and then weighed to the nearest $\pm 0.0001 \mathrm{mg}$ (Beschta 1996). Turbidity measurements also were taken with a concurrent discharge measurement in order to calculate TSS loads of each of the study streams (Beschta 1996). Discharge was taken at 60\% depth using a flow staff and a digital flow meter, in ten equal cells in a cross-section of the stream (Bain 1999). 


\section{Water quality and temperature}

Water quality was measured periodically throughout the four year study duration during all seasons. We used a YSI® hand held meter (Model 600R) to measure dissolved oxygen, pH, temperature, and specific conductivity. Temperature loggers (Hobo ® Water Temp Pro), were deployed at locations in each stream to record post harvest hourly temperature measurements from 6 April 2007 thru 25 October 2008 (dates varied by stream). To minimize potential for heating by solar radiation absorption, the loggers were housed in polyvinyl chloride (PVC) pipe with multiple holes drilled through to promote water exchange, and all were placed in shaded locations (below undercut banks or large wood). Temperatures were recorded every $1 \mathrm{~h}$ and were averaged within days to generate daily maximum and mean temperatures in each stream. Several temperature loggers were lost during the first year of the post-harvest and because of this we were only able to make year 1 post-treatment comparisons between the three sections on South Branch Panther, the $90 \%$ basal area removal and reference section of Mitchell, the 50\% removal and LWD addition section of North Panther, and the 90\% removal and LWD addition section of Schoolcraft. In 2008, we redeployed temperature loggers in the streams in a different array. We deployed temperature loggers in 5 locations ( $0 \mathrm{~m}$ down, $250 \mathrm{~m}$ down, $0 \mathrm{~m}$ up, $250 \mathrm{~m}$ up, and $150 \mathrm{~m}$ reference) in each stream (Figure 2). We placed the temperature logger at the 150 $\mathrm{m}$ mark of the reference section to estimate the amount of natural stream warming in $250 \mathrm{~m}$ of stream (150 m reference plus $100 \mathrm{~m}$ buffer). We deployed the temperature loggers in two batches due to a limited amount of loggers: the loggers were deployed on the following streams from 18 June 2008 thru 27 July 2008; Birch Fork, Kittle Creek, Mitchell Lick, and Rocky Run. The temperature loggers were then removed from each stream, the data downloaded and then 
redeployed in the same array from 5 August 2008 to 25 October 2008 on the remaining streams; Schoolcraft Run, North Panther Run, Mulberry Run, and South Panther Run.

\section{Riparian tree removal and LWD additions}

Riparian tree removal and large woody debris additions began in July 2006 by 3 separate crews of loggers. Each logging crew was instructed to harvest trees within the SMZ as they normally would at any other site while abiding by WV Forestry BMPs. All trees felled within the removal only section were removed from the stream channel after harvesting. In the large woody debris addition section each logging crew was instructed to target 40 trees for felling in each reach. The trees selected for felling were spaced approximately every $15 \mathrm{~m}$ of stream. Loggers felled one tree on each side of the stream with the hope that the two trees would anchor themselves to one another and create debris dams. Felled trees were selected based on size (> 10 $\mathrm{cm} \mathrm{dbh),} \mathrm{and} \mathrm{by} \mathrm{the} \mathrm{ease} \mathrm{with} \mathrm{which} \mathrm{the} \mathrm{loggers} \mathrm{could} \mathrm{fell} \mathrm{the} \mathrm{tree} \mathrm{into} \mathrm{the} \mathrm{stream} \mathrm{channel.} \mathrm{In}$ the large woody debris addition section, tree tops and branches that fell into the streams during harvest were left in place, so that they could create debris dams. Unlike previous studies, felled trees were not bucked so that the tree came in contact with the stream bed (Sweka 2003). The purpose of this study was to determine if normal timber harvesting techniques were able to increase instream habitat and productivity, as such we did not want extra time and effort spent by logging crews bucking logs as they normally would not do so during the course of typical riparian tree harvest. 


\section{Statistical analysis}

We tested several hypotheses concerning the added large woody debris. The initial number and volume of LWD prior to treatment application was compared between the 50\% and 90\% streams using a one-way analysis of variance (ANOVA) with stream sections as replicates. A repeated measures analysis of variance with the streams as the subject and the two scales of harvest as the treatment was used to determine if the number of pieces and volume of LWD increased over time and if there was a difference between stream sections (ANOVA; PROC MIXED SAS® version 9.1).

Initial numbers of pools, mean pool length $(\mathrm{m})$, mean pool area $\left(\mathrm{m}^{2}\right)$, and mean percent pool area between sections on each stream were compared using an analysis of variance. Following removal and large woody debris additions, we used analysis of variance with the treatment effect of percent basal area removal as the subject to determine if there was a difference in mean number of pools, mean pool length, and mean pool area $\left(\mathrm{m}^{2}\right)$ for stream sections between years. In 2007, post treatment percentage canopy closure was compared on each stream within treatment sites using two-sample paired t-tests to determine changes in canopy cover from reference conditions.

To determine whether SMZ harvest affected mean or maximum summer stream temperatures, we contrasted stream sections after logging (2008) with a maximum likelihood using analysis of variance (ANOVA; PROC MIXED, SAS version 9.1). For the purposes of determining summer stream temperature differences, we used two separate 40-day periods for analysis (Period 1: 18 June to 27 July, Period 2: 5 August to 13 September). The model included the main effects of treatment (50\% or 90\% basal area removal), sections within treatment, and the interaction between treatment and sections. Post hoc treatment effects were analyzed using 
LSM. To determine if there were differences in mean turbidity and sediment load between the reference and treatment sections we used t-tests.

\section{Results}

Pre-treatment analysis

Prior to habitat manipulation we analyzed several habitat metrics to determine if stream sections had equivalent pool habitat. Prior to timbering, the number of pools $(\mathrm{p}=0.530)$, total pool length $(\mathrm{p}=0.586)$, mean pool area $(\mathrm{p}=0.541)$, and total pool area $(\mathrm{p}=0.909)$ per stream section were not different between streams (Table 2).

\section{Riparian tree removal}

Canopy closure was variable across our treatments post harvest. Following harvest, mean canopy closure of the 50\% treatment group was $83.4 \%$ in the removal and $85.1 \%$ in the removal + LWD sections (Figure 3). After harvest mean canopy closure in the $90 \%$ removal treatment was $39.8 \%$ in the removal and $38.2 \%$ in the removal + LWD addition section (Figure 4). Removal of $90 \%$ of the streamside basal area was not achieved in some locations because loggers left residual trees where soil and slope conditions would have resulted in compromising the stream bank or slope.

Individual streams varied in post-harvest percent canopy closure between harvested sections and reference sections (Table 3). In one 90\% removal stream, canopy closure was reduced to $20.2 \%$ in the R + LWD section and $18.1 \%$ in the removal section while another $90 \%$ removal stream had canopy closure of $67.6 \%$ and $57.8 \%$ respectively in the removal and removal + LWD sections. 


\section{LWD additions}

Prior to habitat manipulation the number of pieces of LWD per $250 \mathrm{~m}$ stream reach was not significantly different between the $50 \%$ and $90 \%$ removal streams $(\mathrm{p}=0.233)$ or volume $(\mathrm{p}=$ 0.382). The numbers of pieces of LWD per $250 \mathrm{~m}$ stream reach averaged 108.2 in the $50 \%$ removal streams and 135.0 in $90 \%$ removal streams (Figure 5). The volume of LWD per $250 \mathrm{~m}$ stream reach averaged $58.2 \mathrm{~m}^{3}$ in the $50 \%$ removal streams and $63.5 \mathrm{~m}^{3}$ in $90 \%$ removal streams (Figure 6).

Following logging the number and volume of LWD in removal + LWD addition sections of streams increased while LWD volume decreased in reference sections. The summer after logging and LWD addition (2007), the mean number of LWD pieces in 50\% removal streams increased to $231.0(119 \%)$ in the removal + LWD sections $(p=0.004$, Figure 5). In 2007, the mean volume of LWD in 50\% removal streams increased to $91.3 \mathrm{~m}^{3}(56 \%)(\mathrm{p}=0.049$, Figure 6). We found similar trends in the $90 \%$ removal streams as the mean number of LWD pieces in 2007 increased to $305.3(91 \%)$ in the removal + LWD sections $(\mathrm{p}=0.030)$ (Figure 5). The mean volume of LWD increased to $107.0 \mathrm{~m}^{3}(41 \%)$ in the removal + LWD sections $(\mathrm{p}=0.477$, Figure 6). In the year after logging and LWD addition, we found small increases of the number of pieces of LWD in the removal sections in both the $50 \%$ and $90 \%$ removal streams. These pieces were likely small logging slash that were moved into the bankfull channel during high flows. Mean volume of LWD decreased in the removal section in both $50 \%$ and $90 \%$ treatments in 2007. Both the 50\% and $90 \%$ reference sections had decreases in mean pieces and volume of LWD.

Retention of LWD was poor in all stream sections as mean pieces of LWD decreased from 2007 to 2008. The mean number of LWD pieces in $50 \%$ removal streams decreased to 
$168.5(-37 \%)$ in the removal + LWD sections ( $\mathrm{p}=0.205$, Figure 5). The mean volume of LWD decreased to $35.9 \mathrm{~m}^{3}(-154 \%)(\mathrm{p}=0.010$, Figure 6). We found similar trends in the $90 \%$ removal streams as the mean number of LWD pieces decreased to $241.3(-27 \%)$ in the removal + LWD sections ( $\mathrm{p}=0.642$, Figure 5). The mean volume of LWD decreased to $58.4 \mathrm{~m}^{3}(-83 \%)$ in the removal + LWD sections in $2008(p=0.166$, Figure 6). The mean number of LWD pieces in reference sections in both $50 \%$ and $90 \%$ removal streams decreased from 2005 to 2008 (Figure 5). The mean volume of LWD in reference sections decreased from 2005 to 2008 in both $50 \%$ and $90 \%$ removal streams (Figure 6).

\section{Post-treatment habitat}

In the $50 \%$ removal streams, pool habitat features changed substantially in all three sections, with variations between post harvest study years. Pool numbers in the removal + LWD section decreased from 23 to $21(-9 \%)$ one year after the additions, then increased to 29 (38\%), two years after the additions. Pool numbers substantially decreased in the other two sections, decreasing from 32 to 23 (2007) and 22 (2008) in the removal and from 26 to 20 (2007) and 19 (2008) in the reference section (Table 4). Analysis of the 50\% basal area removal sections found no significant differences in the number of pools between years for stream sections. All new pools created in the removal + LWD addition section were caused by the addition of LWD or tree tops. Mean pool length decreased in all sections from 2005 to 2007, but increased in the removal + LWD section in $2008(33 \%)$. Analysis of the $50 \%$ basal area removal sections found no significant differences in the mean pool length between years for stream sections. Mean pool area in the removal + LWD section decreased from 2005 to 2007 (-31\%), and then increased in 2008 (18\%). Mean pool area declined in the other two stream sections. Mean pool area 
decreased from $125.0 \mathrm{~m}^{2}$ to $101.6 \mathrm{~m}^{2}$ (2007) and $86.9 \mathrm{~m}^{2}$ (2008) in the removal section, and from $314.2 \mathrm{~m}^{2}$ to $268 \mathrm{~m}^{2}$ (2007) and $260.5 \mathrm{~m}^{2}$ (2008) in the reference section (Table 4). Analysis of the $50 \%$ basal area removal sections found no significant differences in the mean pool area between years for stream sections. Total pool area in the removal + LWD sections decreased from 2005 to 2007 (-28\%), and then increased in 2008 (24\%). Total pool area declined in the other two stream sections, decreasing in both 2007 and 2008 in the removal section and the reference section (Table 4).

Total stream area occupied by pools in the $50 \%$ removal streams decreased most dramatically in the removal and reference sections. The removal + LWD section decreased post harvest year one and then increased in year post-harvest year two. Percent stream area as pools increased from $15.9 \%$ to $16.4 \%$ by the end of the study in the removal + LWD section, however total pool area was still less than the start of the study (Table 4).

In the $90 \%$ removal streams, pool habitat features changed substantially in all three sections, with variation between post harvest study years. Pool numbers in the removal + LWD section increased from 25 to $31(24 \%)$ one year after the additions, then decreased to $29(-7 \%)$, two years after the additions. Pool numbers varied substantially in the removal sections, increasing from 28 to 33 (2007) and decreasing to 27 (2008). Pool numbers decreased in the reference section from 27 to 24 (2007 and 2008) (Table 4). Analysis of the 90\% basal area removal sections found no significant differences in the number of pools between stream sections. All new pools in the removal + LWD section were caused by the addition of LWD or tree tops. New pools created in the removal section were from logging debris being moved into the stream creating pools. 
Mean pool length varied all sections from 2005 to 2007, with increases in the removal section $(12 \%)$, and decreases in the removal + LWD (-6\%) and reference sections $(-13 \%)$. Mean pool length decreased across all stream sections in 2008 (Table 4). Analysis of the $90 \%$ basal area removal sections found no significant differences in the mean pool length between years for stream sections. Mean pool area in the removal section increased from 2005 to 2007 (3\%), and then decreased in $2008(-37 \%)$. Mean pool area declined in the other two stream sections in 2007, decreasing from $144.3 \mathrm{~m}^{2}$ to $128.5 \mathrm{~m}^{2}$ in the removal + LWD section and from $129.9 \mathrm{~m}^{2}$ to 103.4 $\mathrm{m}^{2}$ in the reference section (Table 4). Mean pool area decreased in the removal + LWD section in 2008 , decreasing to $88.5 \mathrm{~m}^{2}$, but increased in the reference section from $113.2 \mathrm{~m}^{2}$ (Table 4). Analysis of the $90 \%$ basal area removal sections found no significant differences in the mean pool area between years for stream sections. Total pool area in the removal + LWD section decreased in both $2007(-11 \%)$ and 2008 (31\%). Total pool area was variable for both post harvest years in the other two stream sections. Total pool area increased in 2007 (3\%), then decreased in $2008(-37 \%)$ in the removal section. Total pool area decreased in $2007(-20 \%)$, then increased in 2008 (10\%) in the reference section (Table 4). Total stream area occupied by pools in the $50 \%$ removal streams decreased most dramatically in the removal + LWD addition and removal sections. The reference section had the percent pool area decrease post harvest year one and then increase in post harvest year two.

Individual streams varied in their pool habitat and characteristics with the largest changes in the $90 \%$ removal streams. Rocky Run had the most variation among the $90 \%$ removal streams, with the differences being attributed to blowout or filling in of large pools between November 2006 and March 2007. In 2007 the removal + LWD section of Rocky Run had 2 more pools than in 2005. However, these were two small pools ( 2 and $3 \mathrm{~m}$ long) with a 
combined pool area of $13 \mathrm{~m}^{2}$. During the same period of time the removal + LWD section had the two longest $(18.5$ and $9.5 \mathrm{~m})$ and largest pools $\left(132 \mathrm{~m}^{2}\right)$ decrease in area to $18 \mathrm{~m}^{2}$ due to sedimentation. Similar effects were seen downstream as the two largest pools (12.8 and $13.4 \mathrm{~m})$ in the removal section were reduced in pool area from $133 \mathrm{~m}^{2}$ to $44 \mathrm{~m}^{2}$. The three other $90 \%$ removal streams each had an increase in total pool area in both the removal + LWD $\left(38 \mathrm{~m}^{2}\right)$ and removal sections $\left(171 \mathrm{~m}^{2}\right)$. Rocky Run was the only stream in the study to begin carving a new channel. Sometime after harvest a large flood allowed Rocky Run to run down a nearby old skidder road for approximately $50 \mathrm{~m}$ carving a new channel until it rejoined the mainstem of the stream. Approximately $1 / 3$ of the stream flowed down this skid road during normal baseflow conditions.

\section{Temperature changes}

Post-harvest stream temperature exhibited a pattern of increased warming as water moved downstream thru the harvest zones. During the first temperature profile period (18 June to 27 July 2008), mean maximum daily temperature at the $0 \mathrm{~m}$ down station was $3.1^{\circ} \mathrm{C}$ warmer than the reference stations in $90 \%$ removal streams (Figure 7). Maximum daily temperature reached a high of $22.7^{\circ} \mathrm{C}$ on 19 July in the $0 \mathrm{~m}$ down station in the $90 \%$ removal streams. Mean daily temperatures also had a similar pattern of increased warming downstream during the first temperature profile period in $90 \%$ removal streams. Mean daily temperature at the $0 \mathrm{~m}$ down station was $1.1^{\circ} \mathrm{C}$ warmer than the reference station for $90 \%$ removal streams during this period (Figure 8). Mean daily temperature peaked at $19.5^{\circ} \mathrm{C}$ on 21 July at the $250 \mathrm{~m}$ down station for $90 \%$ removal streams. 
The $50 \%$ removal streams did not exhibit the large increases in stream warming seen in the $90 \%$ removal streams during the first temperature profile. During the first temperature profile period, mean maximum daily temperature for at the $0 \mathrm{~m}$ down station was $0.6^{\circ} \mathrm{C}$ warmer than the reference station (Figure 9). Maximum daily temperature reached a high of $19.4^{\circ} \mathrm{C}$ on 21 July in the $0 \mathrm{~m}$ down station in the $50 \%$ removal streams. Mean daily temperatures also had minimal increases in temperature during this profile period. Mean daily temperature at the $0 \mathrm{~m}$ down station was $0.4^{\circ} \mathrm{C}$ warmer than the reference station in the $50 \%$ removal streams during this period (Figure 10). Mean daily temperature peaked at $18.1^{\circ} \mathrm{C}$ on 21 July at the $0 \mathrm{~m}$ down station for $50 \%$ removal streams.

During the second temperature profile period (4 August to 13 September 2008), mean maximum daily temperature at the $0 \mathrm{~m}$ down station was $1.9^{\circ} \mathrm{C}$ warmer than the reference stations in $90 \%$ removal streams (Figure 7). Maximum daily temperature reached a high of $20.2^{\circ} \mathrm{C}$ on 6 August in the $0 \mathrm{~m}$ down station in the $90 \%$ removal streams. Mean daily temperatures also had a similar pattern of increased warming downstream during the second temperature profile period in $90 \%$ removal streams. Mean daily temperature at the $0 \mathrm{~m}$ down station was $1.4^{\circ} \mathrm{C}$ warmer than the reference station for $90 \%$ removal streams during this period (Figure 8). Mean daily temperature peaked at $19.0^{\circ} \mathrm{C}$ on 13 September at the $0 \mathrm{~m}$ down station for $90 \%$ removal streams.

The $50 \%$ removal streams did not exhibit the large increases in stream warming seen in the $90 \%$ removal streams during the second temperature profile. During the second temperature profile period, mean maximum daily temperature for at the $0 \mathrm{~m}$ down station was $0.7^{\circ} \mathrm{C}$ warmer than the reference station (Figure 9). Maximum daily temperature reached a high of $18.6^{\circ} \mathrm{C}$ on 6 August in the $0 \mathrm{~m}$ down station in the $50 \%$ removal streams. Mean daily temperatures also had 
minimal increases during this profile period. Mean daily temperature at the $0 \mathrm{~m}$ down station was $0.4^{\circ} \mathrm{C}$ warmer than the reference station in the $50 \%$ removal streams during this period (Figure 10). Mean daily temperature peaked at $17.4^{\circ} \mathrm{C}$ on 6 August at the $0 \mathrm{~m}$ down station for $50 \%$ removal streams.

In some $90 \%$ removal streams there was temperature recovery as water flowed thru the buffer zones. Mitchell Lick had lower mean maximum daily temperatures at the $250 \mathrm{~m}$ down station $\left(19.1^{\circ} \mathrm{C}\right)$ than in $0 \mathrm{~m}$ up $\left(20.3^{\circ} \mathrm{C}\right)$ during the first temperature profile period (Figure 11). No other streams exhibited as strong of a pattern of temperature recovery through the buffer zones.

\section{TSS and turbidity}

Turbidity-TSS curves were separately modeled for 2007 and 2008 due to extreme differences in the levels of TSS observed (Figure 12). Comparisons of turbidity data from 2007 were variable between sections with no clear trend observed (Figure 13). Turbidity was opportunistically sampled after rain events on two occasions in 2008 (4 and 5 June) and turbidity measurements were higher in $90 \%$ removal than $50 \%$ removal streams. Turbidity measurements from 50\% removal streams were not different in the reference section than harvest sections $(\mathrm{p}=$ 0.289, Figure 14). Turbidity measures from the $90 \%$ removal streams were lower in reference areas at elevated turbidity levels $(\mathrm{p}=0.031)$. Total sediment loads per day were calculated using discharge and TSS concentrations for each study stream section on each day and ranged between 2 and $8197 \mathrm{~kg} / \mathrm{day}$ on the sample days (Figure 15). Sediment load per day was significantly higher in the down section of Schoolcraft Run on 4 June $2008(p=0.003)$. Sediment load per day was significantly higher in the reference section of Birch Fork on 4 June $2008(\mathrm{p}=0.022)$. 
Sediment load per day was significantly higher in the down section of Birch Fork on 5 June 2008 $(p=0.003)$. Sediment load per day was significantly higher in the down and up sections of South Panther Run on 5 June 2008 (Down, $\mathrm{p}=0.001$ : Up, $\mathrm{p}=0.001$ ).

\section{Discussion}

\section{LWD additions}

Removal of riparian vegetation during timber harvest operations and the subsequent addition of large woody debris to the stream channel resulted in opened canopies over the streambed, altered habitat structure, and increased water temperatures of the streams in our study. The addition of large woody debris had varying affects on stream channel morphology in the eight streams of this study. Stream sections with added LWD created new pools in all of the streams, but there was no net increase in pool area following habitat manipulation. Channel structure in these headwater streams was extremely dynamic, with new pools being created by LWD, and other pools being lost. In addition, many of the pools created by LWD were temporary, they formed one year post-treatment and disappeared the following year. Sweka and Hartman (2006) found that pools created one year were often lost by the next year. Hilderbrand et al. (1997) also noted that in high gradient streams receiving LWD, some of the pools created by their LWD additions quickly reverted back to riffle habitat. The lack of an effect on stream channel morphology may in part be due to stream gradient. Similar studies involving LWD additions to Appalachian streams, have found similar results. Sweka (2003) who studied streams in the same watershed found that the streams where LWD formed the most pools were the lowest gradient streams. Hilderbrand et al. (1997) found pool area significantly increased in a low gradient (1\%) stream, but did not change in a high gradient (3-6\%) stream. Both Hilderbrand et 
al. (1997) and Sweka and Hartman (2006) concluded that it may take several years for added LWD to modify stream channel habitat. In other studies, LWD addition to streams increased pool area (Binns 1994, Riley and Fausch 1995, Cederholm et al. 1997). However, in these studies the added LWD was imbedded into the stream bank or cabled to the riparian area. While engineered LWD structures are successful in the modification of stream channel morphology, these practices are extremely cost and labor intensive techniques that require the use of heavy equipment, sometimes within the stream channel. The methods used in our habitat manipulation were quite simple and practical as loggers could employ them while conducting normal harvesting operations. The inability of LWD additions to increase pool area may be due to the fact that the added LWD had not been in the streams long enough to become incorporated into the streambanks, and the majority of trees were felled across the stream channel and are hanging above the bankfull channel.

The amount of LWD found in the study streams after LWD addition greatly exceeded that reported in previous studies. We found that in our $250 \mathrm{~m}$ sections there was an average of 199 LWD pieces in 50\% removal streams and 320 LWD pieces in 90\% removal streams. Sweka (2003) found that LWD ranged from $32-77$ pieces per $300 \mathrm{~m}$ sections after experimental LWD addition. Flebbe and Doloff (1995) found a similar range of LWD pieces in old growth forests in the Appalachians. Although the LWD additions did not significantly increase the pool area in these streams, the LWD within the stream probably did serve other functions. The massive addition of organic debris to the LWD streams had many channel and ecological affects. Larger pieces of LWD are more likely to become anchored on stream banks or trees along the stream. The slash protected the channel from solar radiation and also acted as thermal insulation, mitigating the temperature impact of timber harvest. The hydraulic roughness provided by the 
leaves, twigs, and branches trapped fine sediment in the channels. In some streams, the channel became indistinct, and the water flowed through a matrix of mixed tree tops, logs, leaves and organic material. Although the methodology used to add LWD in this study failed to increase pool area significantly, the LWD within the streams likely functions similarly to such material in engineered LWD habitats. The full potential of the added LWD to modify the stream channel morphology may not be realized for many more years.

\section{Temperature effects}

Our study demonstrated that harvest of timber in a streamside management zone in the central Appalachian Mountains resulted in post-harvest increases in stream temperature. Streams in the $90 \%$ removal treatment had large increases in temperature $\left(3.1^{\circ} \mathrm{C}\right.$ mean max daily) while $50 \%$ removal treatment streams had small increases in temperature $\left(0.6^{\circ} \mathrm{C}\right)$. It appears from the small observed increases in temperature within $50 \%$ removal treatments that the current BMP guidelines that restrict harvest to $50 \%$ basal area within SMZ's is protective of coldwater streams. Increased removal of timber from SMZ's above the $50 \%$ threshold may result in increased stream temperatures creating marginal habitat for brook trout even if SMZ harvest is limited to less than $500 \mathrm{~m}$ of stream length. Post-harvest changes in stream temperatures and diurnal temperature fluctuations have been attributed mostly to increased levels of solar radiation reaching the stream channel (Brown and Krygier 1970). The extent of the increase in stream temperature following a harvest has been shown to be significantly correlated with the amount of timber retained in the riparian buffer (Brown and Krygier 1970, Caldwell et al. 1991, Macdonald et al. 2003). The $90 \%$ removal treatment had the greatest reduction in mean canopy closure from reference sites (58\%), and the greatest increases in mean daily maximum temperatures, 
temperature change within the harvest zone, and diurnal fluctuation following the timber harvest. In the $50 \%$ removal treatment, mean canopy closure decreased by an average of $14 \%$ in the removal sites as a result of the harvest. Increases in temperature were smaller than in the $90 \%$ removal treatment. Previous studies on unbuffered mountain streams showed average temperature increases of 3.2-5.0 ${ }^{\circ} \mathrm{C}$ (Brown and Krygier 1967, Burton and Likens 1973, Kochenderfer et al. 1997) as well as increases in diurnal fluctuation between $1.7-4.2^{\circ} \mathrm{C}$ (Brown and Krygier 1970) and 6.1-7.5 ${ }^{\circ} \mathrm{C}$ (Brown and Krygier 1967) above controls or preharvest conditions. Other researchers reported $1.4-4.4^{\circ} \mathrm{C}$ increases in mean weekly maximum temperatures and $2.3^{\circ} \mathrm{C}$ increases in diurnal fluctuation (Wilkerson et al. 2006).

Solar radiation is the most important factor influencing temperature regime in most small streams, though other factors can also contribute (Ward 1985). Other factors that could influence the magnitude of temperature response include groundwater inflow, hyporheic exchange and bed heat conduction, which tend to counteract solar heating during the daytime (Mellina et al. 2002, Story et al. 2003, Johnson 2004, Hannah et al. 2004). Groundwater inputs can strongly influence stream temperature (Sullivan et al. 1990, Caldwell et al. 1991), and groundwater inflow can mitigate effects of riparian tree removal by slowing temperature increases (Poole and Berman 2001) and by aiding in stream temperature recovery (Ice 2001). In small streams, post-harvest wood covering the channel can mitigate the effects of riparian vegetation removal on water temperatures by providing shade (Collier et al 1997). We suspect that the addition of large woody debris and tree tops along with groundwater inflow played a significant role in mitigating the effect of riparian tree removal in our study. Under current BMPs, large woody debris and tree tops must be extracted from the stream channel as LWD may cause bank erosion and channel blockage (West Virginia Division of Forestry 2005). Although not directly quantified, 
the addition of LWD and tree tops to our streams added much needed shade, especially in $90 \%$ removal sites. This added LWD may have tempered the effects of increased summer stream temperatures in the $90 \%$ removal streams, and should be considered as a management technique in coldwater streams that have large canopy openings.

Aquatic organisms are quite sensitive to changes in stream temperatures (Beitinger and Fitzpatrick 1979, Vannote and Sweeney 1980, Ward and Stanford 1992); increases in maximum stream temperature can be lethal, but increases of sublethal temperature result in changes in metabolism and growth rates (Medvick 1979, Thomas et al. 1986) as well as changes in food web dynamics and competitive interactions (Brett 1952, Reeves et al. 1987). Higher temperatures require more energy from biota to sustain increased metabolic rates and processes and can deplete the energy reserves of individual fish (Thomas et al. 1986). Increased temperature can also lead to greater virulence of bacterial diseases (Becker and Fugihara 1978) at a time when individuals are being subjected to thermal stress and have reduced resistance (Thomas et al. 1986). Upper thermal limits for organisms vary by species and life stage of the organism (Brett 1952, Coutant 1977), with the young generally being most sensitive to increases in the temperature of their environment. Elevation of water temperature and extreme diurnal fluctuation of temperature is a concern in brook trout streams because there is a particular temperature range in which body size, fecundity, and survival are optimized (Vannote and Sweeney 1980). Increased water temperature can result in physiological stress and potential death in brook trout (Grande and Anderson 1991). Documented lethal water temperature limits for brook trout range from $24.4^{\circ} \mathrm{C}$ (Brett 1956) to $26.2-27.2^{\circ} \mathrm{C}$ (Grande and Anderson 1991). The United States Environmental Protection Agency recommends that mean weekly maximum water temperatures do not exceed $24^{\circ} \mathrm{C}$ for even one week in streams with populations of brook 
trout (EPA 1986). In our study, mean daily temperature only exceeded $20^{\circ} \mathrm{C}$ on one stream (Mitchell Lick) for a two day period. However Mitchell Lick did have maximum daily temperature exceed $24^{\circ} \mathrm{C}$ for several days, which may have resulted in movement of fish or physiological stress. It is possible that the great daily fluctuations in stream temperatures in the removal sections may lead to changes in the structure of the aquatic community.

\section{Downstream temperature recovery}

Streams that are warmed in clearings sometimes cool as they flow back under intact forest canopy during the daytime (Greene 1950, Levno and Rothacher 1967, McGurk 1989, Keith et al. 1998). Such cooling would minimize the stream length impacted by warming and decrease the potential impacts of clear-cutting around headwater streams on downstream, fishbearing reaches. Within the $100 \mathrm{~m}$ buffer zone we observed decreases in stream temperature. In Mitchell Lick (90\% removal), stream temperatures difference between the start (0m up) and end (250 $\mathrm{m}$ down) of the buffer had mean daily temperatures that were $0.2-0.3^{\circ} \mathrm{C}$ cooler and maximum daily temperatures that were $0.6-2.8^{\circ} \mathrm{C}$ cooler. Previous studies of temperature recovery downstream of timber harvest reported large decreases in a relatively short downstream distance. Previous researchers have reported recovery after streams re-entered intact forest canopy of $1.2^{\circ} \mathrm{C}$ (McGurk 1989), and $1.5^{\circ} \mathrm{C}$ within $130 \mathrm{~m}$ (Caldwell et al. 1991), to as much as $5.5^{\circ} \mathrm{C}$ in $60 \mathrm{~m}$ (Keith et al. 1998). This common observation of relatively rapid reduction in temperature occurs because the intact forest canopy below the harvest zone shields the stream bed from direct solar radiation (Brown and Krygier 1970), while groundwater inflow and hyporheic exchange may further mitigate temperature increases produced in the harvest zone (Sullivan et al. 1990, Caldwell et al. 1991, Johnson and Jones 2000). Temperature recovery 
downstream of a harvest zone is important because a rapid decrease in temperature over a short distance can effectively limit the spatial impact of the harvest.

\section{Temporal temperature recovery}

Temperature recovery over time may also be important from a forest management perspective. Johnson and Jones (2000) found stream temperatures returned to pre-harvest levels in a clear-cut approximately 15 years after clear-cutting, which coincided with canopy closure in the riparian zone. Shade from the regenerating shrub layer may function as effectively as mature canopy at shading the stream from solar radiation (Johnson and Jones 2000). Low vegetation (shrubs and saplings) and instream woody debris and slash can partially shade the stream from solar radiation and mitigate temperature changes associated with harvesting (Feller 1981, Rishel et al. 1982, Caldwell et al. 1991, Jackson et al. 2001). Although some studies have observed a trend of decreasing maxima with each year post-harvest (Moring 1975, Swift and Messer 1971), others (Beschta and Taylor 1988) suggest that limited riparian vegetation re-growth during the first 5 years postharvest would not affect high maximum stream temperatures, but that during the next 15 years, the recovery of riparian vegetation would lead to a linear decrease in stream temperatures. It is suggested that future research studies measure shrub/tree height and stream temperatures in our streams each summer post harvest to describe temperature recovery following timber harvest.

\section{TSS and turbidity}

Turbidity levels were significantly higher in the $90 \%$ removal sections than in $90 \%$ reference sections when turbidity levels were elevated, potentially indicating greater soil 
disturbances in these sections. However, during normal flow events we found no difference between removal sections and reference sections in either $50 \%$ or $90 \%$ removal streams. Turbidity measurements from 50\% removal streams were not different in the reference section than harvest sections, indicating that the $50 \%$ removal streams still retained some capability to retain overland runoff of sediment during high flows. Total daily loads were considerably higher in some removal sections during the study, indicating increased erosion and sediment input due to disturbance. Thus, it appears that increasing harvest within the SMZ may result in increased turbidity during high flow events. Brown and Krygier (1971) also reported an increase in suspended solids after logging in Oregon streams. Martin et al. (2000) studied timber harvests and reference lands in New Hampshire and found increased amounts of sediment load on harvested lands when compared with uncut reference lands. However, these studies were setup differently than our study, as our study sections were located on the same stream and not paired watersheds. In addition, we did not have a large number of turbidity samples within this portion of the study, and the results may not be indicative of the system. 


\section{References}

Anderson, N. H., J. R. Sedell, L. M. Roberts, and F. J. Triska. 1978. The role of aquatic invertebrates in processing wood debris in coniferous forest streams. American Midland Naturalist 100:64-82.

Angermier, P. L., and J. R. Karr. 1984. Relationships between woody debris and fish habitat in a small warmwater stream. Transactions of the American Fisheries Society 113:716-726.

Arend, K. K. 1999. Stream reach surveys and measurements. Pages 47-56 in M. B. Bain and N. J. Stevenson, editors. Aquatic habitat assessment: common methods. American Fisheries Society, Bethesda, Maryland.

Bain, M. B. 1999. Substrate. Pages 95-104 in M. B. Bain and N. J. Stevenson, editors. Aquatic habitat assessment: common methods. American Fisheries Society, Bethesda, Maryland.

Becker, C. D., and M. P. Fujihara. 1978. The bacterial pathogen, Flexibacter columnaris, and its epizootiology among Columbia River fish: a review and synthesis. American Fisheries Society Monograph Number 2, Bethesda, Maryland.

Beitinger, T. L., and L. C. Fitzpatrick. 1979. Physiological and ecological correlates of preferred temperature in fish. American Zoologist 19:319-329.

Benke, A. C., T. C. Van Arsdall, Jr., and D. M. Gillespie. 1984. Invertebrate productivity in a subtropical blackwater river: the importance of habitat and life history. Ecological Monographs 54:25-36.

Berg, N., A. Carlson, and D. Azuma. 1998. Function and dynamics of woody debris in stream reaches in the central Sierra Nevada California. Canadian Journal of Fisheries and Aquatic Sciences 55:1807-1820.

Beschta, R. L. 1979. Debris removal and its effect on sedimentation in an Oregon coast range stream. Northwest Science 53:71-77.

Beschta, R. L., and W. S. Platts. 1986. Morphological features of small streams: structure and function. Water Resources Bulletin 3:369-379.

Beschta, R. L., and R. L. Taylor. 1988. Stream temperature increases and land use in a forested Oregon watershed. Water Resources Bulletin 24:19-25.

Beschta, R. L. 1996. Suspended sediment and bedload. Pages 123-143 in F. R. Hauer and G. A. Lambert, editors, Methods in stream ecology, Academic Press, San Diego.

Bilby, R. E., and G. E. Likens. 1980. Importance of organic debris dams in the structure and function of stream ecosystems. Ecology 61:1107-1113. 
Bilby, R. E., and J. W. Ward. 1989. Changes in characteristics and function of woody debris with increasing size of streams in western Washington. Transactions of the American Fisheries Society 18:368-378.

Binns, N. A. 1994. Long-term responses of trout and macrohabitats to habitat management in a Wyoming headwater stream. North American Journal of Fisheries Management 14:8798.

Bisson, P. A., J. L. Nielsen, R. A. Palmason, and L. E. Grove. 1982. A system of naming habitat types in small streams, with examples of habitat utilization by salmonids during low streamflow. Pages 62-73 in N. B. Armantrout, editor. Acquisition and utilization of aquatic habitat inventory information. American Fisheries Society, Western Division, Bethesda, Maryland.

Bisson, P. A., R. E. Bilby, M. D. Bryant, C. A. Dolloff, G. B. Grette, R. A. House, M. L. Murphy, K. V. Koski, and J. R. Sedell. 1987. Large woody debris in forested streams in the Pacific Northwest: Past, present, and future. Pages 143-190 in E. O. Salo, and T. W. Cundy, editors. Streamside management: forestry and fishery interactions. Contribution Number 57, Institute of Forest Resources, University of Washington, Seattle.

Bjornn, T. C., and D. W. Reiser. 1991. Habitat requirements of salmonids in streams. Pages 83138 in W. R. Meehan, editor. Influences of forest and rangeland management on salmonid fishes and their habitats. American Fisheries Society, Bethesda, Maryland.

Bonneau, J. L., and D. L. Scarnecchia. 1998. Seasonal and diel changes in habitat use by juvenile bull trout (Salvelinus confluentus) and cutthroat trout (Oncorhynchus clarki) in a mountain stream. Canadian Journal of Zoology 76:783-790.

Bowlby, J. N., and J.C. Roff. 1986. Trout biomass and habitat relationships in southern Ontario streams. Transactions of the American Fisheries Society 115:503-514.

Brett, J. R. 1952. Temperature tolerances in young Pacific salmon, Oncorhynchus. Journal of the Fisheries Research Board of Canada 9:268-323.

Brown, G. W., and J. T. Krygier. 1970. Effects of clear-cutting on stream temperature. Water Resources Research 6:1133-1139.

Brown, G. W. and J. T. Krygier. 1971. Clear-cut logging and sediment production in the Oregon coast range. Water Resources Research 7:1189-1198.

Bryant, M. D. 1983. The role and management of woody debris in west coast salmonid nursery streams. North American Journal of Fisheries Management 3:322-330.

Burton, T. M., and G. E. Likens. 1973. The effect of strip-cutting on stream temperature in the Hubbard Brook Experimental Forest, New Hampshire. BioScience 23:433-435. 
Cederholm, C. J., R. E. Bilby, P. A. Bisson, T. W. Bumstead, B. R. Fransen, W. J. Scarlett, and J. W. Ward. 1997. Response of juvenile coho salmon and steelhead to placement of large woody debris in a coastal Washington stream. North American Journal of Fisheries Management 17:947-963.

Clayton, J. L., E. S. Dannaway, R. Menendez, H. W. Rauch, J. J. Renton, S. M. Sherlock, and P. E. Zurbuch. 1998. Application of limestone to restore fish communities in acidified streams. North American Journal of Fisheries Management 18:347-360.

Clayton, J. L., and R. Menendez. 1998. Macroinvertebrate response to instream applications of fine grained limestone to mitigate acid deposition. USFWS progress report.

Collier, K. J., B. R. Baillie, E. J. Bowman, N. J. Halliday, J. M. Quinn, and B. J. Smith. 1997. Is wood in streams a dammed nuisance? Water and Atmosphere 5:17-21.

Coutant, C. C. 1977. Compilation of temperature preference data. Journal of Fisheries Research Board of Canada 34:739-745.

Davis, J. C. 1975. Minimal dissolved oxygen requirements of aquatic life with emphasis on Canadian species: a review. Journal of the Fisheries Research Board of Canada 32:22952332.

Dolloff, C. A., D. G. Hankin, and G. H. Reeves. 1993. Basinwide estimation of habitat and fish populations in streams. United States Forest Service, General Technical Report SE-83, Southeastern Forest Experiment Station, Asheville, North Carolina.

Dolloff, C. A. 1994. Large woody debris: the common denominator for integrated environmental management of forest streams. Pages 93-108 in J. Cairns Jr., T.V. Crawford, and H. Salwasser, editors. Implementing integrated environmental management. Center for Environmental Management and Hazardous Materials Studies, Virginia Polytechnic Institute and State University, Blacksburg, Virginia.

Dolloff, C. A., H. E. Jennings, and M. D. Owen. 1997. A comparison of basinwide and representative reach habitat survey techniques in three southern Appalachian watersheds. North American Journal of Fisheries Management 17:339-347.

Dudley, T. L., and N. H. Anderson. 1982. A survey of invertebrates associated with wood debris in aquatic habitats. Melanderia 39:1-21.

Eaglin, G. S., and W. A. Hubert. 1993. Effects of logging and roads on substrate and trout in streams of the Medicine Bow National Forest, Wyoming. North American Journal of Fisheries Management 13:844-846.

Elliot, J. M. 1993. The self-thinning rule applied to juvenile sea-trout, Salmo trutta. Journal of Animal Ecology 62:371-379.

Elliot, J. M. 2000. Pools as refugia for brown trout during two summer droughts: trout responses 
to thermal and oxygen stress. Journal of Fish Biology 56:938-948.

Environmental Protection Agency. 1986. Water quality criteria. EPA 440/5-86-001. Office of Water Regulations and Standards, Washington, D. C.

Fausch, K. D., and T. G. Northcote. 1992. Large woody debris and salmonid habitat in a small coastal British Columbia stream. Canadian Journal of Fisheries and Aquatic Sciences 49:682-693.

Feller, M. C. 1981. Effects of clear-cutting and slashburning on stream temperature in southwestern British Columbia. Water Resource Bulletin 17:863-867.

Flebbe, P. A. 1999. Trout use of woody debris and habitat in Wine Spring Creek, North Carolina. Forest Ecology and Management 114:367-376.

Flebbe, P. A., and C. A. Dolloff. 1995. Trout use of woody debris and habitat in Appalachian wilderness streams of North Carolina. North American Journal of Fisheries Management 15:579-590.

Fraley, J. J., and P. J. Graham. 1981. Physical habitat, geologic bedrock types and trout densities in tributaries of the Flathead River drainage, Montana. Pages 178-185 in N. B. Armantrout, editor. Acquisition and utilization of aquatic habitat inventory information. Western Division, American Fisheries Society, Bethesda, Maryland.

Freedman, B. 1989. Environmental Ecology: The impacts of pollution and other stresses on ecosystem structure and function. Academic Press, Toronto.

Grande, M., and S. Anderson. 1991. Critical thermal maxima for young salmonids. Journal of Freshwater Ecology 6:275-279.

Greene, G. E. 1950. Land use and trout streams. Journal of Soil and Water Conservation 5:125126.

Hakala, J. P., and K. J. Hartman. 2004. Drought effect on stream morphology and brook trout (Salvelinus fontinalis) populations in forested headwater streams. Hydrobiologia 515:203-213.

Hankin, D. G., and G. H. Reeves. 1988. Estimating total fish abundance and total habitat area in small streams based on visual estimation methods. Canadian Journal of Fisheries and Aquatic Sciences 45:834-844.

Heede, B. H. 1972. Influence of a forest on the hydraulic geometry of two mountain streams. Water Resources Bulletin 8:523-530.

Heifetz, J., M. L. Murphy, and K. V. Koski. 1986. Effects of logging on winter habitat of 
juvenile salmonids in Alaskan streams. North American Journal of Fisheries Management 6:52-58.

Herger, L. G., W. A. Hubert, and M. K. Young. 1996. Comparison of habitat composition and cutthroat trout abundance at two flows in small mountain streams. North American Journal of Fisheries Management 16:294-301.

Hicks, B. J., J. D. Hall, P. A. Bison, and J. R. Sedell. 1991. Responses of salmonids to habitat changes. Pages in W. R. Meehan, editor. Influences of forest and rangeland management on salmonid fishes and their habitats. American Fisheries Society, Bethesda, Maryland.

Hilderbrand, R. H., A. D. Lemly, C. A. Dolloff, and K. L. Harpster. 1997. Effects of large woody debris placement on stream channels and benthic macroinvertebrates. Canadian Journal of Fisheries and Aquatic Sciences 54:931-939.

Holman, G., and W. A. Evans. 1964. Stream clearance project-completion report Noyo River, Mendocino county, California Department of Fish and Game. Report 64-10.

Hunt, G. L. 1971. Response of a brook trout population to habitat development in Lawrence Creek. Wisconsin Department of Natural Resources, Technical Bulletin 48. Madison.

Huntingford, F. A., D. Aird, P. Joiner, K. E. Thorpe, V. A. Braithwaite, and J. D. Armstrong. 1999. How juvenile Atlantic salmon, Salmo salar L., respond to falling water levels: experiments in an artificial stream. Fisheries Management and Ecology 6:357-364.

Johnson S. L., and J. A. Jones. 2000. Stream temperature responses to forest harvest and debris flows in western Cascades, Oregon. Canadian Journal of Fisheries and Aquatic Sciences 57:30-39.

Johnson, S. L. 2004. Factors influencing stream temperatures in small streams: Substrate effects and a shading experiment. Canadian Journal of Fisheries and Aquatic Sciences 61:913-923.

Keith, R. M., T. C. Bjornn, W. R. Meehan, N. J. Hetrick, and M. A. Brusven. 1998. Response of juvenile salmonids to riparian and instream cover modifications in small streams flowing through second-growth forests of southeast Alaska. Transactions of the American Fisheries Society 127:889-907.

Keller, E. A., and F. J. Swanson. 1979. Effects of large organic material on channel form and fluvial processes. Earth Surface Processes 4:361-380.

Kochenderfer, J. N., P. J. Edwards, and F. Wood. 1997. Hydrologic impacts of logging an Appalachian watershed using West Virginia's best management practices. Northern Journal of Applied Forestry 14:207-218.

Kraft, M. E. 1972. Effects of controlled flow reduction on a trout stream. Journal of Fisheries 
Research Board of Canada 29:1405-1411.

Lee, P., C. Smyth, and S. Boutin. 2004. Quantitative review of riparian buffer width guidelines from Canada to the United States. Journal of Environmental Management 70:165-180.

Levno, A., and J. Rothacher. 1969. Increases in maximum stream temperatures after slash burning in a small experimental watershed. USDA Forest Service, Pacific Northwest Forest and Range Experiment Station, Research Note PNW-110. Portland, Oregon.

Lestelle, L. C., G. R. Blair, and S. A. Chitwood. 1993. Approaches to supplementing coho salmon in the Queets River, Washington. Pages 104-119 in L. Berg and P. W. Delaney, editors, Proceedings of the coho workshop, Canadian Department of Fisheries and Oceans, Vancouver.

Lewis, S. L. 1969. Physical factors influencing fish populations in pools of a trout stream. Transactions of the American Fisheries Society 98:14-19.

Macdonald, J. S., E. A. MacIsaac, and H. E. Herunter. 2003. The effect of variable-retention riparian buffer zones on water temperatures in small headwater streams in sub-boreal forest ecosystems of British Columbia. Canadian Journal of Forest Research. 33:13711382.

Martin, C. W., J. W. Hornbeck, G. E. Likens, and D. C. Buso. 2000. Impacts of intensive harvesting on hydrology and nutrients dynamics of northern hardwood forests. Canadian Journal of Fisheries and Aquatic Sciences 57(Suppl. 2):19-29.

McClurg, S. E., J. T. Petty, P. M. Mazik, and J. L. Clayton. 2007. Stream ecosystem response to limestone treatment in acid impacted watersheds of the Allegheny Plateau. Ecological Applications 17:1087-1104.

McGurk, B. J. 1989. Predicting stream temperature after riparian vegetation removal. Pages 157164 in Proceedings of the California riparian systems conference: Protection, management, and restoration for the 1990s. USDA Forest Service, General Techincal Report PSW-110, Davis, California.

Medvick, P. A. 1979. Growth rates of juvenile maomao, Abudefduf abdominalis, at constant and cyclic temperatures. Transactions of the American Fisheries Society 108:293-298.

Meehan, W. R, W. A. Farr, D. M. Bishop, and J. H. Patric. 1969. Some effects of clearcutting on salmon habitat of two Southeast Alaska streams. Pacific Northwest Forest and Range Experimental Station, Research Paper PM-82, Portland, Oregon.

Merrell, T. R. 1951. Stream improvement as conducted on the Clatskanie River and tributaries. Fisheries Commission of Oregon Research Briefs 3:41-47. 
Mills K. E., and N. J. Stevenson. 1999. Riparian Vegetation. Pages 125-133 in M. B. Bain and N. J. Stevenson, editors. Aquatic habitat assessment: common methods. American Fisheries Society, Bethesda, Maryland.

Montgomery, D. R., J. M. Buffington, R. Smith, K. M. Schmidt, and G. Pess. 1995. Pool spacing in forest channels. Water Resources Research 31:1097-1105.

Moring, J. R. 1975. The Alsea watershed study: effects of logging on aquatic resources of three headwater streams of the Alsea River, Oregon. Part II. Changes in environmental conditions. Oregon Department of Fish and Wildlife, Fisheries Research Report Number 9 , Corvallis.

Murphy, M. L., and W. R. Meehan. 1991. Stream ecosystems. Pages 17-46 in W. R. Meehan, editor. Influences of forest and rangeland management on salmonid fishes and their habitats. American Fisheries Society, Bethesda, Maryland.

Naiman, R. J., and J. R. Sedell. 1979. Benthic organic matter as a function of stream order in Oregon. Archiv fur Hydrobiologic 87:404-422.

Narver, D. W. 1971. The effect of logging debris on fish production. in Proceedings of a symposium, forest land uses and stream environment. School of Forestry and Department of Fisheries and Wildlife, Oregon State University, Corvallis.

Nicolson, J. R. 1975. Water quality and clear cutting in a boreal forest ecosystem. Pages 733738. in Proceedings of the Canadian hydrological symposium-75, National Research Council, Winnipeg.

Nip, A. M-K. 1991. The Tri-Creeks Experimental Watershed: Changes in hydrology and water quality following forest harvesting and their impact on salmonid fishes in the Tri-Creeks basin. Alberta Forest Service, Forest Research Branch Technical Report Number 4 Publication Number T/199.

Neumann, R. M., and T. L. Wildman. 2002. Relationships between trout habitat use and woody debris in two southern New England streams. Ecology of Freshwater Fish 11:240-250.

Nilslow, K. H., and W. H. Lowe. 2003. Influences of logging history and stream pH on brook trout abundance in first-order streams in New Hampshire. Transactions of the American Fisheries Society 132:166-171.

Overton, K. C., J. D. McIntyre, R. Armstrong, S. L. Whitwell, and K. A. Duncan. 1995. Users guide to fish habitat: descriptions that represent natural conditions in the Salmon River Basin, Idaho. USDA Forest Service, Intermountain Research Station, General Technical Report INT-GTR-322, Odgen, Utah.

Patric, J. H. 1980. Effects of wood products harvest on forest soil and water relations. Journal of Environmental Quality 9:73-80. 
Poole, G. C., and C. H. Berman. 2001. An ecological perspective on instream temperature: Natural heat dynamics and mechanisms of human-caused thermal degradation. Environmental Management 27:787-802.

Randolph, C. L., and R. G. White. 1984. Validity of the wetted perimeter method for recommending instream flows for salmonids in small streams. Research project technical completion report, Montana Water Resource Center, Montana State University, Bozeman.

Reice, S. R. 1974. Environmental patchiness and the breakdown of leaf litter in a woodland stream. Ecology 55:1271-1282.

Reeves, G. H., F. H. Everest, and J. D. Hall. 1987. Interactions between the redside shiner (Richardsonius balteatus) and the steelhead trout (Salmo gairdneri) in western Oregon: the influence of water temperature. Canadian Journal of Fisheries and Aquatic Science. 44:1603-1613.

Richmond, A. D., and K. D. Fausch, 1995. Characteristics and function of large woody debris in subalpine Rocky Mountain streams in northern Colorado. Canadian Journal of Fisheries and Aquatic Sciences 52:1789-1802.

Riley, S. C., and K. D. Fausch. 1995. Trout population response to habitat enhancement in six northern Colorado streams. Canadian Journal of Fisheries and Aquatic Sciences 52:3453.

Rosenfeld, J., M. Porter, and E. Parkinson. 2000. Habitat factors affecting the abundance and distribution of juvenile cutthroat trout (Oncorhynchus clarki) and coho salmon (Oncorhynchus kisutch). Canadian Journal of Fisheries and Aquatic Sciences 57:766-774.

Sanders, C. L. 2004. Sources and ecological consequences of deposited and suspended sediments in small tributaries of the upper Elk River Watershed, West Virginia. Master's Thesis. West Virginia University, Morgantown.

Sedell, J. R., P. A. Bisson, F. J. Swanson, and S. V. Gregory. 1988. What we know about large trees that fall into streams and rivers. Pages 47-81 in C. Maser, R. F. Tarrant, J. M. Trappe, and J. F. Franklin, technical editors. From the forest to the sea: a story of fallen trees. General Technical Report PNW-GTR-229. U.S. Forest Service, Pacific Northwest Research Station, Portland, Oregon.

Shearer, C. A. 1972. Fungi of the Chesapeake Bay and its tributaries III. The distribution of wood-inhabiting Ascomycetes and fungi imperfecti of the Patuxent River. American Journal of Botany 59:961-969.

Shields, F. D. 1998. Woody debris in river restoration: problems and opportunities. Water Resources Engineering 98:66-665. 
Silsbee, D. G., and G. L. Larson. 1983. A comparison of streams in logged and unlogged areas of Great Smokey National Park. Hydrobiologia 102:99-111.

Simonson, T. D., J. Lyons, and P. D. Kanehl. 1994. Quantifying fish habitat in streams: transect spacing, sample size, and a proposed framework. North American Journal of Fisheries Management 14:607-615.

Story, A., R. D. Moore, and J. S. Macdonald. 2003. Stream temperature in two shaded reaches below cutblocks and logging roads: Downstream cooling linked to subsurface hydrology. Canadian Journal of Forest Research 33:1383-1396.

Sullivan, K., J. Tooley, K. Doughty, J. E. Caldwell, and P. Knudsen. 1990. Evaluation of prediction models and characterization of stream temperatures regimes in Washington. Washington Department of Natural Resources, Timber/Fish/Wildlife Report Number TFW-WQ3-90-006, Olympia.

Sweka, J. A. 2003. Aquatic_terrestrial linkages in Appalachian streams: influence of riparian inputs on stream habitat, brook trout populations, and trophic dynamics. Doctoral dissertation. West Virginia University, Morgantown.

Sweka, J. A., and K. J. Hartman. 2006. Effects of large woody debris addition on stream habitat and brook trout populations in Appalachian streams. Hydrobiologia 559:363-378.

Swift, L. W., Jr., and J. B. Messer. 1971. Forest cuttings raise temperature of small streams in the southern Appalachians. Journal of Soil and Water Conservation 26:111-116.

Thomas, R.E., J. A. Gharrett, M. G. Carls, S. D. Rice, A. Moles, and S. Korn. 1986. Effects of fluctuating temperature on mortality, stress, and energy reserves of juvenile coho salmon. Transactions of the American Fisheries Society 115:52-59.

Triska, F. J., J. R. Sedell, K. Cromack, Jr., S. V. Gregory, and F. M. McCorison. 1984. Nitrogen budget for a small coniferous forest stream. Ecological Monographs 54:119-140.

Tschaplinski, P. J., and G. F. Hartman. 1983. Winter distribution of juvenile coho salmon (Oncorhynchus kisutch) before and after logging in Carnation Creek, British Columbia, and some implications for overwinter survival. Canadian Journal of Fisheries and Aquatic Sciences 40:452-461.

Vannote, R. L., and B. W. Sweeney. 1980. Geographical analysis of thermal equilibria: a conceptual model for evaluating the effect of natural and modified thermal regimes on aquatic insect communities. American Naturalist 115:667-695.

Ward, J. V. 1985. Thermal characteristics of running waters. Hydrobiologia 125:31-46.

Ward, J. V., and J. A. Stanford. 1992. Thermal responses in the evolutionary ecology of aquatic insects. Annual Review of Entomology 27:97-117. 
Warren, D. R., and C. E. Kraft. 2003. Brook trout (Salvelinus fontinalis) response to wood removal from high-gradient streams of the Adirondack Mountains (N.Y., U.S.A.). Canadian Journal of Fisheries and Aquatic Sciences 60:379-389.

Wesche, T. A. 1974. Relationship of discharge reductions to available trout habitat for recommending suitable streamflows. Water Resources Research Institute, University of Wyoming. Completion Report to Office of Water Research and Technology \& Wyoming Game and Fish Commission, Project B-023-WYO. Laramie.

West Virginia Division of Forestry, 2005. West Virginia silvicultural best management practices for controlling soil erosion and sedimentation from logging operations. WVDOF-TR-053 , Charleston.

West Virginia Division of Natural Resources. 2001. Middle Fork River limestone treatment of acid mine drainage. Final Report, Elkins.

Wilkerson, E., J. M. Hagen, D. Siegel, and A. A. Whitman. 2006. The effectiveness of different buffer widths for protecting headwater stream temperature in Maine. Forest Science $52: 221-231$.

Young, M. 1996. Summer movements and habitat use by Colorado River cutthroat trout (Oncorhynchus clarki pleuriticus) in small montane streams. Canadian Journal of Fisheries and Aquatic Sciences 53:1403-1408. 
Table 1. Summary descriptive stream statistics of the eight study streams in the Middle Fork River watershed, Randolph County, West Virginia (March 2005 - December 2008).

\begin{tabular}{lcccc}
\hline Stream & $\begin{array}{c}\text { Stream } \\
\text { Order }\end{array}$ & $\begin{array}{c}\text { Mean wetted } \\
\text { width }(\mathrm{m})\end{array}$ & $\begin{array}{c}\text { Mean Gradient } \\
(\%)\end{array}$ & $\begin{array}{c}\text { Mean Elevation } \\
(\mathrm{m})\end{array}$ \\
\hline Birch Fork & 2 & 3.22 & 2.92 & 847 \\
Kittle Creek & 2 & 2.42 & 2.99 & 780 \\
Mitchell Lick & 1 & 2.01 & 3.98 & 810 \\
Mulberry Fork & 1 & 1.95 & 4.95 & 701 \\
North Panther Run & 1 & 2.57 & 3.90 & 749 \\
Rocky Run & 2 & 3.28 & 3.77 & 890 \\
Schoolcraft Run & 2 & 2.97 & 2.89 & 737 \\
South Panther Run & 1 & 2.54 & 2.66 & 804 \\
\hline
\end{tabular}


Table 2. Pre-treatment (2005) habitat measurements of study streams.

\begin{tabular}{llcccc}
\hline Stream & Location & $\begin{array}{c}\text { Number } \\
\text { of pools }\end{array}$ & $\begin{array}{c}\text { Total Pool } \\
\text { length }(\mathrm{m})\end{array}$ & $\begin{array}{c}\text { Total Pool } \\
\text { area }\left(\mathrm{m}^{2}\right)\end{array}$ & $\begin{array}{c}\text { \% pool } \\
\text { area }\end{array}$ \\
\hline 50\% removal streams & & & & & \\
Birch Fork & Down & 8 & 50.8 & 169.6 & 22.643 \\
& Up & 5 & 64.8 & 267.3 & 28.599 \\
& Reference & 4 & 45.4 & 138.0 & 22.922 \\
Kittle Creek & Down & 7 & 35.5 & 91.7 & 16.447 \\
& Up & 5 & 16.8 & 46.2 & 9.093 \\
& Reference & 5 & 28.3 & 57.1 & 10.497 \\
Mulberry Fork & Down & 12 & 48.1 & 125.4 & 20.542 \\
& Up & 11 & 36.9 & 118.2 & 28.699 \\
& Reference & 12 & 28.8 & 96.2 & 19.080 \\
North Panther Run & Down & 1 & 4.0 & 10.1 & 1.318 \\
& Up & 6 & 32.9 & 120.6 & 21.868 \\
90\% removal streams & Reference & 5 & 13.9 & 22.9 & 4.756 \\
Mitchell Lick & & & & & \\
& Down & 6 & 24.6 & 46.5 & 15.497 \\
& Up & 7 & 32.7 & 67.4 & 23.153 \\
& Reference & 8 & 23.0 & 49.9 & 15.221 \\
Rocky Run & & & & & \\
& Down & 6 & 52.9 & 251.6 & 25.544 \\
& Up & 6 & 47.5 & 196.2 & 17.259 \\
& Reference & 8 & 68.4 & 245.2 & 23.928 \\
Schoolcraft Run & & & & & \\
& Down & 5 & 58.1 & 203.8 & 24.244 \\
& Up & 5 & 57.0 & 198.2 & 30.456 \\
& Reference & 6 & 49.0 & 151.7 & 24.085 \\
& & & & & \\
& Down & 8 & 50 & 136.4 & 26.612 \\
& Up & 10 & 58.7 & 147.0 & 34.867 \\
& reference & 5 & 30.7 & 72.9 & 15.567 \\
\hline
\end{tabular}


Table 3. Average (minimum, maximum) canopy closure for post harvest for each of the eight study streams.

\begin{tabular}{|c|c|c|c|}
\hline Stream & Section & $\begin{array}{l}\text { \% Canopy Closure } \\
\text { Mean }(\min , \max )\end{array}$ & $P$ \\
\hline \multicolumn{4}{|l|}{$50 \%$ removal streams } \\
\hline \multirow{3}{*}{ Birch Fork } & Removal & $86.9 \quad(67.8,96.2)$ & 0.0725 \\
\hline & Removal + LWD & $79.4 \quad(66.6,87.4) *$ & 0.0124 \\
\hline & Reference & $96.8 \quad(95.6,98.0)$ & - \\
\hline \multirow[t]{3}{*}{ Kittle Creek } & Removal & $74.9(58.8,96.4)^{*}$ & 0.0265 \\
\hline & Removal + LWD & $79.9(66.6,93.0)^{*}$ & 0.0119 \\
\hline & Reference & $97.3 \quad(94.8,99.2)$ & - \\
\hline \multirow[t]{3}{*}{ Mulberry Fork } & Removal & $93.5 \quad(84.0,97.8)$ & 0.0950 \\
\hline & Removal + LWD & $87.6,(82.2,96.0)^{*}$ & 0.0218 \\
\hline & Reference & $97.0 \quad(94.6,99.0)$ & - \\
\hline \multirow[t]{3}{*}{ North Panther Run } & Removal & $78.3(66.0,97.0)^{*}$ & 0.0167 \\
\hline & Removal + LWD & $93.3 \quad(86.2,97.2)$ & 0.1173 \\
\hline & Reference & $97.4 \quad(93.4,99.8)$ & - \\
\hline \multicolumn{4}{|l|}{$90 \%$ removal streams } \\
\hline \multirow[t]{3}{*}{ Mitchell Lick } & Removal & $18.1 \quad(7.6,35.0)^{*}$ & $<0.0001$ \\
\hline & Removal + LWD & $(0.4,43.6)^{*}$ & 0.0005 \\
\hline & Reference & $96.8 \quad(95.6,97.8)$ & - \\
\hline \multirow[t]{3}{*}{ Rocky Run } & Removal & $33.5(15.2,66.8)^{*}$ & 0.0019 \\
\hline & Removal + LWD & $(3.0,33.0)^{*}$ & $<0.0001$ \\
\hline & Reference & $94.7 \quad(92.4,97.4)$ & - \\
\hline \multirow[t]{3}{*}{ Schoolcraft Run } & Removal & $50.1(13.4,81.0)^{*}$ & 0.0109 \\
\hline & Removal + LWD & $45.0(11.6,74.4)^{*}$ & 0.0097 \\
\hline & Reference & $95.3 \quad(91.6,98.6)$ & - \\
\hline \multirow[t]{3}{*}{ South Panther Run } & Removal & $57.8(13.0,92.8)^{*}$ & 0.0189 \\
\hline & Removal + LWD & $67.6 \quad(22.0,94.8)$ & 0.0574 \\
\hline & Reference & $96.1 \quad(92.6,99.8)$ & - \\
\hline
\end{tabular}

Treatment means with an asterisk $\left(^{*}\right)$ are significantly different from the reference site. 
Table 4. Pool characteristics in the removal, removal plus large woody debris, and reference sections before $(2005)$ and after $(2007,2008)$ harvest.

\begin{tabular}{|c|c|c|c|c|c|c|c|c|c|}
\hline & \multicolumn{3}{|c|}{ Removal } & \multicolumn{3}{|c|}{ Removal + LWD } & \multicolumn{3}{|c|}{$\underline{\text { Reference }}$} \\
\hline & 2005 & 2007 & 2008 & 2005 & 2007 & 2008 & 2005 & 2007 & 2008 \\
\hline \multicolumn{10}{|l|}{$50 \%$ removal streams } \\
\hline Number of pools & 32 & 23 & 22 & 23 & 21 & 29 & 26 & 20 & 19 \\
\hline Mean pool length & 39.0 & 33.4 & 24.5 & 33.4 & 24.4 & 32.5 & 29.1 & 24.3 & 20.5 \\
\hline Mean pool area & 125.0 & 101.6 & 86.9 & 112.3 & 81.1 & 100.5 & 78.5 & 67.0 & 65.1 \\
\hline Total pool area & 500.0 & 406.4 & 347.6 & 449.1 & 324.4 & 402.1 & 314.2 & 268.0 & 260.5 \\
\hline$\%$ pool area of stream & 22.0 & 17.2 & 14.7 & 15.9 & 13.8 & 16.4 & 14.7 & 13.1 & 11.9 \\
\hline$\%$ Change in total pool area & & -19 & -14 & & -28 & 24 & & -15 & -3 \\
\hline \multicolumn{10}{|l|}{$90 \%$ removal streams } \\
\hline Number of pools & 28 & 33 & 27 & 25 & 31 & 29 & 27 & 24 & 24 \\
\hline Mean pool length & 50.6 & 56.8 & 36.3 & 44.8 & 41.9 & 28.0 & 42.8 & 37.4 & 35.3 \\
\hline Mean pool area & 167.5 & 173.1 & 109.8 & 144.3 & 128.5 & 88.5 & 129.9 & 103.4 & 113.2 \\
\hline Total pool area & 669.8 & 692.5 & 439.3 & 577.4 & 513.9 & 353.9 & 519.7 & 413.4 & 452.9 \\
\hline$\%$ pool area of stream & 26.4 & 23.4 & 19.3 & 22.2 & 18.8 & 16.4 & 21.2 & 15.3 & 18.5 \\
\hline$\%$ Change in total pool area & & 3 & -36 & & -11 & -31 & & -20 & 9 \\
\hline
\end{tabular}



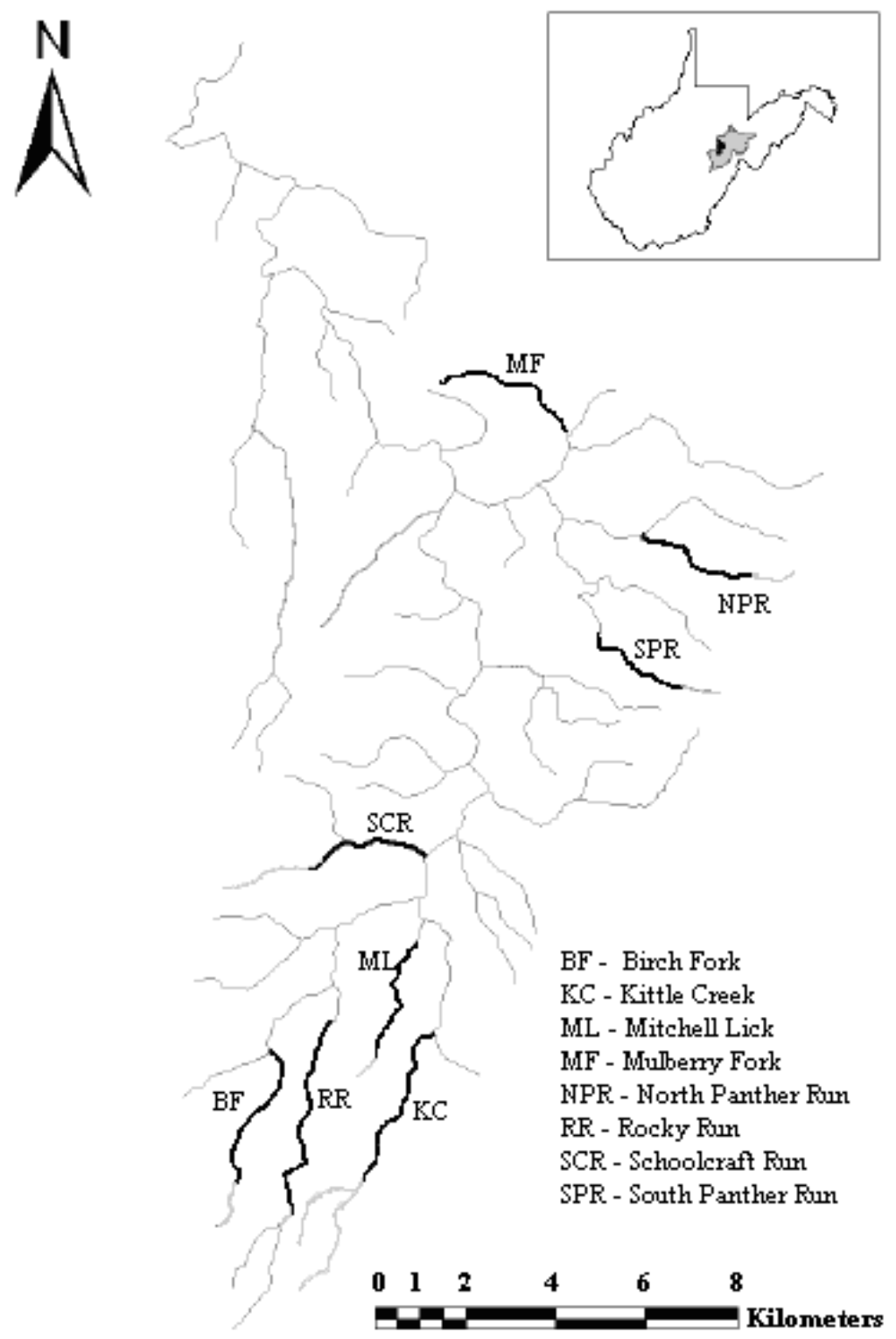

Figure 1. Middle Fork River Watershed, Randolph County, West Virginia. 


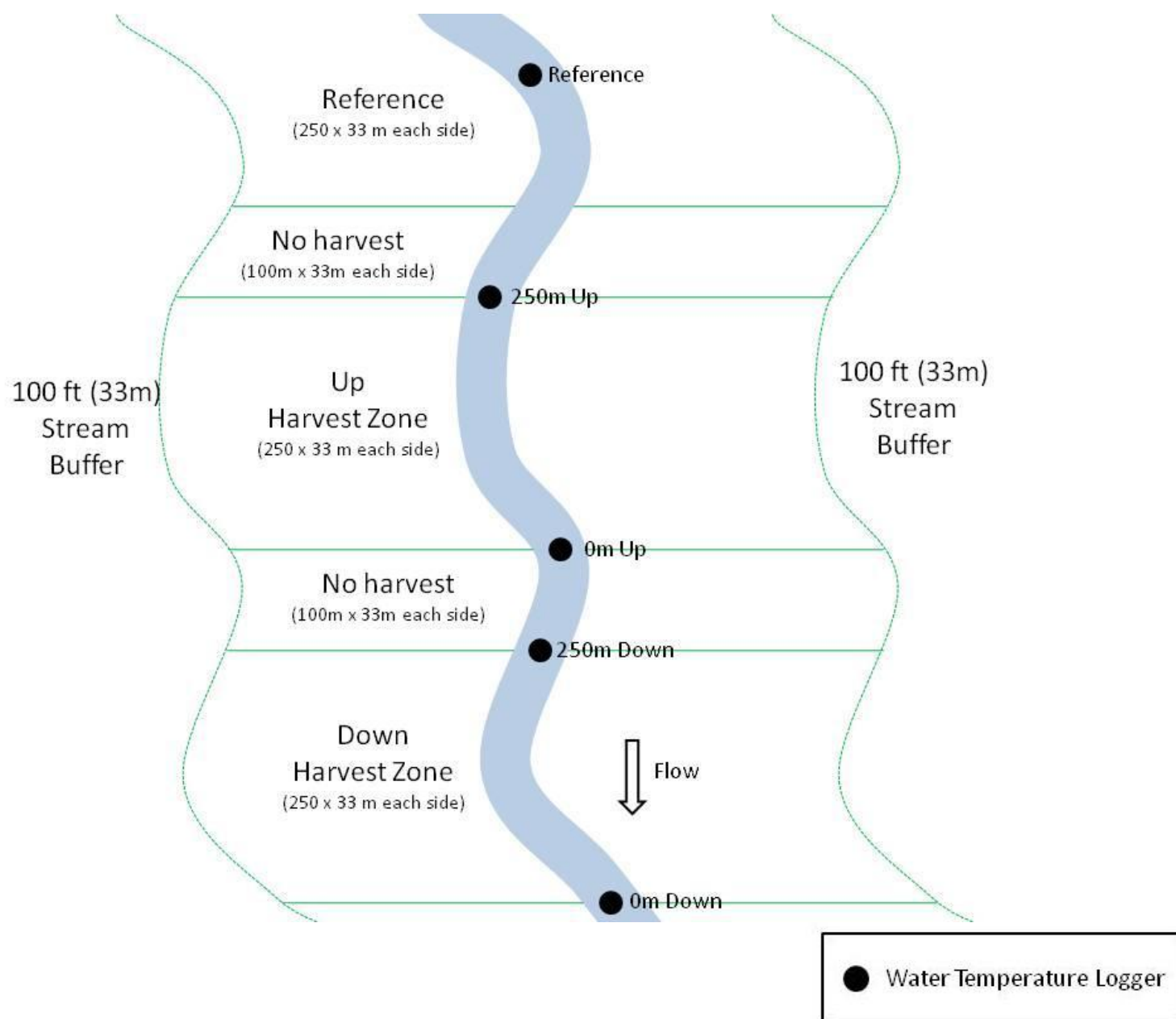

Figure 2. Schematic diagram of the stream sections in eight tributaries of the Middle Fork River, West Virginia. The removal and removal plus Large Woody Debris (LWD) sections were randomly placed in either the down or up treatment locations. * Note exaggerated lateral scale. 


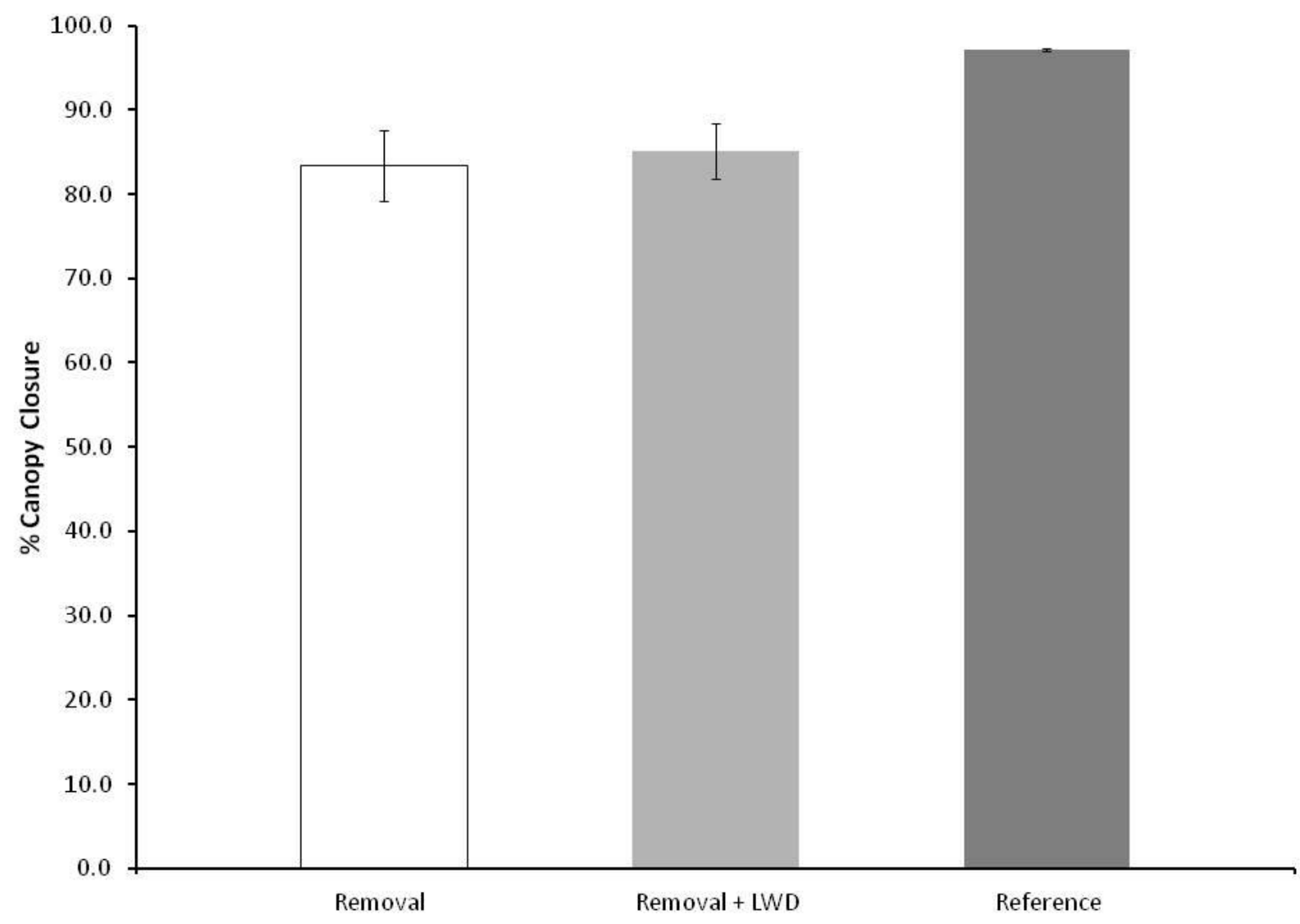

Figure 3. Percent canopy closure post harvest (2007) for 50\% removal streams. Error bars represent standard errors. 


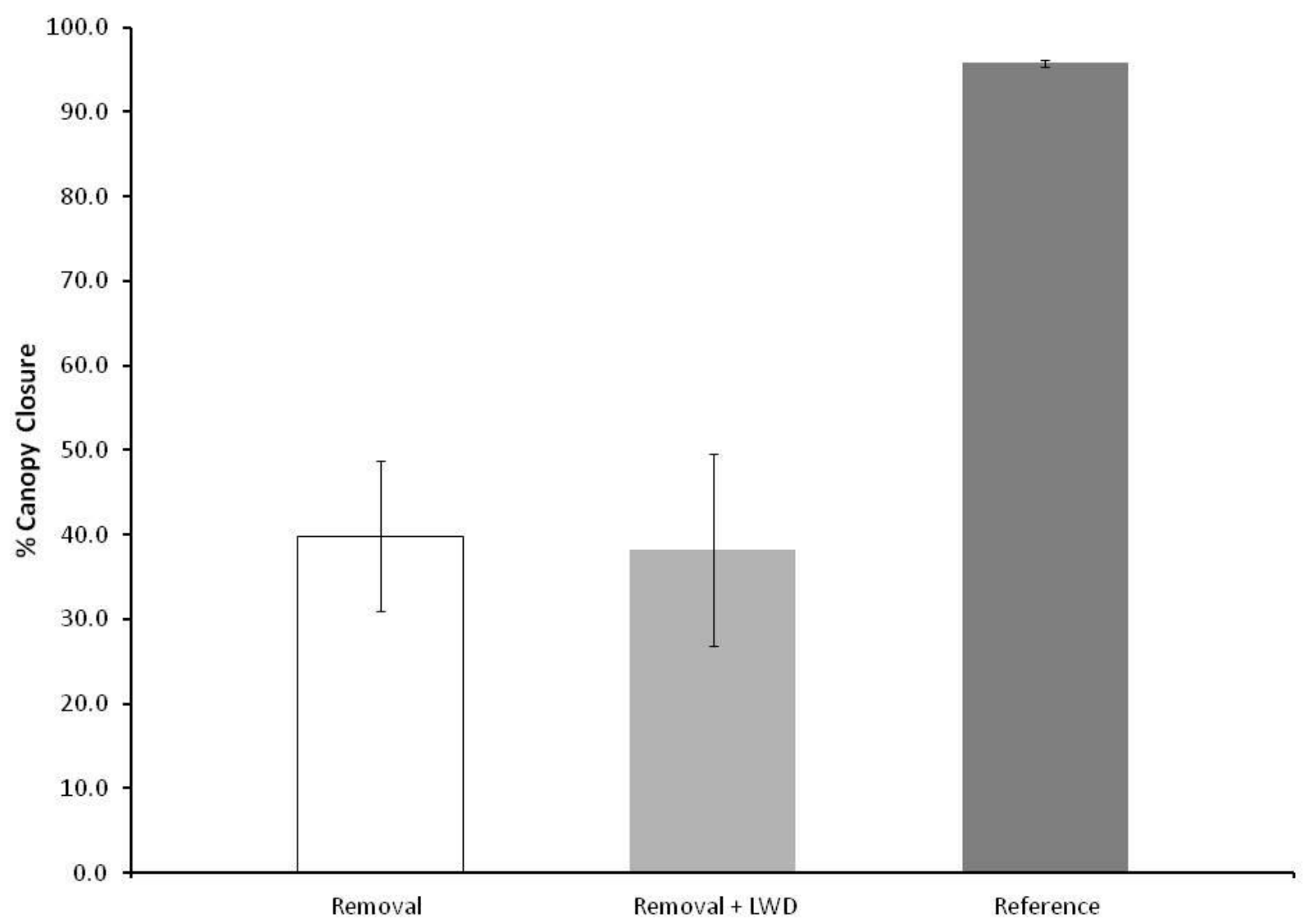

Figure 4. Percent canopy closure post harvest (2007) for $90 \%$ removal streams. Error bars represent standard errors. 

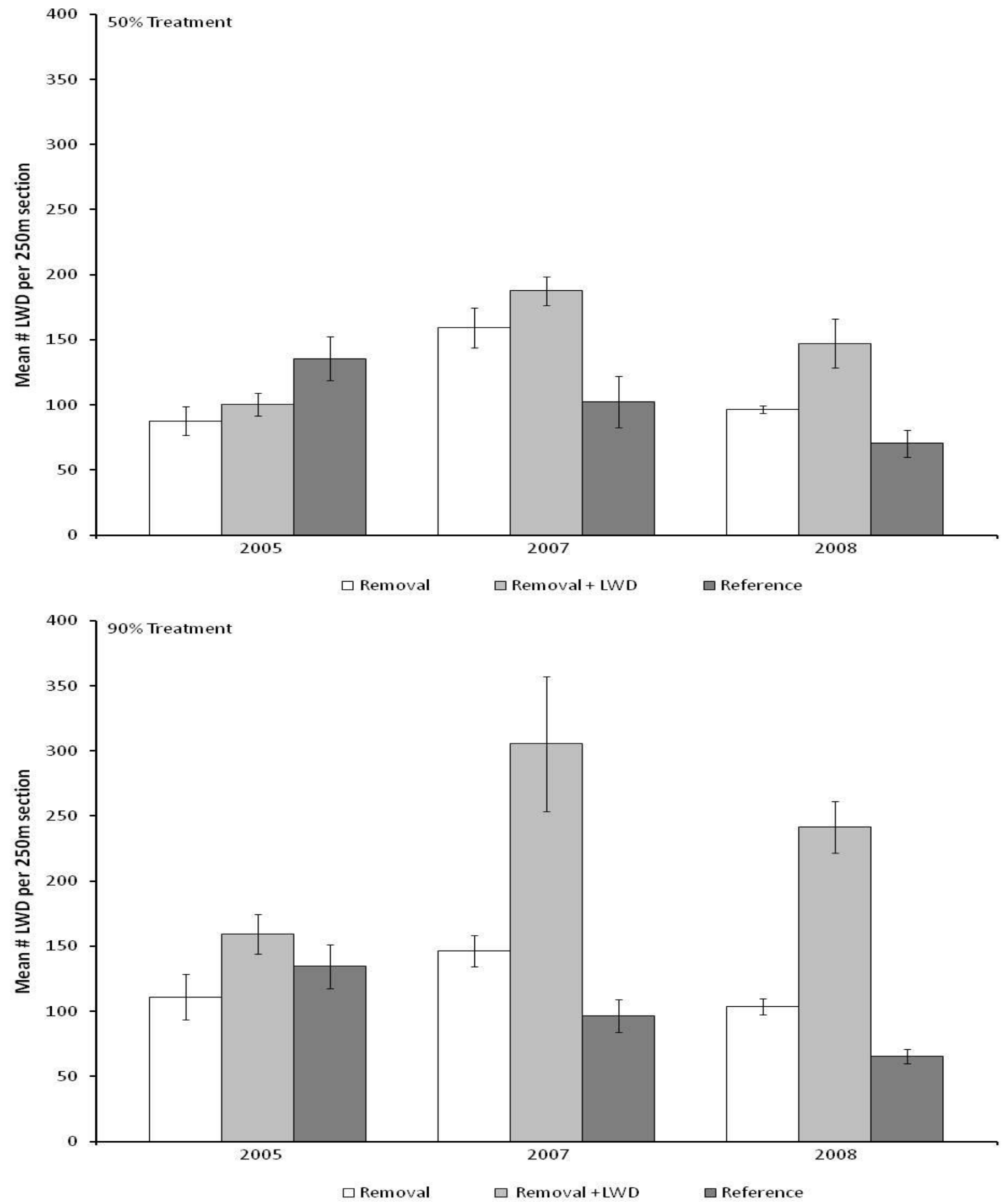

Figure 5. Mean number of pieces of LWD in 50\% and $90 \%$ removal treatments in study streams. 

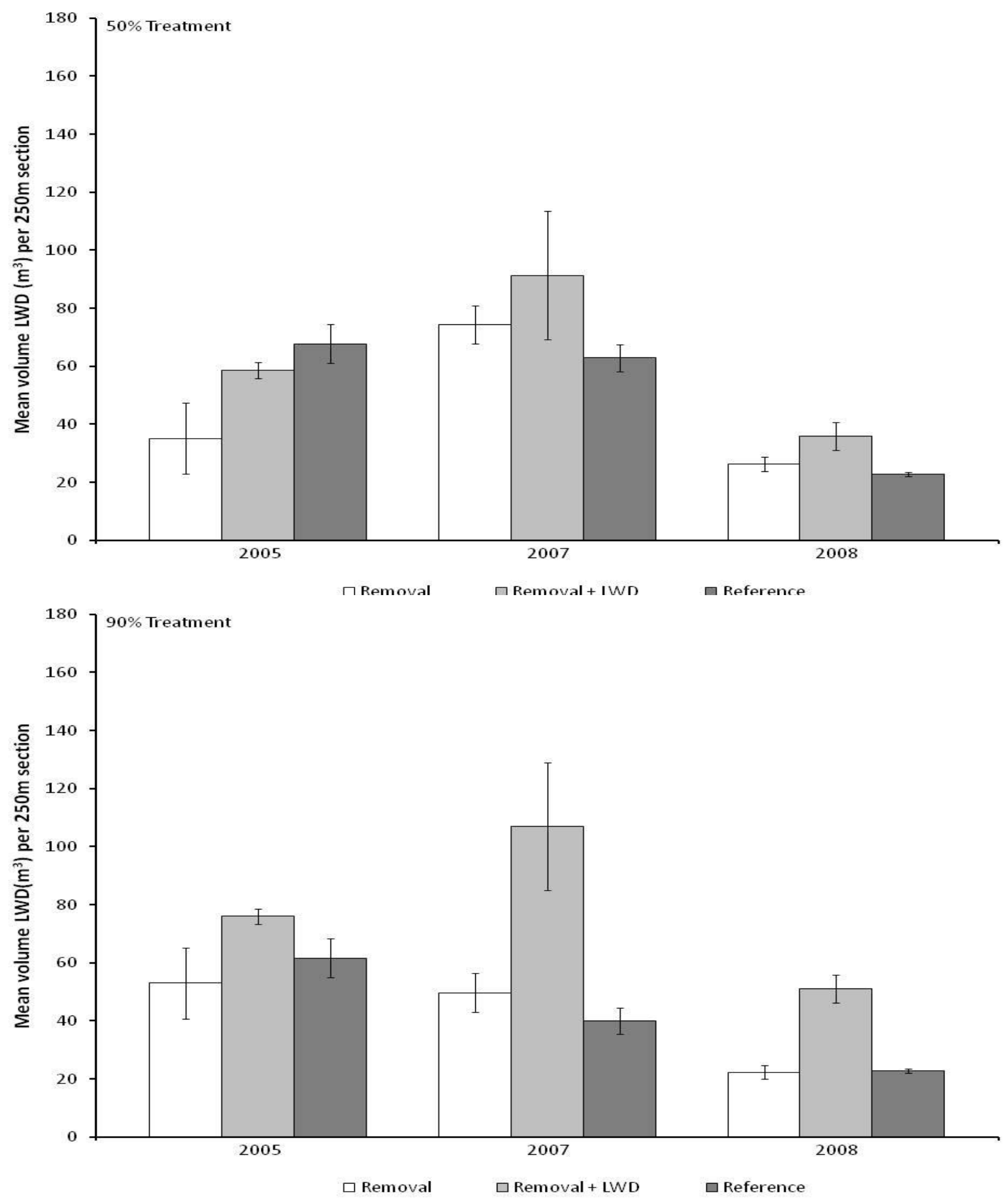

Figure 6. Mean volume of LWD in $50 \%$ and $90 \%$ removal treatments in study streams. 

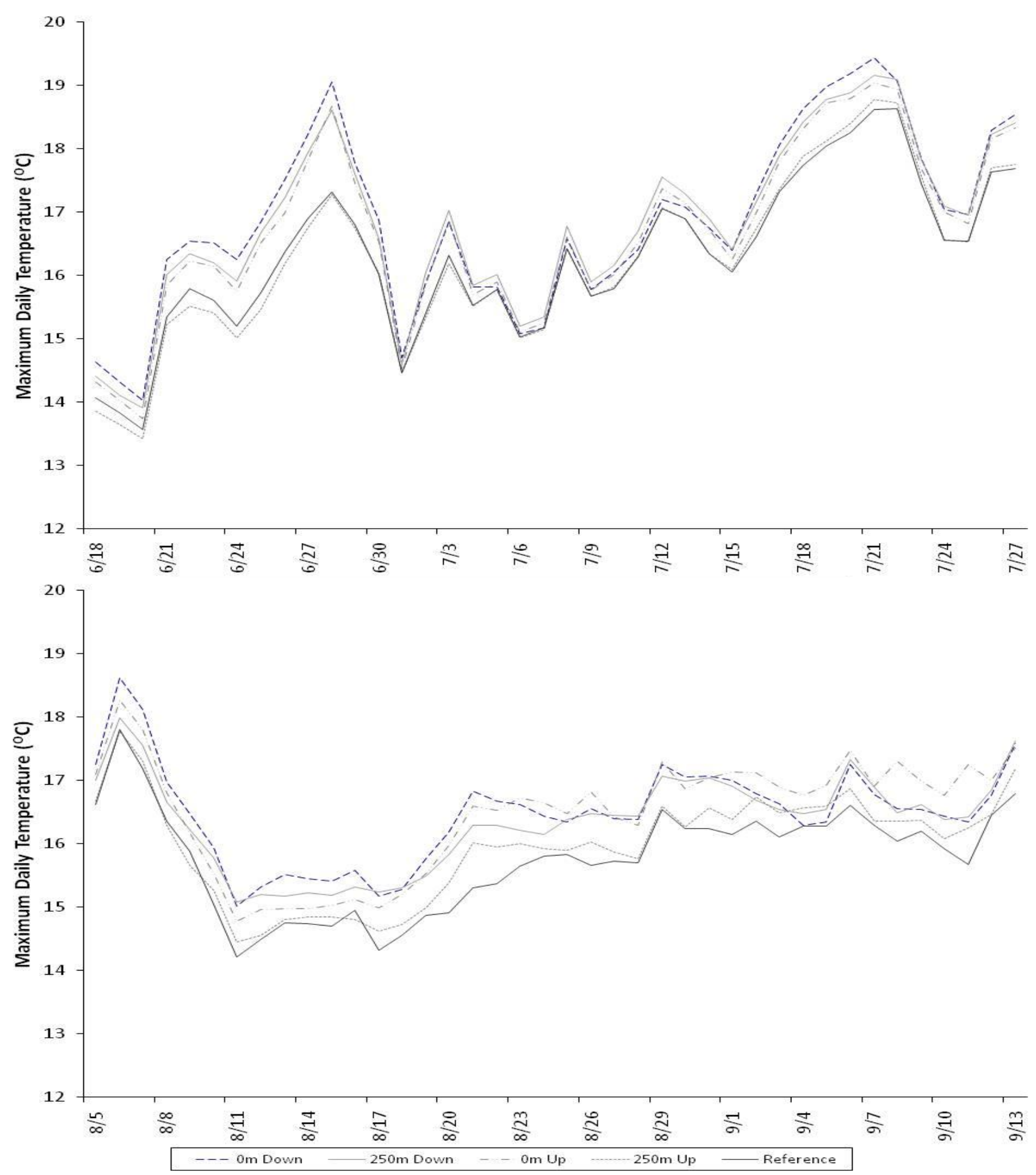

Figure 7. Maximum daily temperatures (Celsius) for the low, up, and reference sections of $50 \%$ removal streams in 2008 . 

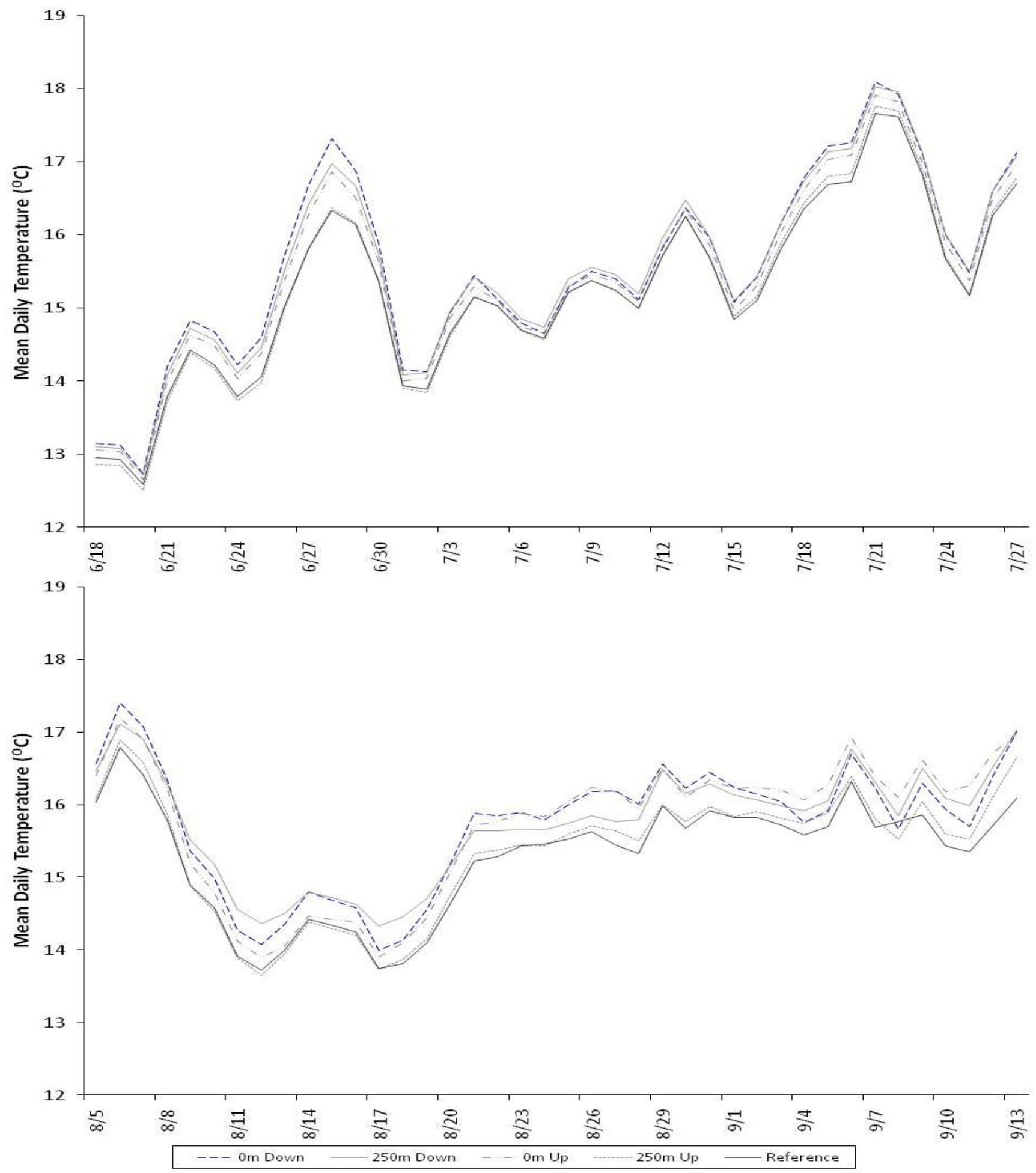

Figure 8. Mean daily temperatures (Celsius) for the low, up, and reference sections of 50\% removal streams in 2008 . 


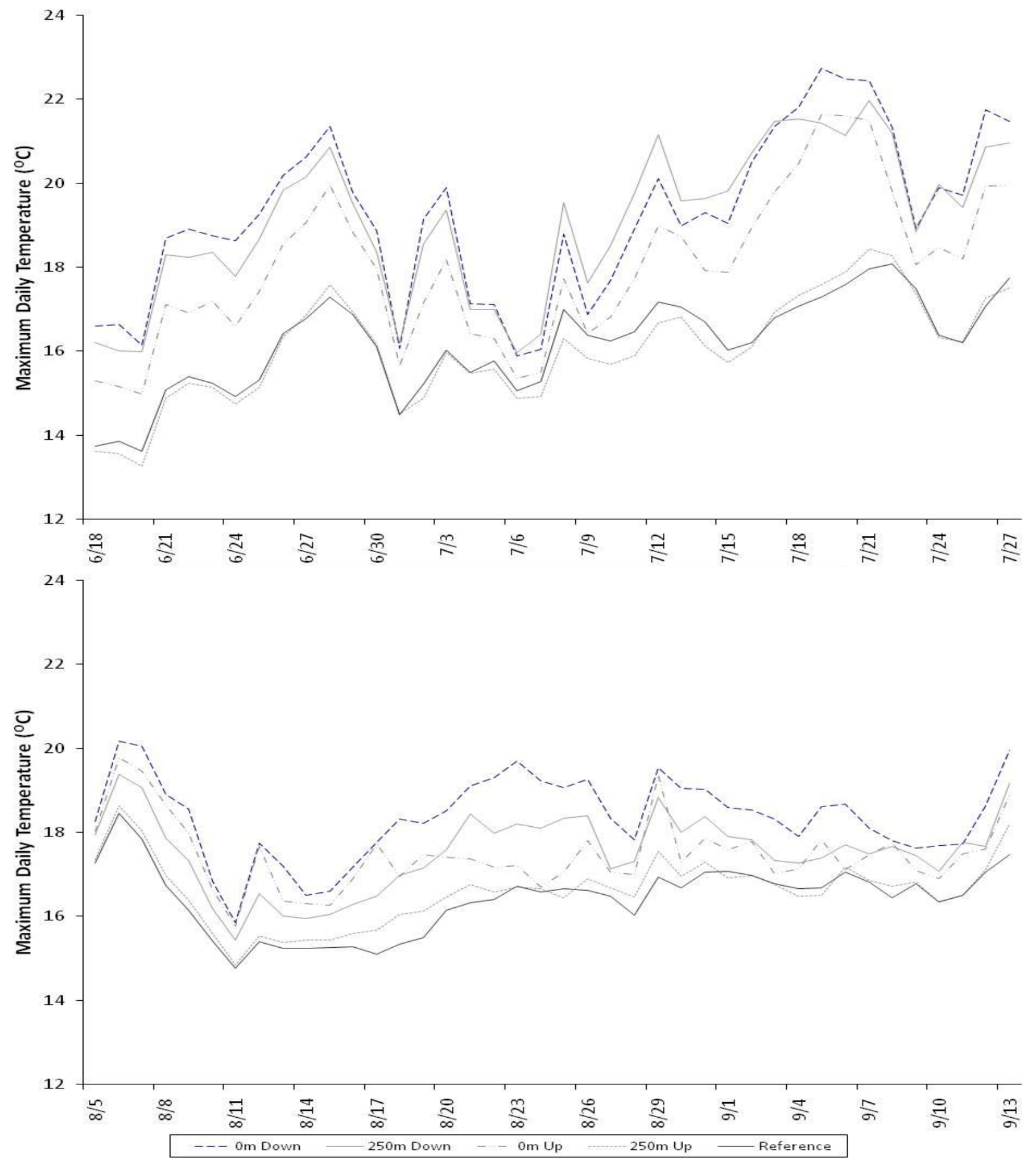

Figure 9. Maximum daily temperatures (Celsius) for the low, up and reference sections of $90 \%$ removal streams in 2008. 

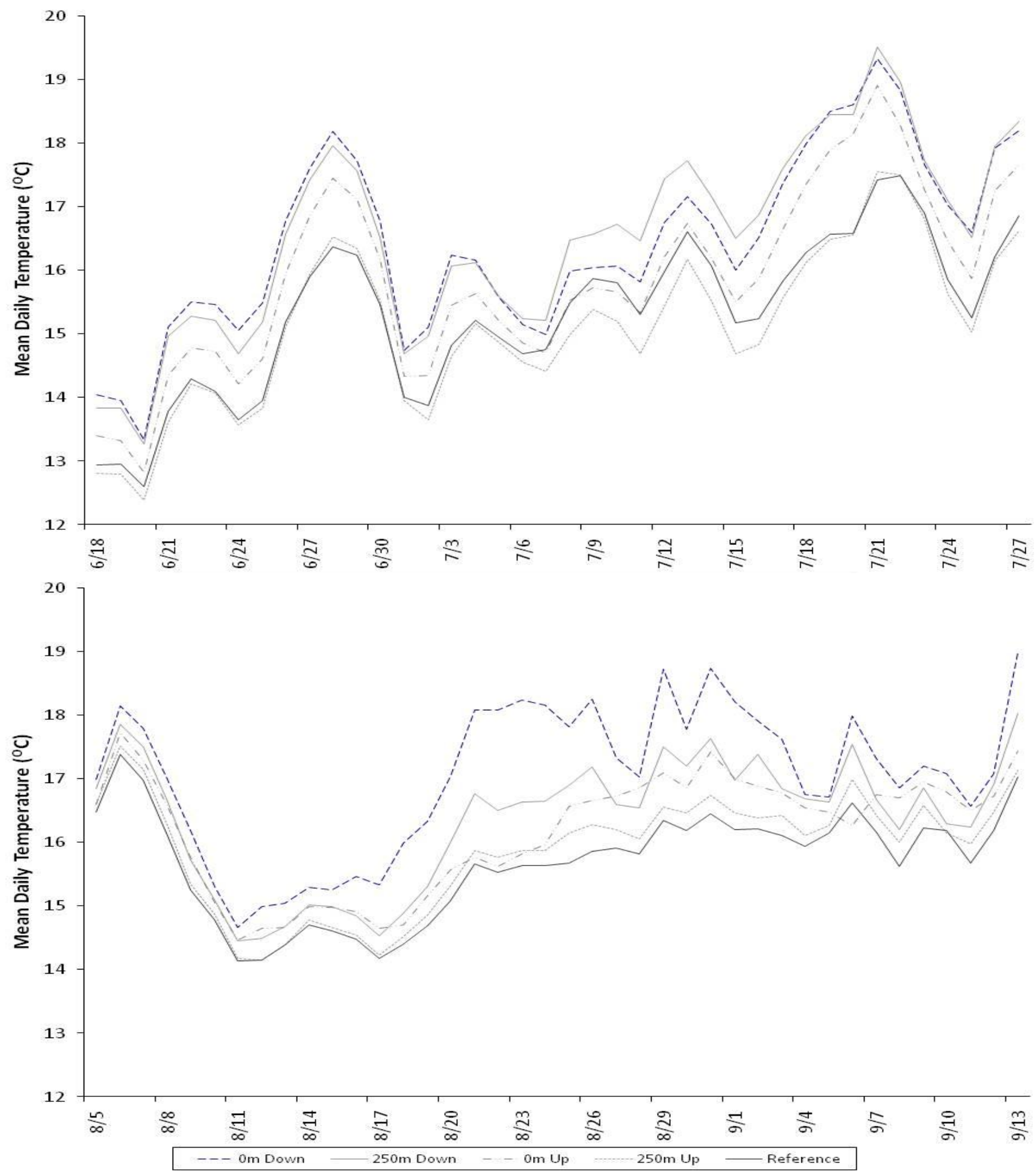

Figure 10. Mean daily temperatures (Celsius) for the low, up and reference sections of $90 \%$ removal streams in 2008 . 




Figure 11. Maximum and mean daily temperatures (Celsius) for the low (removal plus Large Woody Debris) and up (removal), and reference sections of Mitchell Lick in 2008. 


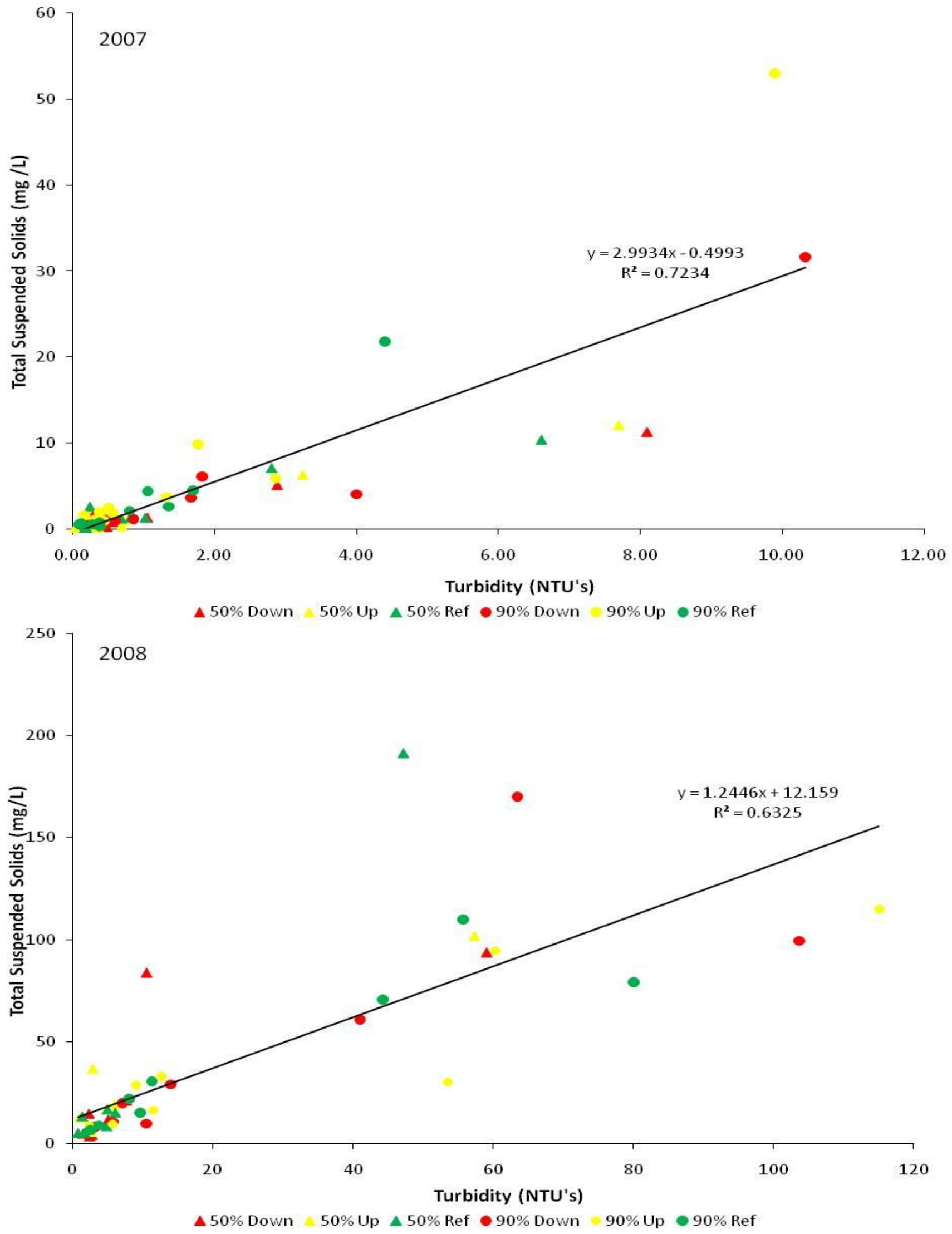

Figure 12. Turbidity-TSS curves from the $50 \%$ and $90 \%$ removal treatment sections in 2007 and 2008. Note differences of scale between 2007 and 2008. 

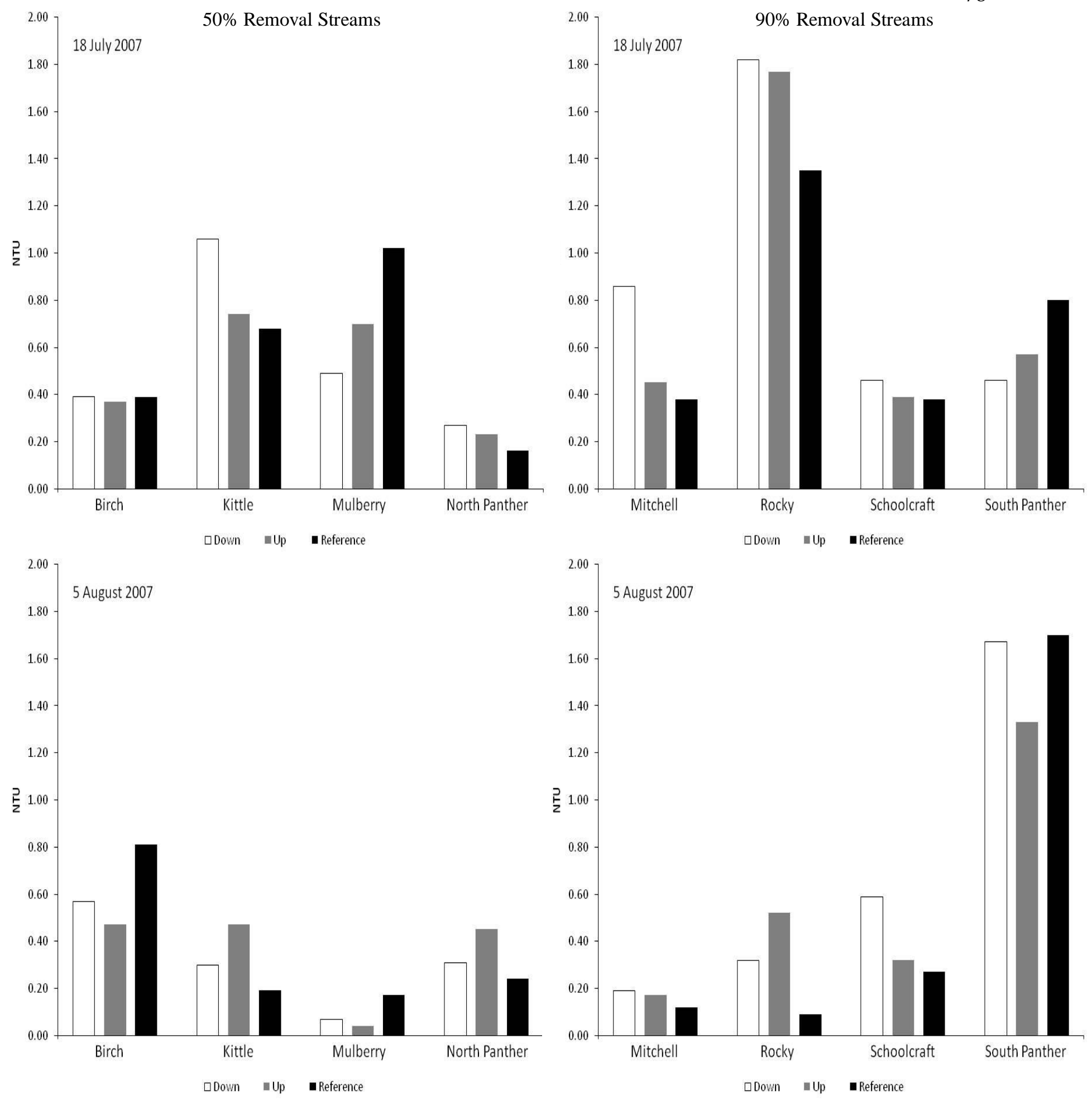

Figure 13. Turbidity (NTU) measured in stream sections during 2007 opportunistic sampling. 

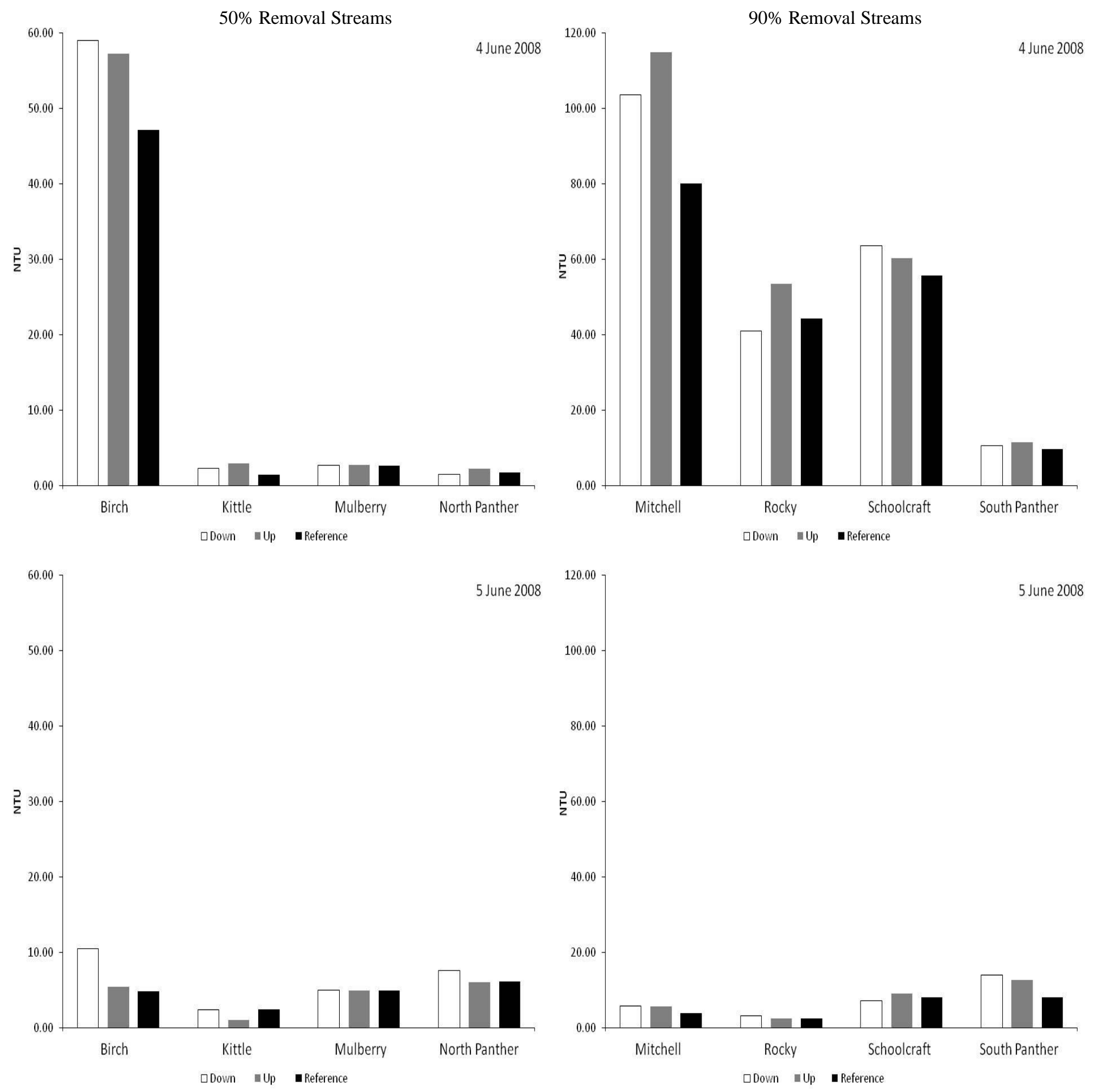

Figure 14. Turbidity (NTU) measured in stream sections during 2008 opportunistic sampling. Note differences of scale between $50 \%$ and $90 \%$ streams. 
$50 \%$ Removal Streams
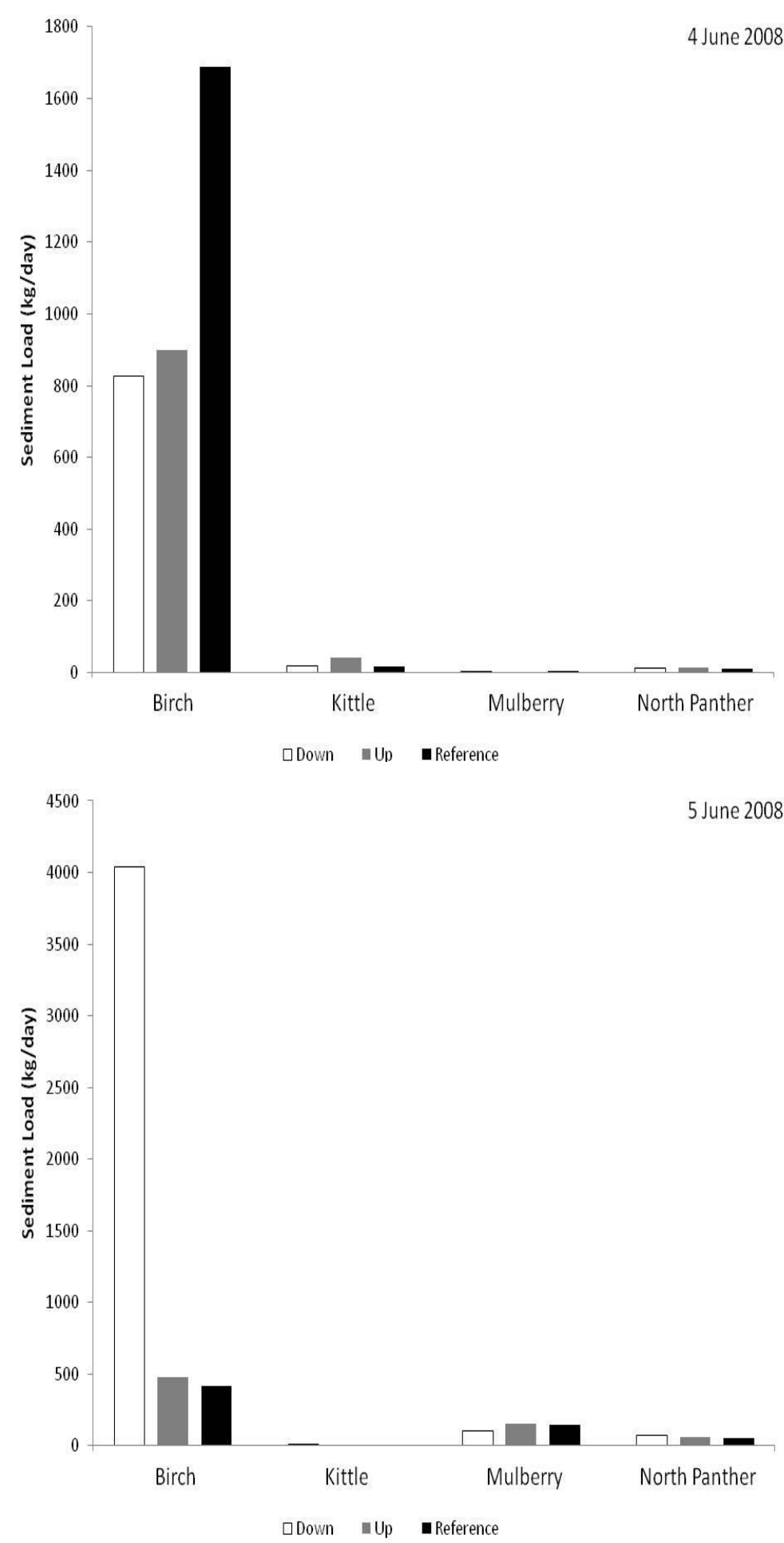

90\% Removal Streams
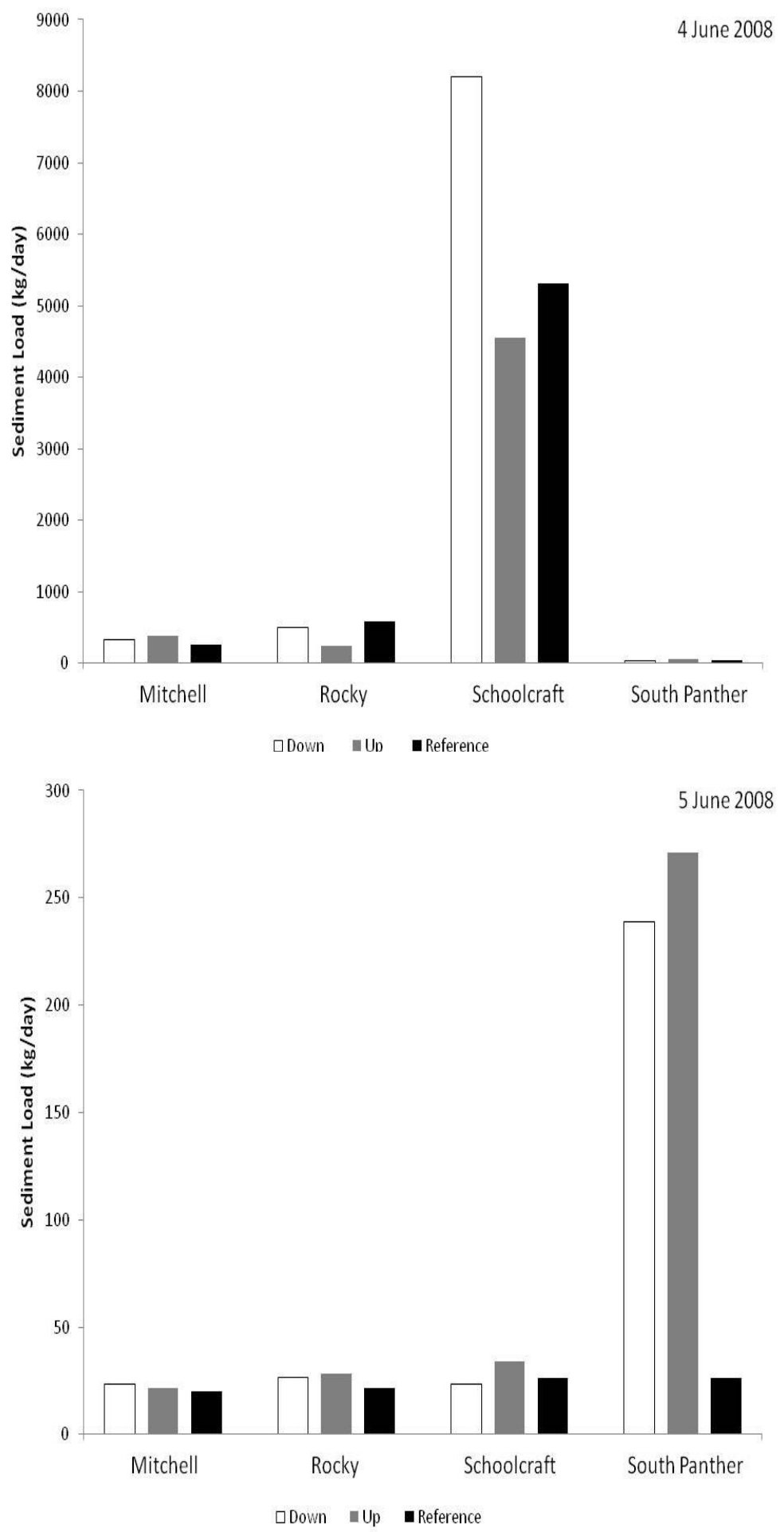

Figure 15. Total sediment load (kg/ day) measured in stream sections during 2008 opportunistic sampling. Note differences of scale. 
Chapter 3. The Role of Riparian Removal and Large Woody Debris Additions in Structuring Brook Trout Populations in Central Appalachian Streams

\begin{abstract}
Riparian zones play an important role in the physical, chemical, and biological
\end{abstract} dimensions of headwater stream ecosystems. Conventional stream theory predicts that terrestrial subsidies dominate the energy base of food webs in headwater streams where primary production is limited by shading. Large woody debris (LWD) is also an important habitat component in small headwater streams and many studies have shown positive correlations between the abundance of LWD and stream fish density. Riparian logging alters the processes and features that shape stream ecosystems and can determine population density, condition, size, and community structure of salmonids. To understand how logging of streamside management zones (SMZ) affects populations of Appalachian brook trout (Salvelinus fontinalis), we examined trout density, length, and body condition (relative weight), seasonally in eight headwater streams over a 3-year period (1 year pre-logging [2005] and 2 years post-logging [2007-2008]). This study is one of the first efforts to conduct a multiyear, replicated, before-after experiment to assess the effects of riparian tree removal and removal plus LWD addition on brook trout. Three $250 \mathrm{~m}$ study sections were established on eight Appalachian headwater streams. Four of the streams were assigned treatment of a 50\% basal area removal of SMZ timber and four were assigned a $90 \%$ basal area removal of SMZ timber. The down and up sections of each stream were then randomly assigned to be either basal area removal (removal) treatment or basal area removal plus instream LWD addition (removal + LWD) treatment, with reference sections located upstream of the treatment sections. Seasonal population estimates of brook trout were conducted in 2005 (pre-treatment) 2007 and 2008 (post-treatment). There was no significant removal x time effect 
for YOY or age 1+ brook trout density in either the 50 or $90 \%$ streams. YOY brook trout density was significantly higher in removal + LWD sections for both 50\% and 90\% streams during June 2007. Age 1+ brook trout density in reference sections was not significantly different than removal and removal + LWD sections for 50\% and $90 \%$ streams during any post harvest sample. Mean total length of YOY brook trout did vary across some streams and sections but was not significant among treatments. Mean total length of age $1+$ brook trout was higher in removal and removal + LWD sections of 50\% streams during November 2007 (p = 0.024). The condition $\left(\mathrm{W}_{\mathrm{r}}\right)$ of age $1+$ brook trout $(>120 \mathrm{~mm})$ did not differ between treatment (removal and removal+ LWD) and reference sections in 50\% or 90\% streams. Overall percent retention of resident fish differed significantly between sections $(\mathrm{p}=0.030)$. Percent retention was greatest in reference sections of 50\% streams and lowest in the removal + LWD sections of 90\% streams. Percent immigration was high in all sections (60-71\%) suggesting high rates of movement. While LWD additions within the stream did not increase brook trout densities, they may have supplied other benefits to the stream by increasing retention of organic matter, potentially increasing macroinvertebrate production, and creating overhead cover and refugia. These potential benefits associated with LWD addition could increase brook trout abundance through the retention of resident fish and attraction of immigrant fish. However, it may take several years before the full effects of riparian tree removal and removal plus LWD additions is seen on stream habitat and brook trout populations. 


\section{Introduction}

Riparian zones are among the most diverse and functionally important ecotones on earth (Naiman et al. 1998). Riparian-zone vegetation plays an important role in the biotic associations of streams (Cummins et al. 1984). Riparian vegetation influences the physical channel (e.g., large woody debris, bank stabilization, shading, etc.) and allochthonous and autochthonous sources of organic inputs to the streams (Cummins et al. 1984, Hetrick et al. 1998). Riparian vegetation modifies light and temperature regimes, provides food for aquatic and terrestrial consumers and is the source of woody debris to streams (Pollock 1998).

The removal of riparian trees along streams or lakes can affect aquatic ecosystem structure and function (Platts and Megahan 1975, Vouri and Joensuu 1996). Removal of the riparian overstory vegetation changes the trophic status of a stream from primarily allochthonous energy sources to primarily autochthonous energy sources (Cummins 1974, Minshall 1978). With removal of the canopy, light and water temperature usually increase and the input of nutrients may change (Cummins 1974). A large body of previous research from New England and the Pacific Northwest has provided general agreement on the physical effects resulting from logging practices (Garman and Moring 1991, Waters 1995, Hartman et al.1996), all of which are generally applicable to Appalachian streams. Many investigators have studied the effects of clear-cut logging on stream morphology (Toews and Moore 1982a), large and small organic debris (Toews and Moore 1982a, 1982b), macroinvertebrate communities (Newbold et al. 1980, Murphy and Hall 1981, Hawkins et al. 1983, Duncan and Brusven 1990), and fish communities (Sheridan and McNeil 1968, Burns 1972, Murphy and Hall 1981, Murphy et al. 1981, Hawkins et al. 1983, Heifetz et al. 1986, Johnson et al. 1986). Riparian forest harvest can increase sediment delivery to streams (Chamberlin et al. 1991), covering stream substrates (Davies and 
Nelson 1994) and negatively affecting some stream organisms (Osmundson et al. 2002). In small, headwater streams, one of the major microclimatic changes resulting from riparian logging is an increase in solar energy reaching the stream surface (Brosofske et al. 1997). Increased solar energy can affect a host of factors such as water temperature (Beschta 1997), primary production (Hill et al. 1995) and insect abundance (Fuller et al. 1986). Logging may strongly influence the distribution and abundance of stream macroinvertebrates, critical links in headwater stream food webs (Stone and Wallace 1998, Williams et al. 2002). Increased sedimentation and embeddedness has been shown to decrease overall invertebrate abundance and diversity in some studies (Murphy et al. 1981, Harding et al., 1998), while in others, increased light penetration and nutrient availability have yielded higher standing stocks of invertebrate biomass in logged catchments (Gurtz and Wallace 1984, Anderson, 1992, Kiffney et al. 2003). Riparian logging can alter the biological, chemical, and physical processes and features that shape stream ecosystems and determine population density and community structure of salmonids (Gregory et al. 1987, Reeves et al. 1993). Several researchers reported increases in the abundance of juvenile salmonids after clear-cut logging watersheds to the streambank (Johnson et al. 1986, Murphy et al. 1986, Thedinga et al. 1989); they attributed increases in abundance of fish to increases in abundance of prey that resulted from increased primary production. Dolloff (1986) and Elliott (1986) evaluated the effects of stream cleaning after clear-cut logging on fish communities in small streams in southeast Alaska, and found that fewer juvenile salmonids were present in sections of streams that had woody debris removed than in streams with woody debris intact. Murphy and Hall (1981) found increased biomass, density, and species richness of aquatic vertebrate and invertebrate predators in streams flowing through clear-cuts still exposed to sunlight when compared with similar old-growth stands; increases 
were greatest in small first-order streams. They also found that initial increases in production did not last as clear-cuts became reforested with second-growth red alder (Alnus rubra). In older clear-cut stream sections that had become shaded by deciduous forest canopy, biomass of salmonids and macroinvertebrate taxa was lower than in old-growth streams (Murphy and Hall 1981).

The loss of large organic debris that enters streams is an additional effect of removing trees from riparian zones. The input of coarse (large branches, trees, etc.) and fine (small branches, leaves, needles, bark) woody debris is a natural process in forest ecosystems and plays an important role in providing fish habitat. The extraction of timber may reduce the amount of material potentially available for aquatic structure. Habitat for fish and aquatic organisms is created by woody debris altering channel morphology and through the dissipation of stream energy (Keller and Swanson 1979, Montgomery et al. 1995). Instream woody debris also plays critical roles in creating cover for fish (Tschaplinski and Hartman 1983), providing long-term food for aquatic organisms (Dudley and Anderson 1982), retaining transported sediment and organic matter (Bilby and Ward 1989), cycling of nutrients (Bilby and Likens1980) and providing substrate for aquatic invertebrates (Anderson et al 1984, Sedell et al. 1988). Woody debris also provides stable substrates for aquatic organisms such as bacteria (Triska et al. 1984), fungi (Shearer 1972), and invertebrates (Anderson et al. 1978, Benke et al. 1984), all of which decompose wood and represent major components of trophic webs in stream ecosystems.

Because all of these functions of woody debris influence the quality of food and habitat resources available to fish, changes in the abundance of woody debris in streams can be expected to induce changes in fish communities. Bisson and Sedell (1984) documented increases in riffle habitat, reductions in pool habitat, and declines in numbers of juvenile coho salmon 
(Oncorhynchus kisutch) in streams with smaller amounts of large woody debris (LWD).

Juvenile salmonids may also use the structural cover provided by LWD during certain times of the year (Bustard and Narver 1975a, 1975b, Tschaplinski and Hartman 1983, Heifetz et al. 1986, Swales et al. 1986). Habitat improvement procedures for salmonids often include installation of logs, tree branches, deflector structures, and small dams, which mimic effects of naturally occurring woody debris. Such manipulations can result in increased growth (Tarzwell 1938), survival (Gard 1961, Hunt 1971), and abundance (Boussu 1954, Saunders and Smith 1962, Burgess and Bider 1980) of fish. Adding artificial devices to a stream can increase carrying capacity for trout by providing better habitat (Saunders and Smith 1962, Hunt 1976, Hunt 1988) and thus is a popular technique in North America (Duff and Banks 1988).

The Appalachian region of the United States has a complex land use history involving multiple anthropogenic stresses to stream ecosystems. Chief among these is intensive timber harvest, both historical (Foster 1992) and present-day (Miller et al. 1998). The forests of West Virginia underwent widespread clear-cuts in the early $20^{\text {th }}$ century, and are now facing another wave of timber harvest as the forests once again reach maturity. Due to the prevalence of headwater streams, it is their riparian forests that are most likely to be harvested. Small, headwater (first- and second-order channels) (Strahler 1957) streams can account for 70-80\% of a total watershed area (Leopold et al. 1964, Gomi et al. 2002) and they supply water, organic matter, sediment and nutrients to downstream fish-bearing channels (Kiffney et al. 2000, Wipfli and Gregovich 2002, Volk et al. 2003). A management practice designed to minimize the impacts of forest harvest on aquatic systems, especially for resources such as water quality and fish habitat, entails leaving a strip of trees (riparian zone buffers) adjacent to the water body. Best management practices (BMP's) and streamside management zones (SMZ's) have been 
developed to minimize the impacts of riparian timber harvest. Within the U.S.A., actual guidelines and requirements vary by region and state (Lee et al. 2004). However, a common component of these guidelines is the establishment of a riparian buffer within which disturbance is limited. West Virginia BMP's require a SMZ that is at least $30 \mathrm{~m}$ wide (for perennial and intermittent streams) and is road-free (West Virginia Division of Forestry 2005). Trees can be harvested from the SMZ but the operation of large equipment in this area should be avoided. Within West Virginia, best management practices limit harvest of SMZ timber to 50\% of the basal area, although some timber companies employ stricter standards. West Virginia BMP's recognize that large woody debris in stream channels can be beneficial to aquatic life (West Virginia Division of Forestry 2005). However, in spite of this recognition, West Virginia BMP's also state that felled tree tops must be pulled from the stream channel on all perennial and intermittent streams, due to small logging debris possibly causing bank erosion and channel blockage (West Virginia Division of Forestry 2005). Following logging, proper reclamation techniques are to be applied, including seeding and mulching exposed soil. In a review of West Virginia's BMP's Kochenderfer et al. (1997) found that BMP's effectively protect streams.

Brook trout (Salvelinus fontinalis) are the only salmonid native to the Appalachians and are thought to have experienced substantial declines over the past century. They continue to be an important recreational resource and are an excellent biotic synthesizer of aquatic integrity for forested watersheds. Management of forested watersheds to maintain and even enhance water quality and this particular species are critical to sustainable forest management in this region. This project investigated the ecological effects of riparian harvest at moderate and high intensities, and the addition of LWD into streams on brook trout densities, growth, and size. The results of this study will help in the development of science-based recommendations for forest 
management and Best Management Practices that can be economically attractive to forest landowners. To date, studies of this nature have been conducted only once in the East, and never in the Appalachians.

\section{Methods}

\section{Study site description}

This study was conducted in eight tributaries of the Middle Fork River, Randolph County, West Virginia. The watershed is located in the Allegheny Plateau physiographic province. The study streams were Birch Fork (BF), Kittle Creek (KC), Mitchell Lick (ML), Rocky Run (RR), Schoolcraft Run (SCR), Mulberry Fork (MF), South Fork Panther Run (SPR) and North Fork Panther Run (NPR) (Figure 1). All streams were small, of low order, and relatively high gradient (Table 1). Stream elevations ranged from 685 to $929 \mathrm{~m}$. The pretreatment percent canopy cover of these streams averaged $80-90 \%$, and stream temperatures remained adequate for brook trout for the majority of the year with temperatures rarely exceeding $20^{\circ} \mathrm{C}$. The surrounding watersheds of all streams were actively managed for fiber production by the MeadWestvaco Corporation (property was sold to Penn Virginia Corporation in fall 2007), and timber harvest activities occurred in all watersheds throughout the study. The age of the surrounding forest ranged from 65 to 85 years and was dominated by yellow birch (Betula alleghaniensis), yellow poplar (Liriodendron tulipifera), black birch (Betula lenta), and sugar maple (Acer saccharum). All riparian areas were logged in the past with the greatest logging activity occurring in the early 1900's and sporadically since the 1930's. Timber harvest was restricted to $50 \%$ of the basal area of trees within SMZs. The width of the SMZs ranged from 15 to $50 \mathrm{~m}$ depending on slope with further guidelines that prohibited the operation of 
heavy machinery, and construction of logging roads. Instream crossings are permitted so long as the associated road enters and exits the SMZ in the shortest possible distance and a temporary culvert and sediment control devices are established (West Virginia Division of Forestry, 2005). Although limited harvest is permitted in SMZs, no such activity occurred along any of the streams during the course of the study except where designated. Evidence of prior timber harvest (all > 10 years before start of study) was apparent along all the steams with the presence of abandoned logging roads and railroad grades, stream crossings, and eroded stream banks in some areas.

All streams have had limestone sand added annually by the West Virginia Department of Natural Resources and the West Virginia Department of Environmental Protection since the mid 1990's. The underlying Pottsville geology has a very low buffering capacity; therefore limestone sand is added to mitigate the effects of acid precipitation and acid mine drainage to improve water quality in the mainstem of the Middle Fork River. Limestone is added by depositing a pile of sand on the streambank which is then swept into the stream under high flow events. This method of water quality enhancement has been successful in elevating stream $\mathrm{pH}$, increasing macroinvertebrate abundance, and restoring fish communities in West Virginia streams (Clayton and Menendez 1998, Clayton et al. 1998, McClurg et al. 2007).

Typical of Appalachian headwater streams, fish species diversity was low in all of the streams in this study. Brook trout was the dominant species. Other species found included mottled sculpin (Cottus bairdi) and blacknose dace (Rhinichthys atratulus).

The study began in January 2005, as eight candidate streams were chosen from eighteen streams within the Middle Fork River watershed in consultation with the MeadWestvaco regional timberlands manager (Aaron Plaugher) and MeadWestvaco Wildlife Ecosystem 
Research Forest manager (Dr. Patrick Keyser). Treatment streams were ultimately chosen based on a variety of criteria including: geology, presence of instream liming, stream order, total stream length, slope, recent timber harvest activities, presence of brook trout, and access. During the summer of 2005 pre-harvest instream habitat measurements were taken. In July 2006 commercial timber harvests commenced in the SMZs of the 8 streams. Timber harvest was finished at 7 of the streams by November 2006. Harvest on one stream (Kittle Creek) was not completed until March 2007.

\section{Experimental design}

Three-250 m study reaches (designated down, up, and reference reaches according to their relative position along the stream gradient) were established on each of the 8 streams and these reaches were separated by $100 \mathrm{~m}$ buffers (Figure 2). Each stream was then randomly assigned treatment to a $50 \%$ or a $90 \%$ removal (basal area), which remained undisturbed throughout the study (Table 2). The down and up sections were then randomly assigned to be either basal area removal (removal) treatment or basal area removal plus instream LWD addition (removal + LWD) treatment. Reference sites were always located upstream of the treatment sections, to eliminate potential impacts of the treatments. There was not a "true" control stream without any habitat manipulation, because stream to stream differences in habitat and brook trout abundance were greater than those within streams.

\section{Habitat assessment}

Stream fish abundance has been shown to be related to physical habitat (Neumann and Wildman 2002, Warren and Kraft 2003) as well as water quality (Gagen et al. 1994, Nilslow and 
Lower 2003) and as such, we sought to quantify these variables in our study. Habitat was surveyed during baseflow conditions according to a modified basinwide visual estimation technique BVET (Hankin and Reeves 1988, Dolloff et al. 1993, Simonson et al. 1994, Herger et al. 1996, Dolloff et al. 1997). Pre-harvest habitat data was assessed during baseflow conditions between 15 July and 30 July 2005. Post-harvest habitat data was assessed two times during baseflow conditions between 15 July and 2 August 2007, and again between 5 September and 15 2008. Individual habitat units were classified as pools, riffles, runs, or cascades according to criteria outlined in Arend (1999). Pools were considered areas of relatively low current velocity, greater depth, and laminar flow. Riffles were considered areas of lesser depth, greater current velocity, and broken water surfaces. Runs were considered areas where depth was shallower than pools; current velocity was greater than pools, but still maintained laminar flow and unbroken water surfaces. Cascades were considered areas with steep slope (> 7\%), high current velocity, and a stepped longitudinal profile, or areas that were a series of falls. If the habitat unit was a pool, the pool-forming mechanism was noted as boulder scour, LWD scour, bank scour, or freeform (Rosenfeld et al. 2000). Physical features measured in each habitat unit included length, wetted width, and water depths. The length of each habitat unit was measured along the thalweg (stream center) to the nearest $0.1 \mathrm{~m}$. Wetted and bankfull widths were visually estimated at transects established at $25 \%, 50 \%$, and $75 \%$ of the thalweg length. Depth was measured at three points along each transect to the nearest $\mathrm{cm}$. At every fifth habitat unit, the wetted and bankfull widths were both estimated and verified by measuring to the nearest $0.1 \mathrm{~m}$. The area of each habitat unit was estimated by multiplying the mean estimated wetted and/or bankfull width by its length. Estimated areas were then corrected by regression of verified area on estimated area and predicted values of the regression equation were used as the area of the habitat unit. 
Habitat unit areas were then summed by unit type to obtain an estimate of the total area of each unit type within each stream.

Several other habitat features were also inventoried within each basin. Percent canopy closure (Mills and Stevenson 1999) was estimated along the stream thalweg. In 2007, using benchmarks at the downstream reach of the study streams, canopy closure was estimated in each section with a digital camera (for records and count) approximately every $50 \mathrm{~m}$ along the stream thalweg. At each point a picture $(25 \times 20 \mathrm{~cm})$ of the overhead canopy was taken with a digital camera (Model: Hewlett Packard, HP photosmart 850, t 7.6- 61mm), with the camera fixed at a point $1 \mathrm{~m}$ off the ground. A 500 count grid $(1 \times 1 \mathrm{~cm})$ was then overlaid on the digital photo and percent of closed canopy cover was counted. An individual grid that had greater than $50 \%$ coverage of trees or leaves was considered a closed canopy grid. An individual grid that had less than $50 \%$ coverage of trees or leaves was considered an open canopy grid.

Large woody debris was considered any piece of wood with at least a portion within the bank full channel that could be wet under bank full flows, had a minimum mean diameter of 10 cm, and a minimum total length of $1.0 \mathrm{~m}$ (Overton et al. 1997). All LWD was inventoried based on estimated diameter and length classes. The minimum size was defined as $10 \mathrm{~cm}$ diameter and $1 \mathrm{~m}$ length, to account for all woody debris which may be large enough to serve as structure in defining small stream morphology (Richmond and Fausch 1995).

\section{Riparian tree removal and LWD additions}

Riparian tree removal and large woody debris additions began in July 2006 by 3 separate crews of loggers. Each logging crew was instructed to harvest trees within the SMZ as they normally would at any other site while abiding by West Virginia forestry BMPs. All trees felled 
within the removal only section were removed from the stream channel after harvesting. In the large woody debris addition section each logging crew was instructed to target 40 trees for felling in each reach. The trees selected for felling were spaced approximately every $15 \mathrm{~m}$ of stream Loggers felled one tree on each side of the stream with the hope that the two trees would anchor themselves to one another and create debris dams. Felled trees were selected based on size (> $10 \mathrm{~cm} \mathrm{dbh}$ ), and ultimately by the ease with which the loggers could fell the tree into the stream channel. In the removal plus large woody debris addition section, tree tops and branches that fell into the streams during harvest were left in place, so that they could create debris dams. Unlike previous studies, felled trees were not bucked so that the tree came in contact with the stream bed (Sweka 2003). The purpose of this study was to determine if normal timber harvesting techniques were able to increase instream habitat and productivity, as such we did not want extra time and effort spent by logging crews bucking logs as they normally would not do so during the course of typical riparian tree harvest.

\section{Brook trout population estimates}

Seasonal (March, June, August, November) population estimates of brook trout were based on sampling conducted in each reach of each stream in 2005 (pre-treatment), 2007 and 2008 (post-treatment). The entire $250 \mathrm{~m}$ stream reach of each section was sampled during each season. Block nets were placed at the upstream and downstream ends to meet the assumption of a closed population. Brook trout were captured using a pulsed DC backpack electrofishing unit and a two pass removal technique. Care was taken to ensure that all available habitats were electrofished on each pass. Brook trout from each pass were anesthetized in a $120 \mathrm{mg} \cdot \mathrm{L}-1$ solution of clove oil (Anderson et al. 1997), individually weighed to the nearest $0.5 \mathrm{~g}$, measured 
to the nearest $\mathrm{mm}$ total length, and released back into the area of capture following completion of the second electrofishing pass. Brook trout were separated into young-of-the-year and age 1+ age classes according to length frequency distributions.

Population estimates of trout were calculated using the Zippin method in order to determine population change, and estimate trout density (Zippin 1958). If fewer than 30 fish were captured, then the actual number of fish caught was substituted as an estimate (Riley and Fausch 1992). Fish density (fish/ $\mathrm{m}^{2}$ ) for each stream was then calculated as the mean population estimate divided by the mean wetted area $\left(\mathrm{m}^{2}\right)$ of the three sampling sections at base flow.

\section{Statistical Analysis}

\section{Brook trout populations}

Analysis of the effect of riparian tree removal and removal plus LWD additions on brook trout density was conducted in two steps. First, differences in age 1+ brook trout and YOY brook trout density between removal treatment prior to treatment were determined with a repeated measures analysis of variance (ANOVA) using the PROC MIXED procedure in SAS, where the removal type (50 and 90\%) and time (March, June, August, November 2005) were fixed effects and the stream within removal treatment was the random effect. For YOY brook trout, pre-treatment differences were determined only with June, August and November data. Following the timber harvest, differences in YOY and age 1+ brook trout density over time, and between removal types (removal + LWD vs. removal), were determined with repeated measures ANOVA using the PROC MIXED procedure in SAS. The percent basal area removal was used as a blocking factor, the removal type and time of sampling were fixed effects, and stream within removal type was the random subject effect. 
The effect of riparian tree removal and removal plus LWD addition upon brook trout size and condition was also examined. The mean total length of age 1+ and YOY brook trout for each stream was analyzed with a repeated measure ANOVA (PROC MIXED) in SAS to determine if pre-treatment total length was equal between sections. The percent basal area removal (50 and 90\%) and time (March, June, August, November) were fixed effects and stream within treatment was the random effect. For YOY brook trout, pre-treatment differences were determined only with June, August and November data. Post-treatment effects on size were analyzed in the same manner. In addition, we analyzed the removal + LWD section separately to determine LWD additions had an effect on brook trout size. Repeated measures ANOVA was used with treatment (removal + LWD vs. removal) and time as fixed effects, and streams as the random effect. For YOY brook trout, post-treatment differences were determined only with June, August and November data.

To assess a possible density-dependent size relationship, a repeated measures analysis of covariance (ANCOVA) was run on site-specific mean YOY length. We assumed that size would be temporally autocorrelated, thus mean length was regressed with density separately for June, August, and November samples. Initial model parameters included density, removal type, and a removal type-density interaction term. Mean fish size was regressed with mean density across all removal types to estimate the variation in mean size explained by density.

To determine post-treatment differences in age $1+$ brook trout condition over time and between removal types, we utilized relative weight as our condition factor. The relative weight (Wr ) equation as described by Wege and Anderson (1978) is:

$$
W r=\frac{W}{W s} * 100
$$


where $W=$ the actual weight of a fish, and $W s=$ the standard weight for a fish of the same length. The equation used to relate standard weight $(\mathrm{g})$ to total length (TL, mm) for brook trout was from Hyatt and Hubert (2001). The proposed metric ( $\mathrm{g}$ and $\mathrm{mm}$ ) standard weight equation for brook trout in lotic habitats is $\log _{10} W s=-5.186+3.103 \log _{10} \mathrm{TL}$. We did not assess condition on trout less than $120 \mathrm{~mm}$ following the suggestion by Hyatt and Hubert (2001). Mean relative weights were assessed using repeated measures ANOVA, which was used to determine the effect of removal type on brook trout condition. Treatment (removal + LWD vs. removal) and time were the fixed effects and stream reach within treatment was the random effect.

\section{Brook Trout Movement}

Movement into and out of a stream section was calculated in terms of percent retention and percent immigration. Percent retention was the number of fish captured in a stream section which were marked and had been released in the same stream reach on the previous sampling occasion. Percent immigration equaled the number of fish captured in a stream reach that did not possess any VIE tags, or a VIE tag not unique to the section of capture divided by the total number of fish collected (Sweka 2003). Overall percent retention of resident fish and percent immigrant fish were compared among sections using one-way ANOVA with 50\% and 90\% removal streams analyzed separately, and Fisher's least significant difference test was used as a multiple comparison test if the overall F-test was significant. 


\section{Results}

\section{Brook trout populations}

Pre-treatment YOY brook trout density varied across streams (Table 2) (50\% removal, p $=0.021: 90 \%$ removal, $\mathrm{p}=0.118$ ). Pre-treatment age $1+$ brook trout density also varied greatly across streams (Table 2) (50\% removal, $\mathrm{p}<0.001: 90 \%$ removal, $\mathrm{p}=0.085$ ).

Following the removal and removal plus addition of large woody debris, YOY brook trout densities varied significantly with time (Figure 3, 50\% removal, p < 0.001: Figure 4, 90\% removal, $\mathrm{p}<0.001)$. There was a small increase in YOY trout over time in some sections of the $50 \%$ removal streams, while the $90 \%$ removal streams also had increases in certain sections. After the removal and removal plus addition of large woody debris, age 1+ brook trout densities varied significantly with time (Figure 5, 50\% removal, $\mathrm{p}<0.001$ : Figure 6, 90\% removal, $\mathrm{p}<$ 0.001). There was not a consistent increase in age $1+$ trout over time in the $50 \%$ removal streams, while the $90 \%$ removal streams did have some increase in certain sections during early 2008.

There was no significant removal $\mathrm{x}$ time effect for YOY brook trout density in either the 50 or $90 \%$ removal streams (50\% removal, $\mathrm{p}=0.975: 90 \%$ removal, $\mathrm{p}=0.889$ ). There was also no significant removal $\mathrm{x}$ time effect for age $1+$ brook trout density $(50 \%$ removal, $\mathrm{p}=0.846$ : $90 \%$ removal, $\mathrm{p}=0.991)$ which would have indicated that there was a difference between removal, removal + LWD, and reference sites over time.

Fisher's LSD indicated that YOY brook trout density was significantly higher than reference in the removal + LWD section for the 50\% removal streams during June $2007(\mathrm{p}=$ 0.003). YOY brook trout density was not significantly different during any other post-harvest samples for the $50 \%$ removal streams (all $p>0.230$ ). Fisher's LSD indicated that YOY brook 
trout density was significantly higher than reference in the removal + LWD addition section $(\mathrm{p}=$ 0.003 ) and in the removal section $(\mathrm{p}=0.040)$ for the $90 \%$ removal streams during June 2007. Fisher's LSD indicated that YOY brook trout density was significantly higher than reference in the removal + LWD section $(\mathrm{p}=0.047)$ and in the removal section $(\mathrm{p}=0.030)$ for the $90 \%$ removal streams during August 2007. YOY brook trout density was not significantly different during any other post harvest samples for the $90 \%$ removal streams (all $p>0.068$ ).

Age $1+$ brook trout density was not significantly affected by treatments. Fisher's LSD indicated that age $1+$ brook trout density was not significantly higher in removal or removal + LWD sections compared to reference in the 50\% removal streams during any post harvest sample (all $\mathrm{p}>0.106)$. Fisher's LSD indicated that age $1+$ brook trout density was not significantly different in removal or removal + LWD than reference sites in the $90 \%$ removal streams during any post harvest sample (all $p>0.325$ ).

\section{Brook trout size and condition}

The riparian removal of trees and removal plus addition of LWD appeared to influence the size of some brook trout. Pre-treatment mean YOY total lengths $(\mathrm{p}=0.032)$ and age $1+$ total lengths $(\mathrm{p}=0.740)$ were similar between $50 \%$ and $90 \%$ removal streams. Following treatment, mean total lengths of YOY brook trout in both $50 \%$ and $90 \%$ removal streams varied significantly with time (Figure 7, 50\% removal, $\mathrm{p}<0.001$ : Figure 8, 90\% removal, $\mathrm{p}<0.001$ ). However, there were no differences between 50\% removal and 90\% removal streams $(\mathrm{p}=0.319)$ and there was no removal type $\mathrm{x}$ time interaction in either $50 \%$ or $90 \%$ removal streams $(50 \%$ removal, $\mathrm{p}=0.578: 90 \%$ removal, $\mathrm{p}=0.997$ ). Mean total length of YOY brook trout did vary across some streams and sections. Mean total length of YOY brook trout was greater in removal 
and removal + LWD sections of 50\% removal streams during June, August, and November 2007, and August 2008 but these differences were not significant. There were no differences in mean YOY brook trout total length between sections in the $90 \%$ removal streams during any sample. Analysis of covariance did not find a significant relationship between mean YOY density and YOY mean total length for any removal type in either $50 \%$ or $90 \%$ removal streams $($ all $\mathrm{p}>0.124)$.

Following removal and LWD addition, mean total lengths of age $1+$ brook trout in both $50 \%$ and $90 \%$ removal streams varied significantly with time (Figure 9, 50\% removal, $\mathrm{p}<0.001$ : Figure $10,90 \%$ removal, $\mathrm{p}<0.001)$. However, there were no differences between $50 \%$ removal and $90 \%$ removal streams $(\mathrm{p}=0.262)$ and there was no removal type $\mathrm{x}$ time interaction in either $50 \%$ or $90 \%$ removal streams $(50 \%$ removal, $\mathrm{p}=0.353: 90 \%$ removal, $\mathrm{p}=0.743)$. Mean total length of age $1+$ brook trout did vary across some streams and sections. Mean total length of age 1+ brook trout was higher than reference in removal and removal + LWD sections of 50\% removal streams during November $2007(\mathrm{p}=0.024)$. There were no differences in mean age $1+$ brook trout total length between sections in the $90 \%$ removal streams during any sample. The condition of age 1+ brook trout greater than $120 \mathrm{~mm}$, as indexed by relative weight, did not differ between $50 \%$ and $90 \%$ removal streams $(\mathrm{p}=0.762)$. The condition of age $1+$ brook trout did not differ between treatment (removal and removal + LWD) and reference reaches in $50 \%$ or $90 \%$ removal streams (Figure 11, 50\% removal, $\mathrm{p}=0.943:$ Figure 12, 90\% removal $\mathrm{p}=0.865$ )

\section{Brook trout movement.}

In the movement component of this study, a total of 11,213 brook trout were marked with VIE tags beginning in March 2007. The total number of recaptured brook trout was 3,500, thus 
$31.2 \%$ of the fish marked were recaptured in later samples. We found that few brook trout were recaptured outside of the stream section in which they were originally marked. The majority of brook trout, $87.8 \%$, were recaptured in the same stream reach. Of the $12.2 \%$ of brook trout that were captured outside of their original stream reach, they did not preferentially move into any particular section. Overall percent retention of resident fish differed significantly between sections $(\mathrm{p}=0.030)$. Percent retention was greatest in reference sections of $50 \%$ removal streams and lowest in the removal + LWD sections of 90\% removal streams (Table 3). Percent immigration was high in all sections (60-71\%) suggesting high rates of movement, but was not significantly different between sections (50\% removal streams, $\mathrm{p}=0.321$ : $90 \%$ removal streams, $p=0.256)$. Percent immigration was highest in the removal + LWD addition section $(71 \%)$ of the 50\% removal streams, while lowest in the reference section (60\%) of the 50\% removal streams.

\section{Discussion}

\section{Brook trout populations}

Previous researchers have reported increases in abundance of juvenile salmonids after clear-cut logging watersheds to the streambank (Bisson and Sedell 1984, Johnson et al. 1986, Murphy et al. 1986, Beschta et al. 1987, Thedinga et al. 1989, Bilby and Bisson 1992) with the increases in abundance of fish attributed to increases in abundance of prey that resulted from increased primary production. Several studies have shown a positive correlation between salmonid abundance and the amount of large woody debris in streams. Berg et al. (1998) and Fausch and Northcote (1992) both found that fish abundance was strongly correlated with total pool volume within a stream reach, which was governed by the amount of boulders and LWD in 
western streams. The occupancy rate of salmonids in a given habitat type increase with the amount of LWD (Flebbe and Dolloff 1995, Young 1996, Neumann and Wildman 2002). Brook trout abundance in small streams increase as pool areas increases (Gowan and Fausch 1996a, Neumann and Wildman 2002), and pool area has been shown to be influenced by the amount of LWD present (Richmond and Fausch 1995). In this before-after comparison study, in which we manipulated the amount of riparian tree harvest and LWD input, it was assumed that increasing the instream LWD would increase pool area and potentially increase brook trout abundance. While additional pools were not necessarily created in this study (Chapter 2), LWD additions within the stream also supplied other benefits to the stream by increasing retention of organic matter with potential increases in macroinvertebrate production, and the creation of overhead cover and refugia. These potential benefits associated with LWD addition could increase brook trout abundance through the retention of resident fish and attraction of immigrant fish.

YOY and age 1+ brook trout densities varied over the course of the study in both $50 \%$ and $90 \%$ removal streams. We found that in 2007 there was a large year class of YOY, with densities of YOY being greater in the removal and removal + LWD sections. The overall greater amount of LWD in these sections may have provided large areas of overhead cover and refugia for YOY brook trout, which may have increased the survival during summer, into fall and over winter. YOY densities were significantly higher in removal + LWD addition and removal sections in both treatments during both June and August 2007. The 90\% removal streams also had greater densities of YOY in November 2007 in the removal + LWD section but the differences were marginally significant (0.068). This age class of YOY fish may have had greater winter survival as age 1+ brook trout density was greater (but not significantly different) in March 2008 in removal + LWD and removal sections of both 50\% and 90\% removal streams. 
The removal and removal + LWD sections in $90 \%$ removal streams had continued higher densities (but not significantly different) of age 1+ fish during June 2008 as well. Sweka and Hartman (2006) found similar results in that fall densities of YOY were higher in streams that received greater amounts of LWD, and these higher densities carried over to the spring with higher densities of age 1+ brook trout. Conversely, Gowan and Fausch (1996a) did not find any influence of habitat manipulation on brook trout recruitment in Colorado. The high densities observed in both YOY and age 1+ brook trout was short lived as the densities were equivalent among sections in both treatments by November 2008. A similar trend in decreased densities was also observed by Sweka and Hartman (2006), who found that three years post LWD addition, sections with more LWD had similar brook trout densities to sections with less LWD by the end of the study.

While our study was a short-term study of riparian tree hravest effects on brook trout densities, it may be important to further monitor these sites to establish long-term observations on brook trout response to long-term harvest. Several of the studies that have reported increases in abundance of juvenile salmonids after clear-cut logging (Johnson et al. 1986, Murphy et al. 1986, Thedinga et al. 1989) were short-term studies that only sampled during one summer and one winter. Studies focused on trout population response to riparian timbering have either looked at the short-term effects (1 year or less), or the differences between a specific time period (35-50 year post harvest) and reference conditions, and were not a long-term monitoring and analysis. The lack of a multi-year study to assess the long-term response of salmonids to riparian harvest indicates the need to assess trends in brook trout populations over several years to document possible responses. In general, it is assumed that after riparian harvest, the short-term increase in salmonid production is followed by decreased productivity below natural levels, as 
the canopy closes and the physical habitat degrades. This pattern has been observed throughout the Pacific Northwest and provides a general model of how stream-dwelling salmonid populations respond to riparian logging (Murphy and Hall 1981, Hawkins et al. 1983, Bisson and Sedell 1984, Murphy et al. 1986, Beschta et al. 1987, Gregory et al. 1987, Bilby and Bisson 1992). While these studies have given a general pattern of salmonid population response to riparian logging, it is important to note that these studies in the Pacific Northwest involved different topography, geologies, and species than those in the our study and may yield different long-term results. To date, our study of brook trout response to manipulations of existing forest canopies and large woody debris additions within designated streamside management zones is the only one that has been conducted in the Appalachians and with this important recreational species. Future work should investigate the long term (5 - 30 year) changes in trout density, length, and condition associated with varying levels of timber harvest in these streams.

\section{Brook trout size and condition}

The removal of riparian trees and addition of LWD may have influenced the size of some brook trout. While the differences were not significant, mean total length of YOY brook trout was greater in removal and removal + LWD sections of 50\% removal streams during June, August, and November 2007, and August 2008, with no differences in 90\% removal streams. We found that age $1+$ brook trout condition and size were relatively unaffected by riparian harvest and harvest plus the addition of LWD. Mean total length of age $1+$ brook trout was higher in removal and removal + LWD sections of 50\% removal streams only during November 2007 with no differences in $90 \%$ removal streams. The condition of age $1+$ brook trout did not differ between treatment and reference reaches in $50 \%$ or $90 \%$ removal streams. LWD increases 
the storage of leaf matter (Raikow et al. 1995) which provides substrate and food resources for aquatic macroinvertebrates, thereby increasing the potential for production at higher trophic levels (Gurnell et al. 1995). Thus, condition and size would be expected to be greatest in areas with abundant LWD, which was somewhat the case for YOY in 50\% removal streams. It is possible that increases in the density of trout within these sections may have affected condition and growth. Increases in the density of YOY and age 1+ trout may have offset the gains in productivity and yielded non-significant differences in the size or condition of trout. Riparian harvest increases primary productivity, increases benthic invertebrates, resulting in an increase in juvenile salmonid density and growth (Bisson and Sedell 1984, Beschta et al. 1987, Bilby and Bisson 1992). We would expect condition and size to be greatest in areas with the most removal (90\% removal), but no such effect was seen. Although LWD additions were lower than ours, Sweka (2003) found age 1+ brook trout growth, condition, and size were unaffected by LWD additions in central Appalachian streams. Other researchers have also failed to show a relationship between increased LWD abundance and growth of salmonids. Cederholm et al (1997) found that LWD additions did not increase the mean length of coho salmon smolts. Several studies by Fausch, did not show any influence of LWD additions to brook trout growth and condition in Colorado streams (Riley and Fausch 1995, Gowan and Fausch 1996a). Adding LWD to streams has the potential to increase food availability to fish, but this increased food availability could be offset by decreased foraging efficiency due to increased instream overhead cover (Wilzbach and Cummins 1986). Stream dwelling salmonids prefer areas with abundant cover and decreased risk of predation provided by LWD (Young 1995, Flebbe and Dolloff 1995, Neuman and Wildman 2002) and may not have preference for areas where energy acquisition is maximized because of low overhead cover and increased predation risk. Therefore, there are 
costs and benefits associated with our treatment sections, and fish may have to adjust habitat use and foraging behavior so as to balance these.

\section{Brook trout movement.}

We found few brook trout were recaptured outside of the stream section in which they were originally marked. The high percentage of brook trout $(87.8 \%)$ recaptured in their original location, suggests that movement rates between sections was low (Gerking 1959), or that moving fish moved on a scales greater than the reach scale. Sweka (2003) in studying central Appalachian streams also found a high percentage of recaptured fish in their original location of capture (86\%). However, this may not be evidence of low movement (Gowan and Fausch (1996b). At the same time, percent immigration was high in all sections (60-71\%) suggesting high rates of movement (Gowan and Fausch 1996b). Sweka (2003) also found a high percentage of immigration (73-91\%) within central Appalachian streams. Our study results are somewhat similar to other studies of stream fish movement, having low recapture rates and high

percentages of immigrant fish (Gowan et al. 1994, Sweka 2003). However, we had much higher percentage retention of resident fish than other studies, where retention was $34-58 \%$. Sweka found that retention of brook trout was much lower (7-25\%) in central Appalachian streams. Percent retention was greatest in reference sections of 50\% removal streams and lowest in the removal + LWD sections of $90 \%$ removal streams. Based on several behavioral studies, it appears that several species of stream dwelling salmonids prefer pool habitat with abundant LWD cover (Young 1995, Flebbe and Dolloff 1995, Neuman and Wildman 2002). Retention of resident fish would be expected to be greatest in these areas, but this was not the case. A possible explanation for these results may be that if fish move within these streams they move 
greater distances than the reach levels we studied, and if fish do not move, they stay within their chosen reach.

We did not study the movement of fish in the $100 \mathrm{~m}$ buffer sections above and below the study sections nor in other areas of the stream. Trout could have been opportunistically moving the relatively short distances into the study sections from these areas. Previous research has shown that very large movements are common and that immigrating fish came from beyond the stream study sections. Sweka (2003) suggested that the high rates of movement (immigration) seen in central Appalachian streams is most likely due to fish moving relatively short distances $(<400 \mathrm{~m})$. Logan (2003) suggests that brook trout in Appalachian headwater streams are quite mobile with brook trout having a mean spring season home range of 301- $637 \mathrm{~m}$. Young (1995), Harvey (1998), and Gowan and Fausch (1996b) also found large amounts of movement by trout. One possible explanation for the high rates of movement is that our mark-recapture periods were spaced too far apart. If small movements are constantly taking place, the long duration (3 months) between sampling in our study reduced the probability of recapturing a fish in its home section. If we had increased sampling periods, immigration rates may likely have been lower. However, the increased electrofishing effort and the potential effects on trout survival (Dalbey et al. 1996) could have biased conclusions.

\section{Best management practices and brook trout}

States have created BMP guidelines pertaining to SMZ widths based on several different factors such as slope, stream width, stream type, stream order, and land use (cold water fisheries, municipal waters, wetlands). West Virginia, along with several southeastern U.S. states, allows timber harvesting within SMZs. Overall, most southeastern states recommend leaving 50-75\% 
canopy cover or $50 \mathrm{ft}^{2} /$ acre basal area on perennial streams. West Virginia has no current harvesting restriction within the streamside management zone. While West Virginia has not adopted harvesting limits within SMZ's, some timber companies have employed their own harvest limits. For instance, MeadWestvaco Corporation restricts timber harvest to $50 \%$ of the basal area within SMZ's. (Aaron Plaugher, Personal Communication).

Limits on harvest of timber in the southeastern U.S. vary by state; however we could find no studies that actually quantify the impacts of different harvest limits in SMZ's on brook trout. Kentucky and Georgia recommend leaving 50-75\% canopy cover on streams with cold water fisheries (Kentucky Department of Forestry 1997, Georgia Forestry Commission 1999). Georgia sets forth two specific harvest practice options for trout streams: Option A) A minimum 100 feet SMZ that includes a no harvest zone within the first 25 feet of primary or secondary trout streams, timber harvests within the remaining 75 feet of the SMZ should leave an average of 50 square $\mathrm{ft}$ of basal area per acre or at least 50\% canopy cover. Option B) Within the 100 feet SMZ, leave an average of 50 square feet of basal area per acre evenly distributed throughout the zone to provide shade (Georgia Forestry Commission 1999). Kentucky recommends that coldwater streams should have a minimum of 75 percent of the original tree overstory retained within the 60-foot-wide strip on either side of the stream (Kentucky Department of Forestry 1997). We found that timber harvest with SMZ's had some positive effect on fish as YOY densities were greater in the removal section in both $50 \%$ and $90 \%$ removal streams during summer 2007. We also found a corresponding increase in age 1+ brook trout density in March 2008 in both treatments. However, the high densities observed in YOY trout were short-lived as the densities were equivalent among sections in 90\% treatments in August 2008 and in 50\% treatments by November 2008. The higher densities observed in and age $1+$ brook trout was also 
short-term as the densities were equivalent among sections in 90\% treatments in August 2008 and in 50\% treatments by June 2008. The decreases seen from June to August 2008 in age 1+ trout in the $90 \%$ streams may suggest avoidance by trout of the removal sections during periods of increased temperatures. The further decrease in age 1+ trout density from August to November 2008 in the $90 \%$ streams could also indicate decreased summer survival within these sections. We found that $50 \%$ removal sections did not have the large decreases in age $1+$ fish from June to August 2008 and actually had increased for YOY trout in these sections during this time. Further, the mean total length of YOY brook trout was greater in removal sections of 50\% removal streams during June, August, and November 2007, and August 2008, with no differences in $90 \%$ removal streams. Our results suggest that $50 \%$ basal area removal of trees within an SMZ has no negative effect on brook trout and in some cases may be beneficial. We suggest that coldwater streams should have a minimum of 50 percent of the basal area retained within the SMZ. However, the short-term (year 1) increase and then subsequent decrease (year 2) in brook trout densities make it necessary to assess trends in brook trout populations over several years as there are several unknowns associated with the possible response to varying riparian harvest.

Current BMP's require that all logging debris be removed from streams during timber operations. Currently, felled tops must be pulled from the stream channel on all perennial and intermittent streams, as small logging debris can be harmful to the stream channel causing bank erosion and channel blockage (West Virginia Division of Forestry 2005). We found that timber harvest combined with LWD addition with SMZ's had some positive effect on fish as YOY densities were greater in LWD addition section in both 50\% and 90\% removal streams during summer 2007. We also found a corresponding increase in age 1+ brook trout density in March 
2008 in these same areas. However, the high densities observed in YOY trout were short-lived as the densities were equivalent among sections in 90\% treatments in August 2008 and in 50\% treatments by November 2008. The higher densities observed in age 1+ brook trout were also short-term as the densities were equivalent by August 2008. We found that mean total length of YOY brook trout was greater in LWD addition sections of $50 \%$ removal streams during June, August, and November 2007, and August 2008, with no differences in 90\% removal streams. Our results suggest that the addition of LWD and tree tops to a stream has no negative effect on brook trout and in some cases were beneficial. However, it is necessary to assess possible trends in brook trout populations over several years as the full potential of the added LWD to affect brook trout populations may not be realized for many more years. 


\section{References}

Anderson, N. H., J. R. Sedell, L. M. Roberts, and F. J. Triska. 1978. The role of aquatic invertebrates in processing wood debris in coniferous forest streams. American Midland Naturalist 100:64-82.

Anderson, N. H., R. J. Steedman, and T. Dudley. 1984. Patterns of exploitation by stream invertebrates of wood debris (xylophagy). Verhandlungen der Internationalen Vereinigung fur Theoretische und Angewandte Limnologie 22:1847-1852.

Anderson, N. H. 1992. Influence of disturbance on insect communities in Pacific northwest streams. Hydrobiologia 248:79-92.

Anderson, W. G., R. S. McKinley, and M. Colavechia. 1997. The use of clove oil as an anesthetic for rainbow trout and its effects on swimming performance. North American Journal of Fisheries Management 17:301-307.

Arend, K. K. 1999. Stream reach surveys and measurements. Pages 47-56 in M. B. Bain and N. J. Stevensen, editors. Aquatic habitat assessment: common methods. American Fisheries Society, Bethesda, Maryland.

Benke, A. C., T. C. Van Arsdall, Jr., and D. M. Gillespie. 1984. Invertebrate productivity in a subtropical blackwater river: the importance of habitat and life history. Ecological Monographs 54:25-36.

Berg, N., A. Carlson, and D. Azuma. 1998. Function and dynamics of woody debris in stream reaches in the central Sierra Nevada California. Canadian Journal of Fisheries and Aquatic Sciences 55:1807-1820.

Beschta, R. L. 1997. Riparian shade and stream temperature: an alternative perspective. Rangelands 19:25-28.

Beschta, R. L., R. E. Bilby, G. W. Brown, L. B. Holtby, and T. D. Hofstra. 1987. Stream temperature and aquatic habitat: fisheries and forestry interactions. Pages 191-232 in E. O. Salo, and T. W. Cundy, editors. Streamside management: Forestry and fishery interactions. Institute of Forest Resources, University of Washington, Seattle.

Bilby, R. E., and G. E. Likens. 1980. Importance of organic debris dams in the structure and function of stream ecosystems. Ecology 61:1107-1113.

Bilby, R. E., and J. W. Ward. 1989. Changes in characteristics and function of woody debris with increasing size of streams in western Washington. Transactions of the American Fisheries Society 18:368-378. 
Bilby, R. E., and P. A. Bisson. 1992. Allochthonous versus autochthonous organic matter contributions to the trophic support of fish populations in clear-cut and old-growth forested watersheds. Canadian Journal of Fisheries and Aquatic Sciences 49:540-551.

Bisson, P. A., and J. R. Sedell. 1984. Salmonid populations in streams in clear-cut vs. old-growth forests of western Washington. Pages 121-130 in W. R. Meehan, T. R. Merrell, Jr., and T. A. Hanley, editors. Proceedings, fish and wildlife relationships in old growth forests symposium. American Institute of Fishery Research Biologists, Asheville, North Carolina.

Bisson, P. A., T. P. Quinn, G. H. Reeves, and S. V. Gregory. 1992. Best management practices, cumulative effects, and long-term trends in fish abundance in Pacific Northwest river systems. Pages 189-232 in R. J. Naiman, editor. Watershed management: balancing sustainability and environmental change. Springer-Verlag, New York.

Boss, S. M., and J. S. Richardson. 2002. The effects of food and cover on the growth, survival, and movement of cutthroat trout in coastal streams. Canadian Journal of Fisheries and Aquatic Sciences 59:1044-1053.

Boussu, M. F. 1954. Relationship between trout populations and cover on a small stream. The Journal of Wildlife Management 18:229-239.

Brosofske, K. D., J. Chen, R. J. Naiman, and J. F. Franklin. 1997. Harvesting effects on microclimatic gradients from small streams to uplands in western Washington. Ecological Applications 7:1188-1200.

Burgess, S. A., and J. R. Bider. 1980 Effects of stream habitat improvements on invertebrates, trout populations, and mink activity. The Journal of Wildlife Management 44:871-880.

Burns, J. W. 1972. Some effects of logging and associated road construction on northern California streams. Transactions of the American Fisheries Society 101:1-17.

Bustard, D. R., and D. W. Narver. 1972a. Aspects of the winter ecology of juvenile coho salmon (Oncorhynchus kisutch) and steelhead trout (Salmo gairdneri). Journal of the Fisheries Research Board of Canada 32:667-680.

Bustard, D. R., and D. W. Narver. 1972b. Preferences of juvenile coho salmon (Oncorhynchus kisutch) and cutthroat trout (Salmo clarki ) relative to simulated alteration of winter habitat. Journal of the Fisheries Research Board of Canada 32:681-687.

Cada, G. F., J. M. Loar, and M. J. Sale. 1987. Evidence of food limitation of rainbow and brown trout in southern Appalachian soft-water streams. Transactions of the American Fisheries Society 116:692-702.

Cederholm, C. J., R. E. Bilby, P. A. Bisson, T. W. Bumstead, B. R. Fransen, W. J. Scarlett, and 
J. W. Ward. 1997. Response of juvenile coho salmon and steelhead to placement of large woody debris in a coastal Washington stream. North American Journal of Fisheries Management 17:947-963.

Chamberlin, T. W., R. D. Harr, and F. H. Everest. 1991. Timber harvesting, silviculture, and watershed processes. Pages 181-206 in W. R. Meehan, editor. Influences of forest and rangeland management on salmonid fishes and their habitats. American Fisheries Society Special Publication 19, Bethesda, Maryland.

Clayton, J. L., E. S. Dannaway, R. Menendez, H. W. Rauch, J. J. Renton, S. M. Sherlock, and P. E. Zurbuch. 1998. Application of limestone to restore fish communities in acidified streams. North American Journal of Fisheries Management 18:347-360.

Clayton, J. L. and R. Menendez. 1998. Macroinvertebrate response to instream applications of fine grained limestone to mitigate acid deposition. USFWS progress report.

Cummins, K. W. 1974. Structure and function of stream ecosystems. BioScience 24:631-641.

Cummins, K. W., G. W. Minshall, J. R. Sedell, C. E. Cushing, and R. C. Petersen. 1984. Stream ecosystem theory. Mitteilungen der Internationalen Vereinigung fur Theoretische und Angewandte Limnologie 22:1818-1827.

Dalbey, S. R., T. E. McMahon, and W. Fredenberg. 1996. Effect of electrofishing pulse shape and electrofishing-induced spinal injury on long-term growth and survival of wild rainbow trout. North American Journal of Fisheries Management 16:560-569.

Davies, P. E., and M. Nelson. 1994. Relationship between riparian buffer widths and the effects of logging on stream habitat, invertebrate community composition, and fish abundance. Australian Journal of Marine and Freshwater Research 45:1289-1305.

Dolloff, C. A. 1986. Effects of stream cleaning on juvenile coho salmon and Dolly Varden in southeast Alaska. Transactions of the American Fisheries Society 115:743-755.

Dolloff, C. A., D. G. Hankin, and G. H. Reeves. 1993. Basinwide estimation of habitat and fish populations in streams. Southeastern Forest Experimental Station. Ashville, North Carolina.

Dolloff, C. A., H. E. Jennings, and M. D. Owen. 1997. A comparison of basinwide and representative reach habitat survey techniques in three southern Appalachian watersheds. North American Journal of Fisheries Management 17:339-347.

Duncan, W. F. A., and M. A. Brusven. 1990. Benthic macroinvertebrates in logged and unlogged low-order southeast Alaskan streams. Freshwater Invertebrate Biology 4:125-132.

Dudley, T. L., and N. H. Anderson. 1982. A survey of invertebrates associated with wood debris in aquatic habitats. Melanderia 39:1-21. 
Duff, D. A., and N. Banks. 1988. Indexed bibliography on stream habitat improvement. U.S. Forest Service. Intermountain Region. Ogden, Utah.

Elliott, S. T. 1986. Reduction of a Dolly Varden population and macrobenthos after removal of logging debris. Transactions of the American Fisheries Society 115:392-400.

Fausch, K. D., and T. G. Northcote. 1992. Large woody debris and salmonid habitat in a small coastal British Columbia stream. Canadian Journal of Fisheries and Aquatic Sciences 49:682-693.

Flebbe, P. A., and C. A. Dolloff. 1995. Trout use of woody debris and habitat in Appalachian wilderness streams of North Carolina. North American Journal of Fisheries Management 15:579-590.

Foster, D. R., 1992. Land-use history (1730-1990) and vegetation dynamics in central New England, USA. Journal of Ecology 80:753-772.

Fuller, R. L., J. L. Roelofs, and T. F. Fry. 1986. The importance of algae to stream invertebrates. Journal of the North American Benthological Society 5:290-296.

Gagen, C. J., W. E. Sharpe, and R. F. Carline. 1994. Downstream movement and mortality of brook trout (Salvelinus fontinalis) exposed to acidic episodes in streams. Canadian Journal of Fisheries and Aquatic Sciences 51:1620-1628.

Gard, R. 1961. Effects of beaver on trout in Sagehen Creek, California Journal of Wildlife Management 25:221-242.

Garman, G. C. and J. R. Moring 1991. Initial effects of deforestation on physical characteristics of a boreal river. Hydrobiologia 209:29-37.

Georgia Forestry Commission. 1999. Best management practices for forestry. GFC, Macon. GA. 8-13.

Gerking, S. D. 1959. The restricted movement of fish populations. Biological Reviews Cambridge Philosophical Society 34:221-242.

Gomi, T., R. C. Sidle, and J. S. Richardson. 2002. Headwater and network systems: understanding processes and downstream linkages of headwater systems. Biosciences 52:905-916.

Gowan, C., M. K. Young, K. D. Fausch, and S. C. Riley. 1994. Restricted movement in stream resident salmonids: a paradigm lost? Canadian Journal of Fisheries and Aquatic Sciences 74:2626-2637. 
Gowan, C., and K. D. Fausch. 1996a. Long-term demographic responses of trout populations to habitat manipulation in six Colorado streams. Ecological Applications 6:931-946.

Gowan, C., and K. D. Fausch. 1996b. Mobile brook trout in two high-elevation Colorado streams: reevaluation of the concept of restricted movement. Canadian Journal of Fisheries and Aquatic Sciences 53:1370-1381.

Gregory, S. V., G. A. Lamberti, D. C. Erman, K. V. Koski, M. L. Murphy, and J. R. Sedell. 1987. Influence of forest practices on aquatic production. Pages 234-255 in E. O. Salo and T. W. Cundy, editors. Streamside management: Forestry and fishery interactions. Proceedings of a Symposium. Institute of Forest Resources, University of Washington, Seattle.

Gurnell, A. M., K. J. Gregory, and G. E. Petts. 1995. The role of coarse woody debris in forest aquatic habitats: implications for management. Aquatic Conservation: Marine and Freshwater Ecosystems 5:143-166.

Gurtz, M. E., and J. B. Wallace. 1984. Substrate-mediated response of stream invertebrates to disturbance. Ecology 65:1556-1569.

Hankin, D. G., and G. H. Reeves. 1988. Estimating total fish abundance and total habitat area in small streams based on visual estimation methods. Canadian Journal of Fisheries and Aquatic Sciences 41:1575-1591.

Harding, J. S., E. F. Benfield, P. V. Bolstad, G. S. Helfman, and E. B. D. Jones. 1998. Stream biodiversity; the ghost of land use past. Proceedings of the National Academy of Sciences 95:14834-14847.

Hartman, G. F., J. C. Scrivener, and M. J. Miles. 1996. Impacts of logging in Carnation Creek, a high-energy coastal stream in British Columbia, and their implications for restoring fish habitat. Canadian Journal of Fisheries and Aquatic Sciences 53:237-251.

Harvey, B. 1998. Influence of large woody debris on retention, immigration, and growth of coastal cutthroat trout (Oncorhynchs clarki clarki) in stream pools. Canadian Journal of Fisheries and Aquatic Sciences 55:1902-1908.

Hawkins, C. P., M. L. Murphy, N. H. Anderson, and M. A. Wilzbach. 1983. Density of fish and salamanders in relation to riparian canopy and physical habitat in streams of the northwestern United States. Canadian Journal of Fisheries and Aquatic Sciences 40:11731185.

Heifetz, J., M. L. Murphy, and K. V. Koski. 1986. Effects of logging on winter habitat of juvenile salmonids in Alaska streams. North American Journal of Fisheries Management 6:52-58.

Herger, L. G., W. A. Hubert, and M. K. Young. 1996. Comparison of habitat composition and 
cutthroat trout abundance at two flows in small mountain streams. North American Journal of Fisheries Management 16:294-301.

Hetrick, N. J., M. A. Brusven, W. R. Meehan, and T. C. Bjornn. 1998. Changes in solar input, water temperature, periphyton accumulation, and allochthonous input and storage after canopy removal along two small salmon streams in southeast Alaska. Transactions of the American Fisheries Society 127:859-875.

Hunt, G. L. 1971. Response of a brook trout population to habitat development in Lawrence Creek. Wisconsin Department of Natural Resources, Technical Bulletin 48. Madison.

Hunt, R. L. 1976. A long-term evaluation of trout habitat development and its relation to improving management-related research. Transactions of the American Fisheries Society 105:361-364.

Hunt, R. L. 1988. A compendium of 45 trout stream habitat development evaluations in Wisconsin during 1953-1985. Wisconsin Department of Natural Resources Technical Bulletin 162.

Hyatt, M. W. and W. A. Hubert. 2001. Proposed standard-weight equations for brook trout. North American Journal of Fisheries Management 21:253-254.

Johnson, S. W., J. Heifetz, and K. V. Koski. 1986. Effects of logging on the abundance and seasonal distribution of juvenile steelhead in some southeastern Alaska streams. North American Journal of Fisheries Management 6:532-537.

Keller, E. A., and F. J. Swanson. 1979. Effects of large organic material on channel form and fluvial processes. Earth Surface Processes 4:361-380.

Kentucky Department of Forestry. 1997. Field guide to best management practices for timber harvesting. Kentucky Department of Forestry, Lexington. Kentucky.

Kiffney, P. M., J. S. Richardson, and M. C. Feller. 2000. Fluvial and epilithic organic matter dynamics in headwater streams of southwestern British Columbia, Canada. Archiv fur Hydrobiologie 149:109-129.

Kiffney, P. M., J. S. Richardson, and J. P. Bull. 2003. Responses of periphyton and insects to experimental manipulation of riparian buffer width along forest streams. Journal of Applied Ecology 40:1060-1076.

Kochenderfer, J. N., P. J. Edwards, and F. Wood. 1997. Hydrologic impacts of logging an Appalachian watershed using West Virginia's best management practices. Northern Journal of Applied Forestry 14:207-218.

Lee, P., C. Smyth, and S. Boutin. 2004. Quantitative review of riparian buffer width guidelines from Canada to the United States. Journal of Environmental Management 70:165-180. 
Leopold, L. B., M. G. Wolman, and J. P. Miller. 1964. Fluvial Processes in Geomorphology. Dover Publications, New York.

Logan, M. N. Brook trout (Salvelinus fontinalis) movement and habitat use in a headwater stream of the central Appalachian Mountains of West Virginia. Master's Thesis. West Virginia University, Morgantown.

Lowe, R. L., S. W. Golladay, and J. R. Webster. 1986. Periphyton response to nutrient manipulation in streams draining clearcut and forested watersheds. Journal of the North American Benthological Society 5:221-229.

McClurg, S. E. 2004. Stream ecosystem response to mitigative limestone treatment in acid impaired, Central Appalachian streams. Master's Thesis. West Virginia University, Morgantown.

Miller, E .L., R. S. Beasley, and E. R. Lawson. 1988. Forest harvest and site preparation effects on stormflow and peakflow of ephemeral streams in the Ouachita Mountains. Journal of EnvironmentalQuality 17:212-218.

Mills, K. E., and N. J. Stevenson. 1999. Riparian Vegetation. Pages 125-134 in M. B. Bain and N. J. Stevensen, editors. Aquatic habitat assessment: common methods. American Fisheries Society, Bethesda, Maryland.

Minshall, G. W. 1978. Autotrophy in stream ecosystems. BioScience 28:767-771.

Montgomery, D. R., J. M. Buffington, R. Smith, K. M. Schmidt, and G. Pess. 1995. Pool spacing in forest channels. Water Resources Research 31:1097-1105.

Murphy, M. L., and J. D. Hall. 1981. Varied effects of clear-cut logging on predators and their habitat in small streams of the Cascade Mountains, Oregon. Canadian Journal of Fisheries and Aquatic Sciences 38:137-145.

Murphy, M. L., C. P. Hawkins, and N. H. Anderson. 1981. Effects of canopy modification and accumulated sediment on stream communities. Transactions of the American Fisheries Society 110:469-478.

Murphy, M. L., J. Heifetz, S. W. Johnson, K. V. Koski, and J. F. Thedinga. 1986. Effects of clear-cut logging with and without buffer strips on juvenile salmonids in Alaskan streams. Canadian Journal of Fisheries and Aquatic Sciences 43:1521-1533.

Naiman, R. J., K. L. Fetherston, S. J. McKay, and J. Chen. 1998. Riparian forests. Pages 289-323 in R. J. Naiman, and R. E. Bilby, editors. River ecology and management SpringerVerlag, New York. 
Narver, D. W. 1971. The effect of logging debris on fish production. in Proceedings of a symposium, forest land uses and stream environment. School of Forestry and Department of Fisheries and Wildlife, Oregon State University, Corvallis.

Neumann, R. M., and T. L. Wildman. 2002. Relationships between trout habitat use and woody debris in two southern New England streams. Ecology of Freshwater Fish 11:240-250.

Newbold, J. D., D. C. Erman, and K. B. Roby. 1980. Effects of logging on macroinvertebrates in streams with and without buffer strips. Canadian Journal of Fisheries and Aquatic Sciences 37:1076-1085.

Nilslow, K. H., and W. H. Lowe. 2003. Influences of logging history and stream pH on brook trout abundance in first-order streams in New Hampshire. Transactions of the American Fisheries Society 132:166-171.

Osmundson, D. B., R. J. Ryel, V. L. Lamarra, and P. Pitlick. 2002. Flow-sediment-biota relations: implications for river regulation on native fish abundance. Ecological Applications 12:1719-1739.

Overton, C. K., S. P. Wollrab, B. C. Roberts, and M. A. Radko, 1997. R1/ R4 (Northern/Intermountain Regions) fish and fish habitat standard inventory procedures handbook. General Technical Report INT-GTR-346 Intermountain Research Station, Ogden, Utah.

Platts, W. S., and W. F. Megahan. 1975. Time trends in riverbed sediment composition in salmon and steelhead spawning areas: South Fork Salmon River, Idaho. Transactions of the North American Wildlife Natural Resource Conference 40:229-239.

Pollock, M. M. 1998. Biodiversity. Pages 423-454 in R. J. Naiman, and R. E. Bilby, editors. River Ecology and Management Springer-Verlag, New York.

Raikow, D. F., S. A. Grubbs, and K. A. Cummins. 1995. Debris dam dynamics and coarse particulate matter retention in an Appalachian Mountain stream. Journal of the North American Benthological Society 14:535-546.

Reeves, G. R., F. H. Everest, and J. R. Sedell. 1993. Diversity of juvenile anadromous salmonid assemblages in coastal Oregon basins with different levels of timber harvest. Transactions of the American Fisheries Society 122:309-317.

Richardson, B. A. 1985. The impact of forest road construction on the benthic invertebrate and fish fauna of a coastal stream in southern New South Wales. Australian Society for Limnology Bulletin 10:65-88.

Richmond, A. D. and K. D. Fausch. 1995. Characteristics and function of large woody debris in subalpine Rocky Mountain stream in northern Colorado. Canadian Journal of Fisheries and Aquatic Sciences 52:1789-1802. 
Riley, S. C., and K. D. Fausch. 1992. Underestimation of trout populations size my maximum likelihood removal estimate in small streams. North American Journal of Fish Management 12:768-776.

Rosenfeld, J., M. Porter, and E. Parkinson. 2000. Habitat factors affecting the abundace and distribution of juvenile cutthroat trout (Oncorhynchus clarki) and coho salmon (Oncorhynchus kisutch). Canadian Journal of Fisheries and Aquatic Sciences 57:766-774.

Saunders, J. W., and M. W. Smith. 1962. Physical alterations of stream habitat to improve brook trout production. Transactions of the American Fisheries Society 91:185-188.

Sedell, J. R., P. A. Bisson, F. J. Swanson, and S. V. Gregory. 1988. What we know about large trees that fall into streams and rivers. Pages 47-81 in C. Maser, R. F. Tarrant, J. M. Trappe, and J. F. Franklin, technical editors. From the forest to the sea: a story of fallen trees. General Technical Report PNW-GTR-229. U.S. Forest Service, Pacific Northwest Research Station, Portland.

Shearer, C. A. 1972. Fungi of the Chesapeake Bay and its tributaries III. The distribution of wood-inhabiting Ascomycetes and fungi imperfecti of the Patuxent River. American Journal of Botany 59:961-969.

Sheridan, W. L., and W. J. McNeil. 1968. Some effects of logging on two salmon streams in Alaska. Journal of Forestry 66:128-133.

Simonson, T. D., J. Lyons, and P. D. Kanehl. 1994. Quantifying fish habitat in streams: transect spacing, sample size, and a proposed framework. North American Journal of Fisheries Management 14:607-615.

Stone, M. K., and J. B. Wallace. 1998. Long-term recovery of a mountain stream from clear-cut logging: the effects of forest succession on benthic invertebrate community structure. Freshwater Biology 39:151-169.

Strahler, A. N. 1957. Quantitative analysis of watershed geomorphology. Transactions of the American Geophysical Union, 38:913-920.

Swales, S., R. B. Lauzier, and C. D. Levings. 1986. Winter habitat preferences of juvenile salmonids in two interior rivers in British Columbia. Canadian Journal of Zoology 64:1506-1514.

Sweka, J. A. 2003. Aquatic-terrestrial linkages in Appalachian streams: influence of riparian inputs on stream habitat, brook trout populations, and trophic dynamics. Ph.D. dissertation, West Virginia University, Morgantown.

Sweka. J. A., and K. J. Hartman. 2006. Effects of large woody debris addition on stream habitat and brook trout populations in Appalachian streams. Hydrobiologia 559:363-378. 
Tarzwell, C. M. 1938. Factors influencing fish food and fish production in southwestern streams. Transactions of the American Fisheries Society 67:246-255.

Thedinga, J. F., M. L. Murphy, J. Heifetz, K. V. Koski, and S. W. Johnson. 1989. Effects of logging on size and age composition of juvenile coho salmon (Oncorhynchus kisutch) and density of presmolts in southeast Alaska streams. Canadian Journal of Fisheries and Aquatic Sciences 46:1383-1391.

Toews, D. A. A., and M. K. Moore. 1982a. The effects of three streamside logging treatments on organic debris and channel morphology of Carnation Creek. Pages 129-153 in G. F. Hartman, editor. Proceedings of the Carnation Creek workshop: a ten-year review. Pacific Biological Station, Nanaimo, British Columbia.

Toews, D. A. A., and M. K. Moore. 1982b. The effects of streamside logging on large organic debris in Carnation Creek. Pacific Region Department of Fisheries and Oceans, Land Management Report 11, Vancouver, British Columbia.

Triska, F. J., J. R Sedell, K. Cromack, Jr., S. V. Gregory, and F. M. McCorison. 1984. Nitrogen budget for a small coniferous forest stream. Ecological Monographs 54:119-140.

Tschaplinski, P. J., and G. F. Hartman. 1983. Winter distribution of juvenile coho salmon (Oncorhynchus kisutch) before and after logging in Carnation Creek, British Columbia, and some implications for overwinter survival. Canadian Journal of Fisheries and Aquatic Sciences 40:452-461.

Volk, C. J., P. M. Kiffney, and R. L. Edmonds. 2003. Role of riparian red alder (Alnus rubra) in the nutrient dynamics of coastal streams of the Olympic Peninsula, WA, USA. Pages 213-228 in American Fisheries Society Special Publication 34, Bethesda, Maryland.

Vouri, K., and I. Joensuu. 1996. Impact of forest drainage on the macroinvertebrates of a small boreal headwater stream: do buffer zones protect lotic biodiversity? Biological Conservation 77:87-95.

Warren, D. R., and C. E. Kraft. 2003. Brook trout (Salvelinus fontinalis) response to wood removal from high-gradient streams of the Adirondack Mountains (N.Y., U.S.A.). Canadian Journal of Fisheries and Aquatic Sciences 60:379-389.

Waters, T. F. 1995. Sediment in streams: sources, biological effects, and control. American Fisheries Society, Bethesda, Maryland.

Wege, G. J., and R. O. Anderson. 1978. Relative weight $\left(W_{r}\right)$ : a new index of condition for largemouth bass. Pages 79-91 in G. D. Novinger and J. G. Dillard, editors. New approaches to the management of small impoundments. American Fisheries Society, North Central Division, Special Publication 5, Bethesda, Maryland. 
West Virginia Division of Forestry. 2005. West Virginia silvicultural best management practices for controlling soil erosion and sedimentation from logging operations. WVDOF-TR-053, Charleston.

Williams, L. R., C. H. Taylor, M. L. Warren Jr., and J. A. Clingenpeel. 2002. Large-scale effects of timber harvesting on stream systems in the Ouachita Mountains, Arkansas, USA. Environmental Management 29:76-87.

Wipfli, M. S., and D. P. Gregovich. 2002. Invertebrate and detritus export from fishless headwater streams in southeast Alaska: implications for upland forest management and downstream fish-bearing habitats. Freshwater Biology 47:957-970.

Wilzbach, M. A., and K. W. Cummins. 1986. Influence of habitat manipulations on interactions between cutthroat trout and invertebrate drift. Ecology 67:898-911.

Young, M. 1995. Telemetry-determined diurnal positions of brown trout (Salmo trutta) in two south-central Wyoming streams. American Midland Naturalist 133:264-273.

Zippin, C. 1958. The removal method of population estimation. Journal of Wildlife Management 22:82-90. 
Table 1. Summary descriptive stream statistics of the eight study streams in the Middle Fork River watershed, Randolph County, West Virginia (March 2005 - December 2008).

\begin{tabular}{lcccc}
\hline Stream & $\begin{array}{c}\text { Stream } \\
\text { Order }\end{array}$ & $\begin{array}{c}\text { Mean wetted } \\
\text { width }(\mathrm{m})\end{array}$ & $\begin{array}{c}\text { Mean Gradient } \\
(\%)\end{array}$ & $\begin{array}{c}\text { Mean Elevation } \\
(\mathrm{m})\end{array}$ \\
\hline Birch Fork & 2 & 3.22 & 2.92 & 847 \\
Kittle Creek & 2 & 2.42 & 2.99 & 780 \\
Mitchell Lick & 1 & 2.01 & 3.98 & 810 \\
Mulberry Fork & 1 & 1.95 & 4.95 & 701 \\
North Panther Run & 1 & 2.57 & 3.90 & 749 \\
Rocky Run & 2 & 3.28 & 3.77 & 890 \\
Schoolcraft Run & 2 & 2.97 & 2.89 & 737 \\
South Panther Run & 1 & 2.54 & 2.66 & 804 \\
\hline
\end{tabular}


Table 2. Initial (pre-harvest) brook trout density in eight tributaries of the Middle Fork River, Randolph County, West Virginia.

\begin{tabular}{|c|c|c|c|c|c|}
\hline Sample Date & $\begin{array}{c}\text { \% Basal Area } \\
\text { Removal } \\
\text { Treatment }\end{array}$ & Stream & Section & $\begin{array}{c}\text { Age 1+ } \\
\text { Density } \\
\# / 100 \mathrm{~m}^{2} \\
\end{array}$ & $\begin{array}{c}\text { YOY } \\
\text { Density } \\
\# / 100 \mathrm{~m}^{2} \\
\end{array}$ \\
\hline \multirow[t]{24}{*}{ March 2005} & \multirow[t]{12}{*}{$50 \%$} & \multirow[t]{3}{*}{ Birch Run } & Removal & 14.525 & - \\
\hline & & & Removal + LWD & 5.390 & - \\
\hline & & & Reference & 11.010 & - \\
\hline & & \multirow[t]{3}{*}{ Kittle Creek } & Removal & 7.577 & - \\
\hline & & & Removal + LWD & 9.463 & - \\
\hline & & & Reference & 11.825 & - \\
\hline & & \multirow[t]{3}{*}{ Mulberry Fork } & Removal & 0.000 & - \\
\hline & & & Removal + LWD & 0.164 & - \\
\hline & & & Reference & 0.000 & - \\
\hline & & \multirow[t]{3}{*}{ N. Panther Run } & Removal & 10.215 & - \\
\hline & & & Removal + LWD & 4.756 & - \\
\hline & & & Reference & 13.354 & - \\
\hline & \multirow[t]{12}{*}{$90 \%$} & \multirow[t]{3}{*}{ Mitchell Lick } & Removal & 34.100 & - \\
\hline & & & Removal + LWD & 23.972 & - \\
\hline & & & Reference & 37.600 & - \\
\hline & & \multirow{3}{*}{ Rocky Run } & Removal & 4.022 & - \\
\hline & & & Removal + LWD & 11.858 & - \\
\hline & & & Reference & 10.966 & - \\
\hline & & \multirow[t]{3}{*}{ Schoolcraft Run } & Removal & 18.994 & - \\
\hline & & & Removal + LWD & 9.182 & - \\
\hline & & & Reference & 25.626 & - \\
\hline & & \multirow[t]{3}{*}{ S. Panther Run } & Removal & 5.731 & - \\
\hline & & & Removal + LWD & 5.532 & - \\
\hline & & & Reference & 3.386 & - \\
\hline \multirow{24}{*}{ June 2005} & \multirow[t]{12}{*}{$50 \%$} & \multirow[t]{3}{*}{ Birch Run } & Removal & 11.416 & 0.534 \\
\hline & & & Removal + LWD & 7.076 & 0.000 \\
\hline & & & Reference & 13.501 & 0.000 \\
\hline & & \multirow[t]{3}{*}{ Kittle Creek } & Removal & 7.020 & 0.179 \\
\hline & & & Removal + LWD & 7.196 & 0.197 \\
\hline & & & Reference & 12.135 & 0.184 \\
\hline & & \multirow[t]{3}{*}{ Mulberry Fork } & Removal & 1.214 & 0.000 \\
\hline & & & Removal + LWD & 0.655 & 0.000 \\
\hline & & & Reference & 0.396 & 0.000 \\
\hline & & \multirow[t]{3}{*}{ N. Panther Run } & Removal & 15.993 & 1.481 \\
\hline & & & Removal + LWD & 6.266 & 2.919 \\
\hline & & & Reference & 20.765 & 0.831 \\
\hline & \multirow[t]{12}{*}{$90 \%$} & \multirow[t]{3}{*}{ Mitchell Lick } & Removal & 40.171 & 0.000 \\
\hline & & & Removal + LWD & 20.529 & 0.999 \\
\hline & & & Reference & 32.591 & 0.305 \\
\hline & & \multirow{3}{*}{ Rocky Run } & Removal & 5.659 & 0.000 \\
\hline & & & Removal + LWD & 9.264 & 0.000 \\
\hline & & & Reference & 8.945 & 0.000 \\
\hline & & \multirow[t]{3}{*}{ Schoolcraft Run } & Removal & 24.920 & 1.423 \\
\hline & & & Removal + LWD & 21.482 & 2.537 \\
\hline & & & Reference & 34.046 & 1.068 \\
\hline & & \multirow[t]{3}{*}{ S. Panther Run } & Removal & 7.747 & 1.725 \\
\hline & & & Removal + LWD & 7.281 & 1.844 \\
\hline & & & Reference & 7.615 & 2.143 \\
\hline
\end{tabular}




\begin{tabular}{|c|c|c|c|c|c|}
\hline \multirow[t]{24}{*}{ August 2005} & \multirow[t]{12}{*}{$50 \%$} & \multirow[t]{3}{*}{ Birch Run } & Removal & 5.272 & 2.976 \\
\hline & & & Removal + LWD & 8.758 & 0.428 \\
\hline & & & Reference & 12.336 & 1.038 \\
\hline & & \multirow[t]{3}{*}{ Kittle Creek } & Removal & 7.785 & 2.197 \\
\hline & & & Removal + LWD & 7.999 & 2.460 \\
\hline & & & Reference & 14.534 & 3.280 \\
\hline & & \multirow[t]{3}{*}{ Mulberry Fork } & Removal & 1.943 & 0.000 \\
\hline & & & Removal + LWD & 1.146 & 0.819 \\
\hline & & & Reference & 0.396 & 0.000 \\
\hline & & \multirow[t]{3}{*}{ N. Panther Run } & Removal & 15.202 & 7.126 \\
\hline & & & Removal + LWD & 4.523 & 6.021 \\
\hline & & & Reference & 17.758 & 3.769 \\
\hline & \multirow[t]{12}{*}{$90 \%$} & \multirow[t]{3}{*}{ Mitchell Lick } & Removal & 26.573 & 7.452 \\
\hline & & & Removal + LWD & 14.272 & 8.064 \\
\hline & & & Reference & 25.100 & 1.220 \\
\hline & & \multirow[t]{3}{*}{ Rocky Run } & Removal & 4.605 & 0.126 \\
\hline & & & Removal + LWD & 4.897 & 0.515 \\
\hline & & & Reference & 6.070 & 0.734 \\
\hline & & \multirow[t]{3}{*}{ Schoolcraft Run } & Removal & 27.770 & 7.457 \\
\hline & & & Removal + LWD & 24.491 & 5.995 \\
\hline & & & Reference & 29.013 & 8.072 \\
\hline & & \multirow[t]{3}{*}{ S. Panther Run } & Removal & 2.760 & 0.873 \\
\hline & & & Removal + LWD & 5.601 & 3.321 \\
\hline & & & Reference & 9.132 & 1.429 \\
\hline \multirow[t]{24}{*}{ November 2005} & \multirow[t]{12}{*}{$50 \%$} & \multirow[t]{3}{*}{ Birch Run } & Removal & 5.271 & 0.668 \\
\hline & & & Removal + LWD & 3.184 & 1.212 \\
\hline & & & Reference & 6.261 & 2.035 \\
\hline & & \multirow[t]{3}{*}{ Kittle Creek } & Removal & 3.677 & 4.569 \\
\hline & & & Removal + LWD & 4.132 & 2.164 \\
\hline & & & Reference & 7.389 & 5.770 \\
\hline & & \multirow{3}{*}{ Mulberry Fork } & Removal & 1.700 & 0.000 \\
\hline & & & Removal + LWD & 1.965 & 0.000 \\
\hline & & & Reference & 0.396 & 0.000 \\
\hline & & \multirow[t]{3}{*}{ N. Panther Run } & Removal & 3.855 & 0.363 \\
\hline & & & Removal + LWD & 0.780 & 0.260 \\
\hline & & & Reference & 2.700 & 1.731 \\
\hline & \multirow[t]{12}{*}{$90 \%$} & \multirow[t]{3}{*}{ Mitchell Lick } & Removal & 12.696 & 10.097 \\
\hline & & & Removal + LWD & 7.192 & 4.661 \\
\hline & & & Reference & 12.269 & 9.107 \\
\hline & & \multirow[t]{3}{*}{ Rocky Run } & Removal & 2.603 & 0.251 \\
\hline & & & Removal + LWD & 3.376 & 0.457 \\
\hline & & & Reference & 4.072 & 0.294 \\
\hline & & \multirow[t]{3}{*}{ Schoolcraft Run } & Removal & 20.524 & 4.506 \\
\hline & & & Removal + LWD & 13.677 & 4.636 \\
\hline & & & Reference & 21.431 & 3.203 \\
\hline & & \multirow[t]{3}{*}{ S. Panther Run } & Removal & 6.536 & 3.105 \\
\hline & & & Removal + LWD & 7.597 & 0.845 \\
\hline & & & Reference & 2.963 & 2.557 \\
\hline
\end{tabular}


Table 3. Summary of mean (SE) movement statistics for study sections in the Middle Fork River, Randolph County, West Virginia (March 2007 - December 2008).

\begin{tabular}{lccc}
\hline & Section & Retention $(\%)$ & Immigration (\%) \\
\hline 50\% removal streams & Removal & $35.6(4.4)$ & $69.1(3.3)$ \\
& Removal + LWD & $37.8(4.9)$ & $71.3(3.4)$ \\
& Reference & $58.1(9.8)$ & $60.2(3.8)$ \\
90\% removal streams & & & \\
& Removal & $39.3(5.5)$ & $66.8(3.2)$ \\
& Removal + LWD & $34.1(4.8)$ & $70.4(3.3)$ \\
& Reference & $47.9(6.5)$ & $63.7(3.5)$ \\
\hline
\end{tabular}




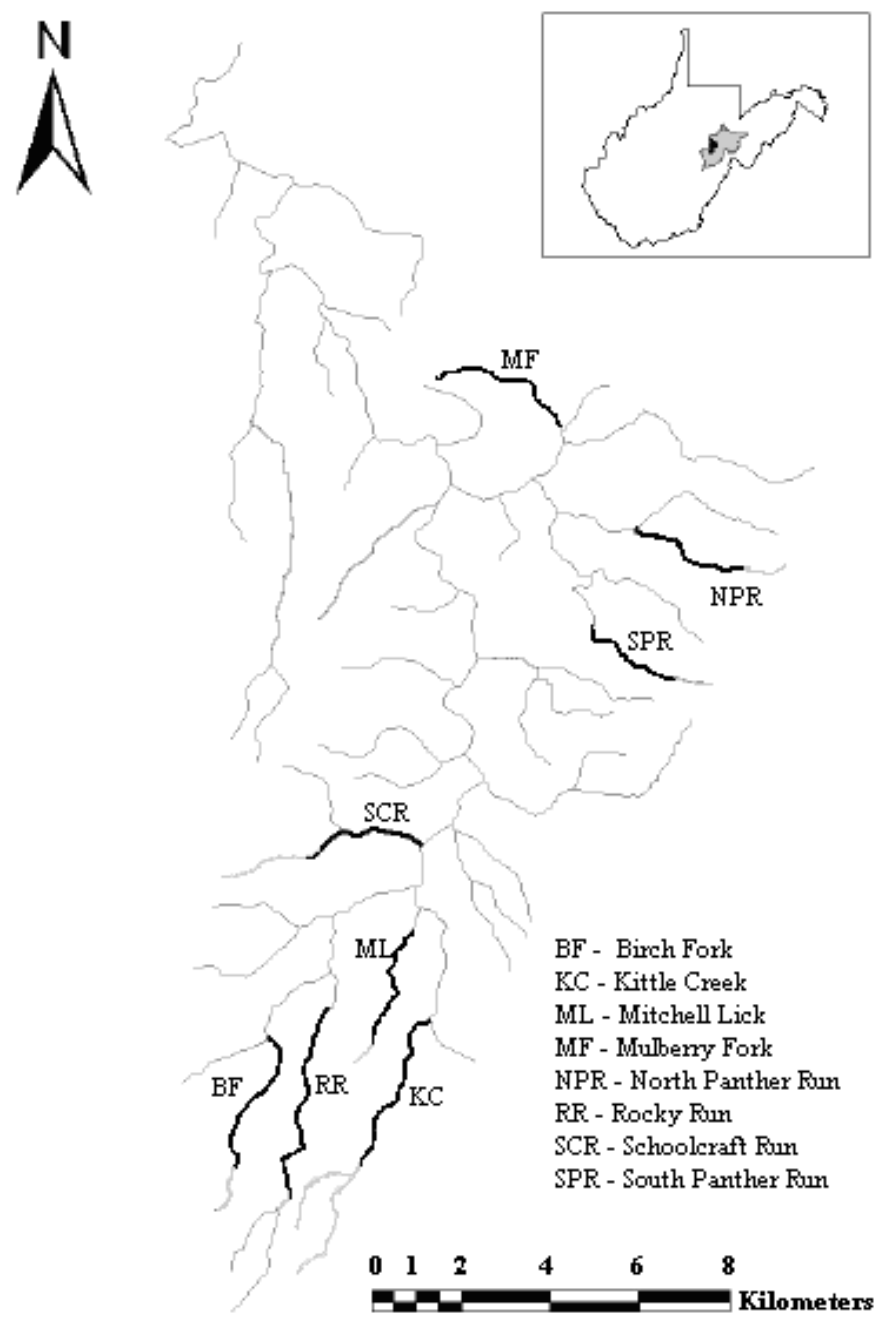

Figure 1. Middle Fork River watershed, Randolph County, West Virginia and the location of the eight study streams. 


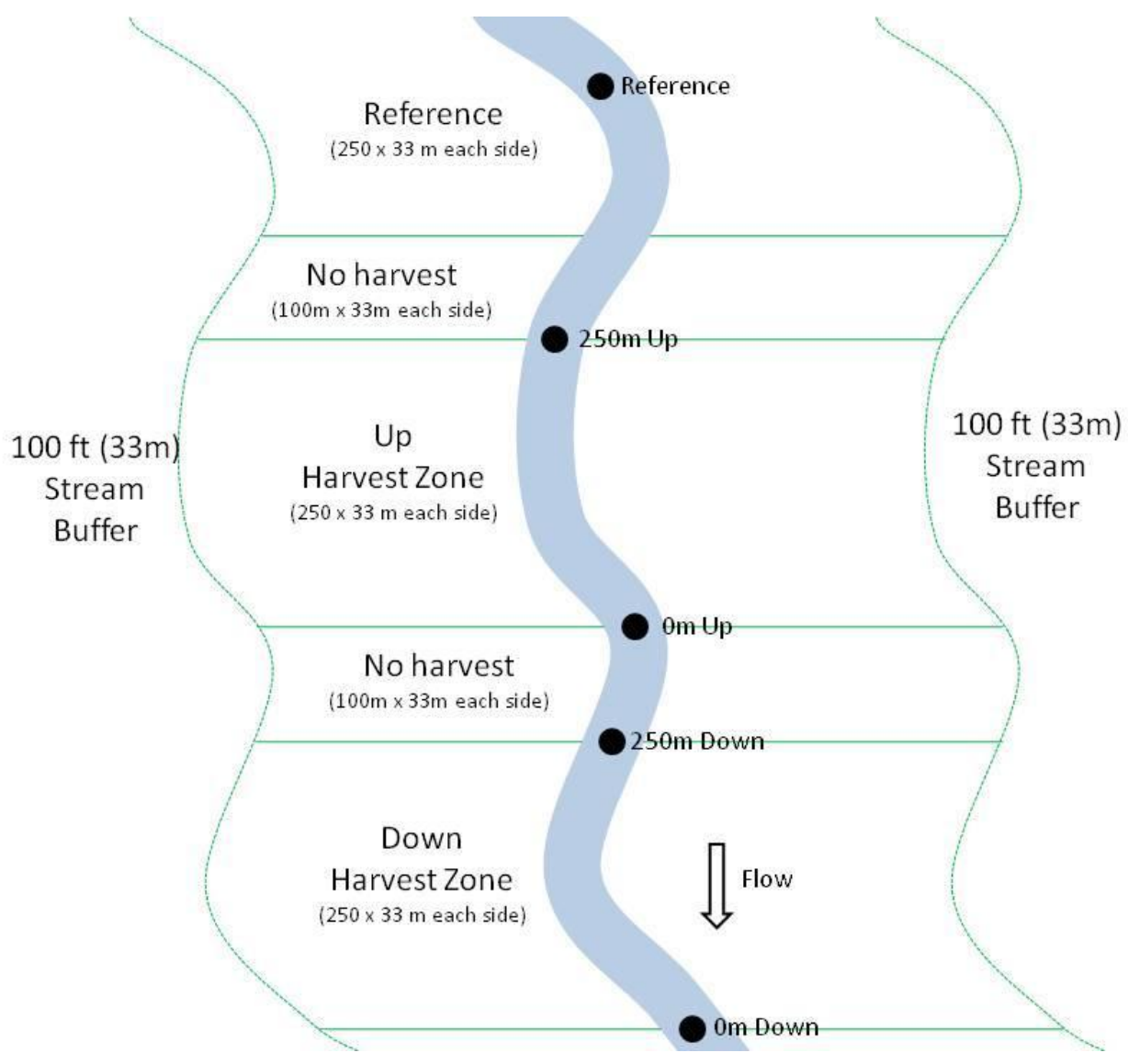

Figure 2. Schematic diagram of the study stream sections in eight tributaries of the Middle Fork River, West Virginia. The removal and removal plus Large Woody Debris (LWD) addition sections were randomly placed in either the down or up treatment locations. Arrow represents direction of stream flow. * Note exaggerated lateral scale. 


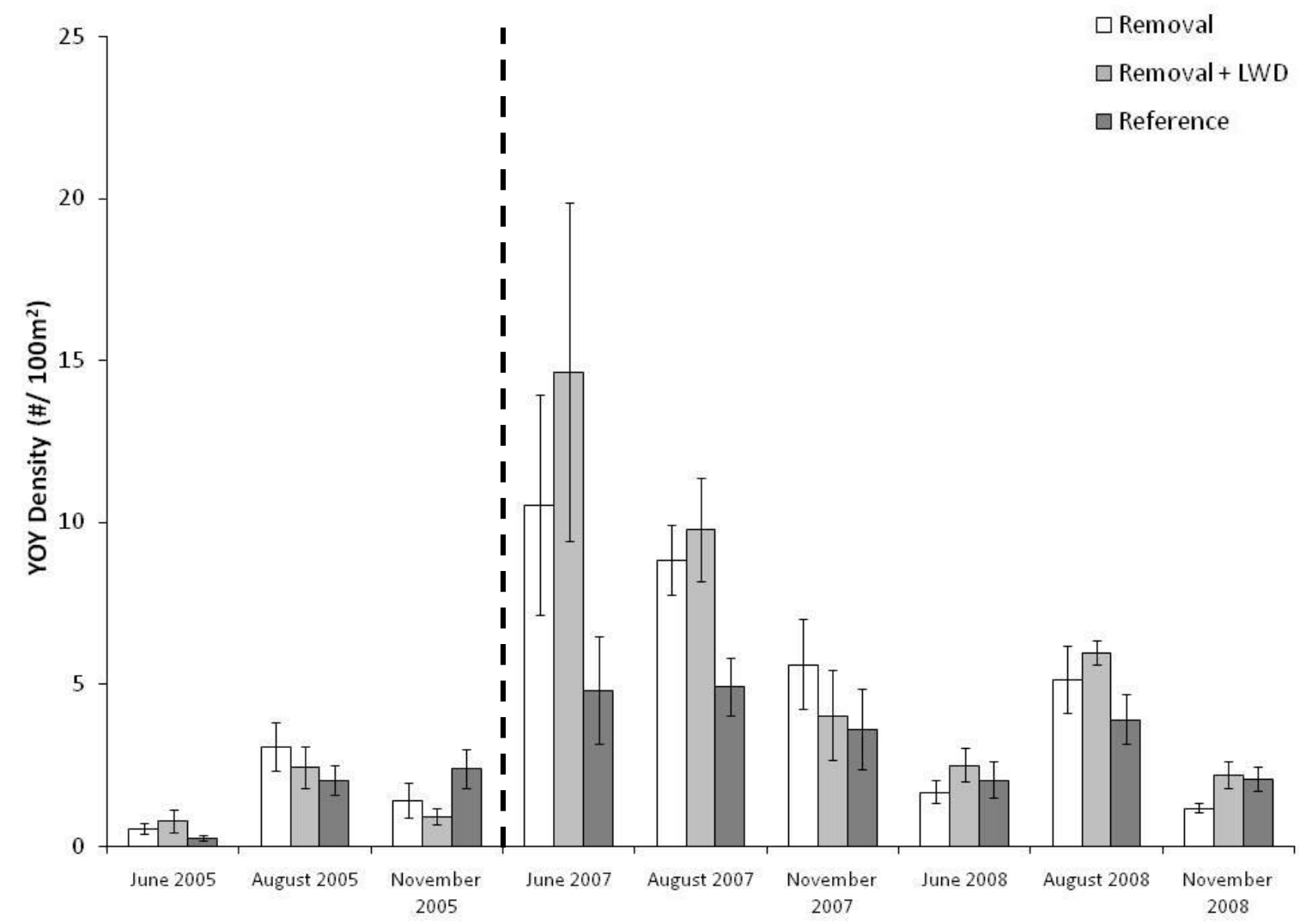

Figure 3. YOY brook trout density over time in the four $50 \%$ basal area removal streams of the Middle Fork River, West Virginia. Bars represent \pm 1 standard error. Dashed vertical line denotes pre and post treatment. 


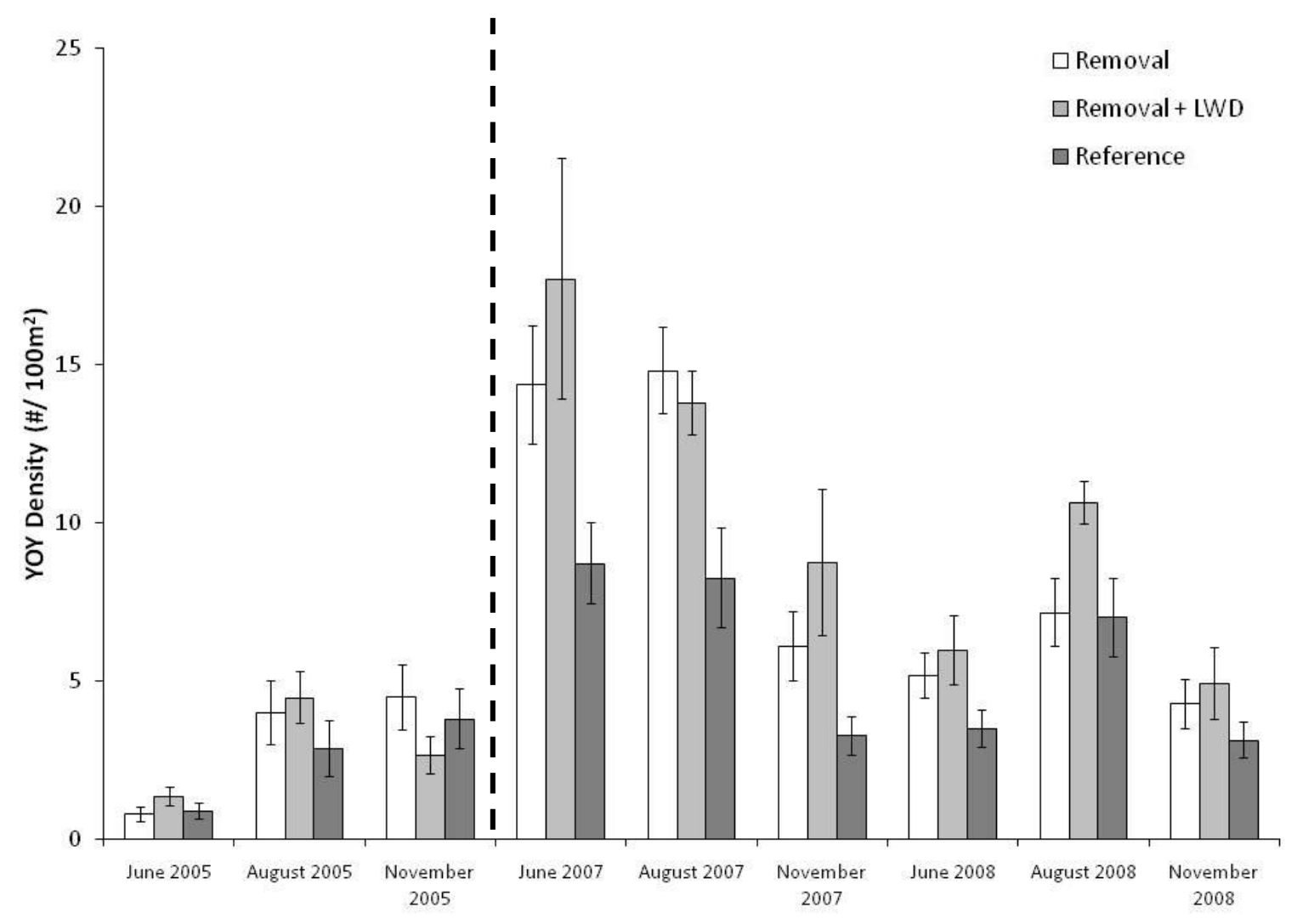

Figure 4. YOY brook trout density over time in the four $90 \%$ basal area removal streams of the Middle Fork River, West Virginia. Bars represent \pm 1 standard error. Dashed vertical line denotes pre and post treatment. 


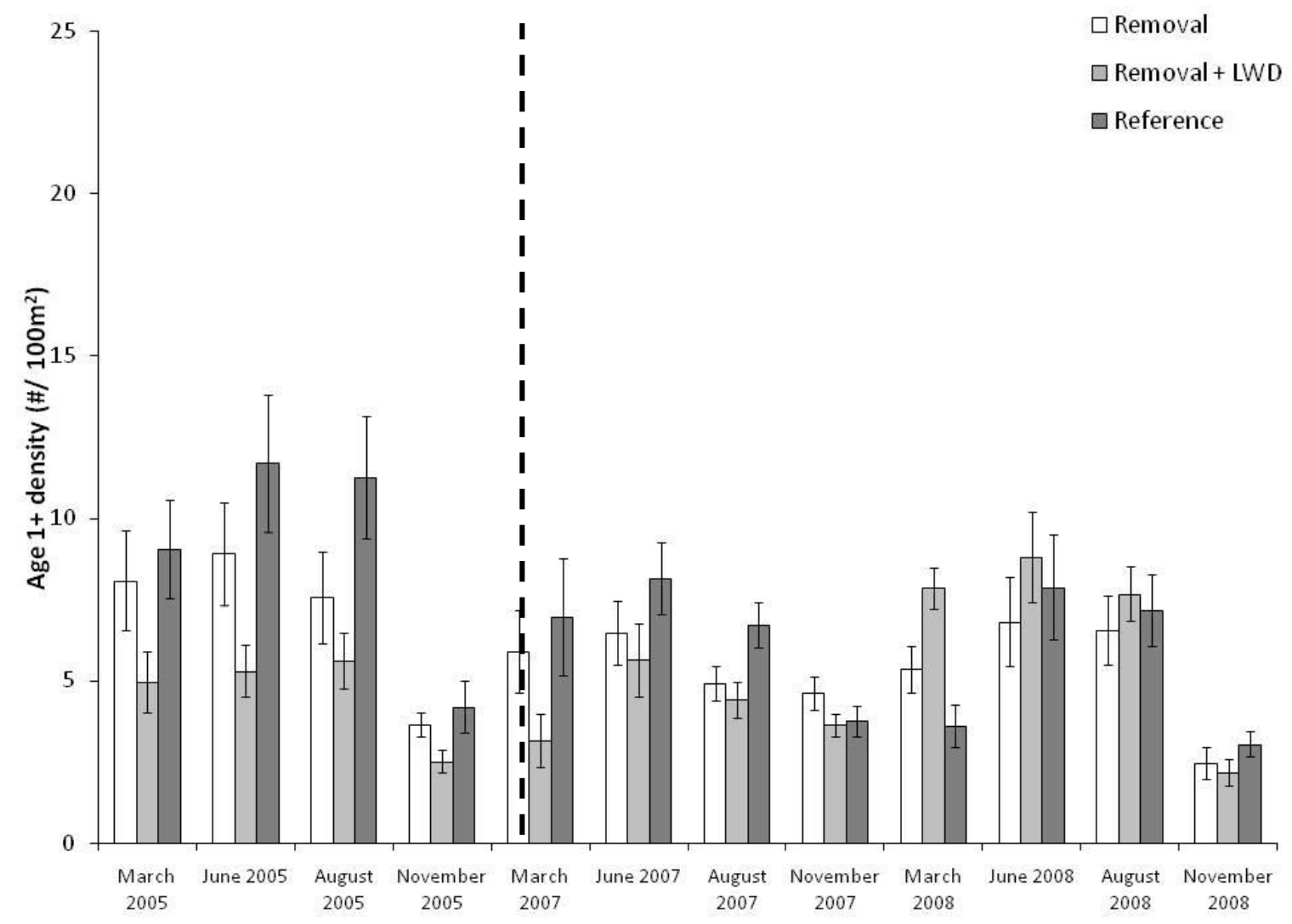

Figure 5. Age 1+ brook trout density over time in the four 50\% basal area removal streams of the Middle Fork River, West Virginia. Bars represent \pm 1 standard error. Dashed vertical line denotes pre and post treatment. 


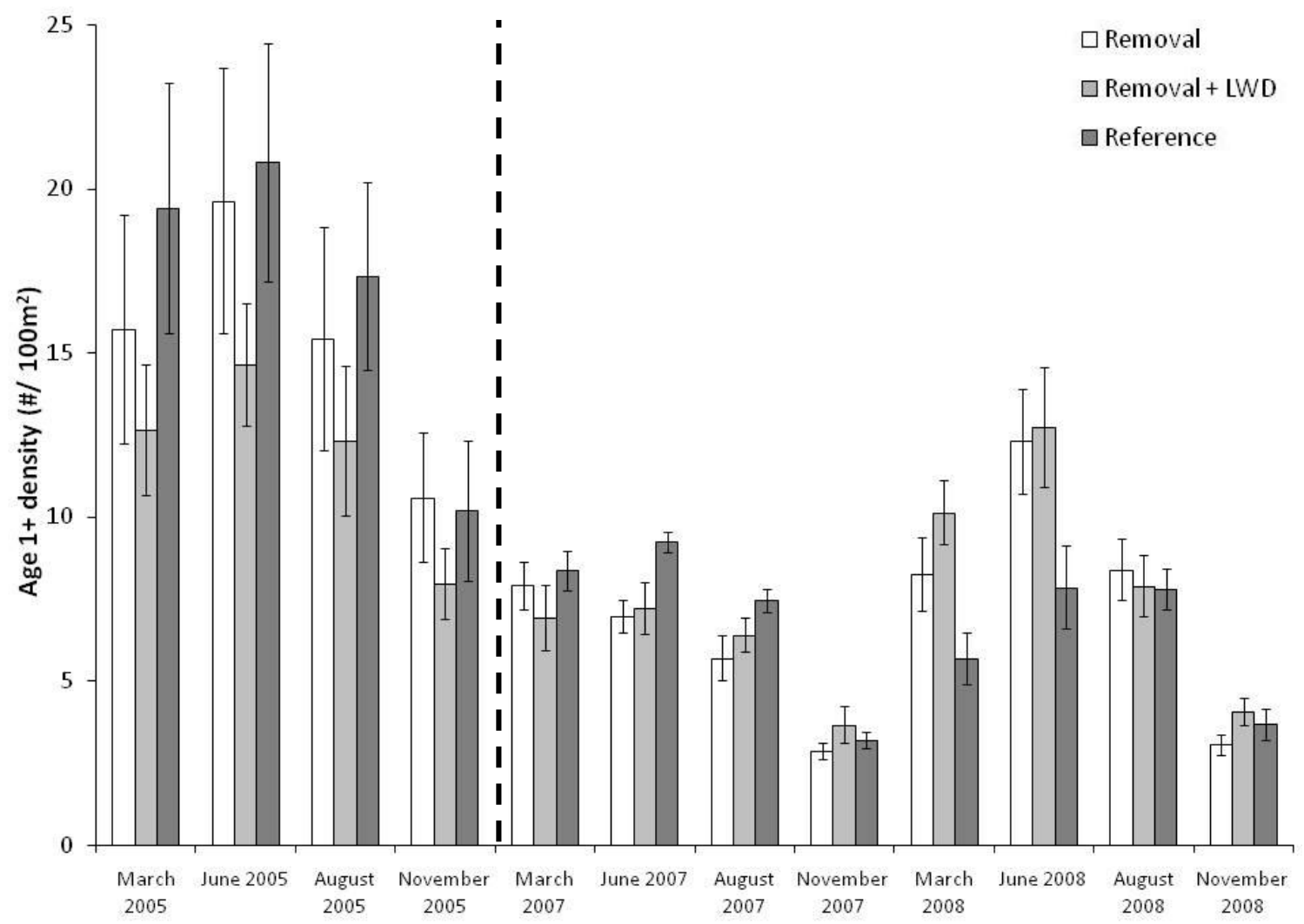

Figure 6. Age 1+ brook trout density over time in the four $90 \%$ basal area removal streams of the Middle Fork River, West Virginia. Bars represent \pm 1 standard error. Dashed vertical line denotes pre and post treatment. 


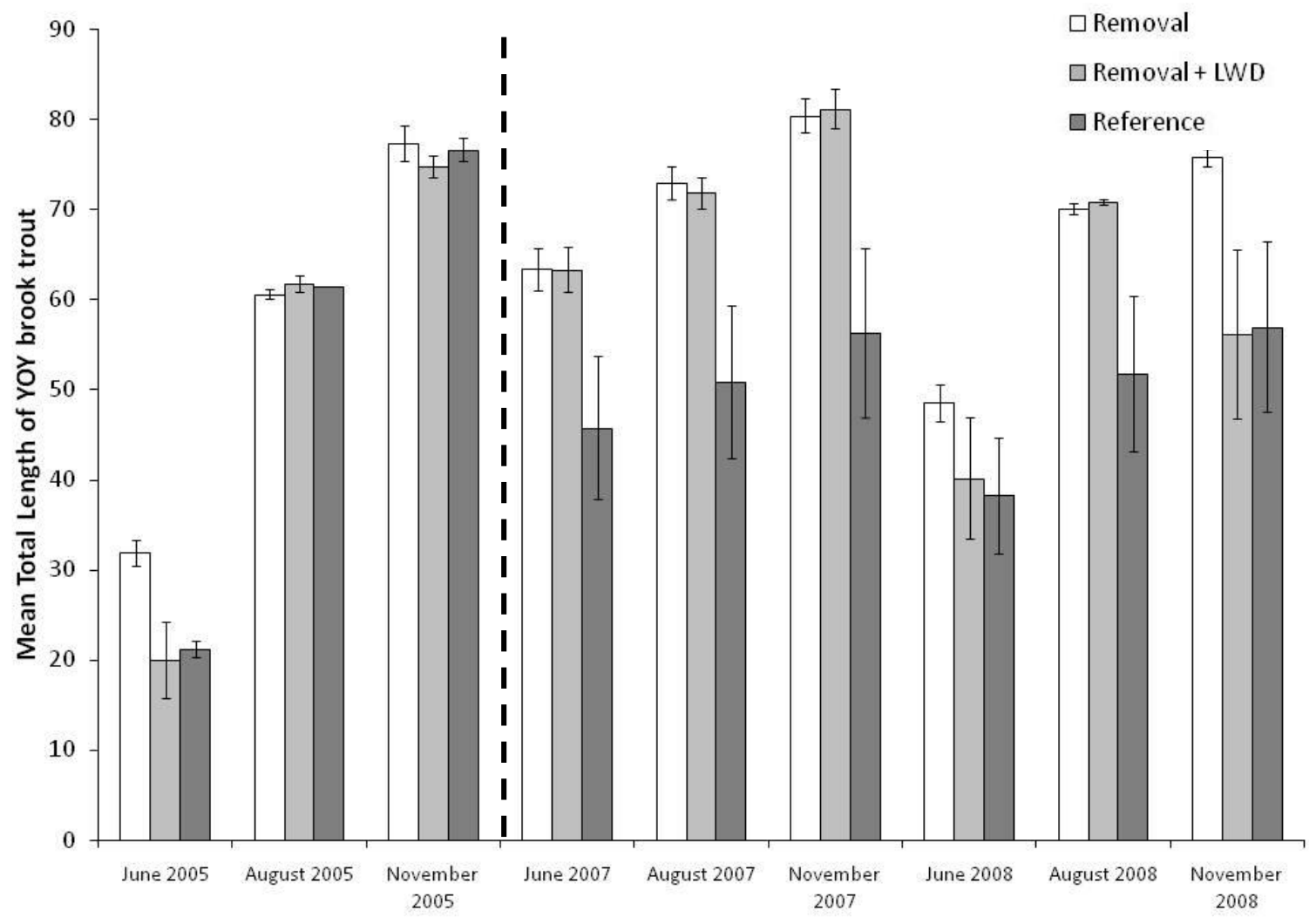

Figure 7. Mean YOY brook trout total length in four $50 \%$ basal area removal streams tributaries of the Middle Fork River, West Virginia. Bars represent \pm 1 standard error. Dashed vertical line denotes pre and post treatment. 


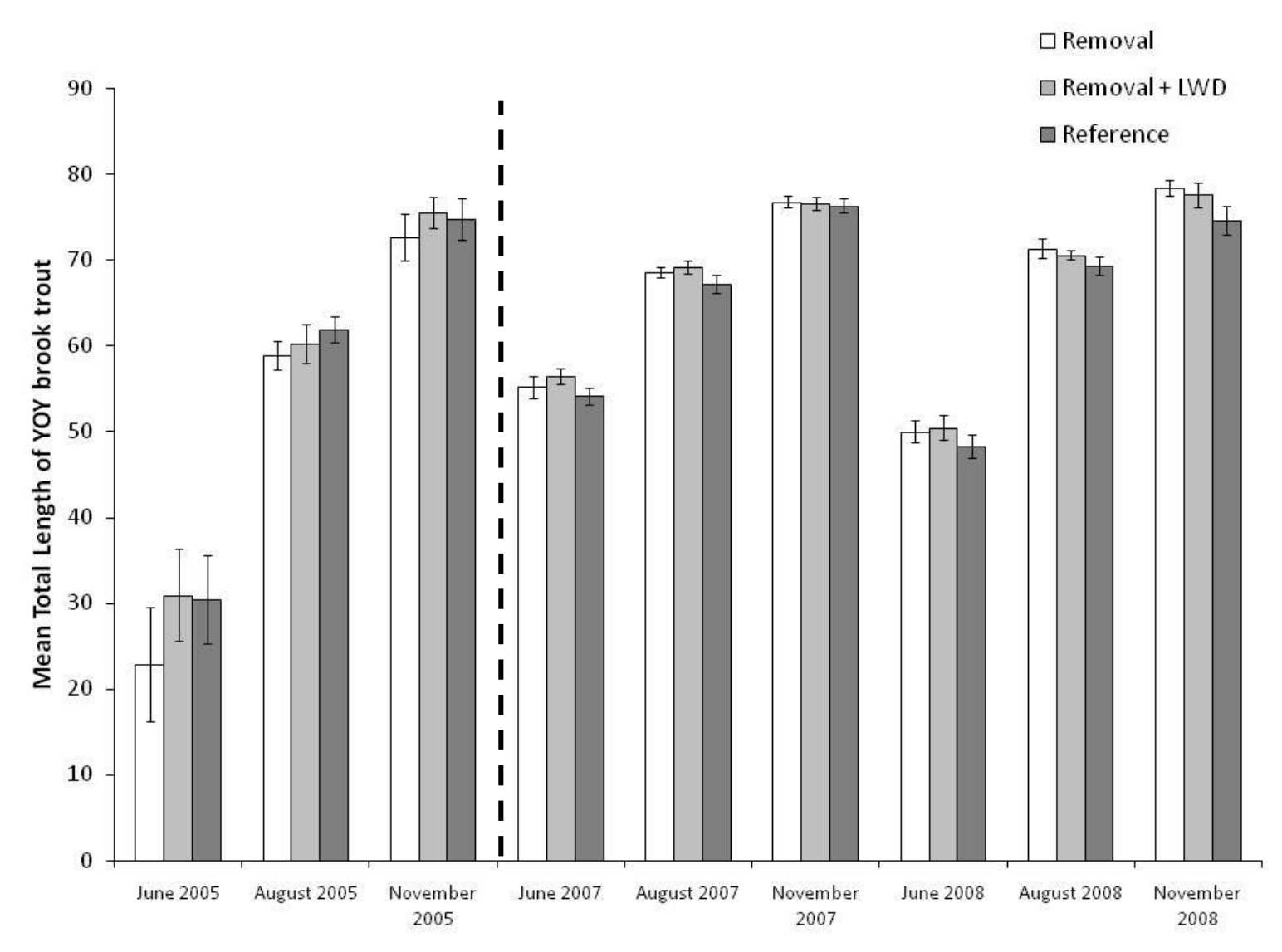

Figure 8. Mean YOY brook trout total length in four $90 \%$ basal area removal streams tributaries of the Middle Fork River, West Virginia. Bars represent \pm 1 standard error. Dashed vertical line denotes pre and post treatment. 




Figure 9. Mean age 1+ brook trout total length in four $50 \%$ basal area removal streams tributaries of the Middle Fork River, West Virginia. Bars represent \pm 1 standard error. Dashed vertical line denotes pre and post treatment. 


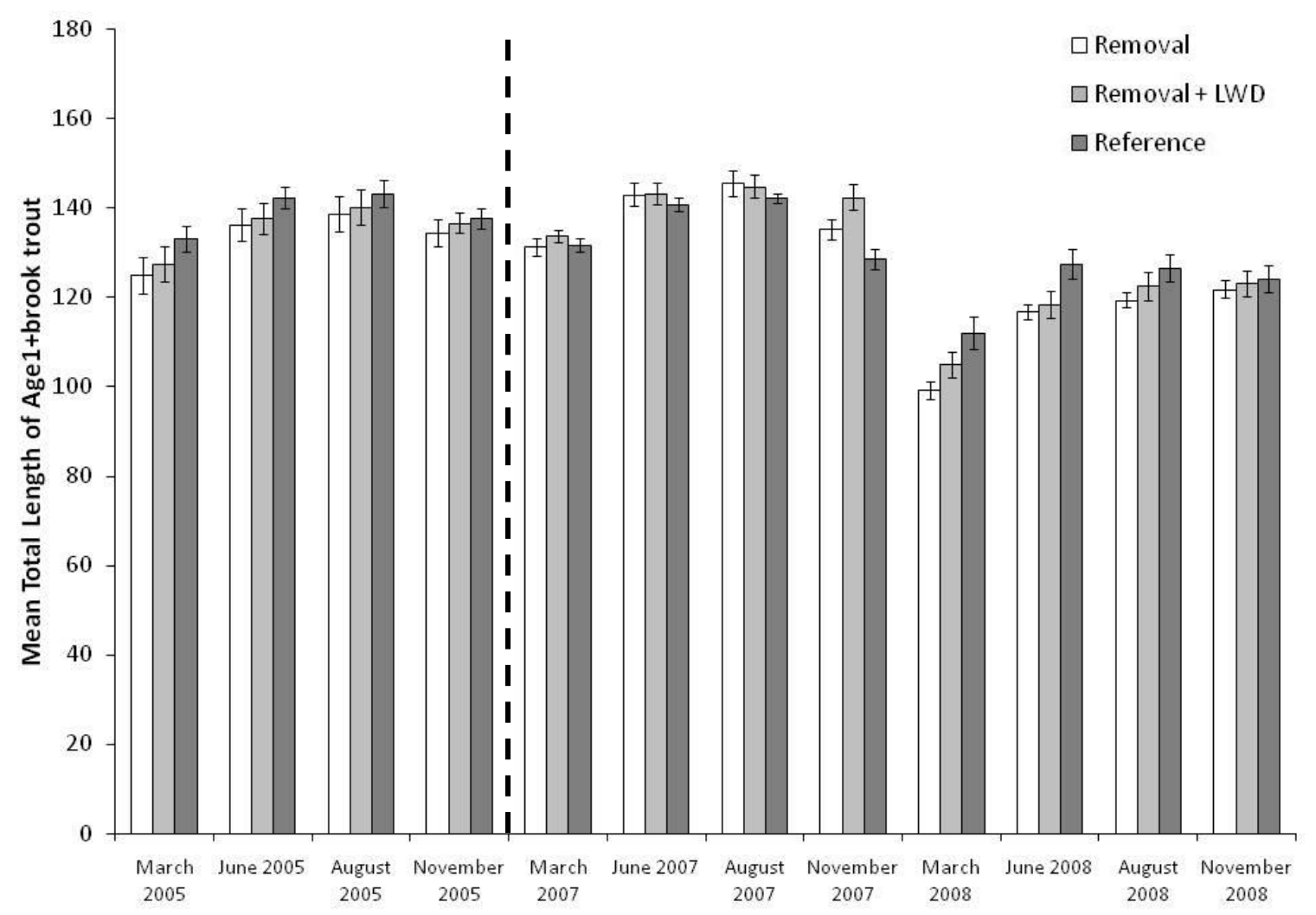

Figure 10. Mean age 1+ brook trout total length in four $90 \%$ basal area removal streams tributaries of the Middle Fork River, West Virginia. Bars represent \pm 1 standard error. Dashed vertical line denotes pre and post treatment. 


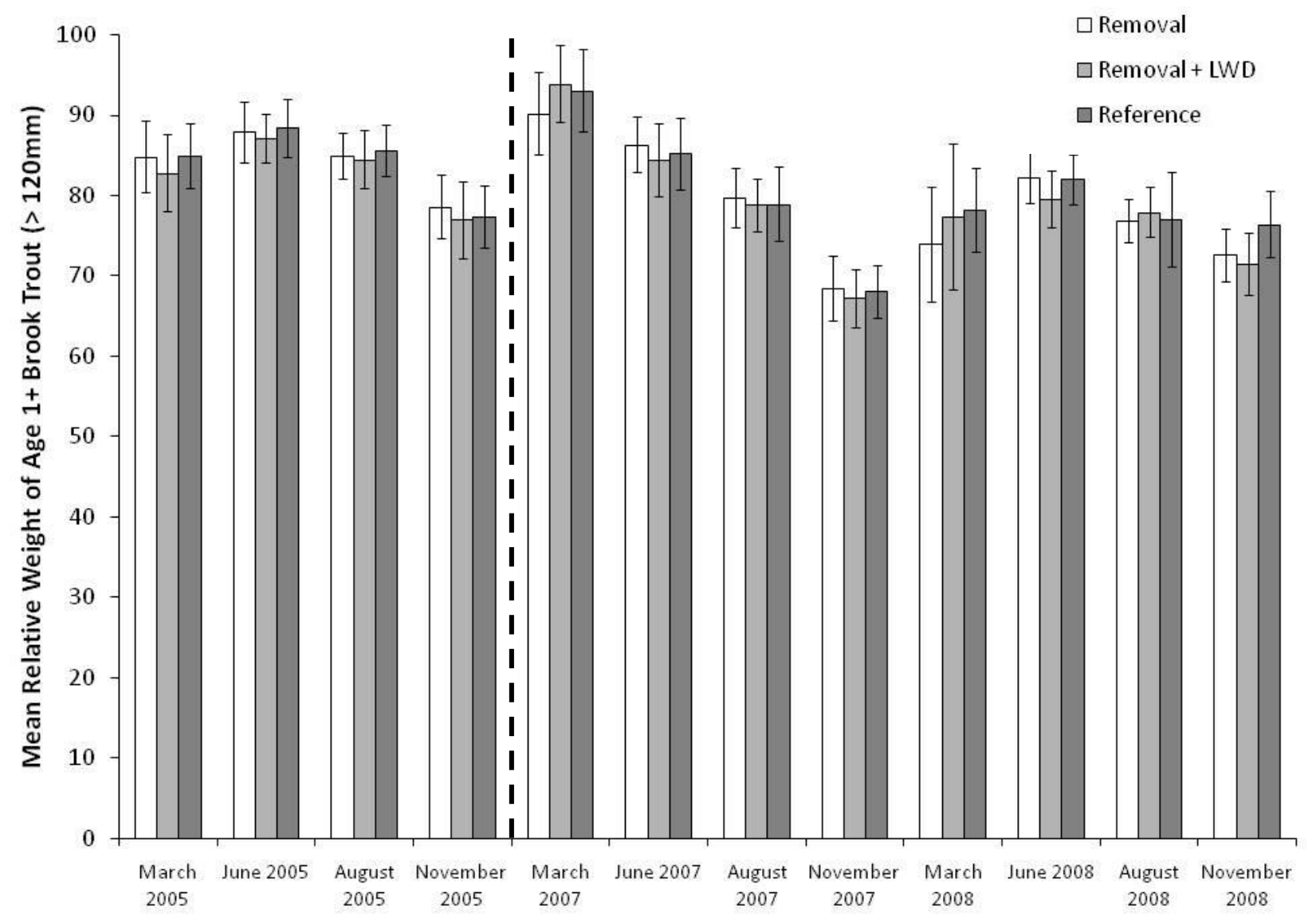

Figure 11. Mean relative weight of age $1+$ brook trout in four $50 \%$ basal area removal streams tributaries of the Middle Fork River, West Virginia. Bars represent \pm 1 standard error. Dashed vertical line denotes pre and post treatment. 


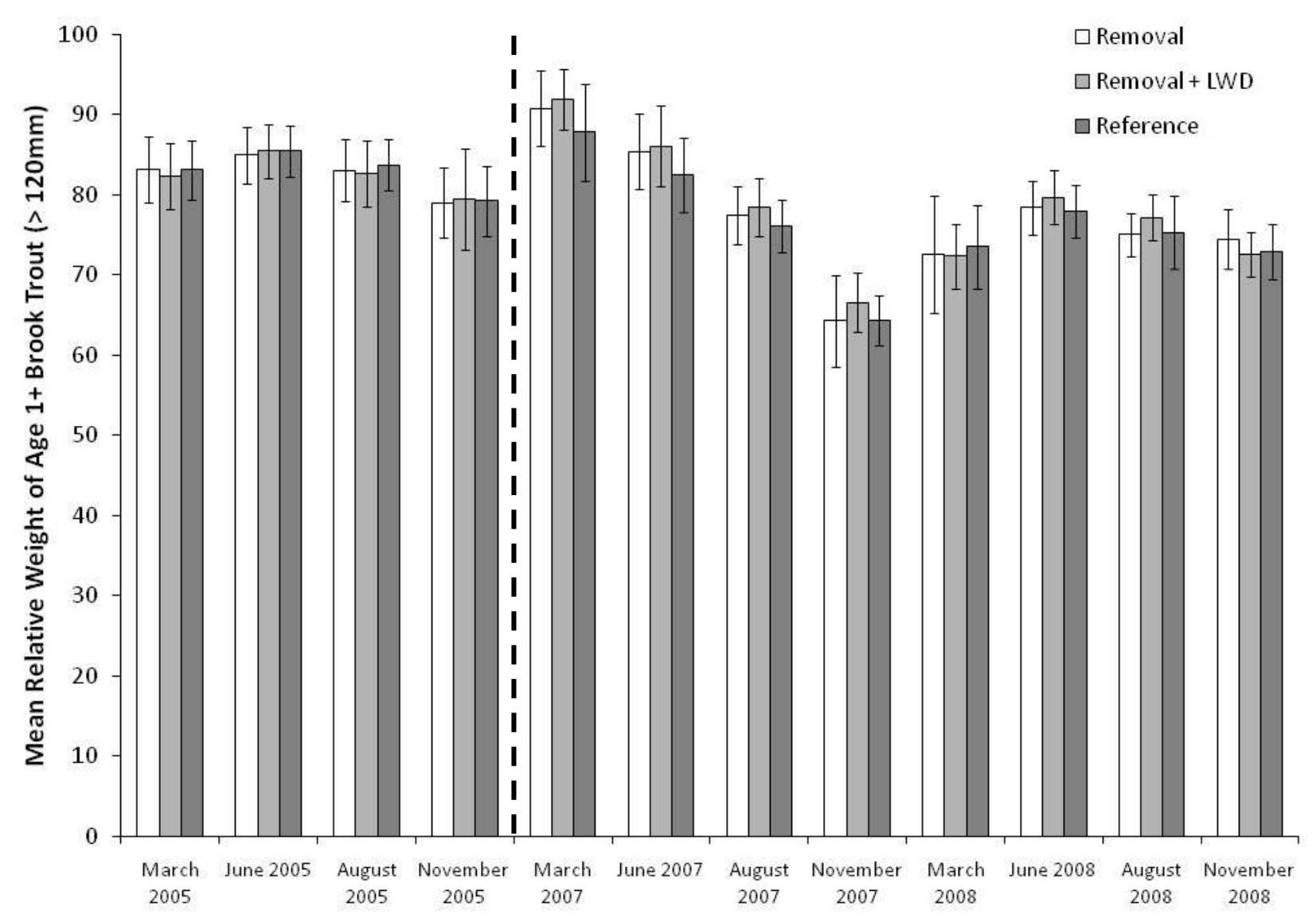

Figure 12. Mean relative weight of age 1+ brook trout in four $90 \%$ basal area removal streams tributaries of the Middle Fork River, West Virginia. Bars represent \pm 1 standard error. Dashed vertical line denotes pre and post treatment. 
Chapter 4: Effects of riparian tree removal on Appalachian brook trout diet during late summer.

\section{Abstract}

Riparian vegetation has been shown to provide prey to stream fish in the form of terrestrial invertebrates. In headwater streams terrestrial invertebrate prey can be an important energy source for brook trout (Salvelinus fontinalis), especially when aquatic prey is seasonally limited. We examined the contribution of terrestrial invertebrates to brook trout diet on four streams in central West Virginia after experimental riparian timber harvest. Consumption estimates by origin of prey varied significantly within sections over the course of the study. Brook trout consumed a greater proportion of terrestrial invertebrates in reference sections than in timber removal sections during the study. Within the $50 \%$ basal area removal streams, terrestrial invertebrates represented $64.9 \%$ of brook trout diet in reference sections and $47.0 \%$ of the diet in removal sections by number. Within $90 \%$ basal area removal streams, terrestrial invertebrates represented $52.6 \%$ of brook trout diet in reference sections and $22.6 \%$ of the diet in removal sections by number. Within the $50 \%$ removal streams, terrestrial invertebrates represented $70.4 \%$ of brook trout diet biomass (g DW) in reference sections and $39.5 \%$ of the biomass in removal sections. Within $90 \%$ removal streams, terrestrial invertebrates represented $75.6 \%$ of brook trout biomass in reference sections and $28.0 \%$ of the biomass in removal sections. Within the $50 \%$ removal streams, terrestrial invertebrates represented $70.9 \%$ of energy in the brook trout diet in reference sections and $40.5 \%$ of the energy in removal sections. Within $90 \%$ removal streams, terrestrial invertebrates represented $79.2 \%$ of brook trout energy in reference sections and $31.3 \%$ of the energy in removal sections. A MANOVA test on proportional prey by abundance showed that brook trout in removal and reference sections exploited particular prey 
taxa at significantly different rates. Throughout late summer in $90 \%$ removal sections, trout fed on a significantly higher proportion of EPT (Ephemeroptera, Plecoptera, Trichoptera), and trout in the reference sections fed on a higher proportion of terrestrial Lepidoptera. The proportion of Lepidoptera abundance, biomass and energy was significantly lower in brook trout diets in both $50 \%$ and $90 \%$ removal sections compared to reference sections. Previous research has shown that Lepidoptera play an important role in sustaining summer brook trout populations and the removal of forest canopy resulted in reductions in Lepidoptera input to the streams. Terrestrial invertebrates represent a greater proportion of the abundance, biomass and energy for brook trout in reference sites and may be greatly reduced in timbered areas. Thus, timber harvest even at the $50 \%$ basal area removal level results in disruptions in the food web in these Appalachian headwater streams.

\section{Introduction}

Riparian conditions affect stream ecosystems in a number of ways. Riparian vegetation along streams can influence light and thermal regimes (Weatherly and Ormerod 1990, Tait et al. 1994), the source of nutrients and detritus (Bilby and Bisson 1992, Vought et al 1994), and terrestrial invertebrates (Allan et al. 2003, Kawaguchi and Nakano 2001). The riparian ecosystem has long been recognized as providing the energy base for trophic dynamics in small headwater streams of deciduous forests (Vannote et al. 1980, Wallace et al. 1997). Freshwater stream communities commonly receive prey and detritus subsidies from surrounding habitats. Allochthonous inputs of leaf litter and woody debris provide the energy necessary to support higher trophic levels in low order forested streams (Vannote et al. 1980). This energy is indirectly available to fish through benthic invertebrate production (Nakano et al. 1999). 
Research has shown that benthic invertebrate production within streams is often less than that required to support fish. Allen (1951) believed benthic invertebrate production to be below levels necessary for fish production in small streams yet fish populations persist; a notion that has become known as the Allen Paradox. One explanation for the Allen Paradox is the input of energy sources directly to stream fish in the form of terrestrial invertebrates (Edwards and Huryn 1995, Wipfli 1997, Utz and Hartman 2007, Sweka and Hartman 2008).

Brook trout (Salvelinus fontinalis) of the central and southern Appalachians inhabit small headwater streams where benthic invertebrate production may be considered low (Cada et al. 1987), especially during the late summer and fall. Food availability, in terms of drift density, generally decreases from the spring to fall seasons (Allan 1981, Wipfli 1997) and overall prey consumption by brook trout may be below maintenance ration levels during the late summer months (Ensign et al. 1990, Utz and Hartman 2007). Sweka (2003) found that brook trout showed negative growth through the summer and into the fall indicating energy deficit with reduced terrestrial invertebrate consumption.

Riparian vegetation has been shown to provide prey to stream fish in the form of terrestrial invertebrates (Cadwallader et al. 1980, Wipfli 1997). Terrestrial invertebrates commonly occur in salmonid diets (Elliot 1973, Hubert and Rhodes 1989, Forrester et al. 1994), but until recently researchers have paid relatively little attention to their importance as an energy source (Kawaguchi and Nakano 2001, Utz and Hartman 2007, Sweka and Hartman 2008) and have focused more on relationships between aquatic invertebrate drift and diet composition. The contributions of terrestrial invertebrates to total ingested biomass and energy vary with respective studies, time of the year, and forest type (Allan 1981, Hubert and Rhodes 1989, Wipfli 1997). The general consensus in the literature is that the contribution of terrestrial invertebrates 
to salmonid diets increases throughout the summer months (June - September) as aquatic invertebrates in the drift decrease (Allan 1981, Wipfli 1997, Utz and Hartman 2007, Sweka and Hartman 2008). Terrestrial invertebrates may contribute greater than $50 \%$ of the consumed biomass in salmonid diets (Allan 1981, Wipfli 1997, Utz and Hartman 2007, Sweka and Hartman 2008).

The contribution of terrestrial invertebrates to salmonid diets depends on the vegetation of the surrounding riparian area. Wipfli (1997) found terrestrial invertebrates comprised a higher proportion of salmonid diets in young-growth systems compared to old-growth systems in Alaskan streams. Kawaguchi and Nakano (2001) found terrestrial invertebrates comprised 49\% and $53 \%$ of the annual total prey consumption in forested and grassland areas of a Japanese stream. Edwards and Huryn (1996) found the input of terrestrial invertebrates was greater in forested than in grassland streams. Kawaguchi and Nakano (2001) suggested that welldeveloped overhanging vegetation should enhance the input of terrestrial invertebrates with little or no flying ability (Lepidoptera larvae and Coleoptera).

Terrestrial prey has been shown to be an important energy source for salmonids, especially when aquatic prey is seasonally limited. Kawaguchi and Nakano (2001) found terrestrial invertebrates were as much as $68 \%$ of the consumed biomass during the summer. Utz and Hartman (2007) found that terrestrial organisms are more important than aquatic organisms in sustaining brook trout populations during warmer months. Sweka and Hartman (2008) found terrestrial invertebrates comprised a large proportion of the yearly consumed biomass (36-49\%) and an even larger proportion of the yearly consumed energy (50-70\%) of brook trout.

If riparian communities control terrestrial invertebrate inputs, then riparian management activities that alter the riparian plant community may change food resources within the stream. 
Large scale removal of riparian trees would likely decrease the input of terrestrial invertebrates to stream systems and food availability to stream fish. Timber harvest can quickly decrease terrestrial invertebrate abundance, but terrestrial invertebrate abundance may increase to above pre-timber harvest levels during regeneration in subsequent years (Schowalter et al. 1981). Riparian harvest has been shown to decrease leaf litter inputs (Hetrick et al. 1998, Kreutzweiser et al 2004). This decrease can exert strong bottom-up effects and lower the invertebrate productivity for a stream (Wallace et al. 1999). Interestingly, the little research investigating the effects of timber harvest on inputs of terrestrial invertebrates into streams has failed to find significant relationships despite evidence that riparian vegetation composition affects terrestrial invertebrate communities (Allan et al 2003, Musslewhite and Wipfli 2004).

Brook trout of the Appalachians inhabit streams of low productivity and severe prey limitation (Ensign et al. 1990), and are considered opportunistic foragers, consuming a wide variety of prey (Allan 1981; Forester et al. 1994, Utz and Hartman 2007, Sweka and Hartman 2008). The opportunistic foraging behavior of brook trout in a prey limited environment presents an ideal scenario to determine how riparian tree removal influences terrestrial prey availability because changes in terrestrial prey abundance would be expected to be evident in the opportunistic diet of the fish. The purpose of this study was to determine what influence the removal of overhead riparian trees had upon terrestrial prey availability and prey consumption by brook trout.

\section{Methods}

Study site description

This study was conducted in four tributaries of the Middle Fork River, Randolph 
Co., WV. The watershed is located in the Allegheny Plateau physiographic province.

The study streams were Birch Fork (BF), Mitchell Lick (ML), North Fork Panther Run (PR), and Schoolcraft Run (SR) (Figure 1). All streams were small, of low stream order, and relatively high gradient (Table 1). Stream elevations ranged from 685 to $929 \mathrm{~m}$. The percent canopy cover of these streams averaged $80-90 \%$, and stream temperatures remained adequate for brook trout for the majority of the year with temperatures rarely exceeding $20^{\circ} \mathrm{C}$. The surrounding watersheds of all streams were actively managed for fiber production by the MeadWestvaco Corporation (property was sold to Penn Virginia Corporation in fall 2007), and timber harvest activities occurred in all watersheds throughout the study. The age of the surrounding forest ranged from 65 to 80 years and was dominated by yellow birch (Betula alleghaniensis), yellow poplar (Liriodendron tulipifera), black birch (Betula lenta), and sugar maple (Acer saccharum). All riparian areas were logged in the past with the greatest logging activity occurring in the early 1900 's and sporadically since the 1930's. Timber harvest is restricted to $50 \%$ of the basal area of trees within Streamside Management Zones (SMZ). The width of the SMZs ranges from 15 to $50 \mathrm{~m}$ depending on slope with further guidelines that prohibit the operation of heavy machinery, and construction of logging roads (West Virginia Division of Forestry 2005). Stream crossings are permitted so long as the associated road enters and exits the SMZ in the shortest possible distance and a temporary culvert and sediment control devices are established. Although limited harvest is permitted in SMZs (West Virginia Division of Forestry 2005), no such activity occurred along any of the streams during the course of the study except where designated for treatment. Evidence of timber harvest activity prior to the establishment of SMZs was apparent along of all steams with the presence of abandoned logging roads and railroad grades, stream crossings, and eroded streambanks in some areas. 
All streams have had limestone sand added annually by the West Virginia Department of Natural Resources and the West Virginia Department of Environmental Protection since the mid 1990’s (WVDNR 2001). The underlying Pottsville geology has a very low buffering capacity; therefore limestone sand is added to mitigate the effects of acid precipitation and acid mine drainage in efforts to improve water quality in the mainstem of the Middle Fork River. Limestone is added by depositing a pile of sand on the streambank which is then swept into the stream under high flow events. This method of water quality enhancement has had much success in elevating stream $\mathrm{pH}$, increasing macroinvertebrate abundance, and restoring fish communities in WV streams (Clayton and Menendez 1998, Clayton et al. 1998).

Typical of Appalachian headwater streams, fish species diversity was low in all of the streams in this study. Brook trout was the dominant species. Other species found included mottled sculpin (Cottus bairdi) and blacknose dace (Rhinichthys atratulus).

\section{Experimental design}

Two-250 m study reaches (designated removal, and reference reaches) were established on four streams and these reaches were separated by $100 \mathrm{~m}$ buffers (Figure 2). Each stream was then randomly assigned the treatment of being a 50\% removal (basal area) or a $90 \%$ removal (basal area) stream (Table 1). Reference sites were always located upstream of the removal sections, as we felt that areas downstream of treatment reaches would not be "true" reference sites due to the potential impacts of sedimentation and temperature. 


\section{Riparian tree removal}

Riparian tree removal began in July 2006 by 3 separate crews of loggers. Each logging crew was instructed to harvest trees within the SMZ as they normally would any other site while abiding to West Virginia Forestry BMPs. All trees felled within the removal section were removed from the stream channel after harvesting as they would be normally removed under West Virginia Forestry BMPs guidelines (WV Division of Forestry 2005).

\section{Terrestrial invertebrate inputs}

To assess the importance of terrestrial invertebrates for brook trout diet, we measured number, biomass and taxonomic composition of terrestrial invertebrates entering streams. Invertebrates were categorized as terrestrial (terrestrially derived) if they were a product of terrestrial secondary production.

The study began on 17 July 2007 and terminated on 17 August 2007. Forty brown floating pan-traps (Van Ness company 30.5 x 40.6 x $10.1 \mathrm{~cm}$ medium plastic pan) $\left(0.124 \mathrm{~m}^{2}\right.$ surface area with $10.1 \mathrm{~cm}$ high sides) containing $\sim 2 \mathrm{~L}$ of stream water were placed within the stream bankfull width within each study section. Traps were evenly spaced and haphazardly placed along the stream. Unlike other dietary studies (Wipfli 1997), surfactant (dish soap) was not used to help preserve trap contents or retain invertebrates as the use of dish soap may artificially inflate numbers of terrestrial invertebrate inputs by retaining those that may alight from the water's surface. Traps were tethered with nylon cord to tree roots or other structures. Trap contents were collected every 3 days. Invertebrates visible to the unaided eye were removed and the remaining pan was strained thru a $105 \mu \mathrm{m}$ sieve. Invertebrates were placed into 
bottles and preserved in $80 \%$ ethanol. For more detailed analysis of this study please see Studinski 2010.

\section{Brook trout diets}

Dietary analysis of brook trout was conducted in the two reaches of the four study streams on three occasions 25 July 2007, 9 August 2007, and 17 August 2007. This time of year was selected for diet and terrestrial invertebrate analysis as researchers have shown that terrestrial invertebrate inputs are highest during this time of year (Wipfli 1997, Kawaguchi and Nakano 2001), and brook trout heavily rely on terrestrial invertebrates to supplement their diet during this time (Utz and Hartman 2007, Sweka and Hartman 2008). The entire $250 \mathrm{~m}$ stream reach of each study stream was sampled during each sample week. Block nets were placed at the upstream and downstream ends to meet the assumption of a closed population. Brook trout were captured using a pulsed DC backpack electrofishing unit and a two pass removal technique. Care was taken to ensure that all available habitats were electrofished on each pass. Brook trout from each pass were anesthetized in a $120 \mathrm{mg} \cdot \mathrm{L}-1$ solution of clove oil (Anderson et al. 1997), individually weighed to the nearest $0.5 \mathrm{~g}$, measured to the nearest $\mathrm{mm}$ total length, and released back into the area of capture following completion of the second electrofishing pass and diet sampling procedures. Subsets of 20 brook trout per reach per sample date were randomly chosen for stomach content removal. Attempts were made to collect an equal range of fish sizes to analyze for gut content at each site, however only fish >120 mm total length were considered eligible for gut content removal due to gear restrictions ( $7 \mathrm{~mm}$ tube diameter). During the study some reaches had less than 20 brook trout greater than $120 \mathrm{~mm}$ (Table 2). Stomach contents were removed via gastric lavage, where we directed a constant flow of stream water into the 
foregut until all items had been apparently collected (Twomey and Giller 1990). Gut items were filtered into a $250 \mu \mathrm{m}$ sieve and transferred to $95 \%$ ethanol. This process of collecting stomach contents has proven effective (Light et al. 1983) and analysis with the gear used in this study has found that the technique is acceptably efficient in removing all stomach contents in brook trout (Sweka 2003, Utz 2005).

\section{Laboratory procedures}

All samples were returned to the laboratory for sorting, identification, and measurements. Stomach content and terrestrial input samples were sorted and enumerated under a dissecting microscope. All prey items were identified to the lowest taxonomic classification possible, usually Family (Merrit and Cummins 1996). Extremely small $(<0.5 \mathrm{~mm})$ organisms or organisms partially destroyed beyond identification to Family were classified to Order. The lengths of prey items were measured via an ocular micrometer to the nearest $0.1 \mathrm{~mm}$; when lengths were unavailable head capsules widths were measured to the nearest $0.1 \mathrm{~mm}$. Crayfish (Cambarus carinirostris) carapace lengths were measured rather than head capsule width or body length. The dry weight (DW) of each organism was estimated using published length- or head width-dry mass equations, with the exception of crayfish where a carapace-dry mass equation was used (Sample et al. 1993, Benke et al 1999, Johnston and Cunjak 1999, Sabo et al. 2002). Vertebrate food items, such as frogs, salamanders, and fish were dried at a temperature of $60^{\circ} \mathrm{C}$ for $48 \mathrm{hr}$ to calculate dry weight. 


\section{Consumption and energy estimates}

Prey types were grouped according to origin (terrestrial or aquatic), life stage (adult, pupae, or larvae), order and family. Each prey item was converted to units of energy (calories $\mathrm{g}^{-}$

${ }^{1}$ DW) using published dry weight energy equations (Table 3, Cummins and Wuycheck 1971), and the total energy in the gut was summarized for each fish.

Calculations were made to approximate brook trout observed consumption in terms of total energy and total biomass. The total energy intake was divided by fish weight ( $\mathrm{g}$ ) to calculate an observed consumption value (calories $\mathrm{g}^{-1}$ fish) for each fish. The total biomass (DW) consumed was divided by fish weight $(\mathrm{g})$ to calculate an observed biomass consumption value $(\mathrm{g}$ $\mathrm{DW} \mathrm{g}^{-1}$ fish) for each fish.

\section{Statistical analysis}

We utilized four methods in order to determine the overall feeding strategy of brook trout during the study; energy and biomass consumption estimates, proportional estimates by abundance, biomass, and energy of terrestrial invertebrates consumed by brook trout, total proportional prey exploitation (abundance, biomass, and energy) by brook trout, and correlation between pan traps and brook trout diet.

Consumption estimates for total energy and total biomass by origin (aquatic or terrestrial) were calculated in order to determine if fish were deriving a majority of energy from either source. Mean consumption values were calculated for both prey categories. A t-test was run on the mean aquatic and terrestrial energy and biomass consumption between sections for each sample week to determine if one category was significantly higher than the other in each section. 
Proportional diet composition by abundance, mass, and total energy was calculated for each prey type for each stream section over the entire study. The proportion of terrestrial invertebrates by abundance, mass, and total energy was compared between removal and reference sections within removal treatments using t-tests.

The 10 most common prey orders by number (aquatic and terrestrial) were selected for analysis of proportional diet composition, all other orders not in these 10 prey orders were grouped into an "other" category (other aquatic and other terrestrial). We grouped aquatic Ephemeroptera, Plecoptera, and Trichoptera together into one group (EPT) for the purpose of analysis, as the emphasis of the analysis was placed on terrestrial organisms, and having these families separate would have created a less robust analysis of potentially important terrestrial organisms. The proportional abundance, mass and energy derived from the twelve prey categories were calculated for all fish within a sample week. The proportional abundance, mass and energy derived from the twelve prey categories were square-root and then arcsine transformed to approximate normality. A multivariate analysis of variance (MANOVA) was performed in $\mathrm{R}$ on the transformed proportions to test for differences in proportional prey exploitation between sections. If an overall significant difference existed, differences in exploitation rates of specific prey were tested. The differences were considered significant at $\alpha=$ 0.05. These tests did not undergo Bonferroni correction like previous researchers (Utz 2005) as our hypothesis was that there was no difference between reference and removal sections, and the MANOVA was not exploratory.

Spearman's rank correlation coefficient was used to determine the correlation between the abundance and biomass of terrestrial invertebrate taxa in the pan traps and in the diet of 
brook trout. This analysis was done separately for each treatment. All spearman's rank correlation calculations were done using $\mathrm{R}$.

\section{Results}

Effects of riparian tree removal on invertebrates in brook trout diets

Consumption estimates by origin of prey varied significantly within sections over the course of the study. Overall energy consumption decreased throughout the course of the study. Aquatic prey energy consumption was highest in the $50 \%$ and $90 \%$ removal streams on 25 July at 18.3 and 8.7 (calories $\mathrm{g}^{-1}$ fish) respectively. Terrestrial prey consumption was highest in the

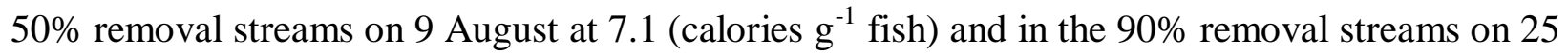
July at 5.6 (calories $\mathrm{g}^{-1}$ fish).

In the $50 \%$ removal streams, aquatic prey energy consumption in the removal sections exceeded consumption in the reference sections on 25 July $(p=0.015)$ and 9 August $(p=0.043)$ (Figure 3). Terrestrial prey energy consumption was not significantly different between removal and reference sections in these streams. Aquatic prey energy consumption in the removal sections significantly exceeded terrestrial prey energy consumption in the $50 \%$ removal streams on 25 July ( $\mathrm{p}=0.044)$, but was not significantly different on any other date (Figure 3 ). Aquatic prey consumption was not different than terrestrial prey consumption in the reference sections of the $50 \%$ removal streams.

In the $90 \%$ removal streams, aquatic prey energy consumption was significantly higher in the removal sections on 9 August $(\mathrm{p}=0.022)$. Terrestrial prey energy consumption was significantly higher in the reference sections on both 9 August $(\mathrm{p}=0.049)$ and 17 August $(\mathrm{p}=$ 0.009) (Figure 4). Aquatic prey energy consumption in the removal section significantly 
exceeded terrestrial prey energy consumption in the $90 \%$ removal streams on 9 August $(\mathrm{p}=$ 0.043) but was not significantly different on any other date (Figure 4). Aquatic prey consumption was not different than terrestrial prey consumption in the reference sections of the $90 \%$ removal streams.

Biomass consumption decreased throughout the course of the study. Aquatic prey biomass consumption was highest in the $50 \%$ and $90 \%$ removal streams on 25 July at 3.8 and 1.8 ( $\mathrm{g} \mathrm{DW}^{-1}$ fish) respectively. Terrestrial prey biomass consumption was highest in the $50 \%$ removal streams on 9 August at $1.4\left(\mathrm{~g} \mathrm{DW} \mathrm{g}^{-1}\right.$ fish) and in the $90 \%$ removal streams on 25 July at $1.1\left(\mathrm{~g} \mathrm{DW} \mathrm{g}^{-1}\right.$ fish).

In the $50 \%$ removal streams, aquatic prey biomass consumption in the removal sections exceeded biomass in the reference sections on 25 July $(p=0.013)$ and 9 August $(p=0.043)$ sample (Figure 5). Terrestrial prey biomass consumption was not significantly different between removal and reference sections in these streams. Aquatic prey biomass consumption significantly exceeded terrestrial prey biomass consumption $(p=0.034)$ in the $50 \%$ removal streams on 25 July, but was not significantly different on any other date (Figure 5).

In the $90 \%$ removal streams, aquatic prey biomass consumption in the removal sections exceeded biomass in the reference sections on 9 August $(\mathrm{p}=0.019)$, terrestrial prey biomass in the reference sections was significantly higher than biomass in the removal sections on 17 August $(\mathrm{p}=0.009)$ (Figure 6). Aquatic prey biomass consumption was not significantly different than terrestrial prey biomass consumption in the $90 \%$ removal streams on any date (Figure 6).

Removal of riparian trees had an effect on the diet of brook trout during late summer. Brook trout consumed a greater proportion of terrestrial invertebrates in reference sections than 
in removal sections during the study. Within the 50\% removal streams, terrestrial invertebrates represented $64.9 \%$ of brook trout diet in reference sections and $47.0 \%$ of the diet in removal sections (Figure 7). Paired t-tests on the total abundance of terrestrial invertebrates revealed that treatment effect was significant $(\mathrm{p}=0.045)$ in $50 \%$ removal streams. Within $90 \%$ removal streams, terrestrial invertebrates represented $52.6 \%$ of brook trout diet in reference sections and $22.6 \%$ of the diet in removal sections (Figure 7). Paired t-tests on the total abundance of terrestrial invertebrates revealed that treatment effect was also significant $(p=0.021)$ in $90 \%$ removal streams.

Proportional biomass of terrestrial invertebrates consumed by brook trout was less in removal sections than in reference sections. Within the 50\% removal streams, terrestrial invertebrates represented $70.4 \%$ of brook trout diet biomass (g DW) in reference sections and $39.5 \%$ of the diet in removal sections (Figure 8). Paired t-tests on the total biomass (g DW) of terrestrial invertebrates revealed that treatment effect was significant $(p=0.040)$ in $50 \%$ removal streams. Within $90 \%$ removal streams, terrestrial invertebrates represented $75.6 \%$ of brook trout diet in reference sections and $28.0 \%$ of the diet in removal sections (Figure 8). Paired t-tests on the total biomass of terrestrial invertebrates revealed that treatment effect was also significant ( $p$ $=0.003)$ in $90 \%$ removal streams.

Proportional energy of terrestrial invertebrates consumed by brook trout was also less in removal sections than in reference sections. Within the 50\% removal streams, terrestrial invertebrates represented $70.9 \%$ of energy in the brook trout diet in reference sections and $40.5 \%$ of the diet in removal sections (Figure 9). Paired t-tests on the total energetic value of terrestrial invertebrates revealed that treatment effect was significant $(p=0.041)$ in $50 \%$ removal streams. Within $90 \%$ removal streams, terrestrial invertebrates represented $79.2 \%$ of brook trout energy in 
reference sections and $31.3 \%$ of the diet in removal sections (Figure 9). Paired t-tests on the total energy of terrestrial invertebrates revealed that treatment effect was significant $(p=0.002)$ in $90 \%$ removal streams.

\section{Proportional prey exploitation}

The results of a MANOVA test on proportional prey by abundance showed that brook trout in removal and reference sections exploited particular prey taxa at significantly different rates (Table 4). During our study brook trout within the $50 \%$ removal and references sections had no differences in their exploitation rates of prey taxa (Table 4). Throughout late summer in 90\% removal sections, trout fed on a significantly higher proportion of EPT (Ephemeroptera, Plecoptera, Trichoptera), and trout in the reference sections fed on a higher proportion of terrestrial Lepidoptera (Table 4).

The MANOVA tests on proportional prey by biomass also showed that brook trout in removal and reference sections exploited particular prey taxa at significantly different rates (Table 5). Brook trout within the 50\% removal sections fed on a significantly higher proportion of crayfish, while brook trout in the $50 \%$ reference section fed on a higher proportion of Lepidoptera (Table 5). Within 90\% removal sections, trout fed on a significantly higher proportion of crayfish, and aquatic Diptera, while trout in the reference sections fed on a higher proportion of terrestrial Lepidoptera (Table 5).

The results of the MANOVA test on proportional prey by energy again found that brook trout in removal and reference sections exploited particular prey taxa at significantly different rates (Table 6). Brook trout within the $50 \%$ removal sections obtained energy from a significantly higher proportion of crayfish, while brook trout in the $50 \%$ reference section 
obtained energy from in higher proportions of Lepidoptera (Table 6). Brook trout in 90\% removal sections, fed on a significantly higher proportion of aquatic Diptera and EPT. Brook trout within the $90 \%$ reference sections fed on a higher proportion of terrestrial Lepidoptera (Table 6).

\section{Terrestrial prey consumption vs. availability}

Terrestrial invertebrate input from pan traps was a good predictor of the terrestrial portion of the brook trout diet. Spearman's rank correlation was used to compare percent composition data from the pan traps to the diet for each section. Terrestrial invertebrate composition data from both brook trout diets and pan traps was pooled together over the three week sampling period for both $50 \%$ and $90 \%$ removal and reference sections. In all sections of the $50 \%$ and $90 \%$ removal streams there was significant positive correlation between $\%$ composition in the diet and pans in terms of abundance (Table 7). In terms of biomass, all stream sections also showed a positive correlation between composition in pan traps and in the diet (Table 7).

\section{Discussion}

\section{Effects of riparian tree removal on terrestrial invertebrates in brook trout diets}

Terrestrial invertebrates are an important trophic link between riparian habitat and stream food webs. Terrestrial invertebrates have been shown to commonly occur in salmonid diets (Elliot 1973, Hubert and Rhodes 1989, Forrester et al. 1994), however until recently very few researchers have looked at the role of terrestrial invertebrates in salmonid bioenergetics (Utz and Hartman 2007, Sweka and Hartman 2008). In the relatively small streams of the central Appalachian Mountains, brook trout depend on terrestrial invertebrates for over half of their 
energy supply during the late summer. We found that terrestrial invertebrate contribution to brook trout diet was substantial and made an important contribution to the energy requirements of this salmonid species.

Terrestrial invertebrates composed one-half of prey ingested by brook trout in reference streams during this study and one-third of the prey in removal sections. Terrestrial invertebrates composed nearly $75 \%$ of the biomass consumed in reference sections and around $35 \%$ of the biomass consumed in removal sections. Approximately $73 \%$ of the energy brook trout gained was derived from terrestrial invertebrate in the reference sections while derived $24 \%$ of their energy was from terrestrial invertebrates in the removal sections. These numbers are similar to previous diet studies. In studies from West Virginia, Utz and Hartman (2007) found that terrestrial invertebrates prey composed two-thirds of the energy consumed by brook trout in late summer (August). Webster and Hartman (2005) found that during July terrestrial invertebrates made up $45 \%$ of the number of prey items in brook trout diets, but almost $54 \%$ of the biomass. They also found that in September that terrestrial invertebrates represented nearly $75 \%$ of the biomass found in brook trout diets. While these numbers are similar to our results these studies did not involve riparian tree removal and are only applicable for comparison of our reference areas. After adding large woody debris to streams, Sweka and Hartman (2008) found that terrestrial invertebrates prey composed $38 \%$ of the prey found in the diet of brook trout in summer, and $62 \%$ of the total biomass consumed. A series of studies from southeastern Alaska compared terrestrial invertebrate inputs between old growth and youth growth forests (30-40 years old). Allen et al. (2003) found that terrestrial invertebrates made up over one-third of the diet of coho salmon. Wipfli (1997) also studying in Alaska, found that terrestrial invertebrates made up about half of the diet of three species of juvenile salmonids. A study of terrestrial 
invertebrates in the drift in New Zealand streams found an even greater difference in invertebrate biomass, of the order of five to ten-fold, between forested and tussock grassland streams versus pasture streams (Edwards and Huryn 1996), suggesting the importance of land-use activities. In comparing grassland and forested streams in Japan, terrestrial invertebrates composed 77 and $68 \%$, respectively, during summer (Kawaguchi and Nakano 2001). In our study, terrestrial invertebrates appear to represent a greater proportion of the abundance, biomass and energy for brook trout in reference sites and may be greatly reduced in timbered areas. It is likely that terrestrial invertebrate subsidies are an important part of the solution to the "Allen paradox", which stems from Allen's (1951) finding that the production of aquatic invertebrates appeared insufficient to support fish production in the Horokiwi Stream, New Zealand. Terrestrial subsidies may also influence trophic cascades, as shown by Nakano et al. (1999) who found that experimental reduction of terrestrial in-fall led to greater predation on aquatic invertebrates.

It has been suggested by previous researchers that large scale removal of canopy cover in these systems would likely decrease the input of terrestrial invertebrates to stream systems and food availability to stream fish (Sweka and Hartman 2008). Timber harvest has been shown to quickly decrease terrestrial invertebrate abundance, but abundances may increase to above pretimber harvest levels during regeneration in subsequent years (Schowalter et al. 1981). Our study provides evidence that headwater riparian deforestation can lead to reduced dependence of terrestrial food resources, possibly disrupting the headwater stream food web. With reductions in riparian forest cover, headwater food webs may function more like higher order, downstream reaches where there is naturally less canopy cover and greater autochthonous production. Headwater streams, which make up nearly $75 \%$ of stream miles in the United States (Leopold et al. 1964), play vital roles within the river continuum, and are tightly linked to downstream 
systems (Webster et al. 1999, Meyer and Wallace 2001, Gomi et al. 2002). Based on the evidence from our study that brook trout receive an important portion of their food supply from terrestrial in-fall and that the magnitude of this input varies with the amount of riparian vegetation, invertebrate subsidies of salmonid diet from riparian vegetation is an important consideration in management of streamside areas.

\section{Important prey items}

Brook trout exploited a variety of prey during the course of the study, exhibiting a generalist and opportunist pattern. Utz (2005) suggested that exploiting a variety of prey types increased the chances of maintaining body weight during stressful times (summer). By exploiting a range of prey brook trout may increase the chance that one of the prey organisms is disproportionately large in size and therefore offers more energy. While brook trout may have exhibited a generalist pattern of feeding certain prey items were found in greater proportions than others. In our study, Diptera, Decapoda, and Lepidoptera were the most important prey by mass and energy. However a different picture emerges when looking at abundance in which Ephemeroptera, Plecoptera, Trichoptera make up a substantial share of the diet. Previous researchers found similar results in central Appalachian streams especially in regards to the importance of Lepidoptera. Sweka (2003) found that during August, Lepidoptera (16\%), Hymenoptera (9\%), and Trichoptera (7\%), were the most important prey by mass while Diptera, Ephemeroptera, Trichoptera, and Hymenoptera made up the majority of the diet by abundance. Utz and Hartman (2007) found that during warmer months, terrestrial Lepidoptera were the most important prey by energy while Diptera, Aphidae, Formicidae, and Lepidoptera made up the 
majority of the diet by abundance. In Alaskan streams, Allen et al. (2003) found that Diptera, Plecoptera, Trichoptera, and Lepidoptera were the most important prey by mass for coho salmon. Our study concurs with Utz and Hartman (2007) that particular terrestrial organisms, may be of disproportionate importance relative to other prey items for brook trout. Of particular interest in this study and other studies of central Appalachian streams is the role that Lepidoptera appear to have in sustaining summer brook trout populations. The life history and behavior of Lepidoptera probably affect how brook trout acquire this particular prey. The larvae are large and thus are fairly conspicuous in the water column. In addition, the riparian habitat is dominated by broad-leafed species and Lepidoptera will often accidentally fall into the water while feeding or resting on overhanging vegetation. These streams have relatively small bankfull widths, and tree branches that span the entire stream making it likely that these organisms will fall into the streams. Lepidopterans are almost certainly important as a resource for maintaining brook trout populations as they provide a seasonally abundant food source during the summer. Webster and Hartman (2005) found that Lepidoptera larvae increased in brook trout dietary importance from July to September. During our study the proportion of Lepidoptera abundance, biomass and energy was significantly lower in brook trout diets in both $50 \%$ and $90 \%$ removal sections compared to reference sections. The differences in Lepidoptera between removal and reference sections show that the removal of forest canopy reduced Lepidoptera inputs to the stream. This suggests that harvest of riparian timber may have an effect on brook trout energetics, especially during summer.

The importance of terrestrial invertebrates to brook trout within summertime stream food webs is of great importance as aquatic prey tend to become less numerous during summer because of emergence (Hynes 1970). Limitations in summer food intake have previously been 
inferred or observed in Appalachian salmonids. Cada et al. (1987), Ensign et al. (1990), and Thorne (2004) observed a substantial drop in the number of items and/or mean stomach content weight found in brook trout stomachs from spring to summer in populations of Appalachian salmonids. Utz and Hartman (2006) found that terrestrial insect consumption by brook trout decreased as summer progressed yet remained greater than aquatic energy consumption. Reductions of terrestrial invertebrates within the stream food web are likely to result in decreased growth and possibly negative growth of Appalachian brook trout. Sweka and Hartman (2008) found through bioenergetics simulations that reducing the amount of terrestrial prey consumption reduced brook trout growth. They further suggested that a 50\% reduction in the terrestrial invertebrate component of the diet may result in negative growth during the summer months. Similarly, Gustafsson (2008) found that a 90\% reduction in summer terrestrial invertebrate subsides resulted in reduced growth of brown trout (Salmo trutta) in Swedish streams. The reduction we observed in terrestrial invertebrate consumption in removal sections may negatively impact brook trout growth and trout may not be able to compensate for this reduction by feeding solely on aquatic invertebrates (Sweka and Hartman 2008).

We found no study that has looked at the combined recovery of trout and terrestrial invertebrates in streams after clear-cut logging. Studies have focused on trout and benthic invertebrate productivity but not considered the importance of terrestrial invertebrates. Logging of riparian areas typically has increased benthic invertebrate and fish density for $10-15$ years post harvest due to increased light reaching the streambed (Murphy and Hall 1981, Hawkins et al 1983). Stone and Wallace (1998) found that sixteen years post harvest that benthic invertebrate abundance was three times higher in clear-cut streams than reference streams. Studies focused on trout and terrestrial invertebrate inputs in clear-cuts only looked at the differences between a 
specific time period and reference conditions. Studies from Alaska in young (35-50 years post harvest) and old growth forests did not find significant differences in the input of terrestrial inverterbrate biomass (Wipfli 1997, Allan et al 2003). The amount of basal area removed in a clear-cut may also play a role in stream recovery from riparian logging. Kreutzweiser et al. (2005) found that benthic invertebrate communities in low intensity harvest sites (29\% basal area removal) were similar to reference sites after 3 years post harvest. It may take several years of riparian growth before pre-harvest levels of terrestrial invertebrate input are re-established. The apparent importance of terrestrial organisms in our study that there are changes in brook trout diet in the canopy removal sections and these changes may persist for decades until riparian areas are re-forested. The reduction of terrestrial invertebrate availability to brook trout may result in decreased growth as well as reduced abundance of Appalachian brook trout in these sections. Future work should investigate the changes in trout density, benthic invertebrate productivity, and terrestrial invertebrate inputs associated with varying levels of timber harvest in these streams over a longer temporal scale (e.g. 5, 10, 15, 20, 25, 30 year). 


\section{References}

Allan, R. K. 1951. The Horokiwi stream: a study of a trout population. The New Zealand Marine Department of Fisheries Bulletin 10:1-231.

Allan, J. D. 1981. Determinants of diet of brook trout (Salvelinus fontinalis) in a mountain stream. Canadian Journal of Fisheries and Aquatic Sciences 38: 184-192.

Allen, J. D., M. S. Wipfli, J. P. Caouette, A. Prussian, and J. Rodgers. 2003. Influence of streamside vegetation on inputs of terrestrial invertebrates to salmonid food webs Canadian Journal of Fisheries and Aquatic Sciences 60:309-320.

Anderson, W. G., R. S. McKinley, and M. Colavechia. 1997. The use of clove oil as an anesthetic for rainbow trout and its effects on swimming performance. North American Journal of Fisheries Management 17:301-307.

Benke, A. C., A. D. Huryn, L. A. Smock, and J. B. Wallace. 1999. Length-mass relationships for freshwater macroinvertebrates in North America with particular reference to the southeastern United States. Journal of the North American Benthological Society 18:308343.

Bilby, R. E., and P. A. Bisson. 1992. Allochthonous versus authochthonous organic matter contributions to the trophic support of fish populations in clear-cut and old growth forested streams. Canadian Journal of Fisheries and Aquatic Sciences 49:540-551.

Cada, G. F., J. M. Loar, and M. J. Sale. 1987. Evidence of food limitation of rainbow and brown trout in southern Appalachian soft-water streams. Transactions of the American Fisheries Society 116:692-702.

Cadwallader, P. L., Eden, A. K., and R. A. Hook, 1980. Role of streamside vegetation as a food source for Galaxias olidus Günther (Pisces:Galaxidae). Australian Journal of Marine and Freshwater Research 31:257-262.

Clayton, J. L., E. S. Dannaway, R. Menendez, H. W. Rauch, J. J. Renton, S. M. Sherlock, and P. E. Zurbuch. 1998. Application of limestone to restore fish communities in acidified streams. North American Journal of Fisheries Management 18:347-360.

Clayton, J. L., and R. Menendez. 1998. Macroinvertebrate response to instream applications of fine grained limestone to mitigate acid deposition. USFWS progress report.

Cummins, K. C., and J. C. Wuycheck. 1971. Caloric equivalents for investigations in ecological energetics. Mitteilungen der Internationalen Vereinigung fur Theoretische und Angewandte Limnologie 18. 
Edwards, E. D., and Huryn, A. D. 1995. Annual contribution of terrestrial invertebrates to a New Zealand trout stream. New Zealand Journal of Marine and Freshwater Research 29:467477.

Edwards, E. D., and A. D. Huryn. 1996. Effect of riparian land use on contributions of terrestrial invertebrates to streams. Hydrobiologia 337:465-475.

Elliot, J. M. 1973. The food of brown and rainbow trout (Salmo trutta and S. gairdneri) in relation to the abundance of drifting invertebrates in a mountain stream. Oecologia $12: 329-347$.

Ensign, W. E., R. J. Strange, and S. E. Moore. 1990. Summer food limitation reduces brook and rainbow trout biomass in a southern Appalachian stream. Transactions of the American Fisheries Society 119:894-901.

Forrester, G. E., J. G. Chace, and W. McCarthy. 1994. Diel and density-related changes in food consumption and prey selection by brook charr in a New Hampshire stream. Environmental Biology of Fishes 39:301-311.

Gomi T., R. C. Sidle, and J. S. Richardson. 2002. Understanding processes and downstream linkages of headwater systems. BioScience 52:905-916.

Gustafsson, P. 2008. Forest-stream linkages: Experimental studies of foraging and growth of brown trout (Salmo trutta L). Master's Thesis, Karlstad University, Karlstad, Sweden.

Hetrick, N. J., M. A. Brusven, W. R. Meehan, and T. C. Bjornn. 1998. Changes in solar input, water temperature, periphyton accumulation, and allochthonous input and storage after canopy removal along two small salmon streams in southeast Alaska. Transactions of the American Fisheries Society 127:859-875.

Hubert, W. A., and H. A. Rhodes. 1989. Food selection by brook trout in a subalpine stream. Hydrobiologia 178:225-231.

Hynes, H .B .N., 1970. The ecology of running waters. University of Toronto Press, Toronto.

Johnston, T. A., and R. A. Cunjak. 1999. Dry mass-length relationships for benthic insects: a review with new data from Catamaran Brook, New Brunswick, Canada. Freshwater Biology 41:653-674.

Kawaguchi, Y., and S. Nakano. 2001. Contribution of terrestrial invertebrates to the annual resource budget for salmonids in forest and grassland reaches of a headwater stream. Freshwater Biology 46:303-316.

Kreutzweiser, D. P., S. S. Capell, and K. P. Good. 2004. Macroinvertebrate community responses to selection logging in riparian and upland areas of headwater catchments in a 
northern hardwood forest. Journal of the North American Benthological Society 24:208222.

Light, R. W., P. H. Adler, and D. E. Arnold. 1983. Evaluation of gastric lavage for stomach analyses. North American Journal of Fisheries Management 3:81-85.

Merritt, R. W., and K. W. Cummins. 1996. An introduction to the aquatic insects of North America, 3rd edition. Kendall and Hunt, Dubuque, Iowa.

Nakano, S., H. Miyasaka, and N. Kuhara. 1999. Terrestrial-aquatic linkages: riparian arthropod inputs alter trophic cascades in a stream food web. Ecology 80:2435-2441.

Sabo, J. L., J. L. Bastow, and M. E. Power. 2002. Length-mass relationships for adult aquatic and terrestrial invertebrates in a California watershed. Journal of the North American Benthological Society 21:336-343.

Sample, B. E., R. J. Cooper, R. D. Greer, and R. C. Whitmore. 1993. Estimation of insect biomass by length and weight. American Midland Naturalist 129:234-240.

Schowalter, T. D., J. W. Webb, and D. A. J. Crossley. 1981. Community structure and nutrient content of canopy arthropods in clearcut and uncut forest ecosystems. Ecology 62:10101019.

Studinski, J. M. 2010. The effect of riparian tree harvest intensity on biotic and abiotic stream characteristics. Doctoral dissertation. West Virginia University, Morgantown.

Sweka, J. A. 2003. Aquatic terrestrial linkages in Appalachian streams: influence of riparian inputs on stream habitat, brook trout populations, and trophic dynamics. Doctoral dissertation. West Virginia University, Morgantown.

Sweka, J. A., and K. J. Hartman. 2008. Contribution of terrestrial invertebrates to yearly brook trout prey consumption and growth. Transactions of the American Fisheries Society 137:224-235.

Tait, C. K., J. L. Li, G. A. Lamberti, T. N. Persons, and H. W. Li. 1994. Relationships between riparian cover and the community structure of high desert streams. Journal of the North American Benthological Society 13:45-56.

Thorne, D. W. 2004. Spatial and seasonal variation in brook trout diet, growth, and consumption in a complex Appalachian watershed. Master's thesis, West Virginia University, Morgantown.

Twomey, H., and P. S. Giller. 1990. Stomach flushing and individual Panjet tattooing of salmonids: an evaluation of the long-term effects on two wild populations. Aquaculture and Fisheries Management 21:137-142. 
Utz, R. M. 2005. Temporal trends in consumption, growth and successful feeding traits of a central Appalachian brook trout population at the watershed scale. Master's thesis. West Virginia University, Morgantown.

Utz, R. M., and K. J. Hartman. 2006. Temporal and spatial variation in the energy intake of a brook trout (Salvelinus fontinalis) population in an Appalachian stream. Canadian Journal of Fisheries and Aquatic Sciences 63:2675-2686.

Utz, R. M., and K. J. Hartman. 2007. Identification of critical prey items to Appalachian brook trout (Salvelinus fontinalis) with emphasis on terrestrial organisms. Hydrobiologia 575:259-270.

Vannote, R. L., G. W. Minshall, K. W. Cummins, J. R. Sedell, and C. E. Cushing. 1980. The river continuum concept. Canadian Journal of Fisheries and Aquatic Sciences 37:130137.

Vought, L. B. M., J. Dahl, C. R. Petersen, and J. O. Lacoursiere. 1994. Nutrient retention in riparian ecotones. Ambio 23:342-348.

Wallace, J. B. S. L. Eggert, J. L. Meyer, and J. R. Webster. 1997. Multiple trophic levels of a forest stream linked to terrestrial litter inputs. Science 277:102-104.

Weatherly, N. S., and S. J. Ormerod. 1990. Forests and the temperature of upland streams in Wales: A modeling exploration of the biological effects. Freshwater Biology 24:109-122.

Webster, J. J., and K. J. Hartman. 2005. The role of terrestrial invertebrates in allopatric brook trout headwater streams in the central Appalachian mountains. Journal of Freshwater Ecology 20:101-107.

West Virginia Division of Forestry. 2005. West Virginia silvicultural best management practices for controlling soil erosion and sedimentation from logging operations. WVDOF-TR-053, Charleston.

West Virginia Division of Natural Resources. 2001. Middle Fork River limestone treatment of acid mine drainage. Final Report, Elkins, West Virginia.

Wipfli, M. S. 1997. Terrestrial invertebrates as salmonid prey and nitrogen sources in streams: contrasting old-growth and young-growth riparian forests in southeastern Alaska, USA. Canadian Journal of Fisheries and Aquatic Sciences 54:1259-1269. 
Table 1. Summary descriptive stream statistics of the four study streams in the Middle Fork River watershed, Randolph County, West Virginia (August 2007).

\begin{tabular}{lccccc}
\hline Stream & $\begin{array}{c}\text { Stream } \\
\text { Order }\end{array}$ & $\begin{array}{c}\text { Mean wetted } \\
\text { width }(\mathrm{m})\end{array}$ & $\begin{array}{c}\text { Mean } \\
\text { Gradient }(\%)\end{array}$ & $\begin{array}{c}\text { Mean } \\
\text { Elevation }(\mathrm{m})\end{array}$ & $\begin{array}{c}\text { Removal } \\
\text { Treatment }\end{array}$ \\
\hline Birch Fork & 2 & 3.22 & 2.92 & 847 & 50 \\
Mitchell Lick & 1 & 2.01 & 3.98 & 810 & 90 \\
North Panther Run & 1 & 2.57 & 3.90 & 749 & 50 \\
Schoolcraft Run & 2 & 2.97 & 2.89 & 737 & 90 \\
\hline
\end{tabular}


Table 2. Dates of sample and number of brook trout diet samples in the Middle Fork River, West Virginia during 2007.

\begin{tabular}{cccccccccc}
\hline & & \multicolumn{3}{c}{$50 \%$ removal streams } & \multicolumn{3}{c}{ 90\% removal streams } \\
Week & Date & \multicolumn{2}{c}{ Birch } & \multicolumn{2}{c}{ North Panther } & \multicolumn{2}{c}{ Mitchell } & \multicolumn{2}{c}{ Schoolcraft } \\
\hline & & Removal & Reference & Removal & Reference & Removal & Reference & Removal & Reference \\
1 & $7 / 25$ & 14 & 14 & 20 & 20 & 20 & 20 & 20 & 20 \\
2 & $8 / 9$ & 17 & 17 & 16 & 16 & 20 & 20 & 20 & 20 \\
3 & $8 / 17$ & 14 & 14 & 20 & 20 & 20 & 20 & 14 & 14 \\
\hline
\end{tabular}


Table 3. Energy densities by dry weight (DW) of prey types encountered in brook trout stomachs (from Cummins and Wuycheck 1971).

\begin{tabular}{|c|c|c|c|}
\hline Order & Life History & Stage & $\begin{array}{l}\text { Energy Density } \\
\text { (calories g }{ }^{-1} \text { DW) }\end{array}$ \\
\hline Caudata & Aquatic & Adult & 1638 \\
\hline Coleoptera & Aquatic & Adult & 5371 \\
\hline Coleoptera & Aquatic & Larval & 5371 \\
\hline Collembola & Aquatic & Adult & 6063 \\
\hline Decapoda & Aquatic & Adult & 4890 \\
\hline Diptera & Aquatic & Adult & 4276 \\
\hline Diptera & Aquatic & Larval & 4276 \\
\hline Ephemeroptera & Aquatic & Adult & 5469 \\
\hline Ephemeroptera & Aquatic & Larval & 5469 \\
\hline Hemiptera & Aquatic & Adult & 5638 \\
\hline Megaloptera & Aquatic & Adult & 5210 \\
\hline Megaloptera & Aquatic & Larval & 5210 \\
\hline Odonata & Aquatic & Adult & 3034 \\
\hline Odonata & Aquatic & Larval & 3034 \\
\hline Oligochaetae & Aquatic & Adult & 5575 \\
\hline Plecoptera & Aquatic & Adult & 4823 \\
\hline Plecoptera & Aquatic & Larval & 4823 \\
\hline Salmonidae & Aquatic & Adult & 3660 \\
\hline Trichoptera & Aquatic & Adult & 4999 \\
\hline Trichoptera & Aquatic & Larval & 4999 \\
\hline Acari & Terrestrial & Adult & 5808 \\
\hline Aranae & Terrestrial & Adult & 4825 \\
\hline Blattodeae & Terrestrial & Adult & 5347 \\
\hline Coleoptera & Terrestrial & Adult & 5556 \\
\hline Coleoptera & Terrestrial & Larval & 5556 \\
\hline Diptera & Terrestrial & Adult & 5783 \\
\hline Diptera & Terrestrial & Larval & 5783 \\
\hline Haplotaxida & Terrestrial & Adult & 4569 \\
\hline Hemiptera & Terrestrial & Adult & 5638 \\
\hline Homoptera & Terrestrial & Adult & 5638 \\
\hline Hymenoptera & Terrestrial & Adult & 4629 \\
\hline Lepidoptera & Terrestrial & Adult & 5570 \\
\hline Lepidoptera & Terrestrial & Larval & 5250 \\
\hline Mecoptera & Terrestrial & Adult & 5454 \\
\hline Neuroptera & Terrestrial & Adult & 5454 \\
\hline Opiliones & Terrestrial & Adult & 4825 \\
\hline Orthoptera & Terrestrial & Adult & 5077 \\
\hline Psocoptera & Terrestrial & Adult & 5454 \\
\hline Spirobola & Terrestrial & Adult & 5453 \\
\hline
\end{tabular}


Table 4. Mean abundance proportion of 10 most common prey taxa in removal and reference sections. Results of MANOVA between mean proportions per taxa are provided. P-values with an asterisk denote a significant difference at the 0.05 level.

\begin{tabular}{|c|c|c|c|c|c|c|c|}
\hline \multirow[b]{2}{*}{ Treatment } & \multirow[b]{2}{*}{ Order } & \multirow{2}{*}{$\begin{array}{c}\text { Life History } \\
(\text { (A or T) }\end{array}$} & \multicolumn{2}{|c|}{ Removal } & \multicolumn{2}{|c|}{ Reference } & \multirow[b]{2}{*}{$p$} \\
\hline & & & Mean & SE & Mean & SE & \\
\hline \multicolumn{8}{|l|}{$50 \%$} \\
\hline & Fish \& Amphibians & Aquatic & 0.0048 & 0.0013 & 0.0000 & 0.0000 & 0.4906 \\
\hline & Coleoptera & Terrestrial & 0.0810 & 0.0186 & 0.0562 & 0.0153 & 0.9156 \\
\hline & Decapoda & Aquatic & 0.0365 & 0.0095 & 0.0123 & 0.0112 & 0.9999 \\
\hline & Diptera & Terrestrial & 0.0968 & 0.0176 & 0.1356 & 0.0239 & 0.4166 \\
\hline & Lepidoptera & Terrestrial & 0.1397 & 0.0222 & 0.1945 & 0.0652 & 0.1771 \\
\hline & EPT & Aquatic & 0.2762 & 0.0437 & 0.2151 & 0.0089 & 0.5057 \\
\hline & Hymenoptera & Terrestrial & 0.0873 & 0.0168 & 0.0781 & 0.0184 & 0.6349 \\
\hline & Megaloptera & Terrestrial & 0.0063 & 0.0025 & 0.0082 & 0.0031 & 0.9734 \\
\hline & Diptera & Aquatic & 0.1508 & 0.0950 & 0.1726 & 0.0403 & 0.7325 \\
\hline & Orthoptera & Terrestrial & 0.0111 & 0.0030 & 0.0041 & 0.0021 & 0.5506 \\
\hline & Other & Aquatic & 0.0190 & 0.0082 & 0.0205 & 0.0017 & 0.9999 \\
\hline & Other & Terrestrial & 0.0873 & 0.0028 & 0.1027 & 0.0033 & 0.9318 \\
\hline $90 \%$ & Fish \& Amphibians & Aquatic & 0.0022 & 0.0007 & 0.0028 & 0.0010 & 0.9612 \\
\hline & Coleoptera & Terrestrial & 0.0381 & 0.0120 & 0.0593 & 0.0119 & 0.5987 \\
\hline & Decapoda & Aquatic & 0.0191 & 0.0142 & 0.0083 & 0.0065 & 0.3879 \\
\hline & Diptera & Terrestrial & 0.1166 & 0.0349 & 0.1117 & 0.0193 & 0.5147 \\
\hline & Lepidoptera & Terrestrial & 0.0460 & 0.0206 & 0.1807 & 0.0503 & $0.0013 *$ \\
\hline & EPT & Aquatic & 0.5179 & 0.0499 & 0.2938 & 0.0176 & $0.0239 *$ \\
\hline & Hymenoptera & Terrestrial & 0.0762 & 0.0266 & 0.0634 & 0.0145 & 0.3980 \\
\hline & Megaloptera & Terrestrial & 0.0000 & 0.0000 & 0.0000 & 0.0000 & 1.0000 \\
\hline & Diptera & Aquatic & 0.1166 & 0.0201 & 0.1821 & 0.0393 & 0.9903 \\
\hline & Orthoptera & Terrestrial & 0.0034 & 0.0013 & 0.0097 & 0.0035 & 0.1366 \\
\hline & Other & Aquatic & 0.0123 & 0.0008 & 0.0055 & 0.0003 & 0.4023 \\
\hline & Other & Terrestrial & 0.0516 & 0.0014 & 0.0828 & 0.0023 & 0.3043 \\
\hline
\end{tabular}


Table 5. Mean biomass proportion of 10 most common prey taxa in removal and reference sections. Results of MANOVA between mean proportions per taxa are provided. P-values with an asterisk denote a significant difference at the 0.05 level.

\begin{tabular}{|c|c|c|c|c|c|c|c|}
\hline \multirow[b]{2}{*}{ Treatment } & \multirow[b]{2}{*}{ Order } & \multirow{2}{*}{$\begin{array}{l}\text { Life History } \\
\text { (A or T) }\end{array}$} & \multicolumn{2}{|c|}{ Removal } & \multicolumn{2}{|c|}{ Reference } & \multirow[b]{2}{*}{$p$} \\
\hline & & & Mean & SE & Mean & SE & \\
\hline $50 \%$ & & & & & & & \\
\hline & Fish \& Amphibians & Aquatic & 0.0289 & 0.0178 & 0.0000 & 0.0000 & 0.8149 \\
\hline & Coleoptera & Terrestrial & 0.0289 & 0.0096 & 0.0565 & 0.0376 & 0.9714 \\
\hline & Decapoda & Aquatic & 0.7243 & 0.1569 & 0.3787 & 0.1103 & $0.0247 *$ \\
\hline & Diptera & Terrestrial & 0.0163 & 0.0111 & 0.0569 & 0.0470 & 0.2258 \\
\hline & Lepidoptera & Terrestrial & 0.0998 & 0.0146 & 0.3239 & 0.1464 & $0.0423 *$ \\
\hline & EPT & Aquatic & 0.0150 & 0.0027 & 0.0149 & 0.0013 & 0.8669 \\
\hline & Hymenoptera & Terrestrial & 0.0085 & 0.0078 & 0.0687 & 0.0234 & 0.9924 \\
\hline & Megaloptera & Terrestrial & 0.0046 & 0.0031 & 0.0368 & 0.0266 & 0.7994 \\
\hline & Diptera & Aquatic & 0.0046 & 0.0021 & 0.0048 & 0.0027 & 0.9997 \\
\hline & Orthoptera & Terrestrial & 0.0322 & 0.0126 & 0.0066 & 0.0070 & 0.6929 \\
\hline & Other & Aquatic & 0.0042 & 0.0088 & 0.0097 & 0.0007 & 0.7819 \\
\hline & Other & Terrestrial & 0.0327 & 0.0020 & 0.0424 & 0.0056 & 0.9519 \\
\hline & Fish \& Amphibians & Aquatic & \multicolumn{4}{|c|}{$90 \%$} & 0.9469 \\
\hline & Coleoptera & Terrestrial & 0.0426 & 0.0491 & 0.1069 & 0.0305 & 0.9999 \\
\hline & Decapoda & Aquatic & 0.4650 & 0.0862 & 0.2296 & 0.0708 & $0.0425 *$ \\
\hline & Diptera & Terrestrial & 0.0232 & 0.0182 & 0.0597 & 0.0249 & 0.6289 \\
\hline & Lepidoptera & Terrestrial & 0.1497 & 0.0419 & 0.3205 & 0.1032 & $0.0473 *$ \\
\hline & EPT & Aquatic & 0.0599 & 0.0076 & 0.0338 & 0.0021 & 0.0526 \\
\hline & Hymenoptera & Terrestrial & 0.0304 & 0.0186 & 0.0502 & 0.0242 & 0.7909 \\
\hline & Megaloptera & Terrestrial & 0.0000 & 0.000 & 0.0000 & 0.0000 & 1.0000 \\
\hline & Diptera & Aquatic & 0.1226 & 0.0593 & 0.0132 & 0.0046 & $0.0171 *$ \\
\hline & Orthoptera & Terrestrial & 0.0184 & 0.0086 & 0.0495 & 0.0295 & 0.0647 \\
\hline & Other & Aquatic & 0.0076 & 0.0006 & 0.0055 & 0.0007 & 0.8306 \\
\hline & Other & Terrestrial & 0.0152 & 0.0036 & 0.0346 & 0.0013 & 0.9992 \\
\hline
\end{tabular}


Table 6. Mean energy proportion of 10 most common prey taxa in removal and reference sections. Results of MANOVA between mean proportions per taxa are provided. P-values with an asterisk denote a significant difference at the 0.05 level.

\begin{tabular}{clcccccc}
\hline \multirow{2}{*}{ Treatment } & \multicolumn{1}{c}{ Order } & Life History & \multicolumn{2}{c}{ Removal } & \multicolumn{2}{c}{ Reference } \\
(A or T) & Mean & SE & Mean & SE & \multicolumn{1}{c}{$\boldsymbol{p}$} \\
\hline $50 \%$ & & & & & & & \\
& Fish \& Amphibians & Aquatic & 0.0096 & 0.0068 & 0.0000 & 0.0000 & 0.7405 \\
& Coleoptera & Terrestrial & 0.0328 & 0.0104 & 0.0614 & 0.0394 & 0.9794 \\
& Decapoda & Aquatic & 0.7229 & 0.1585 & 0.3625 & 0.1094 & $0.0354 *$ \\
& Diptera & Terrestrial & 0.0192 & 0.0122 & 0.0644 & 0.0517 & 0.2555 \\
& Lepidoptera & Terrestrial & 0.1069 & 0.0145 & 0.3328 & 0.1459 & $0.0448 *$ \\
& EPT & Aquatic & 0.0158 & 0.0028 & 0.0150 & 0.0012 & 0.7895 \\
& Hymenoptera & Terrestrial & 0.0086 & 0.0071 & 0.0622 & 0.0220 & 0.9901 \\
& Megaloptera & Terrestrial & 0.0049 & 0.0032 & 0.0375 & 0.0269 & 0.8051 \\
& Diptera & Aquatic & 0.0042 & 0.0020 & 0.0042 & 0.0023 & 0.9999 \\
& Orthoptera & Terrestrial & 0.0334 & 0.0128 & 0.0065 & 0.0066 & 0.6816 \\
& Other & Aquatic & 0.0051 & 0.0015 & 0.0106 & 0.0008 & 0.8940 \\
& Other & Terrestrial & 0.0366 & 0.0021 & 0.0429 & 0.0052 & 0.9794 \\
& & & & & & \\
& Fish \& Amphibians & Aquatic & 0.0062 & 0.0028 & 0.0327 & 0.0081 & 0.7285 \\
Coleoptera & Terrestrial & 0.0511 & 0.0558 & 0.1230 & 0.0340 & 0.9999 \\
& Decapoda & Aquatic & 0.4888 & 0.0836 & 0.2321 & 0.0785 & 0.1582 \\
& Diptera & Terrestrial & 0.0289 & 0.0203 & 0.0714 & 0.0281 & 0.6141 \\
& Lepidoptera & Terrestrial & 0.1689 & 0.0468 & 0.3478 & 0.1049 & $0.0473 *$ \\
EPT & Aquatic & 0.0663 & 0.0074 & 0.0362 & 0.0037 & $0.0254 *$ \\
Hymenoptera & Terrestrial & 0.0302 & 0.0175 & 0.0480 & 0.0218 & 0.8102 \\
Megaloptera & Terrestrial & 0.0000 & 0.0000 & 0.0000 & 0.0000 & 1.0000 \\
Diptera & Aquatic & 0.1129 & 0.0518 & 0.0120 & 0.0039 & $0.0140 *$ \\
Orthoptera & Terrestrial & 0.0200 & 0.0093 & 0.0519 & 0.0289 & 0.0727 \\
Other & Aquatic & 0.0093 & 0.0007 & 0.0064 & 0.0008 & 0.7717 \\
Other & Terrestrial & 0.0174 & 0.0038 & 0.0384 & 0.0013 & 0.9984 \\
& & & & & & \\
\hline & & & & & & &
\end{tabular}


Table 7. Spearman's rank correlation $\left(r_{s}\right)$ for comparison of terrestrial taxa in brook trout diets and pan traps in removal and reference sections. Results of rank correlation tests are provided. Pvalues with an asterisk denote a significant difference at the 0.05 level.

\begin{tabular}{lclcc}
\hline Variable & Treatment & Section & $\boldsymbol{r}_{\boldsymbol{s}}$ & $\boldsymbol{p}$ \\
\hline Abundance & $50 \%$ & & & \\
& & Removal & 0.694 & $0.006^{*}$ \\
& & Reference & 0.824 & $0.001^{*}$ \\
& & & 0.850 & $0.000^{*}$ \\
& & Removal & 0.814 & $0.000^{*}$ \\
Biomass & Reference & & \\
& & & 0.624 & $0.017^{*}$ \\
& $50 \%$ & Removal & 0.693 & $0.006^{*}$ \\
& & Reference & 0.899 & $0.000^{*}$ \\
& \multirow{2}{*}{$90 \%$} & Removal & 0.819 & $0.000^{*}$ \\
\hline
\end{tabular}



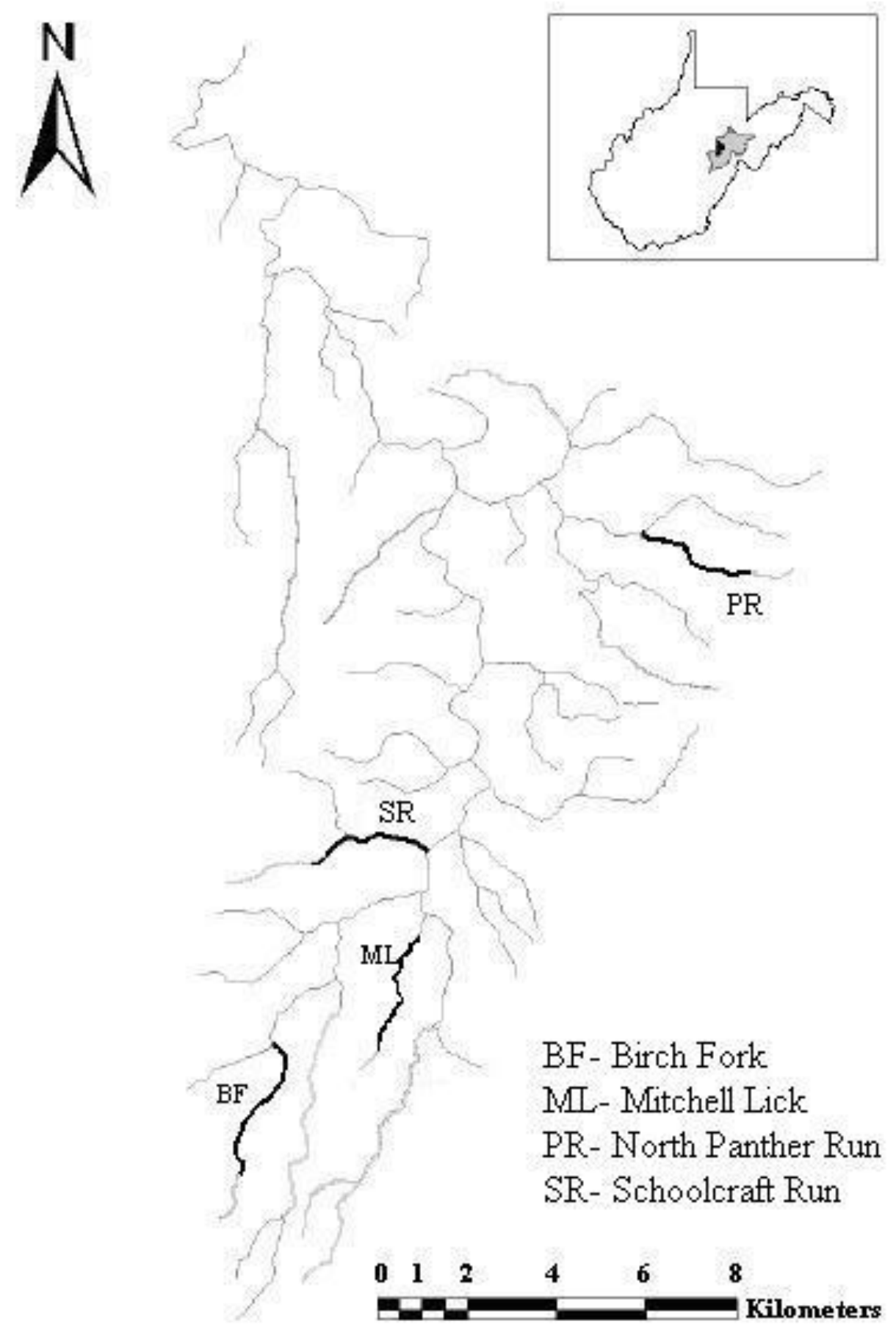

Figure 1. Middle Fork River Watershed, Randolph County, West Virginia and the location of the four study streams. 


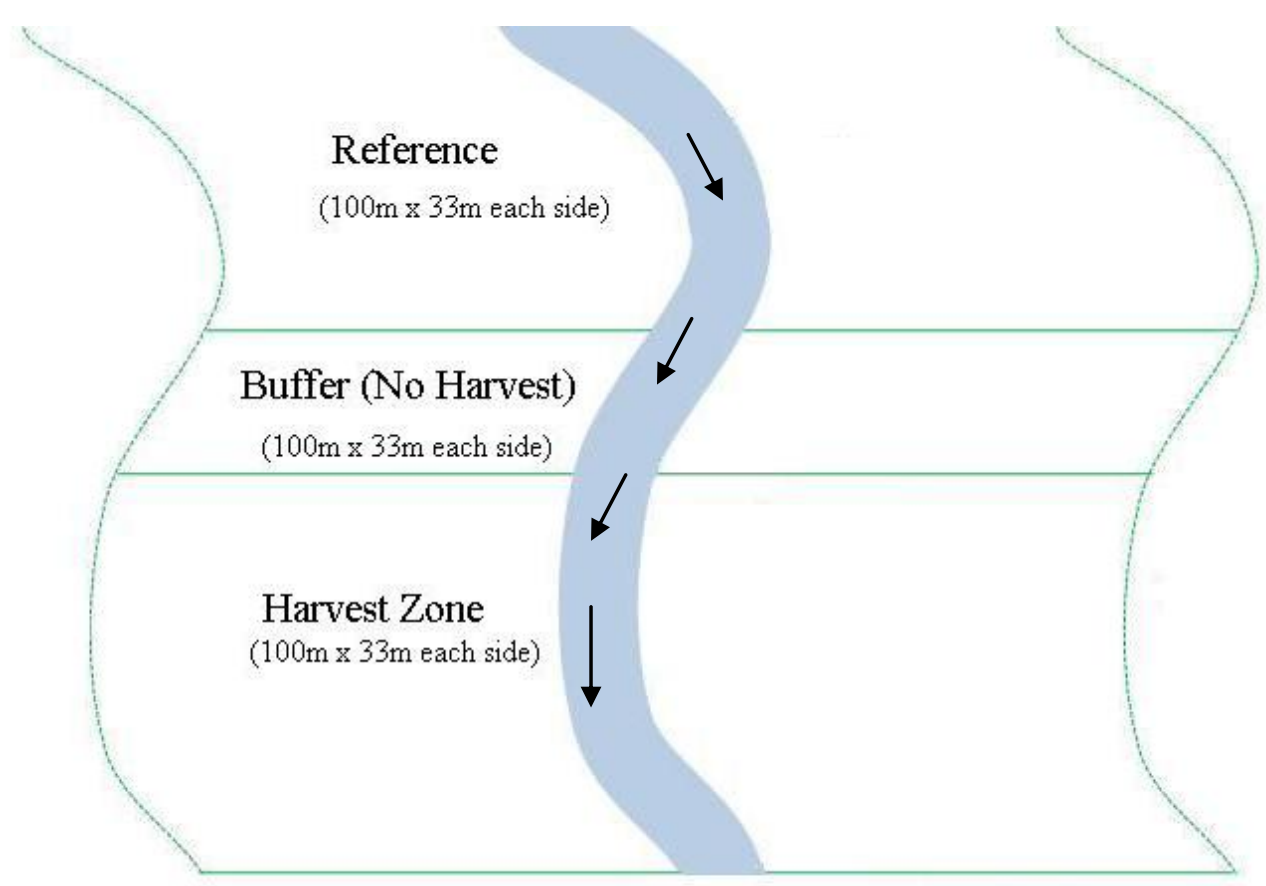

Figure 2. Schematic diagram of the study stream sections in four tributaries of the Middle Fork River, West Virginia. Arrows represent direction of stream flow. 

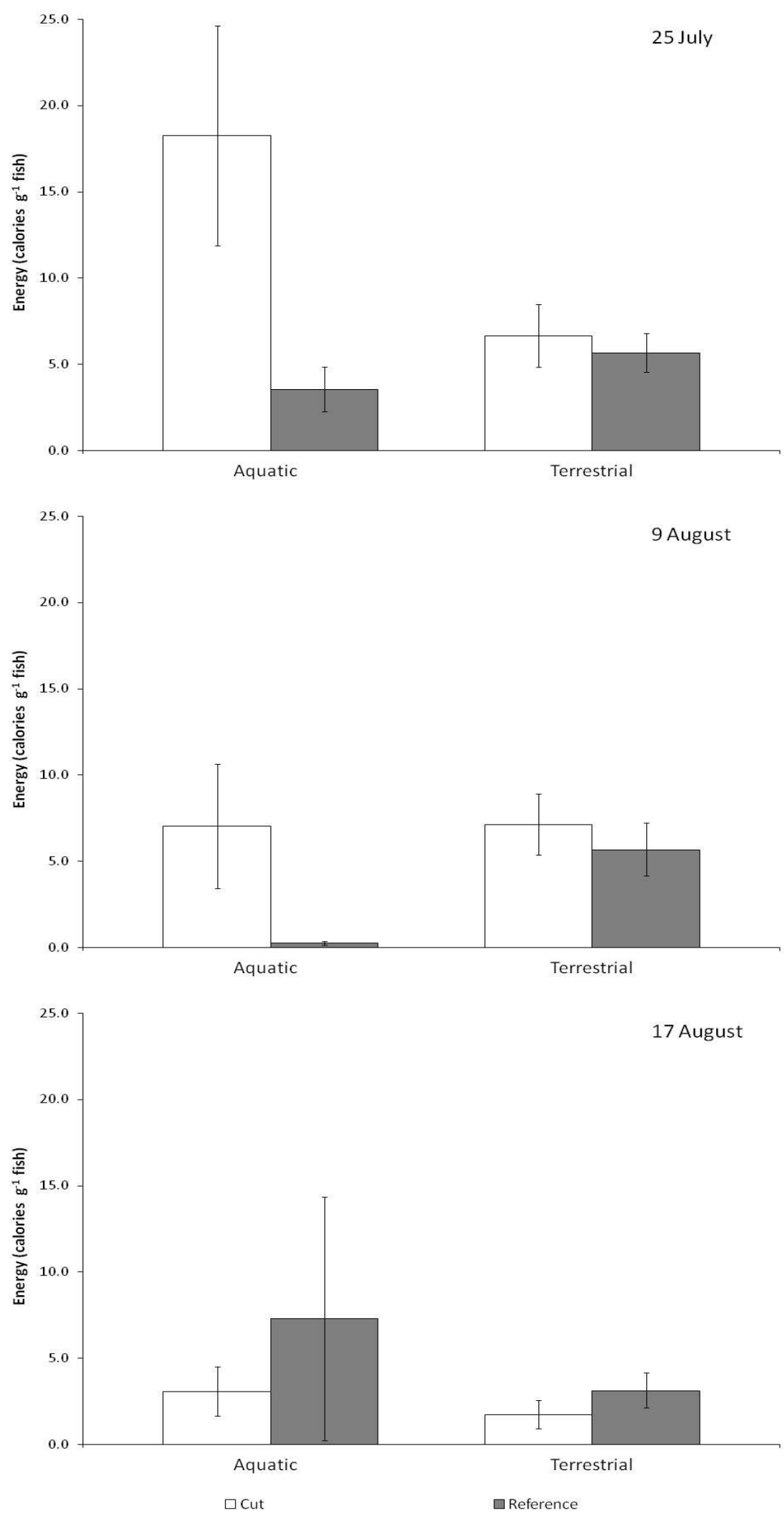

Figure 3. Mean energy (calories $\mathrm{g}^{-1}$ fish) consumption by prey source during each week in $50 \%$ removal streams. Bars represent \pm 1 standard error. 

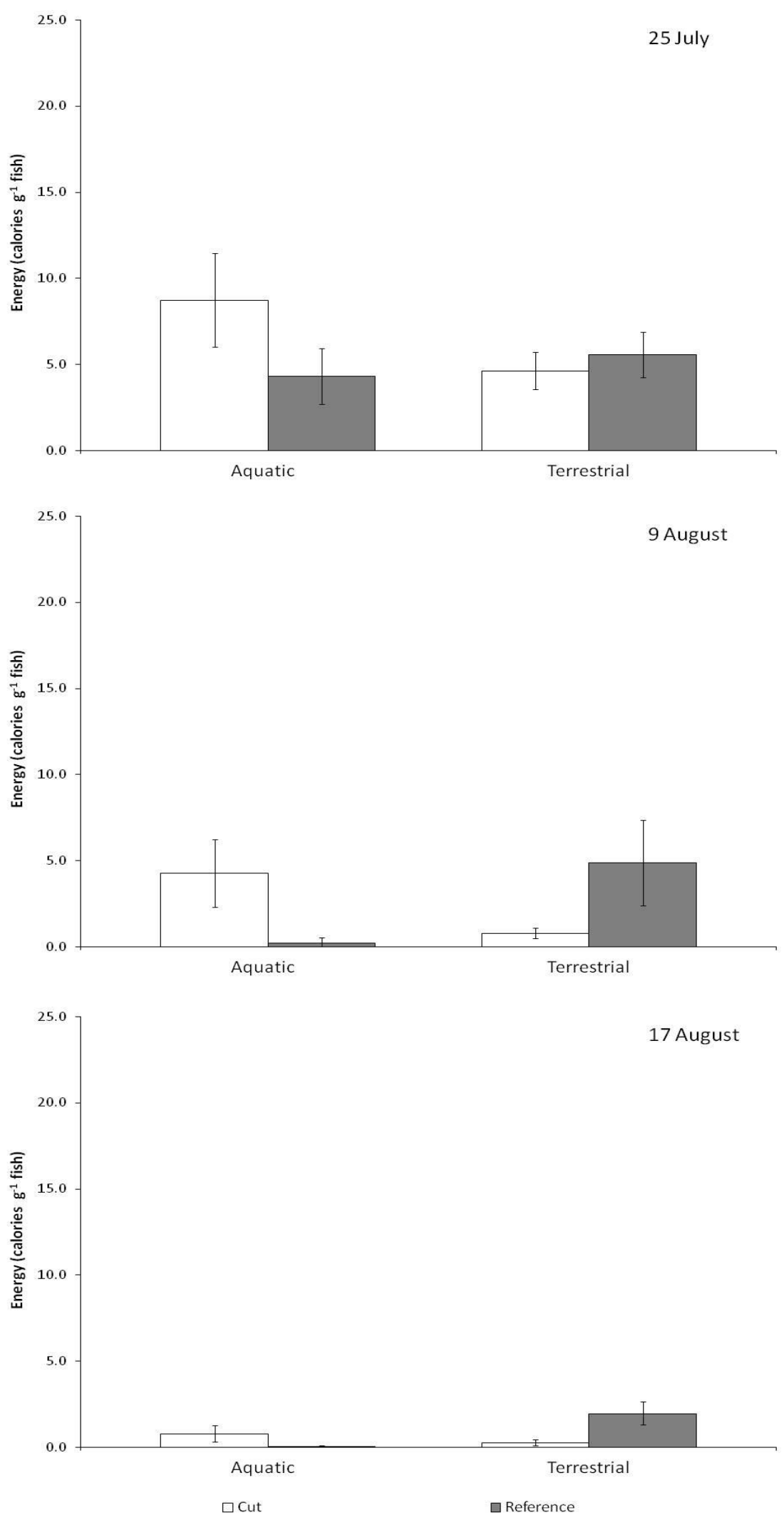

Figure 4. Mean energy (calories $\mathrm{g}^{-1}$ fish) consumption by prey source during each week in $90 \%$ removal streams. Bars represent \pm 1 standard error. 

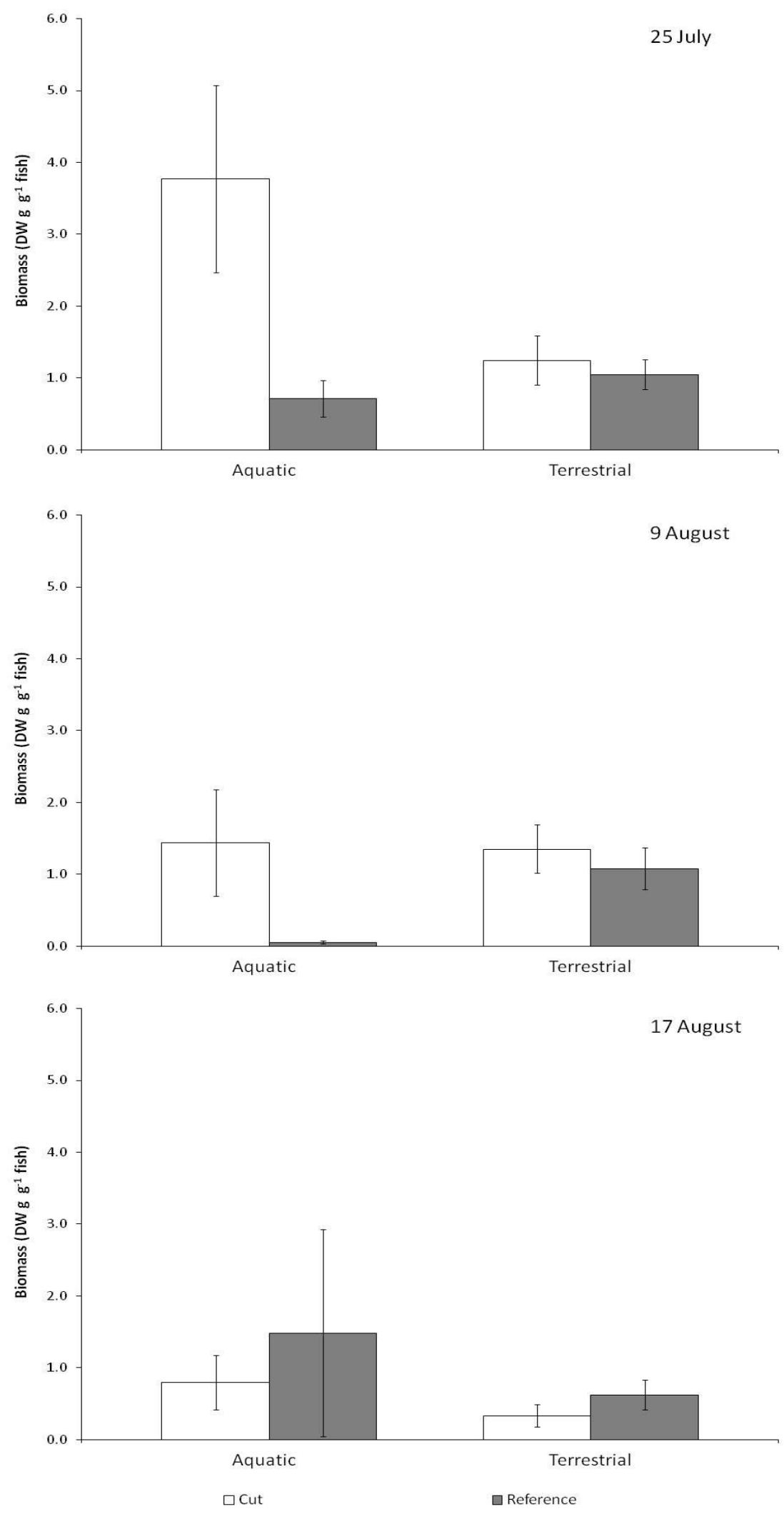

Figure 5. Mean biomass (DW $\mathrm{g} \mathrm{g}^{-1}$ fish) consumption by prey source during each week in $50 \%$ removal streams. Bars represent \pm 1 standard error. 

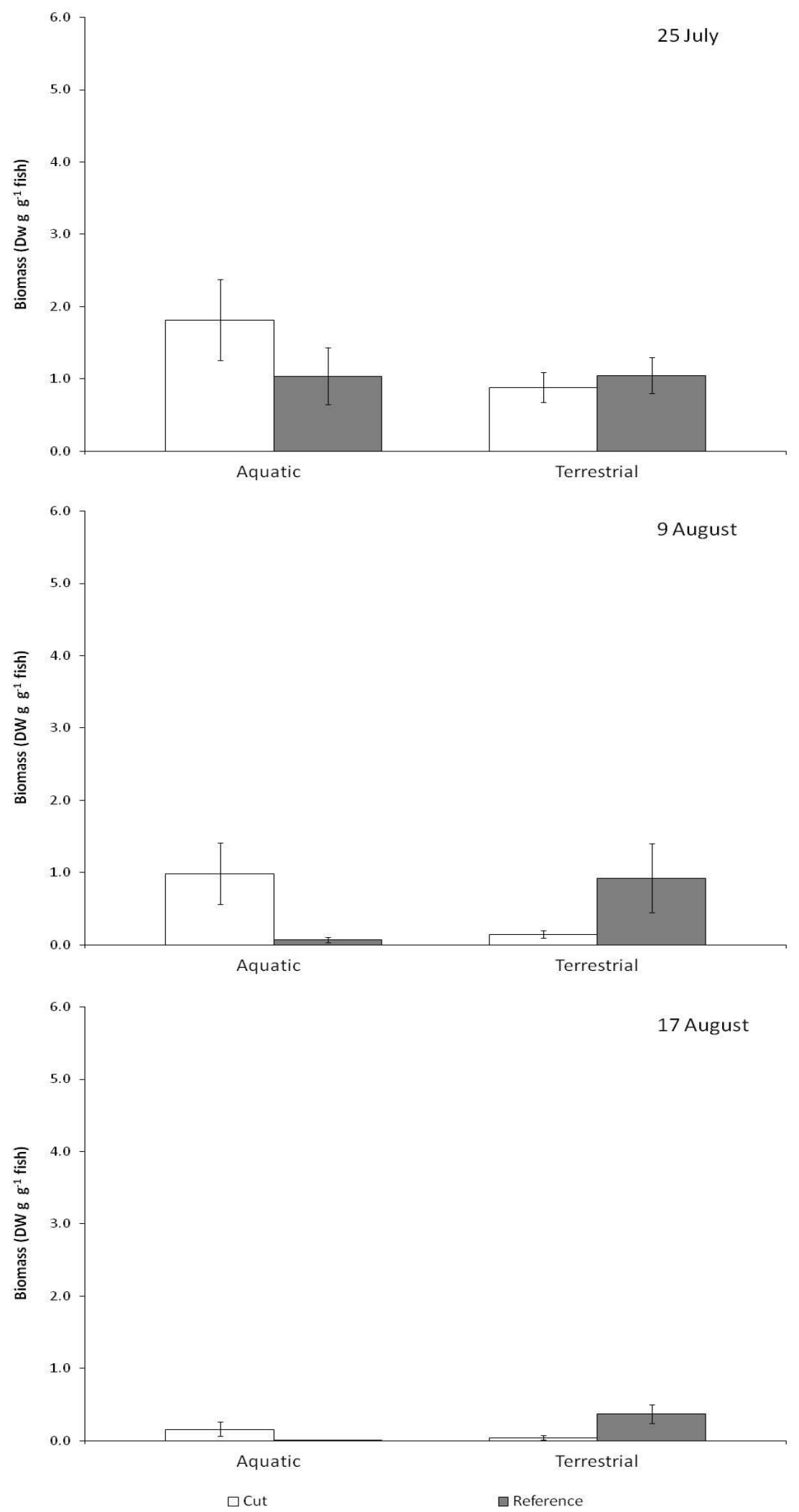

Figure 6. Mean biomass (DW $\mathrm{g} \mathrm{g}^{-1}$ fish) consumption by prey source during each week in $90 \%$ removal streams. Bars represent \pm 1 standard error. 


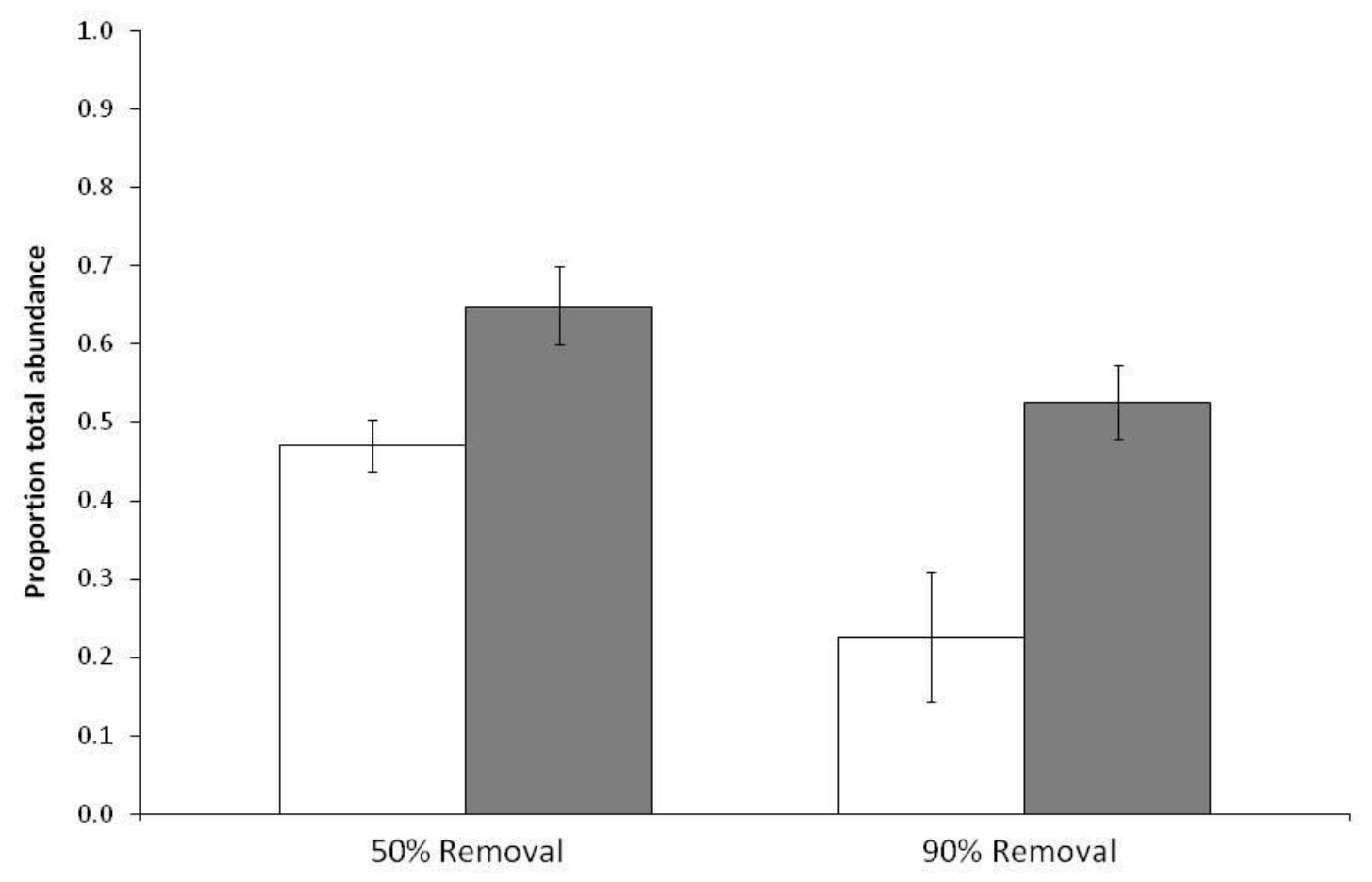

$\square$ Cut $\square$ Reference

Figure 7. Proportional number of terrestrial invertebrate prey ingested by brook trout for $50 \%$ and $90 \%$ removal treatments and reference sites. Values $=($ TI number $) /($ TI number $+\mathrm{AI}$ number). Bars represent \pm 1 standard error. 


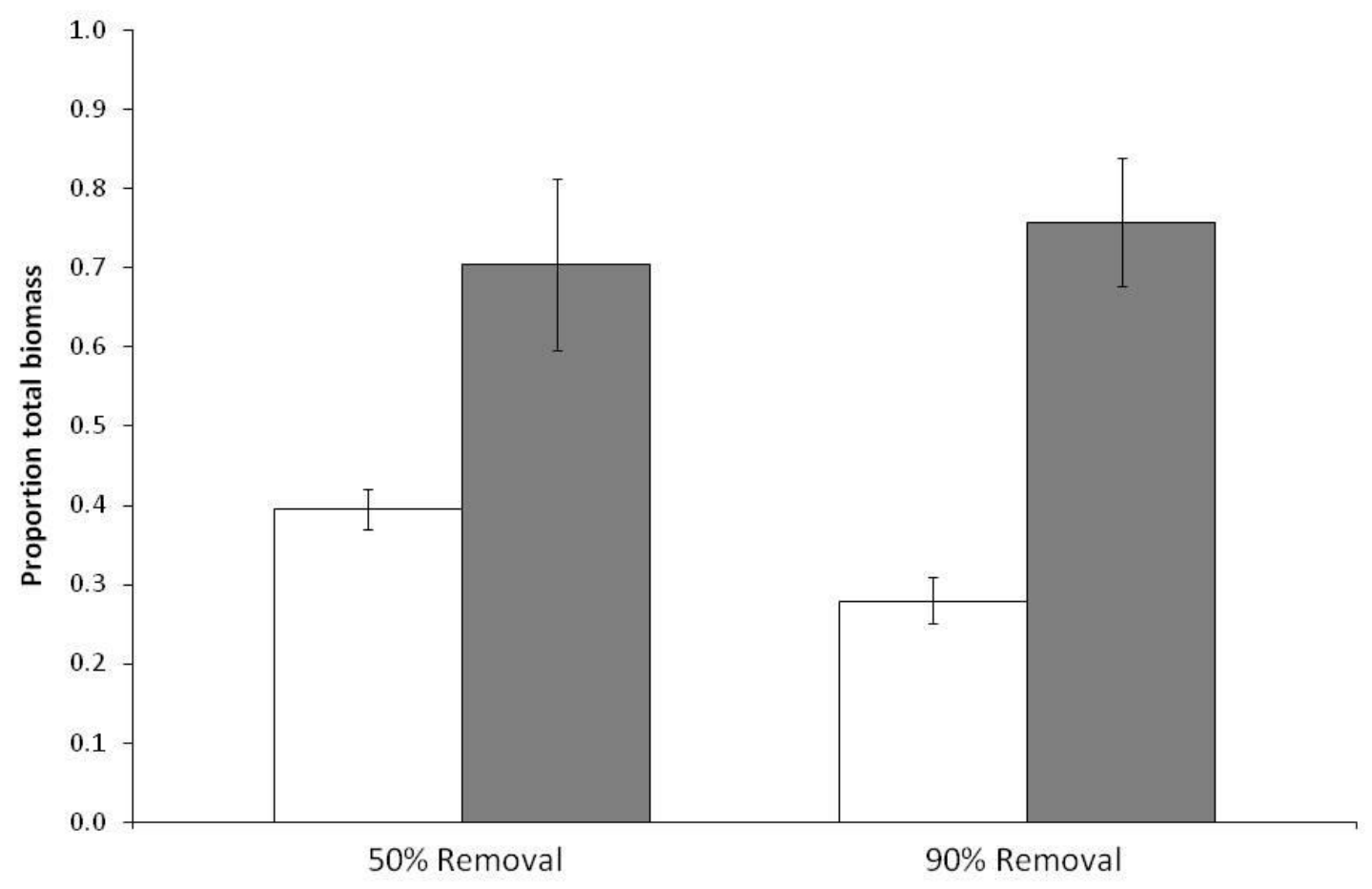

$\square$ Cut $\square$ Reference

Figure 8. Proportional mass of terrestrial invertebrate prey ingested by brook trout for $50 \%$ and $90 \%$ removal treatments and reference sites. Values $=($ TI mass $) /($ TI mass + AI mass $)$. Bars represent \pm 1 standard error. 


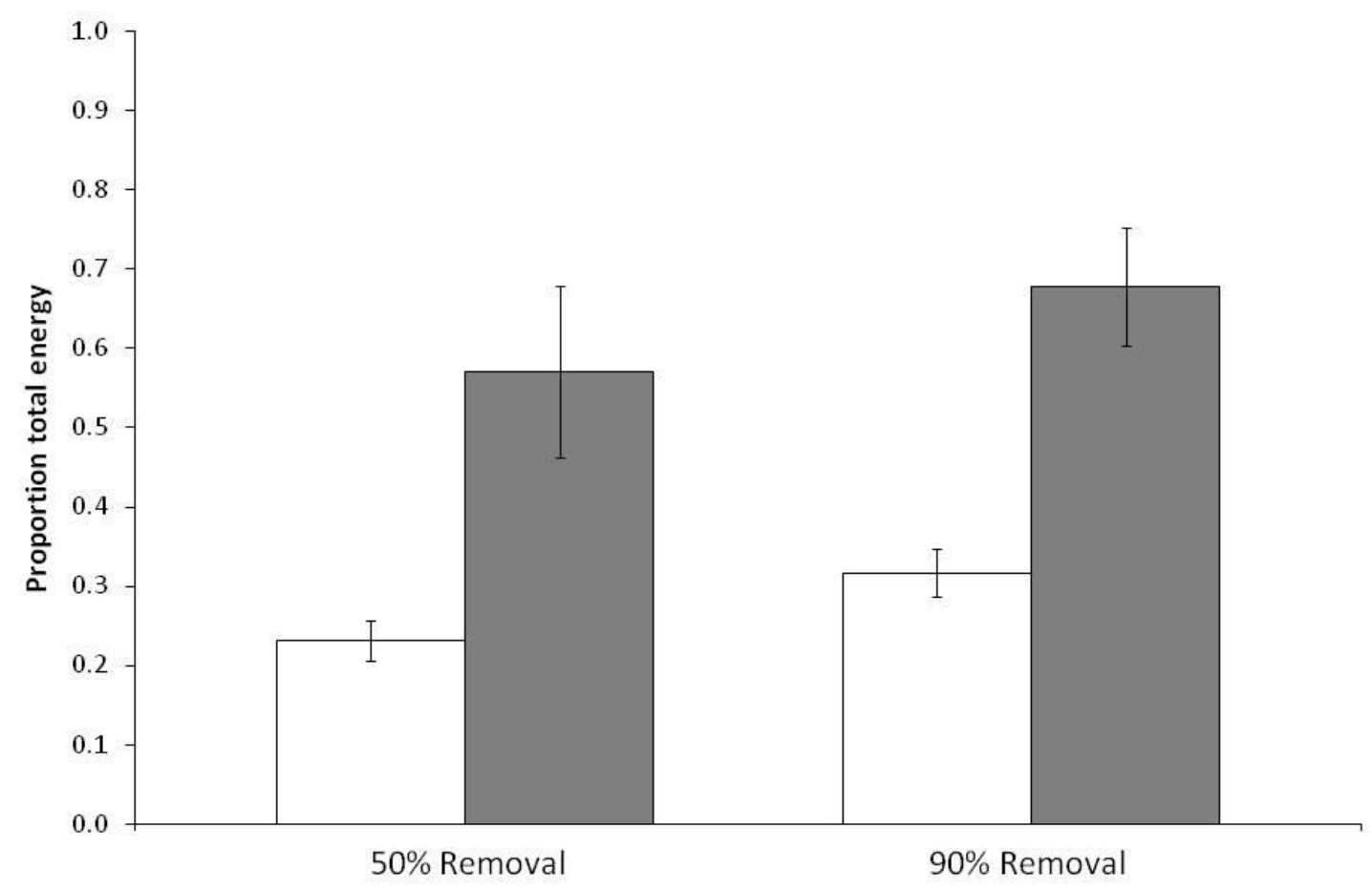

$\square$ Cut $\square$ Reference

Figure 9. Proportional energy (calories $\mathrm{g}^{-1} \mathrm{DW}$ ) of terrestrial invertebrate prey ingested by brook trout for 50\% and 90\% removal treatments and reference sites. Values $=($ TI energy $) /($ TI energy $+\mathrm{AI}$ energy). Bars represent \pm 1 standard error. 
Chapter 5: Management Implications and Recommendations for Best Management Practices.

West Virginia is the third most forested state in the United States, with forest covering $78.0 \%$ of the state's 15.4 million acres of land. Almost all of the forested land $(98.3 \%)$ is classified as commercial forestland, which is available for timber production. Forestry is important to the economy of West Virginia with the economic impact of forestry production exceeding \$4 billion dollars annually (Childs 2005). In addition, other forest-based activities generate billions of additional dollars for the state's economy. These activities include recreation (hunting, fishing, wildlife watching, hiking, biking, sightseeing, etc.), and the gathering and selling of forest products (ginseng, Christmas trees, mushrooms, etc.).

Streams in this region of central Appalachia are also highly valued because they support recreational trout fisheries. Local rural economies are dependent upon the continued existence of trout fisheries. In West Virginia, the total economic impact of all freshwater angling is estimated to be over $\$ 333$ million dollars annually (USFWS 1996). Given that over $30 \%$ of the more than 30 million freshwater anglers in the U.S. fish for inland trout (Boyle et al. 1996), the economic impact of trout stream resources to the economy of West Virginia cannot be ignored.

The strong connectivity between terrestrial and aquatic ecosystems means that anthropogenic alteration of the landscape will unavoidably affect stream and river systems. Unfortunately, watershed disturbance is certainly inevitable because of the needs of economic systems. Freshwater ecosystems are vital to economies because of the millions of dollars in ecosystem services they provide to society each year (Wilson and Carpenter 1999). Consequently, protection and management of riparian areas is critical to prevent degradation of these valuable freshwater ecosystems. While establishing the importance of riparian forest cover 
is relatively straight forward, riparian buffer policy and management decisions are complicated as they must balance ecological values with economic and societal values. Riparian areas are some of the best sites for producing high quality wood products. The unharvested timber left in SMZs can represent a substantial financial loss to landowners (Shaffer and Aust 1993, Kilgore and Blinn 2003, LeDoux 2006). Within the mid-Atlantic region over $80 \%$ of the watershed area associated with $1^{\text {st }}$ and $2^{\text {nd }}$ order streams is forested (Thornton et al 2000). It is estimated that up to $70 \%$ of the merchantable timber in West Virginia is within streamside management zones (SMZ), thus it is these areas that are likely to be targeted for timber harvest (West Virginia Division of Forestry, 2005).

\section{Riparian tree removal}

West Virginia along with several southeastern U.S. states, allows timber harvesting within SMZs. Limits on harvest of timber in the southeast vary by state. West Virginia has no current harvesting restriction within the streamside management zone. While West Virginia has not adopted harvesting limits within SMZ's, some timber companies have employed their own harvest limits. For instance, MeadWestvaco Corporation restricts timber harvest to $50 \%$ of the basal area within SMZ's (Aaron Plaugher, Personal Communication). Despite varying SMZ harvest limits employed by timber companies and state BMP's, a review of the literature found no studies that actually quantify the impacts of different harvest limits in SMZ's on coldwater streams. The results of this research will help quantify the impacts of different harvest limits in SMZ's on coldwater streams and develop science-based recommendations for forest management and Best Management Practices (BMP) in coldwater streams. 
Streams in the $90 \%$ removal treatment had large increases in stream temperature $\left(3.1^{\mathrm{O}} \mathrm{C}\right)$ while $50 \%$ removal treatment streams had small increases in temperature $\left(0.6^{\mathrm{O}} \mathrm{C}\right)$ over the $500 \mathrm{~m}$ stream reach. However, it appears from the small observed increases in temperature within 50\% removal treatments that restricting harvest to $50 \%$ of the basal area within SMZ's is protective of coldwater streams. Kochenderfer et al., (1997) in studying West Virginia BMP guidelines concluded that removing approximately $44 \%$ of the basal area within a SMZ resulted in nonsignificant increases in stream temperatures, because the stream remained shaded by residual trees and understory shrubs growing along it. Increased removal of timber from SMZ's above the $50 \%$ threshold may result in increased stream temperatures creating marginal habitat for brook trout even if SMZ harvest is limited to less than $500 \mathrm{~m}$ of stream length. The United States Environmental Protection Agency recommends that mean weekly maximum water temperatures do not exceed $24^{\circ} \mathrm{C}$ for even one week in streams with populations of brook trout (EPA 1986). In our study, mean daily temperature only exceeded $20^{\circ} \mathrm{C}$ on one stream (Mitchell Lick) for a two day period. However Mitchell Lick did have maximum daily temperature exceed $24^{\circ} \mathrm{C}$ for several days, which may have resulted in movement of fish or physiological stress.

Streams that are warmed in clearings sometimes cool as they flow back under intact forest canopy during the daytime. This cooling minimizes the stream length impacted by warming and decrease the potential impacts of clear-cutting around headwater streams on downstream, fish-bearing reaches. Within the $100 \mathrm{~m}$ buffer zone we observed decreases in stream temperature. Previous studies of temperature recovery downstream of timber harvest showed large decreases in a relatively short downstream distance (McGurk 1989, Keith et al. 1998). Temperature recovery downstream of a harvest zone is important because a rapid 
decrease in temperature over a short distance can effectively limit the spatial impact of the harvest.

We found that timber harvest within SMZ's had some positive effect on fish as YOY and age $1+$ densities were greater in the removal section in both $50 \%$ and $90 \%$ removal streams during some portions of the year. We found decreases of age $1+$ trout during summer 2008 in $90 \%$ streams, which could be due to avoidance of the removal sections during increased summer stream temperatures. Or alternatively it could be that age $1+$ trout are consuming terrestrial invertebrates at this time of year and move into the sections with abundant terrestrial invertebrates (Utz and Hartman 2006, Sweka and Hartman 2008). The further decrease in age 1+ trout density from August to November 2008 in the $90 \%$ streams could also indicate decreased summer survival within these sections. We found that $50 \%$ removal sections did not have these large decreases in age 1+ fish from June to August 2008 and actually had increased in YOY in these sections during this time. We found that mean total length of YOY brook trout was greater in removal sections than reference sections of $50 \%$ removal streams during June, August, and November 2007, and August 2008, with no differences in 90\% removal streams. The $50 \%$ basal area removal of trees within an SMZ had minimal effects on brook trout and in some cases may be beneficial. We found that while $90 \%$ harvest may benefit brook trout during spring, these harvests may negatively affect brook trout during summer months.

Brook trout consumed a greater proportion of terrestrial invertebrates in reference sections than in removal sections during the study. Terrestrial invertebrates composed one-half of prey ingested by brook trout in reference streams during this study and one-third of the prey in removal sections. Terrestrial invertebrates composed nearly $75 \%$ of the biomass consumed in reference sections and around $35 \%$ of the biomass consumed in removal sections. 
Approximately $73 \%$ of the energy brook trout gained was derived from terrestrial invertebrates in the reference sections while derived $24 \%$ of their energy was from terrestrial invertebrates in the removal sections. Terrestrial invertebrates represented a greater proportion of the abundance, biomass and energy for brook trout in reference sites. Terrestrial invertebrate abundance, biomass and energy were slightly reduced in 50\% removal sections and were greatly reduced in 90\% removal sections. The observed reduction in terrestrial invertebrate consumption in removal sections may negatively impact brook trout growth and trout may not be able to compensate for this reduction by feeding solely on aquatic invertebrates (Sweka and Hartman 2008). The harvest of riparian timber may have an effect on brook trout energetics, especially during summer when brook trout are food limited. Based on the evidence from our study that brook trout receive an important portion of their food supply from terrestrial in-fall and that the magnitude of this input varies with the amount of riparian vegetation, suggests that there could be long-term changes in brook trout diet in areas with riparian timber harvest and should be considered in the management of streamside areas.

Of particular interest in this study and other studies of central Appalachian streams is the role that Lepidoptera appear to have in sustaining summer brook trout populations. During our study the proportion of Lepidoptera abundance, biomass and energy was significantly lower in both terrestrial pan traps and brook trout diets in both 50\% and 90\% removal sections compared to reference sections. Lepidoptera appear to play an important role in sustaining summer brook trout populations and the removal of riparian forest reduced Lepidoptera input to the streams. Lepidopterans are almost certainly important as a resource for maintaining brook trout populations as they provide a seasonally abundant food source during the summer. This suggests 
that harvest of riparian timber may have an effect on brook trout energetics, especially during summer.

Our results suggest that $50 \%$ basal area removal of trees within an SMZ has minimal effects on brook trout and in some cases may be beneficial. Our results also suggest that while $90 \%$ basal area harvest may benefit brook trout during spring, these harvests may negatively affect brook trout during summer months. Therefore we recommend that coldwater streams should have a minimum of 50 percent of the basal area retained within the SMZ. The short-term (year 1) increase and then subsequent decrease (year 2) in brook trout densities make it necessary to assess trends in brook trout populations over several years as there are several unknowns associated with the possible response to varying basal area removal. In addition, the apparent importance of terrestrial organisms in our study suggests that there could be long-term changes in brook trout diet in the removal sections and a potential long term shift in the feeding habits of brook trout, as riparian areas in the $90 \%$ removal sections may take 40 years or more to regenerate timber structure to the pre-cut levels. The long term reduction of terrestrial invertebrate availability to brook trout may result in decreased growth of Appalachian brook trout in these sections. Future work should investigate the long term $(5,10,15,20,25,30$ year) changes in trout density, benthic invertebrate productivity, and terrestrial invertebrate inputs associated with varying levels of timber harvest in these streams.

\section{Large Woody Debris additions}

The addition of large woody debris (LWD) had varying effects on stream channel morphology in the eight streams of this study. Stream sections with added LWD did create new pools in all of the streams, but there was no net increase in pool area following habitat 
manipulation. Channel structure in these headwater streams was extremely dynamic, with new pools being created by LWD, and other pools being lost. In addition, many of the pools created by LWD were temporary, they formed one year post-treatment and disappeared the following year. Sweka and Hartman (2006) found similar results in that pools created one year by LWD additions were often lost by the next year. Hilderbrand et al. (1997) also noted that in high gradient streams receiving LWD, some of the pools created by their LWD additions quickly reverted back to riffle habitat. Both Hilderbrand et al. (1997) and Sweka and Hartman (2006) concluded that it may take several years for added LWD to realize its potential to modify stream channel habitat. Although the LWD additions in the present study did not significantly increase the pool area in these streams, the LWD within the stream probably did serve some function. The massive addition of organic debris to the LWD streams had many channel and ecological effects. Larger pieces of LWD are more likely to become anchored on stream banks or trees along the stream. The slash protected the channel from solar radiation and also acted as thermal insulation, mitigating the impact from timber harvest. The hydraulic roughness provided by the leaves, twigs, and branches trapped fine sediment in the channels. In some streams, the channel became indistinct, and the water flowed through a matrix of mixed tree tops, logs, leaves and organic material. The inability of LWD additions to increase pool area may be due to the simple fact that the added LWD had not been in the streams long enough to become incorporated into the streambanks, and the majority of trees were felled across the stream channel and are hanging above the bankfull channel. The full potential of the added LWD to modify the stream channel morphology may not be realized for many more years.

In small streams, post-harvest wood covering the channel can mitigate the effects of riparian vegetation removal on water temperatures by providing shade (Collier et al 1997). We 
suspect that the addition of large woody debris and tree tops along with groundwater inflow played a significant role in mitigating the effect of tree removal in our study. In our study, the addition of LWD and tree tops to the stream added much needed shade to the stream especially in $90 \%$ removal sites. This added LWD may have tempered the effects of increased summer stream temperatures in the $90 \%$ removal streams, and should be considered a viable management technique in coldwater streams that have large canopy openings.

Current BMP's require that all logging debris be removed from streams during timber operations. Currently, felled tops must be pulled from the stream channel on all perennial and intermittent streams, as small logging debris can be harmful to the stream channel causing bank erosion and channel blockage (West Virginia Division of Forestry 2005). During our study we only had one location where channel blockage and erosion was an issue. On the LWD addition section of Rocky Run, there was a large debris dam created by the placement of logs and tree tops just before a bend in the stream. The debris dam created a large pool both upstream and downstream of the dam. An old skid road also crossed the creek in this location and no debris was placed on the skid road to prevent potential erosion. During high flows water began to back up and flow down the old skid road. Sometime during the spring of 2007, a large flood allowed Rocky Run to run down a nearby old skid road for approximately 50 m, carving a new channel until it rejoined the mainstem of the stream. After this channel was carved, approximately $1 / 3$ of the stream flowed down this skid road during normal baseflow conditions. This probably could have been avoided if logs and tree tops had also been placed on the skid road or if the debris dam had not been created near the skid road or curve in the channel. While, bank erosion and channel blockage is possible, careful addition of logs and tree tops to the stream under certain conditions will prevent the problems that have been associated with these practices. Based upon our 
observations and analysis of the data we recommend that logs and tree tops can be kept in perennial and intermittent streams under the following conditions: 1) No logs or tree tops placed on stream bends, due to potential channel meander. 2) Logs and tree tops should be placed in straight-aways in order to prevent channel meander. 3) Logs and tree tops should be placed in longer riffles or runs to encourage pool formation. 4) Logs and tree tops should be added at the rate of one debris dam per $25 \mathrm{~m}$ of stream. 5) Debris dams should be less than $1 \mathrm{~m}$ in height in order to facilitate movement of fish. 6) Logs and tree tops should not be added in areas where old skid or railroad grades cross the stream. 7) Logs and tree tops should not be placed in pool habitat as they may potentially fill in due to changes in stream morphology. 8) Logs and tree tops should not be added upstream (within $250 \mathrm{~m}$ ) of a bridge or culvert crossing. By following these recommendations on LWD input into streams, timber management activities can enhance instream habitat within Appalachian streams while at the same time preventing problems like bank erosion, culvert blockage, and channel meander than have been commonly associated with LWD inputs from timber operations.

\section{Canopy cover, basal area and slope}

It may be important to consider how percent canopy cover and percent basal area removal may interact in order to provide recommendations on SMZ timber harvest. Pre-harvest our streams had canopy closure between 90.0 and $97.3 \%$ along the SMZ. A review of the BMP's from some southern states found that these states suggest leaving 50-75\% canopy cover or 50 $\mathrm{ft}^{2} /$ acre basal area on perennial and coldwater streams. Canopy closure post-harvest in our 50\% treatment streams ranged from 74.9 to $87.6 \%$ in the treatment sections, while canopy closure in the $90 \%$ treatment streams ranged from 18.1 to $67.6 \%$ in treatment sections. Post-harvest 
canopy closure within the $50 \%$ treatments was within these southern states recommendations, while $90 \%$ treatments exceeded these recommendations. It may be important to consider preremoval canopy closure before allowing a 50\% basal area harvest, especially if pre-harvest canopy closure is less than the $90 \%$ found in our study streams. In this case, it would be suggested to leave $50 \%$ canopy cover along these coldwater streams.

While our research does help to propose recommendations for riparian timber harvest based upon the best available science, there are some possible limitations in the current study. The maximum area of harvest in each section of stream was approximately 1.5 hectares $(3.70$ acres) with a total maximum harvest area of 3 hectares ( 7.40 acres) overall. Harvests on MeadWestvaco timberland were typically restricted to an area less than 40 acres (Aaron Plaugher, personal communication). The maximum area harvested via clear-cut (90\% basal area removal) during this study could be considered a small harvest by industry standards (Shawn Grushecky, personal communication). However, it should be noted that not every stream section achieved maximum harvest in $90 \%$ removal streams due to possible problems with slope failure and other potential operational problems. Even with some $90 \%$ removal streams receiving less than maximum harvest we still found large increases in stream temperature along the stream gradient. A full harvest on these streams sections may have resulted in greater stream warming in these sections. We did not take temperature readings below the harvest sections on our study streams, thus it is unknown what effect increased stream temperature would have downstream of these cuts. It is entirely possible that there was cooling of stream temperatures as it flowed back into intact SMZ. Temperature recovery downstream of the harvest zones may be important to research because rapid decrease in temperature over a short distance may help to limit impact of upstream harvest. 
Our streams ranged from 1.95 to $3.28 \%$ slope over the length of the study sections. It is unknown how riparian timber harvest on higher gradient streams would affect brook trout and water quality. Steeper slopes along the stream have been shown to increase the speed of runoff and have more potential for soil erosion (Trimble and Sartz 1957, Swift 1986). West Virginia BMP's have no current timber management recommendations for areas of the SMZ where slopes increase in steepness. Some states have recognized this relationship between steep slopes and potential soil erosion and developed their SMZ buffer requirements according to slope gradients. North Carolina and Virginia's BMP manual states that steep slopes all need wider SMZs to protect water quality, but give no recommendations on width or what is considered steep (Virginia Department of Forestry 2002). The Canadian province of Ontario developed general recommendations for increasing SMZ width as percent slope increases (Ontario Ministry of Natural Resources 1988). Their baseline recommendations are for a no harvest SMZ of 8 m (27 feet) wide with 0-10\% slope, with the no harvest SMZ increasing to > $44 \mathrm{~m}$ (144 feet) when slopes exceed $60 \%$. Since, slope is an important factor influencing erosion and sedimentation, our recommendations for timber harvest may only apply for streams with similar slopes to our study streams $(\sim 2-3.3 \%)$, and more research may be needed to determine how slope and harvest may impact coldwater fisheries. 


\section{References}

Alabama Forestry Commission. 1993. Best management practices for forestry. Alabama Forestry Commission, Montgomery.

Boyle K. J., B. Roach, and D. G. Waddington. 1996. Net economic values for bass, trout and walleye fishing, deer, elk and moose hunting and wildlife watching: Addendum to the 1996 national survey of fishing, hunting and wildlife-associated recreation. U.S. Fish and Wildlife Service, Department of the Interior.

Childs, R. A. 2005. West Virginia Forests: Growing West Virginia's future. Bureau of Business and Economic Research, College of Business and Economics, West Virginia University, Morgantown.

Collier, K. J., B. R. Baillie, E. J. Bowman, N. J. Halliday, J. M. Quinn, and B. J. Smith. 1997. Is wood in streams a dammed nuisance? Water and Atmosphere 5:17-21.

Environmental Protection Agency. 1986. Water quality criteria. EPA 440/5-86-001. Office of Water Regulations and Standards, Washington, D. C.

Florida Division of Forestry. 2003. Silviculture best management practices. Florida Division of Forestry Tallahassee.

Georgia Forestry Commission. 1999. Best management practices for forestry. Georgia Forestry Commission, Macon.

Hilderbrand, R. H., A. D. Lemly, C. A. Dolloff, and K. L. Harpster. 1997. Effects of large woody debris placement on stream channels and benthic macroinvertebrates. Canadian Journal of Fisheries and Aquatic Sciences 54:931-939.

Keith, R. M., T. C. Bjornn, W. R. Meehan, N. J. Hetrick, and M. A. Brusven. 1998. Response of juvenile salmonids to riparian and instream cover modifications in small streams flowing through second-growth forests of southeast Alaska. Transactions of the American Fisheries Society 127:889-907.

Kentucky Department of Forestry. 1997. Field guide to best management practices for timber harvesting. Kentucky Department of Forestry, Lexington.

Kilgore, M. A., and C. R. Blinn. 2003. The financial cost to forest landowners who implement forest guidelines: an empirical assessment. Journal of Forestry 101:37-41.

Kochenderfer, J. N., P. J. Edwards, and F. Wood. 1997. Hydrologic impacts of logging an Appalachian watershed using West Virginia's best management practices. Northern Journal of Applied Forestry 14:207-218. 
LeDoux, C. B. 2006. Assessing the opportunity costs of implementing streamside management zone guidelines in eastern hardwood forests. Forest Products Journal 56:40-44.

Louisiana Department of Agriculture and Forestry. 1997. Recommended forestry best management practices. Louisiana Department of Agriculture and Forestry, Baton Rouge.

McGurk, B. J. 1989. Predicting stream temperature after riparian vegetation removal. Pages 157164 in Proceedings of the California riparian systems conference: Protection, management, and restoration for the 1990s. USDA Forest Service, General Techincal Report PSW-110, Davis, California.

Mississippi Forestry Commission. 2000. Best management practices for forestry. Mississippi Forestry Commission, Jackson.

North Carolina Division of Forest Resources. 1989. Forestry best management practices manual. North Carolina Division of Forest Resources, Raleigh.

Shaffer, R., and W. M. Aust. 1993. A cost/benefit comparison of voluntary and regulatory forestry BMP programs. in: Proceedings, 16th annual meeting of Council of Forest Engineering, September 8-11, 1993, Savannah, Georgia. Council of Forest Engineering, Corvallis, Oregon.

South Carolina Forestry Commission. 1994. Best management practices. South Carolina Forestry Commission, Columbia.

Sweka, J. A., and K. J. Hartman. 2006. Effects of large woody debris addition on stream habitat and brook trout populations in Appalachian streams. Hydrobiologia 559:363-378.

Sweka, J. A., and K. J. Hartman. 2008. Contribution of terrestrial invertebrates to yearly brook trout prey consumption and growth. Transactions of the American Fisheries Society $137: 224-235$.

Swift, L. W. 1986. Filter strip widths for Forest Roads in the southern Appalachians. Southern Journal of Applied Forestry 10:27-34.

Tennessee Department of Agriculture Division of Forestry. 2003. Guide to forestry best management practices. Tennessee Division of Forestry, Nashville.

Thornton, K. W., S. P. Holbrook, K. L. Stolte, and R. B. Landy. 2000. Effects of forest management practices on Mid-Atlantic streams. Environmental Monitoring and Assessment 63:31-41.

Trimble, G. R., and R. S. Sartz. 1957. How far from a stream should a logging road be located? Journal of Forestry 55:339-341. 
United States Fish and Wildlife Service. 1996. Department of the Interior, and U.S. Department of Commerce, Bureau of the Census. National Survey of Fishing, Hunting, and Wildlife-Associated Recreation.

Utz, R. M., and K. J. Hartman. 2006. Temporal and spatial variation in the energy intake of a brook trout (Salvelinus fontinalis) population in an Appalachian stream. Canadian Journal of Fisheries and Aquatic Sciences 63:2675-2686.

Virginia Department of Forestry. 2002. Forestry best management practices for water quality in Virginia. Virginia Department of Forestry, Charlottesville.

West Virginia Division of Forestry. 2005. West Virginia silvicultural best management practices for controlling soil erosion and sedimentation from logging operations. WVDOF-TR-053, Charleston.

Wilson M. A., and S. R. Carpenter. 1999. Economic valuation of freshwater ecosystem services in the United States: 1971-1997. Ecological Applications 9:772-783. 
Vita

\section{JONATHAN M. NILES}

\section{A. BIOGRAPHICAL INFORMATION:}

\section{Addresses}

West Virginia University

213 Percival Hall

Division of Forestry and Natural Resources

Morgantown, WV 26506-6125

349 Baldwin Street

Morgantown, WV 26505 jniles@mix.wvu.edu

office phone (304) 293-0041

cell. phone (304) 288-8879

fax (304) 293-2441

phone 304-288-8879

\section{Education}

Ph.D. Forest Resources Science: Fisheries and Wildlife Resources, August 2004-May 2010

West Virginia University (Successful defense December 22, 2009)

Dissertation title: Brook trout response to canopy and large woody debris manipulations in Appalachian streams.

Advisor: K.J. Hartman, Ph.D.

M.S. Fisheries and Wildlife Resources, August 2004, West Virginia University.

Thesis title: Larval Fish Use of Experimental Rock Structures in the Kanawha River, West Virginia.

Advisor: K.J. Hartman, Ph.D.

B.A. Biology, May 2000, St. Mary’s College of Maryland.

\section{Employment}

West Virginia University, University Fellow, 2009

West Virginia University, Research Assistant, 2002-2008

West Virginia University, Teaching Assistant, Biology, 2001-2002

Environmental Scientist, American Land Concepts, 2001

Natural Resource Biologist I, Maryland Department of Natural Resources, 2000

\section{B. PUBLICATIONS}

\section{Articles in refereed journals:}

Niles, J. M. and K. J. Hartman. (In Press) Temporal distribution and taxonomic composition differences of larval fish in a large navigable river: a comparison of artificial dike structures and natural habitat. River Research and Applications.

Niles, J. M. and K. J. Hartman. 2009. Larval fish use of artificial rock structures on a navigable river. North American Journal of Fisheries Management 29:1035-1045. 
Niles, J. M. and K. J. Hartman. 2007. Comparison of three larval fish gears to sample shallow water sites on a navigable river. North American Journal of Fisheries Management 27:1126-1138.

\section{Articles in Review:}

Niles, J. M., K. J. Hartman, and P. D. Keyser. (In Review) Short-term effects of beaver dam removal on brook Trout in an Appalachian headwater stream. Northeastern Naturalist.

Sweka, J. A., K. J. Hartman, and J. M. Niles. (In Review) Long-term effects of large woody debris addition on stream Habitat and Brook Trout populations. Journal of Fish and Wildlife Management.

\section{Articles in preparation:}

Niles, J. M., K. J. Hartman, and J. Studinski. The role of riparian timber harvest and large woody debris additions in structuring stream habitat and thermal regimes in central Appalachian streams.

Niles, J. M. and K. J. Hartman. The effect of riparian canopy removal and large woody debris additions on brook trout populations in central Appalachian streams

Niles, J. M. and K. J. Hartman. Terrestrial invertebrate inputs to Appalachian streams after riparian canopy removal and their importance to brook trout.

\section{Non-refereed Published Reports:}

Niles, J. M., and R.W. Paul. April 2000. A study of imperviousness in Hilton Run, St. Mary's County, Maryland and its impact on biotic integrity. For: Department of Biology, St. Mary’s College of Maryland, St. Mary’s City, MD.

\section{Published Abstracts:}

Niles, J. M and K. J. Hartman. 2007. Brook Trout Response to Canopy and Large Woody Debris Manipulations in Appalachian Streams. Proceedings of the Sixty-first Annual Conference of the Southeastern Association of Fish and Wildlife Agencies. 61:110.

Niles, J. M. A study of imperviousness in Hilton Run, St. Mary's County, Maryland and its impact on biotic integrity. In: Paul, R.W. and Tanner, C.E. 2002. The St. Mary's River Project: Preserving Maryland's Legacy, Final Report Year 2. Report to U.S. H.U.D.; Grant \# B-00-SP-MD-0450.

Niles, J. M. A study of imperviousness in Hilton Run, St. Mary's County, Maryland and its impact on biotic integrity. In: Paul, R.W. and Tanner, C.E. 2001. The St. Mary's River Project: Preserving Maryland's Legacy, Final Report Year 1. Report to U.S. EPA; Grant \# X-983090-01.

\section{PROFESSIONAL PRESENTATIONS}

\section{Invited:}

Niles, J. M. and K. J. Hartman. 2009. Riparian timber harvest using BMP's as a potential management tool for brook trout habitat enhancement in Appalachian headwater streams. Headwater Streams III Symposium, Annual meeting of the American Fisheries Society, Nashville, Tennessee, August 31-September 4, 2009. 
Niles, J. M., K. J. Hartman, and B. K. Keplinger. 2008. Appalachian brook trout and their dietary analysis and their linkage to riparian zone manipulation. Headwater Streams Symposium, Annual meeting of the American Fisheries Society, Ottawa, Ontario, Canada, August 17-21, 2008

Niles, J. M. and K. J. Hartman. 2007. Role of geology, habitat and landscape features in structuring brook trout populations in headwater streams. Headwaters at the Nexus Symposia, Annual meeting of the American Fisheries Society, San Francisco, California, September 2-7, 2007.

\section{Other presentations:}

Niles, J. M. and K. J. Hartman. 2008. Brook trout response to canopy and large woody debris manipulations in Appalachian Streams. Annual meeting of the Southern Division of the American Fisheries Society, Wheeling, West Virginia, March 1-2, 2008.

Niles, J. M. and K. J. Hartman. 2007. Brook trout response to canopy and large woody debris manipulations in Appalachian Streams. Annual meeting of the Southeastern Association of Fish and Wildlife Agencies, Charleston, West Virginia, October 21-24, 2007.

Niles, J. M. and K. J. Hartman. 2005. Potential effects of canopy removal and large woody debris additions on brook trout. Annual meeting of the West Virginia Chapter of the American Fisheries Society. Flatwoods, West Virginia. February, 2005.

Niles, J. M. and K. J. Hartman. 2004. Larval Fish Use of Experimental Rock Structures in the Kanawha River, West Virginia. Annual meeting of the American Fisheries Society, Madison, Wisconsin, September, 2004.

Niles, J. M. and K. J. Hartman. 2004. Comparison of three larval fish gears to sample shallow water sites on a navigable river. Annual meeting of the West Virginia Chapter of the American Fisheries Society, Clarksburg, West Virginia, March, 2004.

Niles, J. M. and K. J. Hartman. 2003. Larval Fish Use of Experimental Rock Structures in the Kanawha River, West Virginia. Annual meeting of the West Virginia Chapter of the American Fisheries Society, Morgantown, West Virginia, April 24, 2003.

Niles, J. M. and K. J. Hartman. 2001. Rock Structures as Larval Fish Habitat in the Kanawha River, West Virginia. Annual symposium of the Wildlife Habitat Council, Washington D.C., November, 2001.

\section{Posters:}

Niles, J. M. and K. J. Hartman. 2007. Removal of a beaver pond and its effects on brook trout. Annual meeting of the West Virginia Chapter of the American Fisheries Society, Morgantown, West Virginia, February, 2007.

Niles, J. M. and K. J. Hartman. 2006. Removal of a beaver pond and its effects on brook trout. Annual meeting of the American Fisheries Society, Lake Placid, New York, September, 2006.

Niles, J. M. and K. J. Hartman. 2001. Rock Structures as Larval Fish Habitat in the Kanawha River, West Virginia. Annual symposium of the Wildlife Habitat Council, Washington D.C., November, 2001.

\section{Organized sessions:}

Symposia organizer, AFS National Meeting 2009, Headwater Streams III 


\section{TEACHING}

\section{Courses Taught}

Fall 2009

Environmental Biology, BIOL 106, West Virginia University, 12 students

Summer 2009

Marine Ecology, WMAN 314, West Virginia University, 12 students

Spring 2008

Wildlife Ecosystem Ecology, WMAN 313, West Virginia University, 42 students

Summer 2007

Marine Ecology, WMAN 493, West Virginia University, 11 students

Spring 2002

Introduction to Biology, BIOL 103, West Virginia University, 4 sections, 24 students

Fall 2001

Introduction to Biology, BIOL 103, West Virginia University, 4 sections, 24 students

Spring 2000

Limnology, BIOL 432, Teaching Assistant, St. Mary’s College of Maryland, 16 students

\section{Classes Taken}

Fish Ecology

Spatial Analysis for Resource Management

Environmental Regulations and Laws

Fisheries Management

Wildlife and Fisheries Seminar

Fisheries Techniques

Problems in Geomorphology

Conservation Biology

Human Dimensions-Natural Resource Mgt

Advanced Wildlife Population Ecology

Non-Parametric Statistics
Statistical Methods I

Statistical Methods II

Quantitative Ecology

Advanced Ichthyology

Limnology

Fish Physiology

Restoration Ecology

Advanced Forest Ecology

Critical Review-Fisheries

Applied Aquatic Entomology

\section{E. RESEARCH}

\section{Projects}

Brook trout response to canopy and large woody debris manipulations in Appalachian streams.

Ph.D. Dissertation. Wildlife and Fisheries Resources, West Virginia University, Morgantown, West Virginia. 2005-2009. 
Role of geology, habitat and landscape features in structuring brook trout populations in headwater streams. Long-term research project. Wildlife and Fisheries Resources, West Virginia University, Morgantown, West Virginia. 2002-2009

Larval Fish Use of Experimental Rock Structures in the Kanawha River, West Virginia. Master's Thesis. Wildlife and Fisheries Resources, West Virginia University, Morgantown, West Virginia. 2001-2004

A study of imperviousness in Hilton Run, St. Mary's County, Maryland and its impact on biotic integrity. St. Mary's College of MD Senior Project. Department of Biology, St. Mary's College of Maryland, St. Mary's City, Maryland. Research Conducted for: U.S. EPA; Grant \# X-983090-01. 1999-2000

\section{$\underline{\text { Skills }}$}

Lab skills: Benthic macroinvertebrate identification, larval fish identification, specimen preservation, fish identification, fish diet identification, captive-rearing of fish, calibration of water quality instruments.

Computer Skills: SAS TM, JMP TM, Program Mark, MS Word, MS Excel, MS Powerpoint, MS Access, ArcView, ArcInfo, and ArcGIS TM,.

Field skills: Powerboat operation, BVET Habitat measurements, backpack electroshocking, boat electroshocking, gastric lavage, boat towing and trailering, radio telemetry, water quality measurements, seining, trawling and trapping techniques, larval fish sampling, EPA Rapid Bioassement Protocols.

\section{Training}

American Red Cross CPR Certification, January 2009

American Red Cross First Aid Certification, January 2009

U.S. DOI Motor Boat Operator Certification Course, Spring 2002

U.S. DOI Electroshocking Certification, Fall 2001

\section{F. HONORS AND AWARDS}

West Virginia University Dissertation Fellowship, August 2009.

Skinner Memorial Travel Award, American Fisheries Society, August, 2008.

Hoyt Teaching Fellowship, Academic year 2007-2008, Division of Forestry and Natural

Resources, West Virginia University

Robert E. Stitzel Graduate Student Support Award, August, 2007, Davis College of Agriculture, Forestry and Consumer Sciences. West Virginia University

Wildlife Habitat Council $13^{\text {th }}$ Annual Symposium Scholarship Winner, November, 2001 Eagle Scout, Boy Scouts of America, 1994 


\section{G. PROFESSIONAL MEMBERSHIPS}

American Fisheries Society

- 2008 Best Paper Committee, North American Journal of Fisheries Management

- 2008 Best Paper Committee, Transactions of the American Fisheries Society

- 2007 Best Paper Committee, Transactions of the American Fisheries Society

American Fisheries Society Education Section

American Fisheries Society Student Subsection of Education Section

- Southern Division Representative, 2007-2008

West Virginia Chapter of the American Fisheries Society

West Virginia University Chapter of the American Fisheries Society

- Treasurer, 2004-2008 


\section{REFERENCES}

Kyle J. Hartman, Ph.D., Professor, Division of Forestry and Natural Resources, West Virginia University, Morgantown, West Virginia 26506-6125, 304-293-4797, hartman@wvu.edu (Master's and Ph.D. Advisor)

Patricia Mazik, Ph.D., Adjunct Associate Professor, Unit Leader of WV Cooperative Fish and Wildlife and Fisheries Research Unit, West Virginia University, Morgantown, West Virginia 26506-6125, 304-293-4943 pmazik@wvu.edu

J. Todd Petty, Ph.D., Associate Professor, Division of Forestry and Natural Resources, West Virginia University, Morgantown, West Virginia 26506-6125, 304-293-2278, jtpetty@mail.wvu.edu 